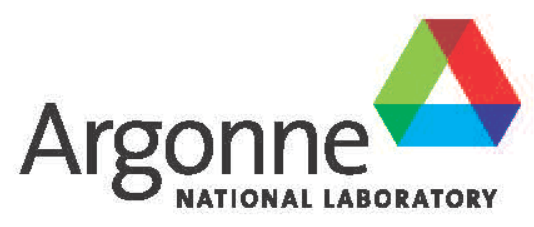

ANL/ESD/12-2

NATIONAL LABORATORY

\title{
Updated Greenhouse Gas and Criteria Air Pollutant Emission Factors and Their Probability Distribution Functions for Electric Generating Units
}

Energy Systems Division 
About Argonne National Laboratory

Argonne is a U.S. Department of Energy laboratory managed by UChicago Argonne, LLC under contract DE-AC02-06CH11357. The Laboratory's main facility is outside Chicago, at 9700 South Cass Avenue, Argonne, Illinois 60439. For information about Argonne and its pioneering science and technology programs, see www.anl.gov.

\section{Availability of This Report}

This report is available, at no cost, at http://www.osti.gov/bridge. It is also available

on paper to the U.S. Department of Energy and its contractors, for a processing fee, from:

U.S. Department of Energy

Office of Scientific and Technical Information

P.O. Box 62

Oak Ridge, TN 37831-0062

phone (865) 576-8401

fax (865) $576-5728$

reports@adonis.osti.gov

\section{Disclaimer}

This report was prepared as an account of work sponsored by an agency of the United States Government. Neither the United States Government nor any agency thereof, nor UChicago Argonne, LLC, nor any of their employees or officers, makes any warranty, express or implied, or assumes any legal liability or responsibility for the accuracy, completeness, or usefulness of any information, apparatus, product, or process disclosed, or represents that its use would not infringe privately owned rights. Reference herein to any specific commercial product, process, or service by trade name, trademark, manufacturer, or otherwise, does not necessarily constitute or imply its endorsement, recommendation, or favoring by the United States Government or any agency thereof. The views and opinions of document authors expressed herein do not necessarily state or reflect those of the United States Government or any agency thereof Argonne National Laboratory, or UChicago Argonne, LLC. 


\section{Updated Greenhouse Gas and Criteria} Air Pollutant Emission Factors and Their Probability Distribution Functions for Electric Generating Units

by

H. Cai, M. Wang, A. Elgowainy, and J. Han

Energy Systems Division, Argonne National Laboratory

May 2012 



\section{CONTENTS}

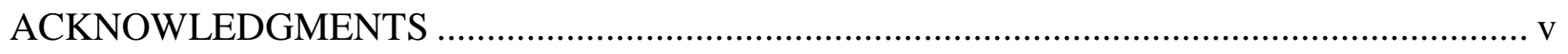

ACRONYMS AND ABBREVIATIONS ……………........................................................ vi

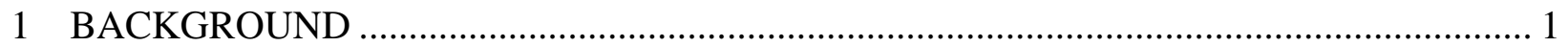

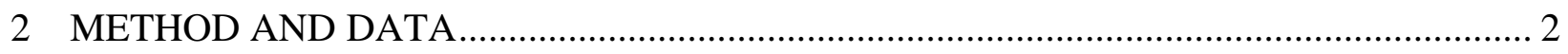

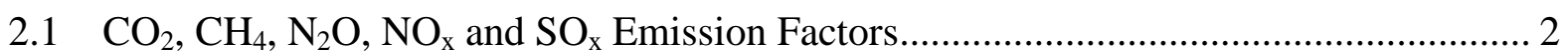

2.2 CO, VOC, $\mathrm{PM}_{10}$ and $\mathrm{PM}_{2.5}$ Emission Factors .............................................................. 6

2.3 Sulfur Contents and Ash Contents of Various Fuels by State ....................................... 21

2.4 Efficiencies ................................................................................................................. 24

2.5 Probability Distribution Functions of GHG and CAP Emission Factors and

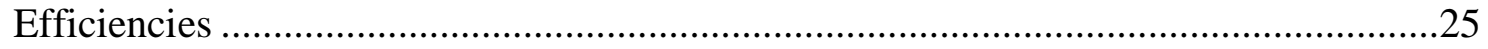

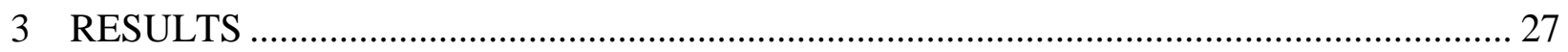

3.1 Data Quality Evaluation............................................................................................ 27

3.1.1 Detection of Outliers........................................................................................ 27

3.1.2 Comparison of GHG and CAP Emissions with EPA's NEI Data ...................... 27

3.1.3 Carbon Intensities by Fuel Type .................................................................... 29

3.2 National Average GHG and CAP Emission Factors and Efficiencies by Fuel Type and Generation Technology .........................................................................................30

3.3 Regional GHG and CAP Emission Factors and Efficiencies by Fuel Type and Generation Technology............................................................................................ 34

3.4 GHG and CAP Emission Factors and Efficiencies by Fuel Type and Generation

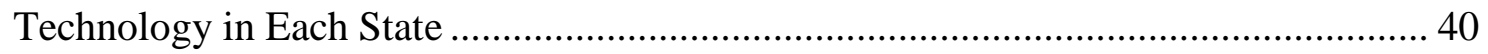

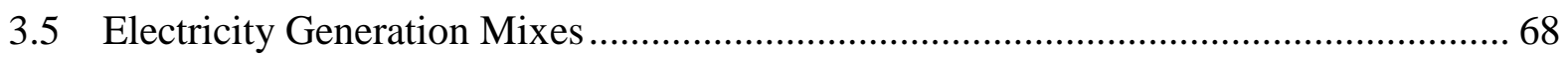

3.6 Electricity Transmission and Distribution Loss......................................................... 72

3.7 Probability Distribution Functions of GHG and CAP Emission Factors and Energy Efficiencies by Fuel Type and Combustion Technology of EGUs ............................... 74

3.8 Projection of generation mix, efficiency, Combustion technology share, and emission factors

3.9 Life-cycle Energy Use, GHG and CAP Emissions of Selected Vehicle/Fuel Systems

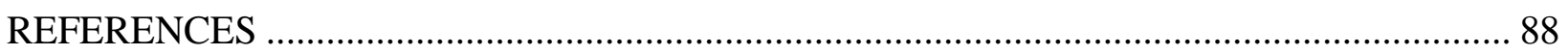

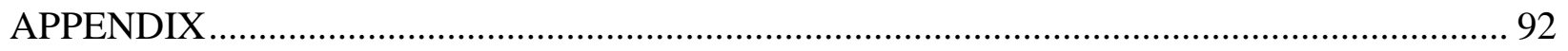




\section{FIGURES}

1 NERC region representational map from eGRID 2010 (EPA, 2011a).

2 Differences in energy use, GHG emissions, and CAP emissions per kWh electricity generated found in the present study, relative to those in GREET 1_2011, for electricity generation only and the full fuel cycle of the power plant.

3 Life-cycle (a) GHG; (b) VOC; (c) CO; (d) $\mathrm{NO}_{x}$; (e) $\mathrm{SO}_{\mathrm{x}}$; (f) $\mathrm{PM}_{10}$; and (g) $\mathrm{PM}_{2.5}$ emissions of selected vehicle/fuel systems with updated characterization of electricity generation module in GREET 1_2011. The red and purple error bars denote the standard deviations of the WTP and PTW emissions based on multiple stochastic simulations.

A1 Best-fit CDFs of electricity-generation-weighted GHG and CAP emission factors for coal-fired boilers. 103

A2 Best-fit CDFs of electricity-generation-weighted GHG and CAP emission factors for natural gas-fired boilers.

A3 Best-fit CDFs of electricity-generation-weighted GHG and CAP emission factors for natural gas-fired combustion turbines.

A4 Best-fit CDFs of electricity-generation-weighted GHG and CAP emission factors for natural gas-fired combined-cycle plants.

A5 Best-fit CDFs of electricity-generation-weighted GHG and CAP emission factors for natural gas-fired internal combustion engines.

A6 Best-fit CDFs of electricity-generation-weighted GHG and CAP emission factors for oil-fired boilers.

A7 Best-fit CDFs of electricity-generation-weighted GHG and CAP emission factors for oil-fired combustion turbines.

A8 Best-fit CDFs of electricity-generation-weighted GHG and CAP emission factors for oil-fired internal combustion engines.

A9 Best-fit CDFs of electricity-generation-weighted GHG and CAP emission factors for biomass-fired boilers.

A10 Best-fit CDFs of electricity-generation-weighted energy conversion efficiencies for coal-, natural gas-, oil- and biomass-fired boilers, combustion turbines, combined-cycle plants and internal combustion engines. 


\section{TABLES}

1 The number and electricity generation share of CHP and non-CHP facilities, and basic characteristics of EGUs by fuel type ...............................................................

2 CO emission factors of EGUs by fuel type, combustion technology, boiler bottom and firing type, and emission control technology.....

3 VOC emission factors of EGUs by fuel type, combustion technology, boiler bottom and firing type, and emission control technology

$4 \quad \mathrm{PM}_{10}$ emission factors of EGUs by fuel type, combustion technology, boiler bottom and firing type, and emission control technology

$5 \quad \mathrm{PM}_{2.5}$ emission factors of EGUs by fuel type, combustion technology, boiler bottom and firing type, and emission control technology.....

6 Sulfur contents (weight \%) of various fuels on an as-received basis in each state in year 2007.

7 Ash contents (weight \%) of various fuels on an as-received basis in each state in year 2007.

$8 \quad \frac{L H V_{f}}{H H V_{f}}$ ratios, on an as-received basis, of various fuels burned by EGUs.............................25

$9 \quad$ Number of outliers detected by fuel type and combustion technology ................................27

10 Comparison of total GHG and CAP emissions (thousand tons) calculated in the present study for the electric power sector with EPA's NEI data for the year 2007 .............28

11 Percentage of CI outliers detected by fuel type and generation technology ..........................30

12 GHG and CAP emission factors ( $\mathrm{g} / \mathrm{kWh}$ ) by fuel subtype and combustion technology for the electricity power sector in the U.S.

13 GHG and CAP emission factors ( $\mathrm{g} / \mathrm{kWh}$ ) by fuel type and combustion technology for the electricity power sector in the U.S.

14 GHG and CAP emission factors ( $\mathrm{g} / \mathrm{kWh}$ ), efficiencies, and combustion technology shares by NERC region......................................................................................................36

15 GHG and CAP emission factors and efficiencies in each state ...........................................41

16 Nationally averaged electricity generation mix (\%) ..........................................................68

17 Electricity generation mixes (\%) by NERC region based on eGRID ....................................69

18 Electricity generation mixes (\%) by state based on eGRID ..............................................70

19 Electricity T\&D gross grid loss factors (\%) on a state and national average basis ...............72

20 Probability distribution functions of energy efficiency, GHG and CAP emission factors by fuel type and combustion technology of EGUs 


\section{TABLES (CONT.)}

A1 $\mathrm{NO}_{\mathrm{x}}$ emission factors of EGUs by fuel type, combustion technology, firing type and emission control technology …………………………................................................. 93

A2 $\mathrm{SO}_{\mathrm{x}}$ emission factors of EGUs by fuel type, combustion technology, firing type and emission control technology 


\section{ACKNOWLEDGMENTS}

This study was supported by the Office of Biomass Program, Vehicle Technology Program, Hydrogen and Fuel Cells Program and Geothermal Technologies Program in the U.S. Department of Energy, Office of Energy Efficiency and Renewable Energy, under Contract DE-AC02-06CH11357. We are grateful to Dr. Susy Rothschild of TranSystems for helping to clarify the emissions data in the eGRID database provided by the U.S. Environmental Protection Agency. 


\section{ACRONYMS AND ABBREVIATIONS}

\begin{tabular}{|c|c|}
\hline $\mathrm{AB}$ & agricultural byproduct \\
\hline $\mathrm{AEO}$ & Annual Energy Outlook \\
\hline ARPD & Acid Rain Program Dataset \\
\hline $\mathrm{BEV}$ & battery-powered electric vehicle \\
\hline $\mathrm{BF}$ & biased firing \\
\hline BFG & blast furnace gas \\
\hline BIT & bituminous coal \\
\hline BLQ & black liquor \\
\hline BLR & boilers \\
\hline BOOS & burners-out-of-service \\
\hline CAP & criteria air pollutant \\
\hline CI & carbon intensity \\
\hline CC & combined cycle \\
\hline $\mathrm{CH}_{4}$ & methane \\
\hline $\mathrm{CHP}$ & combined heat and power \\
\hline $\mathrm{CO}$ & carbon monoxide \\
\hline $\mathrm{CO}_{2}$ & carbon dioxide \\
\hline Com.Opt. & combustion optimization \\
\hline CPM & condensable particulate matter \\
\hline CT & combustion turbines \\
\hline DFO & distillate fuel oil \\
\hline DG & digester gas \\
\hline eGRID & Emissions \& Generation Resource Integrated Database \\
\hline EGU & electric generating unit \\
\hline EIA & U.S. Energy Information Administration \\
\hline EPA & U.S. Environmental Protection Agency \\
\hline EPA/CAMD & EPA’s Clean Air Markets Division \\
\hline ESP & electrostatic precipitator \\
\hline FBC & fluidized bed combustion \\
\hline FGD & flue gas desulfurization \\
\hline FGR & flue gas recirculation \\
\hline FPM & filterable particulate matter \\
\hline GEO & geothermal energy \\
\hline GHG & greenhouse gas \\
\hline GREET & $\begin{array}{l}\text { Greenhouse Gases, Regulated Emissions, and Energy Use in Transportation } \\
\text { Model }\end{array}$ \\
\hline
\end{tabular}




\begin{tabular}{|c|c|}
\hline HHV & higher heating value \\
\hline ICE & internal combustion engines \\
\hline IGCC & integrated gasification combined cycle \\
\hline $\mathrm{JF}$ & jet fuel \\
\hline KER & kerosene \\
\hline $\mathrm{lb}$ & pound \\
\hline LEA & low excess air \\
\hline LFG & landfill gas \\
\hline LHV & lower heating value \\
\hline LIG & lignite coal \\
\hline LNB & low nitrogen burners \\
\hline MSB & biomass component of municipal solid waste \\
\hline $\mathrm{N}_{2} \mathrm{O}$ & nitrous oxide \\
\hline NEG & net electricity generated \\
\hline NEI & National Emission Inventory \\
\hline NERC & North American Electric Reliability Council \\
\hline NG & natural gas \\
\hline NGCC & natural gas combined cycle \\
\hline $\mathrm{NO}_{\mathrm{x}}$ & nitrogen oxides \\
\hline NSPS & New Source Performance Standards \\
\hline OBL & other biomass liquid \\
\hline OBS & other biomass solids \\
\hline OFA & overfire air \\
\hline OG & other gases \\
\hline OTH & other unknown \\
\hline PC & pulverized coal \\
\hline PDF & probability distribution function \\
\hline PetCoke & petroleum coke \\
\hline PHEV & plug-in hybrid electric vehicle \\
\hline $\mathrm{PM}_{2.5}$ & particulate matter up to 2.5 micrometers in size \\
\hline PM10 & particulate matter up to 10 micrometers in size \\
\hline PTW & pump-to-wheels \\
\hline PUR & purchased steam \\
\hline RFO & residual fuel oil \\
\hline $\mathrm{SC}$ & syncoal \\
\hline Scf & one cubic foot of volume at $60^{\circ} \mathrm{F}$ and $101.325 \mathrm{kPa}$ of pressure \\
\hline SCR & selective catalytic reduction \\
\hline SNCR & selective noncatalytic reduction \\
\hline
\end{tabular}




$\begin{array}{ll}\text { SO }_{\mathrm{x}} & \begin{array}{l}\text { sulfur oxides } \\ \text { SUB }\end{array} \\ \text { SUN } & \begin{array}{l}\text { subbituminous coal } \\ \text { solar energy }\end{array} \\ \text { T\&D } & \begin{array}{l}\text { transmission and distribution } \\ \text { tire-derived fuel }\end{array} \\ \text { TDF } & \text { volatile organic compounds } \\ \text { VOC } & \text { hydropower } \\ \text { WAT } & \text { waste coal } \\ \text { WC } & \text { woody biomass liquid } \\ \text { WDL } & \text { woody biomass solid } \\ \text { WDS } & \text { Web version of EPA's Factor Information Retrieval Data System } \\ \text { WebFIRE } & \text { waste heat } \\ \text { WH } & \text { water injection } \\ \text { WI } & \text { wind power } \\ \text { WND } & \text { waste oil } \\ \text { WO } & \text { well-to-wheels } \\ \text { WTW } & \text { well-to-pump } \\ \text { WTP } & \end{array}$




\section{UPDATED GREENHOUSE GAS AND CRITERIA AIR POLLUTANT EMISSION FACTORS AND THEIR PROBABILITY DISTRIBUTION FUNCTIONS FOR ELECTRIC GENERATING UNITS}

\section{BACKGROUND}

Greenhouse gas $\left(\mathrm{CO}_{2}, \mathrm{CH}_{4}\right.$ and $\mathrm{N}_{2} \mathrm{O}$, hereinafter $\left.\mathrm{GHG}\right)$ and criteria air pollutant (CO, $\mathrm{NO}_{\mathrm{x}}$, VOC, $\mathrm{PM}_{10}, \mathrm{PM}_{2.5}$ and $\mathrm{SO}_{\mathrm{x}}$, hereinafter CAP) emission factors for various types of power plants burning various fuels with different technologies are important upstream parameters for estimating life-cycle emissions associated with alternative vehicle/fuel systems in the transportation sector, especially electric vehicles. The emission factors are typically expressed in grams of GHG or CAP per kWh of electricity generated by a specific power generation technology. This document describes our approach for updating and expanding GHG and CAP emission factors in the GREET (Greenhouse Gases, Regulated Emissions, and Energy Use in Transportation) model developed at Argonne National Laboratory (see Wang 1999 and the GREET website at http://greet.es.anl.gov/main) for various power generation technologies. These GHG and CAP emissions are used to estimate the impact of electricity use by stationary and transportation applications on their fuel-cycle emissions. The electricity generation mixes and the fuel shares attributable to various combustion technologies at the national, regional and state levels are also updated in this document. The energy conversion efficiencies of electric generating units (EGUs) by fuel type and combustion technology are calculated on the basis of the lower heating values of each fuel, to be consistent with the basis used in GREET for transportation fuels. On the basis of the updated GHG and CAP emission factors and energy efficiencies of EGUs, the probability distribution functions (PDFs), which are functions that describe the relative likelihood for the emission factors and energy efficiencies as random variables to take on a given value by the integral of their own probability distributions, are updated using best-fit statistical curves to characterize the uncertainties associated with GHG and CAP emissions in life-cycle modeling with GREET. 


\section{METHOD AND DATA}

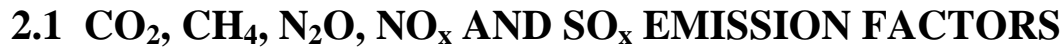

GHG and CAP emission factors by fuel type and combustion technology are required to perform life-cycle analyses using GREET. On the basis of the recent release of the Emissions \& Generation Resource Integrated Database, known as eGRID ${ }^{1}$ (EPA, 2011a), which contains comprehensive unit-level emission data and plant performance data like the heat input and electricity generation for year 2007, we calculate the $\mathrm{CO}_{2}, \mathrm{CH}_{4}, \mathrm{~N}_{2} \mathrm{O}, \mathrm{NO}_{\mathrm{x}}$ and $\mathrm{SO}_{\mathrm{x}}$ emission factors for each plant in the power generation sector. The version that we used, eGRID2010, provided the best available and most recent (2007) comprehensive data to meet our study objectives when this study began. However, eGRID2012, which incorporates the 2009 dataset, has just been released. Therefore, we are aware that we may have missed some recent trends in the evolution of the combustion technology for each type of power plant, which will eventually result in variations in their GHG and CAP emission factors. This assumption will be validated in a follow-up study using the latest available data from EIA and EPA, in comparison with the 2007 data addressed in this report.

The emissions of $\mathrm{CO}_{2}, \mathrm{CH}_{4}, \mathrm{~N}_{2} \mathrm{O}, \mathrm{NO}_{\mathrm{x}}$ and $\mathrm{SO}_{\mathrm{x}}$ in eGRID are based on data from a variety of sources, but its primary source for $\mathrm{CO}_{2}, \mathrm{SO}_{\mathrm{x}}$, and $\mathrm{NO}_{\mathrm{x}}$ emissions is the unit-level data from the Clean Air Markets Division (EPA/CAMD) (EPA, 2007a; Pechan, 2010a). If any of the emissions data are not reported, which is the case for 1076 out of 5172 EGUs, the emissions are estimated by eGRID as follows: $\mathrm{CO}_{2}$ emission factors are estimated using fuel consumption data from EIA-923 (EIA, 2007a), fuel carbon intensity, and the fraction of carbon oxidized to $\mathrm{CO}_{2}$ (a uniform oxidation fraction of 1 is used for all fossil fuels); $\mathrm{SO}_{\mathrm{x}}$ emission factors are estimated using fuel consumption data from EIA-923, EPA-approved uncontrolled-emission factors (Pechan, 2010b) are based on EPA's AP-42 emission factors (EPA, 2004), sulfur content, and control efficiencies, if available; and $\mathrm{NO}_{\mathrm{x}}$ emission factors for steam prime movers are estimated using fuel consumption data from EIA-923 and EPA-approved uncontrolled emissions factors for steam prime movers. For combined-cycle plants, turbines and internal combustion engines, $\mathrm{NO}_{\mathrm{x}}$ emission factors are developed on the basis of the prime mover technology, size, and location, and using data from the EPA Reasonably Available Control Technology/Best Available Control Technology/Lowest Achievable Emission Rate Clearinghouse (EPA, 2010a). The term "prime mover" refers to the machine (e.g., engine, turbine, water wheel) that drives the electric generator in the power plant.

In this work, the averaged $\mathrm{CO}_{2}, \mathrm{CH}_{4}, \mathrm{~N}_{2} \mathrm{O}, \mathrm{NO}_{\mathrm{x}}$ and $\mathrm{SO}_{\mathrm{x}}$ emission factors by fuel type and combustion technology are calculated by dividing the annual total emissions by the annual total net electricity generated (NEG) from that technology, as shown in Equation (1). The NEG in this

1 A comprehensive emission inventory of the electric power sector in the U.S. 
report refers to the generated electricity supplied to the grid, i.e., electricity directly consumed by EGUs is excluded.

$$
E F_{p, f, c t}=\frac{\sum_{i} \text { Emission }_{p, f, c t, i}}{\sum_{i} N E G_{f, c t, i}}
$$

where
$E F_{p, f, c t}$
(expressed in $\mathrm{g} / \mathrm{kWh}$ ) is the averaged emission factor of a GHG species or pollutant $p$ (e.g., $\mathrm{NO}_{\mathrm{x}}$ or $\mathrm{SO}_{\mathrm{x}}$ ) emitted by all power plants burning fuel $f$ using combustion technology $c t$;
Emission $_{p, f, c t, i}$ (expressed in grams) is the emissions of a GHG species or pollutant $p$ from power plant $i$ burning fuel $f$ using combustion technology $c t$; and
$N E G_{f, c t, i} \quad$ (expressed in $\mathrm{kWh}$ ) is the net electricity generated by power plant $i$ burning fuel $f$ using combustion technology $c t$.

To obtain Emission $_{p, f, c t, i}$, we first sort the plants in eGRID by fuel type based on the primary fuel type indicated by eGRID. This report explicitly updates the GHG and CAP emission factors for use in GREET on the basis of a total of 3394 combustion-based EGUs fired by four major fuel types: (1) coal, including the subtypes of bituminous coal (BIT), subbituminous coal (SUB), lignite (LIG), syncoal ${ }^{2}$ (SC), waste coal ${ }^{3}$ (WC), petroleum coke (PetCoke) and tire-derived fuel (TDF); (2) natural gas (NG), including the subtypes of NG, landfill gas (LFG), blast furnace gas (BFG), digester gas (DG), other gases (OG), and other unknown (OTH); (3) oil, including the subtypes of residual fuel oil (RFO), distillate fuel oil (DFO), jet fuel (JF), kerosene (KER), and waste oil (WO); and (4) biomass, including the subtypes of woody biomass solid (WDS), woody biomass liquid (WDL), black liquor (BLQ), agricultural byproduct (AB), biomass component of municipal solid waste (MSB), other biomass solid (OBS), and other biomass liquid (OBL). These combustion-based EGUs accounted for $75.0 \%$ of the total net electricity generated in the U.S., while 60 nuclear-power EGUs and 1718 renewable-power EGUs, including solar energy (SUN), hydropower (WAT), wind (WND), geothermal (GEO) and waste heat (WH), account for another $18.0 \%$ and $7.0 \%$ of the national generation, respectively.

While most power plants employ a single fuel type, a small percentage of power plants burn multiple fuel types. For multiple-fuel-fired plants, the primary fuel type employed by the prime mover with the largest nameplate capacity is recognized as the primary fuel type for that plant. Multiple-fuel-fired plants with the primary fuel types BIT, SUB, NG and DFO represent 6.5\%, $4.3 \%, 5.4 \%$ and $4.2 \%$, respectively, of the total. Aggregating the different fuel types under one

2 Syncoal includes briquettes, pellets, or extrusions, which are formed by binding materials or by processes that recycle materials. Syncoal has reduced sulfur and ash contents and increased heating value.

3 Waste coal includes anthracite culm, bituminous gob, fine coal and lignite waste. 
primary fuel type leads to a small error that is due to the difference in fuel properties and their combustion characteristics. We noticed that a few plants in eGRID, i.e., plants with DOE/EIA Office of the Regulatory Information System PLant (ORISPL) codes 30, 1225, 2390, 10437, 50241 and 54406, show inconsistent plant-level and generator-level primary fuel types. We made corrections to these minor discrepancies in eGRID and identified the true primary fuel types of these plants through personal communication with S. Rothschild (2012).

Next, we sort plants of the same fuel type by combustion technology, using information on the prime mover type of each generator within each power plant as provided in eGRID. For example, natural gas is used in power plants employing various prime mover technologies such as steam turbines, gas turbines, or both. Since many plants have multiple generators driven by different prime mover types, the prime mover type of the generators whose summed capacities represent the largest fraction of the entire capacity of a power plant is recognized as the prime mover type of that plant. For these plants, the $N E G_{f, c t, i}$ is determined by the annual electricity generation of power plant $i$ burning fuel type $f$ with the combustion technology $c t$ that defines the prime mover type of that plant.

A few combustion-based power plants with zero heat inputs or zero emissions and NEG that is a very small fraction of their nameplate capacities, which account for $0.53 \%$ of the national total NEG, are excluded from the calculation of GHG and CAP emission factors, since they are not representative of typical emission characteristics of EGUs. EGUs employing boilers, combustion turbines or engines with efficiency higher than $45 \%$, and combined-cycle plants with efficiency higher than $60 \%$, are regarded as unrealistic for current non-CHP ${ }^{4}$ efficiency levels (EVA, 2007; Bellman et al., 2007; Ishikawa et al., 2008), and are therefore excluded. Moreover, EGUs that have negative electricity generations in eGRID (possibly because of their operations in spinning reserve mode) are excluded, since no electricity is supplied by such EGUs to meet the downstream demand. Those CHP facilities that usually have higher efficiencies than EGUs producing electricity alone are also excluded, owing to the lack of consensus on how to allocate emissions between the electricity and heat co-products. Table 1 shows the number and electricity generation share of both CHP and non-CHP facilities by fuel type, in addition to the basic characteristics of EGUs by fuel type.

4 Combined heat and power 
Table 1 The number and electricity generation share of CHP and non-CHP facilities, and basic characteristics of EGUs by fuel type

\begin{tabular}{|c|c|c|c|c|}
\hline & $\begin{array}{c}\text { Number of } \\
\text { facilities }\end{array}$ & $\begin{array}{c}\text { Electricity } \\
\text { generation share } \\
\text { (percentage of total } \\
\text { or subtotal) }\end{array}$ & $\begin{array}{c}\text { Total installed } \\
\text { capacity (MW) }\end{array}$ & $\begin{array}{c}\text { Capacity } \\
\text { factor }\end{array}$ \\
\hline Biomass & 271 & $1.34 \%$ & 43.9 & 0.587 \\
\hline Non-CHP facilities & 88 & $29.15 \%$ & 39.0 & 0.596 \\
\hline CHP facilities & 183 & $70.85 \%$ & 46.2 & 0.584 \\
\hline Coal & 604 & $49.15 \%$ & 629.9 & 0.625 \\
\hline Non-CHP facilities & 427 & $95.42 \%$ & 844.4 & 0.628 \\
\hline CHP facilities & 177 & $4.58 \%$ & 112.4 & 0.569 \\
\hline NG & 1744 & $24.00 \%$ & 253.4 & 0.235 \\
\hline Non-CHP facilities & 1162 & $75.30 \%$ & 323.6 & 0.200 \\
\hline CHP facilities & 582 & $24.70 \%$ & 113.3 & 0.438 \\
\hline Nuclear & 60 & $17.41 \%$ & $1,633.0$ & 0.871 \\
\hline Non-CHP facilities & 60 & $100.00 \%$ & $1,633.0$ & 0.871 \\
\hline Oil & 775 & $1.58 \%$ & 50.7 & 0.199 \\
\hline Non-CHP facilities & 709 & $96.14 \%$ & 53.9 & 0.196 \\
\hline CHP facilities & 66 & $3.86 \%$ & 15.7 & 0.314 \\
\hline Renewable & 1718 & $6.52 \%$ & 67.9 & 0.285 \\
\hline Non-CHP facilities & 1707 & $99.26 \%$ & 68.1 & 0.284 \\
\hline CHP facilities & 11 & $0.74 \%$ & 41.8 & 0.528 \\
\hline Sum & 5172 & $100.00 \%$ & 210.4 & 0.437 \\
\hline
\end{tabular}

Note: The numbers at the bottoms of columns 1 and 2 are sums; the numbers at the bottoms of columns 3 and 4 are the averages of the columns 3 and 4 .

To avoid the biases caused by individual EGUs with unrealistically high or low emission factors, these potential outliers are detected using the modified Z-score, which is defined by Equation (2) (Iglewicz and Hoaglin, 1993):

$$
M_{i}=\frac{0.6745 \times\left(x_{i}-\tilde{x}\right)}{\operatorname{median}\left(\left|x_{i}-\tilde{x}\right|\right)}
$$

where

$M_{i}$ is the modified Z-score;

$x_{i}$ are the GHG and CAP emission factors of an individual $\mathrm{EGU}_{i}$; 
$x$ is the median GHG and CAP emission factor of all EGUs; and

median $\left(\left|x_{i}-\tilde{x}\right|\right)$ is the median absolute deviation.

$x_{i}$ is calculated from Equation (3):

$$
x_{i}=\frac{\text { Emission }_{i}}{N E G_{i}}
$$

where

Emission $_{i}$ is the annual GHG or CAP emission of an individual EGU $\mathrm{E}_{i}$; and

$N E G_{i}$ is the annual net electricity generation of an individual $\mathrm{EGU}_{i}$.

Equation (2) was performed for each specific GHG and CAP emission factor of EGUs using the same fuel subtype and combustion technology. Potential outliers are detected when the modified Z-scores have an absolute value of greater than 3.5. Although the median absolute deviation has been recognized to be a robust measure for outlier detection, there is a possibility that the detected outliers could be due to real fluctuation in the data. Therefore, an additional rejection threshold for outlier detection was set at 1.96 standard deviations $(\sigma)$ of the observations, to allow for real fluctuation in the data. Emission factors with Z-scores larger than 3.5 and exceeding the rejection threshold are removed before Equations (1) and (4-1 or 4-2) are employed to calculate the GHG and CAP emission factors by fuel subtype and combustion technology.

\subsection{CO, VOC, PM AND PM $_{2.5}$ EMISSION FACTORS}

Owing to the lack of direct information on CAP emissions other than $\mathrm{NO}_{\mathrm{x}}$ and $\mathrm{SO}_{\mathrm{x}}$ in eGRID, we utilized the internet version of the Factor Information Retrieval Data System (WebFIRE ${ }^{5}$ ) (EPA, 2011b) and data in the open literature, in conjunction with heat input and NEG data in eGRID, to derive the emission factors of CO, VOC, $\mathrm{PM}_{10}$ and $\mathrm{PM}_{2.5}$.

We employed the fuel-use-related information from eGRID (annual heat input by plant) and the emission factors (expressed in g/unit fuel use) from WebFIRE or the open literature for each specific fuel and combustion technology to calculate CO, VOC, $\mathrm{PM}_{10}$ and $\mathrm{PM}_{2.5}$ emission factors using Equation (4) (Wang, 1999):

5 WebFIRE is a database management system containing EPA's recommended emission factors for criteria and hazardous air pollutants (http://cfpub.epa.gov/webfire). 


$$
\begin{aligned}
E F_{\text {out }, p, f, c t}= & \frac{\sum_{i} \sum_{e c} \frac{H I_{f, c t, i}}{H H V_{f}} \times E F_{i n, f, c t, p} \times\left(1-E R_{p, c c}\right)}{\sum_{i} N E G_{f, c t, i}} \\
E F_{\text {out }, p, f, c t}= & \frac{\sum_{i} \sum_{e c} H I_{f, c t, i} \times E F_{i n, f, c t, p}^{\prime} \times\left(1-E R_{p, e c}\right)}{\sum_{i} N E G_{f, c t, i}}
\end{aligned}
$$

where

$E F_{i n, f, c t, p}$ is the uncontrolled emission factor of CAP $p$ for EGUs burning fuel type $f$ using combustion technology $c t$ in grams per ton of coal or WDS, per 1000 gallons of oil, or per million standard cubic feet of NG;

$E F_{i n, f, c t, p}^{\prime}$ is the uncontrolled emission factor of CAP $p$ for EGUs burning fuel type $f$ using combustion technology $c t$ in $\mathrm{g} / \mathrm{mmBtu}$;

$E R_{p, e c} \quad$ is the emission reduction efficiency of CAP $p$ using control technology ec;

$H_{f, c t, i} \quad$ is the annual heat input (based on the fuel's higher heating value, HHV) to plant $i$ from the burning of fuel type $f$ using combustion technology ct, in mmBtu;

$H H V_{f} \quad$ is the HHV of fuel type $f$, in mmBtu;

$N E G_{f, c t, i} \quad$ is the annual net electricity generation by plant $i$ burning fuel type $f$ using combustion technology $c t$; and

$E F_{\text {out }, p, f, c t} \quad$ is the emission factor of CAP $p$ for EGUs burning fuel type $f$ using combustion technology $c t$, in $\mathrm{g} / \mathrm{kWh}$ of NEG.

For EGUs fired by a specific fuel type, $H I_{f, c t, i}$ and $N E G_{f, c t, i}$ are obtained from eGRID. For BIT-, SUB-, LIG-, NG-, RFO-, DFO-, JF- and WDS-fired EGUs, the $H H V_{f}$ values are obtained from the fuel specifications incorporated in GREET 1_2011. The HHV, rather than the lower heating value (LHV), is adopted because HHV is used for calculating the heat input in eGRID, which is originally obtained from EPA's CAMD (EPA, 2007a) or EIA's Form 923 data (EIA, 2007a) when the former is not available. For other fuel-fired EGUs which account for a small percentage of the total generation, e.g., SC-, WC- and LFG-fired EGUs, the term $\frac{H I_{f, c t, i}}{H H V_{f}}$ in Equation (4-1), representing the quantity of fuel consumption, is obtained from EIA's Form 923 data (EIA, 2007a). 
As mentioned earlier, $E F_{i n, f, c t, p}$ and $E F_{i n, f, c t, p}^{\prime}$ are mainly obtained from WebFIRE. WebFIRE includes information about various industries and their processes, the chemicals emitted, and the associated emission factors. WebFIRE allows easy access to criteria and hazardous air pollutant emission factors obtained from the Compilation of Air Pollutant Emission Factors (AP-42) (EPA, 2011c), the Locating and Estimating documents (EPA, 2010b), and the retired Aerometric Facility Subsystem Emission Factors and Crosswalk/Air Toxics Emission Factors documents.

We used a four-step procedure (described below) to determine the emission factors from WebFIRE for each type of EGU burning a specific type of fuel using a certain combustion technology with a particular control technology. For example, the CAP emission factors of a BIT-fired power plant using a cyclone furnace can be obtained by following these four steps:

Step 1: Identify the combustion technology, e.g., external combustion boilers;

Step 2: Identify the emission source category, i.e., electricity generation sector;

Step 3: Identify the fuel type, e.g., bituminous/subbituminous coal;

Step 4: Identify the combustion technology type and emission control technology, e.g., pulverized coal, cyclone furnace.

Usually, the above four-step procedure narrows down the emission factors to one set of CAPs reflecting the effects of the boiler type, the firing type and the specific emission control measures in operation. It is therefore necessary to identify the combustion technology type and the emission control measures in operation at each EGU covered in eGRID in order to obtain the appropriate emission factor from WebFIRE. Here, the boiler type and firing type of individual EGUs are obtained from EPA's CAMD (2007a). Furthermore, EPA's CAMD unit-level data, including information on emission control equipment at existing EGUs (EPA, 2007a), are used to identify the different emission control measures adopted by each EGU.

$\mathrm{PM}_{10}$ and $\mathrm{PM}_{2.5}$ emission factors are complex functions of boiler bottom and firing configuration, boiler operation, pollution control equipment, and fuel properties. Here, the plant-levelcontrolled PM emission factors are calculated using Equation (5), which accounts for the emission reduction efficiency of the emission control technology and the prime mover-level heat input as obtained from EPA's CAMD. The uncontrolled emission factors and some controlled emission factors are obtained from WebFIRE. The emission reduction efficiencies of control technologies are based on AP-42 and open-literature data, and the fuel quality data are from EIA (2007b).

$$
E F_{P M_{\text {conrolled } f, c, t, i}}=E F_{P M_{\text {uncontrolled }, f, c, i}} \times \sum_{j}\left[\left(1-E R_{j}\right) \times H I(\%)_{j}\right]
$$


where
$E F_{P M_{\text {controlled }, f, c t, i}}$ and $E F_{P M_{\text {uncontrolled }, f, c t, i}}$ are the controlled and uncontrolled PM emission factors, respectively, for plant i burning fuel type $\mathrm{f}$ using combustion technology ct;
$E R_{j}$ is the emission reduction efficiency of control technology j, such as electrostatic precipitator or baghouse; and
$H I(\%)_{j}$
is the heat input share of generators that are employing control technologies j within the same plant.

When multiple emission factors for a particular CAP are available for the same fuel type and combustion technology using the same emission control technology, the technology with a higher quality grade and the post-NSPS (New Source Performance Standards) boilers are adopted. The CO, VOC, $\mathrm{PM}_{10}$ and $\mathrm{PM}_{2.5}$ emission factors chosen from WebFIRE for power plants are given in Tables 2-5 for various fuel types, combustion technologies, boiler bottom and firing types, and emission control technologies. 
TABLE 2 CO emission factors of EGUs by fuel type, combustion technology, boiler bottom and firing type, and emission control technology

\begin{tabular}{|c|c|c|c|c|c|c|}
\hline & Uncontrolled & OFA $^{\mathrm{a}}$ & $\mathrm{LNB}^{\mathrm{b}}$ & FGR $^{\mathrm{c}}$ & $\mathrm{WI}^{\mathrm{d}}$ & $\begin{array}{l}\text { Combustion } \\
\text { optimization }\end{array}$ \\
\hline \multicolumn{7}{|c|}{ Coal (unit: lb/ton) } \\
\hline BIT, BLR ${ }^{\mathrm{e}}, \mathrm{PC}^{\mathrm{f}}$, dry bottom & 0.5 & & 0.5 & & & \\
\hline BIT, BLR, PC, wet bottom & 0.5 & & & & & \\
\hline BIT, BLR, tangential & 0.5 & & 0.5 & & & \\
\hline $\mathrm{BIT}, \mathrm{FBC}^{\mathrm{g}}$ & 18 & & & & & \\
\hline BIT, Stoker & 5 & & & & & \\
\hline BIT, Cyclone & 0.5 & & & & & \\
\hline SUB, BLR, PC, dry bottom & 0.5 & & & & & \\
\hline SUB, BLR, PC, wet bottom & 0.5 & & & & & \\
\hline SUB, BLR, tangential & 0.5 & & & & & \\
\hline SUB, FBC & 18 & & & & & \\
\hline SUB, Stoker & 5 & & & & & \\
\hline SUB, Cyclone & 0.5 & & & & & \\
\hline SUB, Cell & 0.5 & & & & & \\
\hline LIG, BLR, PC, dry bottom & 0.25 & 0.48 & 0.48 & & & \\
\hline LIG, BLR, tangential & 0.6 & 0.1 & & & & \\
\hline LIG, Cyclone & 0.6 & & & & & \\
\hline LIG, FBC & 0.15 & & & & & \\
\hline PetCoke, BLR & 0.6 & & & & & \\
\hline \multicolumn{7}{|c|}{ NG (unit: lb/million scf ${ }^{\mathrm{h}}$ ) } \\
\hline NG, BLR & 84 & & & & & \\
\hline NG, BLR, tangential & 24 & & & 98 & & \\
\hline NG, ICE ${ }^{\mathrm{i}}$ & 399 & & & & & \\
\hline $\mathrm{NG}, \mathrm{CT}^{\mathrm{j}, \mathrm{k}}$ & 0.082 & & & & 0.03 & 0.015 \\
\hline LFG, CT $^{\mathrm{k}}$ & 0.44 & & & & & \\
\hline BFG, BLR & 13.7 & & & & & \\
\hline DG, BLR & 84 & & & & & \\
\hline $\mathrm{DG}, \mathrm{CT}^{\mathrm{k}}$ & 0.017 & & & & & \\
\hline \multicolumn{7}{|c|}{ Oil (unit: lb/1000 gal) } \\
\hline RFO, BLR & 5 & & & & & \\
\hline DFO, BLR & 5 & & & & & \\
\hline DFO, CT & 0.459 & & & & 10.56 & \\
\hline DFO, ICE & 0.95 & & & & & \\
\hline KER, CT ${ }^{\mathrm{k}}$ & 0.0033 & & & & & \\
\hline WO, BLR & 5 & & & & & \\
\hline \multicolumn{7}{|c|}{ Biomass (unit: lb per mmBtu) } \\
\hline Dry WDS, BLR, $\leq 20 \%$ moisture & 0.6 & & & & & \\
\hline Wet WDS, BLR, $\geq 20 \%$ moisture & 0.6 & & & & & \\
\hline BLQ, BLR & 0.0165 & & & & & \\
\hline
\end{tabular}

\footnotetext{
OFA stands for overfire air.

LNB stands for low nitrogen burners.

FGR stands for flue gas recirculation.

WI stands for water injection.

BLR stands for boilers.

PC stands for pulverized coal.

FBC stands for fluidized bed combustion.

scf refers to a cubic foot of volume at $60^{\circ} \mathrm{F}$ and $101.325 \mathrm{kPa}$ of pressure.

ICE stands for internal combustion engines.

CT stands for combustion turbines.

k Unit is $\mathrm{lb} / \mathrm{mmBtu}$.
} 
TABLE 3 VOC emission factors of EGUs by fuel type, combustion technology, boiler bottom and firing type, and emission control technology

\begin{tabular}{|c|c|c|c|}
\hline & Uncontrolled & Wet scrubber & $\mathrm{ESP}^{\mathrm{a}}$ \\
\hline \multicolumn{4}{|c|}{ Coal (unit: lb/ton) } \\
\hline BIT, BLR, PC, dry bottom & 0.06 & & \\
\hline BIT, BLR, PC, wet bottom & 0.04 & & \\
\hline BIT, BLR, tangential & 0.06 & & \\
\hline BIT, FBC & 0.05 & & \\
\hline BIT, Stoker & 0.05 & & \\
\hline BIT, Cyclone & 0.11 & & \\
\hline SUB, BLR, PC, dry bottom & 0.06 & & \\
\hline SUB, BLR, PC, wet bottom & 0.04 & & \\
\hline SUB, BLR, tangential & 0.06 & & \\
\hline SUB, FBC & 0.05 & & \\
\hline SUB, Stoker & 0.05 & & \\
\hline SUB, Cyclone & 0.06 & & \\
\hline SUB, Cell & 0.06 & & \\
\hline LIG, BLR, PC, dry bottom & 0.07 & & \\
\hline LIG, BLR, tangential & 0.07 & & \\
\hline LIG, Cyclone & 0.07 & & \\
\hline LIG, FBC & 0.07 & & \\
\hline PetCoke, BLR & 0.07 & & \\
\hline \multicolumn{4}{|c|}{ NG (unit: lb/million scf) } \\
\hline NG, BLR & 5.5 & & \\
\hline NG, BLR (tangential) & 5.5 & & \\
\hline NG, ICE & 116 & & \\
\hline $\mathrm{NG}, \mathrm{CT}^{\mathrm{b}}$ & 0.0021 & & \\
\hline $\mathrm{LFG}, \mathrm{CT}^{\mathrm{b}}$ & 0.013 & & \\
\hline BFG, BLR & $0.4457^{\mathrm{C}}$ & & \\
\hline DG, BLR & 5.5 & & \\
\hline DG, $\mathrm{CT}^{\mathrm{a}}$ & 0.0058 & & \\
\hline \multicolumn{4}{|c|}{ Oil (unit: lb/1000 gal) } \\
\hline RFO, BLR & 0.76 & & \\
\hline DFO, BLR & 0.2 & & \\
\hline DFO, CT & 0.057 & & \\
\hline DFO, ICE & 0.36 & & \\
\hline JF, CT & 0.0033 & & \\
\hline $\mathrm{KER}, \mathrm{CT}^{\mathrm{b}}$ & 0.004 & & \\
\hline WO, BLR & 1 & & \\
\hline \multicolumn{4}{|c|}{ Biomass (unit: lb/mmBtu) } \\
\hline Dry WDS, BLR, $\leq 20 \%$ moisture & 0.017 & & \\
\hline Wet WDS, BLR, $\geq 20 \%$ moisture & 0.017 & & \\
\hline $\mathrm{BLQ}, \mathrm{BLR}^{\mathrm{c}}$ & 0.4237 & $0.114^{\mathrm{d}}$ & $0.0138^{\mathrm{d}}$ \\
\hline
\end{tabular}


TABLE 4 PM $_{10}$ emission factors of EGUs by fuel type, combustion technology, boiler bottom and firing type, and emission control technology

\begin{tabular}{|c|c|c|c|c|c|}
\hline & Uncontrolled & ESP & Baghouse $^{\mathrm{a}}$ & Multiple cyclones & Scrubber \\
\hline \multicolumn{6}{|c|}{ Coal (unit: lb/ton) } \\
\hline BIT, BLR, PC, dry bottom, w/ FGD & $2.3 * \mathrm{~A}+0.469$ & $0.054 * \mathrm{~A}+0.469$ & $0.02 * \mathrm{~A}+0.469$ & $0.58 * \mathrm{~A}+0.469$ & $0.42 * \mathrm{~A}+0.469$ \\
\hline BIT, BLR, PC, dry bottom, w/o FGD & $\begin{array}{l}2.3 * A+(0.1 * S- \\
0.03) * 23.44\end{array}$ & $\begin{array}{l}0.054 * \mathrm{~A}+(0.1 * \mathrm{~S}- \\
0.03) * 23.44\end{array}$ & $\begin{array}{l}0.02 * \mathrm{~A}+(0.1 * \mathrm{~S}- \\
0.03) * 23.44\end{array}$ & $\begin{array}{l}0.58 * \mathrm{~A}+(0.1 * \mathrm{~S}- \\
0.03) * 23.44\end{array}$ & $\begin{array}{l}0.42 * \mathrm{~A}+(0.1 * \mathrm{~S}- \\
0.03) * 23.44\end{array}$ \\
\hline BIT, BLR, PC, wet bottom, w/ FGD & $2.6 * A+0.469$ & $0.042 * A+0.469$ & & $1.3 * \mathrm{~A}+0.469$ & \\
\hline BIT, BLR, PC, wet bottom, w/o FGD & $\begin{array}{l}2.6 * A+(0.1 * S- \\
0.03) * 23.44\end{array}$ & $\begin{array}{l}0.042 * \mathrm{~A}+(0.1 * \mathrm{~S}- \\
0.03) * 23.44\end{array}$ & & $\begin{array}{l}1.3 * \mathrm{~A}+(0.1 * \mathrm{~S}- \\
0.03) * 23.44\end{array}$ & \\
\hline BIT, BLR, tangential, w /FGD & $2.3 * \mathrm{~A}+0.469$ & $0.054 * \mathrm{~A}+0.469$ & $0.02 * \mathrm{~A}+0.469$ & $0.58 * \mathrm{~A}+0.469$ & $0.42 * \mathrm{~A}+0.469$ \\
\hline BIT, BLR, tangential, w/o FGD & $\begin{array}{l}2.3 * \mathrm{~A}+(0.1 * \mathrm{~S}- \\
0.03) * 23.44 \\
\end{array}$ & $\begin{array}{l}0.054 * \mathrm{~A}+(0.1 * \mathrm{~S}- \\
0.03) * 23.44\end{array}$ & $\begin{array}{l}0.02 * \mathrm{~A}+(0.1 * \mathrm{~S}- \\
0.03) * 23.44\end{array}$ & $\begin{array}{l}0.58 * A+(0.1 * S- \\
0.03) * 23.44\end{array}$ & $\begin{array}{l}0.42 * \mathrm{~A}+(0.1 * \mathrm{~S}- \\
0.03) * 23.44\end{array}$ \\
\hline BIT, FBC & 12.9 & & & & \\
\hline BIT, Stoker & 14.2 & 1.48 & 1.11 & 10.9 & \\
\hline BIT, Cyclone & $\begin{array}{l}0.26 * \mathrm{~A}+(0.1 * \mathrm{~S}- \\
0.03) * 23.44\end{array}$ & $\begin{array}{l}0.011 * \mathrm{~A}+(0.1 * \mathrm{~S}- \\
0.03) * 23.44\end{array}$ & & $\begin{array}{l}0.112 * \mathrm{~A}+(0.1 * \mathrm{~S}- \\
0.03) * 23.44\end{array}$ & \\
\hline SUB, BLR, PC, dry bottom, w/ FGD & $2.3 * \mathrm{~A}+0.4$ & $(\mathbf{0 . 0 1}) * 2.3 * \mathrm{~A}+0.4$ & $(\mathbf{0 . 0 0 1}) * 2.3 * \mathrm{~A}+0.4$ & $(\mathbf{0 . 0 7 5}) * 2.3 * \mathrm{~A}+0.4$ & $(\mathbf{0 . 0 3}) * 2.3 * \mathrm{~A}+0.4$ \\
\hline SUB, BLR, PC, dry bottom, w/o FGD & $\begin{array}{l}2.3 * A+(0.1 * S- \\
0.03) * 20\end{array}$ & $\begin{array}{l}(\mathbf{0 . 0 1}) * 2.3 * A+(0 . \\
1 * S-0.03) * 20\end{array}$ & $\begin{array}{l}(\mathbf{0 . 0 0 1}) * 2.3 * \mathrm{~A}+(0.1 \\
* \mathrm{~S}-0.03) * 20\end{array}$ & $\begin{array}{l}(\mathbf{0 . 0 7 5}) * 2.3 * \mathrm{~A}+(0.1 \\
* \mathrm{~S}-0.03) * 20\end{array}$ & $\begin{array}{l}(\mathbf{0 . 0 3}) * 2.3 * \mathrm{~A}+(0.1 * \mathrm{~S} \\
-0.03) * 20\end{array}$ \\
\hline SUB, BLR, PC, wet bottom & $\begin{array}{l}2.6 * A+(0.1 * S- \\
0.03) * 20\end{array}$ & & & & \\
\hline SUB, BLR, tangential & $\begin{array}{l}2.3 * \mathrm{~A}+(0.1 * \mathrm{~S}- \\
0.03) * 20\end{array}$ & & & & \\
\hline SUB, FBC & 16.6 & & & & \\
\hline SUB, Stoker & 14 & & & & \\
\hline SUB, Cyclone & $\begin{array}{l}0.26 * \mathrm{~A}+(0.1 * \mathrm{~S}- \\
0.03) * 20\end{array}$ & & & & \\
\hline SUB, Cell & $\begin{array}{l}2.3 * \mathrm{~A}+(0.1 * \mathrm{~S}- \\
0.03) * 20 \\
\end{array}$ & & & & \\
\hline LIG, BLR, PC, dry bottom, w/ FGD & $0.79 * 2.3 * \mathrm{~A}+0.29$ & & $0.00018 * \mathrm{~A}+0.29$ & $0.79 * 0.88 * \mathrm{~A}+0.29$ & $0.000945 * A+0.29$ \\
\hline LIG, BLR, PC, dry bottom, w/o FGD & $\begin{array}{l}0.79 * 2.3 * \mathrm{~A}+(0.1 * \mathrm{~S}- \\
0.03) * 14.5\end{array}$ & & $\begin{array}{l}0.00018 * A+(0.1 * S- \\
0.03) * 14.5\end{array}$ & $\begin{array}{l}0.79 * 0.88 * A+(0.1 * \\
\mathrm{S}-0.03) * 14.5\end{array}$ & $\begin{array}{l}0.000945 * A+(0.1 * S- \\
0.03) * 14.5\end{array}$ \\
\hline LIG, BLR, tangential, w/ FGD & $2.3 * \mathrm{~A}+0.29$ & & $0.00018 * \mathrm{~A}+0.29$ & $0.88 * \mathrm{~A}+0.29$ & $0.000945 * \mathrm{~A}+0.29$ \\
\hline LIG, BLR, tangential, w/o FGD & $\begin{array}{l}2.3 * A+(0.1 * S- \\
0.03) * 14.5\end{array}$ & & $\begin{array}{l}0.00018 * A+(0.1 * S- \\
0.03) * 14.5\end{array}$ & $\begin{array}{l}0.88 * A+(0.1 * S- \\
0.03) * 14.5\end{array}$ & $\begin{array}{l}0.000945 * A+(0.1 * S- \\
0.03) * 14.5\end{array}$ \\
\hline
\end{tabular}


TABLE 4 (Cont.)

\begin{tabular}{|c|c|c|c|c|c|}
\hline & Uncontrolled & ESP & Baghouse $^{\mathrm{a}}$ & Multiple cyclones & Scrubber \\
\hline \multicolumn{6}{|c|}{ Coal (unit: lb/ton) } \\
\hline LIG, Cyclone & $\begin{array}{l}0.871 * \mathrm{~A}+(0.1 * \mathrm{~S}- \\
0.03) * 14.5\end{array}$ & & & & \\
\hline LIG, FBC & $100^{b * 0.07 * A+0.32}$ & $0.07 * \mathrm{~A}+0.32$ & $0.07 * \mathrm{~A}+0.32$ & & $30^{\mathrm{c} *} 0.07 * \mathrm{~A}+0.32$ \\
\hline PetCoke, BLR & $7.9 * \mathrm{~A}$ & & & & \\
\hline \multicolumn{6}{|c|}{ NG (unit: lb/million scf) } \\
\hline NG, BLR & 7.6 & $0.076^{\mathrm{d}}$ & & $0.57^{\mathrm{d}}$ & $0.19^{\mathrm{d}}$ \\
\hline NG, BLR, tangential & 7.6 & & & & \\
\hline NG, ICE & 49.3 & & & & \\
\hline $\mathrm{NG}, \mathrm{CT}^{\mathrm{e}}$ & 0.0066 & & & & \\
\hline $\mathrm{LFG}, \mathrm{CT}^{\mathrm{e}}$ & 0.02484 & & & & \\
\hline BFG, BLR & 8.6 & & & & \\
\hline DG, BLR & 7.6 & & & & \\
\hline $\mathrm{DG}, \mathrm{CT}^{\mathrm{e}}$ & 0.01477 & & & & \\
\hline \multicolumn{6}{|c|}{ Oil (unit: lb/1000 gal) } \\
\hline RFO, BLR & $\begin{array}{l}5.9 *(1.12 * \mathrm{~S}+0.37)+1 \\
.5\end{array}$ & $\begin{array}{l}0.042 *(1.12 * S+ \\
0.37)+1.5\end{array}$ & & & $\begin{array}{l}0.5 *(1.12 * \mathrm{~S}+0.37) \\
+1.5\end{array}$ \\
\hline DFO, BLR & 2.3 & & & & \\
\hline DFO, CT & 8.54 & & & & 1.57 \\
\hline DFO, ICE & 0.31 & & & & \\
\hline JF, CT & $0.0615^{\mathrm{f}}$ & & & & 0.0113 \\
\hline KER, CT & $8.54^{\mathrm{g}}$ & & & & $0.012^{\mathrm{e}}$ \\
\hline WO, BLR & $51 * A$ & & & & \\
\hline \multicolumn{6}{|c|}{ Biomass (unit: lb/mmBtu) } \\
\hline Dry WDS, BLR, $\leq 20 \%$ moisture & 0.377 & 0.057 & & 0.287 & \\
\hline Wet WDS, BLR, $\geq 20 \%$ moisture & 0.327 & & 0.091 & 0.217 & \\
\hline BLQ, BLR & $9.322^{h, i}$ & & & & $0.184^{\mathrm{h}}$ \\
\hline
\end{tabular}

Notes: $\quad$ A is the as-fired coal ash weight percentage (\%).

$\mathrm{S}$ is the as-fired coal sulfur weight percentage (\%).

The numbers in bold in parentheses reflect the emission reduction efficiency of the corresponding emission control device in operation, obtained from AP-42 on an average basis. 


\section{TABLE 4 (Cont.)}

PM removal efficiency for baghouse technology is assumed the same as that of ESP.

FPM removal efficiency of 99\% for ESP is adopted, and the uncontrolled PM emission factors are scaled on the basis of the ESP-equipped ones (EPA, 1995b).

c FPM removal efficiencies of 70\% and 99\% for wet scrubber and ESP, respectively, are adopted, and the scrubber-equipped PM emission factors are scaled on the basis of the ESP-equipped ones (EPA, 1995b)

d From AP-42, Chapter 1.1 (EPA, 1995a).

e Unit is $\mathrm{lb} / \mathrm{mmBtu}$.

The uncontrolled $\mathrm{PM}_{10}$ emission factor is calculated assuming that the emission reduction efficiency of steam or water injection treatment for PM 10 emissions from $\mathrm{JF}_{-}$ fired turbines is equivalent to that for PM emissions from DFO-fired turbines.

The uncontrolled $\mathrm{PM}_{10}$ emission factor for DFO is used.

unit is lb/ton.

From Pechan (2003) 
TABLE $5 \quad \mathbf{P M}_{2.5}$ emission factors of EGUs by fuel type, combustion technology, boiler bottom and firing type, and emission control technology

\begin{tabular}{|c|c|c|c|c|c|}
\hline & Uncontrolled & ESP & Baghouse & Multiple cyclones & Scrubber \\
\hline \multicolumn{6}{|c|}{ Coal (unit: lb/ton) } \\
\hline BIT, BLR, PC, dry bottom, w/ FGD & $0.6 * \mathrm{~A}+0.469$ & $0.024 * \mathrm{~A}+0.469$ & $0.01 * \mathrm{~A}+0.469$ & $0.06 * \mathrm{~A}+0.469$ & $0.3 * \mathrm{~A}+0.469$ \\
\hline $\begin{array}{l}\text { BIT, BLR, PC, dry bottom, w/o } \\
\text { FGD }\end{array}$ & $\begin{array}{l}0.6 * \mathrm{~A}+(0.1 * \mathrm{~S}- \\
0.03) * 23.44\end{array}$ & $\begin{array}{l}0.024 * \mathrm{~A}+(0.1 * \mathrm{~S}- \\
0.03) * 23.44\end{array}$ & $\begin{array}{l}0.01 * \mathrm{~A}+(0.1 * \mathrm{~S}- \\
0.03) * 23.44\end{array}$ & $\begin{array}{l}0.06 * \mathrm{~A}+(0.1 * \mathrm{~S}- \\
0.03) * 23.44\end{array}$ & $\begin{array}{l}0.3 * \mathrm{~A}+(0.1 * \mathrm{~S}- \\
0.03) * 23.44\end{array}$ \\
\hline $\begin{array}{l}\text { BIT, BLR, PC, wet bottom, w/ } \\
\text { FGD }\end{array}$ & $1.48 * \mathrm{~A}+0.469$ & $0.022 * \mathrm{~A}+0.469$ & & $0.86 * A+0.469$ & \\
\hline $\begin{array}{l}\text { BIT, BLR, PC, wet bottom, w/o } \\
\text { FGD }\end{array}$ & $\begin{array}{l}1.48 * \mathrm{~A}+(0.1 * \mathrm{~S}- \\
0.03) * 23.44\end{array}$ & $\begin{array}{l}0.022 * \mathrm{~A}+(0.1 * \mathrm{~S}- \\
0.03) * 23.44\end{array}$ & & $\begin{array}{l}0.86 * \mathrm{~A}+(0.1 * \mathrm{~S}- \\
0.03) * 23.44\end{array}$ & \\
\hline BIT, BLR, tangential, w/ FGD & $0.6 * \mathrm{~A}+0.469$ & $0.024 * \mathrm{~A}+0.469$ & $0.01 * \mathrm{~A}+0.469$ & $0.06 * A+0.469$ & $0.3 * \mathrm{~A}+0.469$ \\
\hline BIT, BLR, tangential, w/o FGD & $\begin{array}{l}0.6 * \mathrm{~A}+(0.1 * \mathrm{~S}- \\
0.03) * 23.44\end{array}$ & $\begin{array}{l}0.024 * \mathrm{~A}+(0.1 * \mathrm{~S}- \\
0.03) * 23.44\end{array}$ & $\begin{array}{l}0.01 * \mathrm{~A}+(0.1 * \mathrm{~S}- \\
0.03) * 23.44\end{array}$ & $\begin{array}{l}0.06 * \mathrm{~A}+(0.1 * \mathrm{~S}- \\
0.03) * 23.44\end{array}$ & $\begin{array}{l}0.3 * \mathrm{~A}+(0.1 * \mathrm{~S}- \\
0.03) * 23.44\end{array}$ \\
\hline BIT, FBC & 1.88 & & & & \\
\hline BIT, Stoker & 5.64 & 0.44 & 0.072 & 3.34 & \\
\hline BIT, Cyclone & $\begin{array}{l}0.11 * \mathrm{~A}+(0.1 * \mathrm{~S}- \\
0.03) * 23.44\end{array}$ & $\begin{array}{l}0.0006 * \mathrm{~A}+(0.1 * \mathrm{~S}- \\
0.03) * 23.44\end{array}$ & & $\begin{array}{l}0.11 * \mathrm{~A}+(0.1 * \mathrm{~S}- \\
0.03) * 23.44\end{array}$ & \\
\hline $\begin{array}{l}\text { SUB, BLR, PC, dry bottom, w/ } \\
\text { FGD }\end{array}$ & $0.6 * \mathrm{~A}+0.4$ & $(\mathbf{0 . 0 1}) * 0.6 * \mathrm{~A}+0.4$ & $(\mathbf{0 . 0 0 1}) * 0.6 * \mathrm{~A}+0.4$ & $(\mathbf{0 . 0 7 5}) * 0.6 * \mathrm{~A}+0.4$ & $(\mathbf{0 . 0 3}) * 0.6 * \mathrm{~A}+0.4$ \\
\hline $\begin{array}{l}\text { SUB, BLR, PC, dry bottom, w/o } \\
\text { FGD }\end{array}$ & $\begin{array}{l}0.6 * \mathrm{~A}+(0.1 * \mathrm{~S}- \\
0.03) * 20\end{array}$ & $\begin{array}{l}(\mathbf{0 . 0 1}) * 0.6 * \mathrm{~A}+(0.1 * \mathrm{~S}- \\
0.03) * 20\end{array}$ & $\begin{array}{l}(\mathbf{0 . 0 0 1}) * 0.6 * \mathrm{~A}+(0.1 * \mathrm{~S} \\
-0.03) * 20\end{array}$ & $\begin{array}{l}(\mathbf{0 . 0 7 5}) * 0.6 * \mathrm{~A}+(0.1 \\
* \mathrm{~S}-0.03) * 20\end{array}$ & $\begin{array}{l}(\mathbf{0 . 0 3}) * 0.6 * \mathrm{~A}+(0.1 * \\
\mathrm{S}-0.03) * 20\end{array}$ \\
\hline SUB, BLR, PC, wet bottom & $\begin{array}{l}1.48 * \mathrm{~A}+(0.1 * \mathrm{~S}- \\
0.03) * 20\end{array}$ & & & & \\
\hline SUB, BLR, tangential & $\begin{array}{l}0.6 * \mathrm{~A}+(0.1 * \mathrm{~S}- \\
0.03) * 20\end{array}$ & & & & \\
\hline SUB, FBC & 1.88 & & & & \\
\hline SUB, Stoker & 5.4 & & & & \\
\hline SUB, Cyclone furnace & $\begin{array}{l}0.11 * \mathrm{~A}+(0.1 * \mathrm{~S}- \\
0.03) * 20\end{array}$ & & & & \\
\hline SUB, Cell & $\begin{array}{l}0.6 * A+(0.1 * S- \\
0.03) * 20\end{array}$ & & & & \\
\hline $\begin{array}{l}\text { LIG, BLR, PC, dry bottom, w/ } \\
\text { FGD }\end{array}$ & $0.79 * 0.66 * \mathrm{~A}+0.29$ & & $0.00008 * \mathrm{~A}+0.29$ & $0.79 * 0.36 * \mathrm{~A}+0.29$ & $0.0005 * \mathrm{~A}+0.29$ \\
\hline $\begin{array}{l}\text { LIG, BLR, PC, dry bottom, w/o } \\
\text { FGD }\end{array}$ & $\begin{array}{l}0.79 * 0.66 * \mathrm{~A}+(0.1 * \\
\mathrm{S}-0.03) * 14.5\end{array}$ & & $\begin{array}{l}0.00008 * \mathrm{~A}+(0.1 * \mathrm{~S}- \\
0.03) * 14.5\end{array}$ & $\begin{array}{l}0.79 * 0.36 * \mathrm{~A}+(0.1 * \\
\mathrm{S}-0.03) * 14.5\end{array}$ & $\begin{array}{l}0.0005 * \mathrm{~A}+(0.1 * \mathrm{~S}- \\
0.03) * 14.5\end{array}$ \\
\hline
\end{tabular}


TABLE 5 (Cont.)

\begin{tabular}{|c|c|c|c|c|c|}
\hline & Uncontrolled & ESP & Baghouse & Multiple cyclones & Scrubber \\
\hline \multicolumn{6}{|c|}{ Coal (unit: lb/ton) } \\
\hline LIG, BLR, tangential, w/ FGD & $0.66 * \mathrm{~A}+0.29$ & & $0.00008 * \mathrm{~A}+0.29$ & $0.36 * \mathrm{~A}+0.29$ & $0.0005 * \mathrm{~A}+0.29$ \\
\hline LIG, BLR, tangential, w/o FGD & $\begin{array}{l}0.66 * A+(0.1 * S- \\
0.03) * 14.5\end{array}$ & & $\begin{array}{l}0.00008 * \mathrm{~A}+(0.1 * \mathrm{~S}- \\
0.03) * 14.5\end{array}$ & $\begin{array}{l}0.36 * A+(0.1 * S- \\
0.03) * 14.5\end{array}$ & $\begin{array}{l}0.0005 * \mathrm{~A}+(0.1 * \mathrm{~S}- \\
0.03) * 14.5\end{array}$ \\
\hline LIG, Cyclone & $\begin{array}{l}0.369 * \mathrm{~A}+(0.1 * \mathrm{~S}- \\
0.03) * 14.5\end{array}$ & & & & \\
\hline LIG, FBC & $\begin{array}{l}0.27^{\mathrm{a}} *\left(100^{\mathrm{b}} *\right. \\
\left.0.07^{*} \mathrm{~A}+0.32\right)\end{array}$ & $0.27^{\mathrm{a} *}(0.07 * \mathrm{~A}+0.32)$ & $0.27^{\mathrm{a} *}(0.07 * \mathrm{~A}+0.32)$ & & $\begin{array}{l}0.27^{\mathrm{a}} *\left(30^{\mathrm{C}} * 0.07 * \mathrm{~A}\right. \\
+0.32)\end{array}$ \\
\hline PetCoke, BLR & $4.5 * \mathrm{~A}$ & & & & \\
\hline \multicolumn{6}{|c|}{ NG (unit: lb/million scf) } \\
\hline NG, BLR & 7.6 & $0.19^{\mathrm{d}}$ & & $0.57^{\mathrm{d}}$ & $0.076^{\mathrm{d}}$ \\
\hline NG, BLR, tangential & 7.6 & & & & \\
\hline NG, ICE & 49.3 & & & & \\
\hline $\mathrm{NG}, \mathrm{CT}^{\mathrm{e}}$ & 0.0066 & & & & \\
\hline LFG, CT & $0.02484^{\mathrm{e}}$ & & & & \\
\hline BFG, BLR & 8.6 & & & & \\
\hline DG, BLR & 7.6 & & & & \\
\hline $\mathrm{DG}, \mathrm{CT}^{\mathrm{e}}$ & 0.01477 & & & & \\
\hline \multicolumn{6}{|c|}{ Oil (unit: lb/1000 gal) } \\
\hline RFO, BLR & $\begin{array}{l}4.3 *(1.12 * S+0.37)+ \\
1.5\end{array}$ & $\begin{array}{l}0.028 *(1.12 * S+0.37)+ \\
1.5\end{array}$ & & & $\begin{array}{l}0.48 *(1.12 * S+0.37) \\
+1.5\end{array}$ \\
\hline DFO, BLR & 1.55 & & & & \\
\hline DFO, CT & $2.05^{\mathrm{f}}$ & & & & 1.54 \\
\hline DFO, ICE & 0.31 & & & & \\
\hline JF, CT & $0.0148^{\mathrm{g}}$ & & & & 0.0111 \\
\hline KER, CT & $2.05^{\mathrm{h}}$ & & & & $0.01107^{\mathrm{e}}$ \\
\hline WO, BLR & $28.8 * \mathrm{~A}$ & & & & \\
\hline \multicolumn{6}{|c|}{ Biomass (unit: lb/mmBtu) } \\
\hline Dry WDS, BLR, $\leq 20 \%$ moisture & 0.267 & 0.052 & & 0.137 & \\
\hline Wet WDS, BLR, $\geq 20 \%$ moisture & 0.307 & & 0.082 & 0.177 & \\
\hline $\mathrm{BLQ} \mathrm{BLR}^{\mathrm{i}, \mathrm{j}}$ & 2.3305 & & & & $0.184^{\mathrm{i}}$ \\
\hline
\end{tabular}

Notes: $\quad A$ is the as-fired coal ash weight percentage (\%).

$\mathrm{S}$ is the as-fired coal sulfur weight percentage (\%).

The numbers in bold in parentheses reflect the emission reduction efficiency of the corresponding emission control device in operation, obtained from AP-42 on an average basis. 


\section{TABLE 5 (Cont.)}

a A PM cumulative $\mathrm{PM}_{25}$ mass percentage out of $\mathrm{PM}_{10}$ for pulverized lignite (0.27) is adopted (EPA, 1995b).

FPM removal efficiency of $99 \%$ for ESP is adopted, and the uncontrolled PM emission factors are scaled on the basis of the ESP-equipped ones (EPA, 1995b).

FPM removal efficiencies of $70 \%$ and $99 \%$ for wet scrubber and ESP, respectively, are adopted, and the scrubber-equipped PM emission factors are scaled on the basis of the ESP-equipped ones (EPA, 1995b).

d From AP-42, Chapter 1 (EPA, 1995a).

e Unit is lb/mmBtu;

The $\mathrm{PM}_{2.5}$ emission factor is calculated on the basis of the size-specific mass percentage of $\mathrm{PM}_{2.5}$ and $\mathrm{PM}_{10}$ for uncontrolled industrial boilers.

$\mathrm{g}$ The uncontrolled $\mathrm{PM}_{2.5}$ emission factor is calculated assuming that the emission reduction efficiency of steam or water injection treatment for PM emissions from JF-fired turbines is equivalent to that for $\mathrm{PM}_{2.5}$ emissions from DFO-fired turbines.

h The uncontrolled $\mathrm{PM}_{2.5}$ emission factor for DFO is used.

i Unit is $\mathrm{lb} /$ ton.

j From Pechan (2003) 
Special attention was given to the estimation of primary (total) $\mathrm{PM}_{10}$ and $\mathrm{PM}_{2.5}$ emission factors. Particulate matter consists of filterable particulate matter (FPM) that is trapped by the glass fiber filter plus condensable particulate matter (CPM) that is emitted in the vapor state but later condenses to form homogeneous and/or heterogeneous aerosol particles (EPA, 1995a). The CPM emission factors of coal- and oil-fired EGUs are dependent on the sulfur content of coal and oil and on whether a flue gas desulfurization (FGD) control is in place or not. Thus, the primary $\mathrm{PM}_{10}$ and $\mathrm{PM}_{2.5}$ emission factors of FPM and FGD-dependent CPM for coal-fired EGUs are estimated by separate terms in Tables 4 and 5, with the first and the second terms representing FPM and CPM emission factors, respectively.

Tables 4 and 5 show that the FPM and CPM portions of the $\mathrm{PM}_{10}$ and $\mathrm{PM}_{2.5}$ emission factors for BIT-, SUB-, LIG- and RFO-fired EGUs are determined by the ash content (A) and the sulfur content (S), respectively. A default condensable $\mathrm{PM}_{10}$ and $\mathrm{PM}_{2.5}$ emission factor of 0.01 $\mathrm{lb} / \mathrm{mmBtu}$ rather than the emission equation $(0.1 * \mathrm{~S}-0.03)$ is used when the sulfur content of coal is $0.4 \%$ or less (EPA, 1995a). Since the FGD control determines the condensable PM emission factors, these factors are calculated by applying the FGD deployment rate weighted by the generator-level heat input for each plant, as shown in Equation (6).

$$
C P M_{f, i, j}=F G D_{-} \text {rate }_{i} \times C P M_{f, F G D_{-} w /, j}+\left(1-F G D_{-} \text {rate }_{i}\right) \times C P M_{f, F G D_{-} w / o, j}
$$

where

$$
\begin{array}{ll}
C P M_{f, i, j} & \text { is the CPM emission factor of plant } i \text { burning fuel type } f \text { with emission } \\
& \text { control technology } j ; \\
F G D_{-} \text {rate }_{i} & \text { is the heat-input-weighted FGD deployment rate of plant } i ; \\
C P M_{f, F G D_{-} w /, j} & \begin{array}{l}
\text { is the CPM emission factor for fuel type } f \text { with emission control } \\
\text { technology } j \text { with FGD control; and }
\end{array} \\
C P M_{f, F G D_{-} w / o, j} & \begin{array}{l}
\text { is the CPM emission factor for fuel type } f \text { with emission control } \\
\text { technology } j \text { without FGD control. }
\end{array}
\end{array}
$$

The FGD_rate ${ }_{i}$ is calculated on the basis of the deployment of $\mathrm{SO}_{\mathrm{x}}$ emission control devices as obtained from EPA's CAMD (EPA, 2007a). From CAMD, the FGD deployment rate by U.S. EGUs is $33.2 \%$ (nameplate capacity basis), which agrees well with the $33 \%$ deployment rate reported by EPA (EPA, 2009a).

$C P M_{f, F G D_{-} w /, j}$ and $C P M_{f, F G D_{-} w / o, j}$ are derived from WebFIRE and AP-42, as shown in Tables 4 and 5. It is clear that $C P M_{f, F G D_{-} w / o, j}$ for coal-fired EGUs are dependent on the fuel sulfur contents. A high-sulfur coal would result in significantly higher CPM than FPM, and eventually a high total primary PM emission factor. With reported measurements of both FPM and CPM emission factors for coal-fired EGUs (Corio and Sherwell, 2000; Farber et al., 2004), EPA 
developed refined FPM/CPM ratios, which split the primary $\mathrm{PM}_{10}$ and $\mathrm{PM}_{2.5}$ emission factors by 40/60 and 20/80 for the FPM and CPM, respectively. These split ratios were used for the development of refined PM emission estimates in the National Emission Inventory (Pechan, 2005). In the present report, the WebFIRE- and AP-42-based $\mathrm{PM}_{10}$ and $\mathrm{PM}_{2.5}$ emission factors for coal-fired EGUs are first calculated, and then checked against the FPM/CPM split using Equations $7 \mathrm{a}$ and $7 \mathrm{~b}$ for $\mathrm{PM}_{10}$ and $\mathrm{PM}_{2.5}$ emission factors, respectively:

$$
\begin{gathered}
P M_{10, \text { adjusted }}=F P M_{10}+\min \left(C P M_{10}, 1.5 \times F P M_{10}\right) \\
P M_{2.5, \text { adjusted }}=F P M_{2.5}+\min \left(C P M_{2.5}, 4.0 \times F P M_{2.5}\right)
\end{gathered}
$$

where

$$
\begin{array}{ll}
P M_{10, \text { adjusted and }} P M_{2.5, \text { adjusted }} & \text { are adjusted } \mathrm{PM}_{10} \text { and } \mathrm{PM}_{2.5} \text { emission factors, respectively; } \\
F P M_{10} \text { and } F P M_{2.5} & \text { are the WebFIRE and AP-42-based filterable } \mathrm{PM}_{10} \text { and } \mathrm{PM}_{2.5} \\
& \text { emission factors, respectively; and } \\
& \text { are the WebFIRE and AP-42-based condensable } \mathrm{PM}_{10} \text { and } \\
& \mathrm{PM}_{2.5} \text { emission factors, respectively. }
\end{array}
$$

For RFO-fired boilers, removal efficiencies of $77.96 \%$ and $92.93 \%$ for $\mathrm{PM}_{10}$ and $\mathrm{PM}_{2.5}$, respectively, are assigned to the multiple-cyclone-controlled boilers according to AP-42 (EPA, 1995c).

To evaluate whether the reported data for woody biomass-fired boilers are dry-basis or wet-basis, the heating value of the woody biomass as obtained from the EIA's monthly fuel consumption and heat content data at the plant level (EIA, 2007a) is used. We made the assumption that woody biomass with HHV greater than $15 \mathrm{mmBtu} /$ ton is considered dry and otherwise it is considered wet. This assumption is based on the heating value, which ranges from $9 \mathrm{mmBtu} / \mathrm{ton}$ for wet-basis to $16 \mathrm{mmBtu} /$ ton for dry-basis woody biomass (EPA, 1995d).

For the coal-fired integrated gasification combined cycle (IGCC) technology, there is only one EGU (ORIS code 7242) reported in eGRID that employs bituminous coal-fired IGCC components. However, the IGCC component of that plant has a very low generator capacity factor (0.0055 and 0.1109 for the steam turbine and the combustion turbine part, respectively), with a very low combined efficiency of $5 \%$, which does not represent the performance of this type of advanced combustion technology, expected to be in the range of 41.2\%-44.5\% (NETL, 2010). As a result, we have not calculated the GHG and CAP emission factors of coal-fired IGCC plants based on eGRID. Nevertheless, we estimated the CAP emission factor on the basis of the modeled performances of three hypothetical IGCC power plant configurations, assuming that they use technologies available today (NETL, 2010), and the CAP emission factors for BIT, SUB and LIG using equipment and processes available for deployment in the 2010 time period (EPA, 2006). 
For natural gas combined cycle (NGCC) plants, 0.000242 and $0.0004973 \mathrm{lb} / \mathrm{mmBtu}$ are adopted as the emission factors of PM and VOC, respectively, on the basis of the in-stack flue gas measurement of one NGCC plant (England et al., 2004). A CO emission factor of 0.02669 $\mathrm{g} / \mathrm{kWh}$, which was modeled on an energy balance and mass balance basis from an NGCC plant with an LHV-based efficiency of 54.1\% (Spath and Mann, 2000), is used in this work for estimation of the CO emission factors for individual NGCC plants, using Equation (8). As for other types of power plants, the $\mathrm{NO}_{\mathrm{x}}$ and $\mathrm{SO}_{\mathrm{x}}$ emission data from eGRID are used to calculate their emission factors for NGCC plants.

$$
E F_{c o, i}=E F_{c o, N R E L} \times \frac{\eta_{N E R L}}{\eta_{i}}
$$

where

$E F_{c o, i}$ and $E F_{C o, N R E L}$ are the CO emission factors in $\mathrm{g} / \mathrm{kWh}$ for NGCC plant $i$ and for the NREL NGCC plant, respectively; and

$\eta_{i}$ and are the LHV-based efficiencies for NGCC plant $i$ and for the NREL NGCC plant, respectively.

The CAP emissions are approximated for SC-, WC-, TDF-, AB-, MSB-, OBS-, OBL-, WDL-, OG-, OTH- and purchased steam (PUR)-fired EGUs, whose net electricity generation accounts for a small fraction of the total and for which no data are available for the estimation of their CAP emissions. The emission factors of BIT-fired EGUs are applied to SC-fired EGUs after accounting for the difference in fuel properties, e.g., decreased ash and sulfur contents, and increased heating value. For WC-fired EGUs, with a much higher ash content, the CAP emissions are calculated using the emission factors of LIG-fired EGUs and adjusted by the ash and sulfur contents of WC. The BIT-fired emission factors are used to approximate the CAP emissions for TDF-fired EGUs. Emission factors of NG-fired EGUs are used to estimate the CAP emissions of OG-, OTH- and PUR-fired EGUs. The dry-basis WDS emission factors are used to estimate the CAP emissions of AB-, MSB- and OBS-fired EGUs, while the wet-basis WDS emission factors are used to estimate the CAP emissions of OBL- and WDL-fired EGUs.

For PC-, BLQ-, BFG-, DG-, KER- and WO-fired EGUs, the CAP emissions are calculated from the CAP emission factors compiled in Tables 2-5, based on WebFIRE.

In Tables 2-5, only uncontrolled or LNB emission factors for CO and VOC are available for most EGUs. Also, we noticed that some EGUs, like the BIT-fired EGUs that utilize FBC or stokers, have only uncontrolled $\mathrm{PM}_{10}$ and $\mathrm{PM}_{2.5}$ emission factors, since no particular control technologies are deployed there. 


\subsection{SULFUR CONTENTS AND ASH CONTENTS OF VARIOUS FUELS BY STATE}

As mentioned earlier, the ash content and sulfur content of the fuels are needed to calculate the $\mathrm{PM}_{10}$ and $\mathrm{PM}_{2.5}$ emission factors for various combustion technologies. On the basis of $2007 \mathrm{EIA}$ FERC-423 data (EIA, 2007b), the sulfur contents and ash contents of BIT, SUB, LIG, NG, RFO, DFO, JF, KER, PC, SC, WC and WO by state are calculated on the basis of the weighted average fuel consumption of each fuel. For those states where no relevant data are available, the weighted averages of all other states are used. Tables 6 and 7 summarize the sulfur contents and ash contents, respectively, of BIT-, SUB-, LIG-, SC-, WC-, PC-, NG-, RFO-, DFO- and JF-fired EGUs by state on an as-received basis in year 2007.

\section{TABLE 6 Sulfur contents (weight \%) of various fuels on an as-received basis in each state in year 2007}

\begin{tabular}{|c|c|c|c|c|c|c|c|c|c|c|}
\hline & BIT & SUB & LIG & SC & WC & PC & NG & RFO & DFO & JF \\
\hline$\overline{\mathrm{AL}}$ & 1.26090 & 0.31310 & 0.90642 & 1.34802 & 1.72178 & 4.51377 & 0.00000 & 0.89493 & 0.26332 & 0.01394 \\
\hline AK & 1.53553 & 0.35683 & 0.90642 & 1.61427 & 1.72178 & 4.51377 & 0.00000 & 0.89493 & 0.14995 & 0.01394 \\
\hline $\mathrm{AZ}$ & 0.55001 & 0.58052 & 0.90642 & 1.61427 & 1.72178 & 4.51377 & 0.00000 & 0.89493 & 0.35438 & 0.01394 \\
\hline AR & 1.53553 & 0.25751 & 0.90642 & 1.61427 & 1.72178 & 4.51377 & 0.00000 & 0.89493 & 0.46635 & 0.01394 \\
\hline CA & 1.53553 & 0.35683 & 0.90642 & 1.61427 & 1.72178 & 4.51377 & 0.00000 & 0.89493 & 0.14995 & 0.01394 \\
\hline $\mathrm{O}$ & 0.53468 & 0.33827 & 0.90642 & 1.61427 & 1.72178 & 4.51377 & 0.00000 & 0.89493 & 0.03131 & 0.01394 \\
\hline $\mathrm{CT}$ & 1.53553 & 0.35683 & 0.90642 & 1.61427 & & 4.51377 & 0.00000 & 0.89493 & .14995 & 0.01394 \\
\hline $\mathrm{DE}$ & 1.53553 & 0.35683 & 0.90642 & 1.61427 & 1.72178 & 4.51377 & 0.00000 & 0.95000 & 0.14995 & 0.01394 \\
\hline FL & 1.48598 & 0.35683 & 0.90642 & 3.14408 & 1.72178 & 4.30807 & 0.00000 & 1.06578 & 0.06772 & 0.01000 \\
\hline$G A$ & 1.07063 & 0.28258 & 0.90642 & 1.61427 & 1.72178 & 4.51377 & 0.00000 & 0.89493 & 0.50000 & 0.01394 \\
\hline HI & 1.53553 & 0.35683 & 0.90642 & 1.61427 & 1.72178 & 4.51377 & 0.00000 & 0.89493 & 0.14995 & 0.01394 \\
\hline ID & 1.53553 & 0.35683 & 0.90642 & 1.61427 & 1.72178 & 4.51377 & 0.00000 & 0.89493 & 0.14995 & 0.01394 \\
\hline IL & 2.70687 & 0.23075 & 0.90642 & 1.61427 & 1.72178 & 4.51377 & 0.00000 & 0.89493 & 0.24445 & 0.01394 \\
\hline IN & 2.39468 & 0.24698 & 0.90642 & 1.61427 & 1.72178 & 4.51377 & 0.00000 & 0.89493 & 0.15868 & 0.01394 \\
\hline IA & 1.16898 & 0.32982 & 0.90642 & 1.61427 & 1.72178 & 5.52308 & 0.00000 & 0.89493 & 0.00607 & 0.01394 \\
\hline KS & 3.94230 & 0.35337 & 0.90642 & 1.61427 & 1.72178 & 4.38849 & 0.00000 & 0.89493 & 0.17568 & 0.01394 \\
\hline KY & 2.10738 & 0.30744 & 0.90642 & 3.28095 & 1.72178 & 4.51377 & 0.00000 & 0.89493 & 0.22587 & 0.01394 \\
\hline LA & 1.53553 & 0.34188 & 0.73408 & 1.61427 & 1.72178 & 4.51377 & 0.00000 & 0.27317 & 0.40900 & 0.01394 \\
\hline $\mathrm{ME}$ & 1.53553 & 0.35683 & 0.90642 & 1.61427 & 1.72178 & 4.51377 & 0.00000 & 0.89493 & 0.14995 & 0.01394 \\
\hline MD & 1.53553 & 0.35683 & 0.90642 & 1.61427 & 1.72178 & 4.51377 & 0.00000 & 0.89493 & 0.14995 & 0.01394 \\
\hline MA & 1.53553 & 0.35683 & 0.90642 & 1.61427 & 1.72178 & 4.51377 & 0.00000 & 1.00000 & 0.18563 & 0.01394 \\
\hline MI & 1.24906 & 0.28792 & 0.90642 & 1.61427 & 1.72178 & 5.91466 & 0.00000 & 0.86012 & 0.12412 & 0.01394 \\
\hline MN & 0.92025 & 0.45544 & 0.90642 & 1.61427 & 1.72178 & 6.21600 & 0.00000 & 0.89493 & 0.17070 & 0.01394 \\
\hline MS & 0.66092 & 0.30000 & 0.90642 & 1.61427 & 1.72178 & 4.51377 & 0.00000 & 3.00000 & 0.41902 & 0.01394 \\
\hline MO & 2.19901 & 0.29295 & 0.90642 & 1.61427 & 1.72178 & 3.68000 & 0.00000 & 0.89493 & 0.23704 & 0.01394 \\
\hline MT & 1.53553 & 0.64510 & 0.54058 & 1.61427 & 1.72178 & 4.51377 & 0.00000 & 0.89493 & 0.50000 & 0.01394 \\
\hline $\mathrm{NE}$ & 1.53553 & 0.31387 & 0.90642 & 1.61427 & 1.72178 & 4.51377 & 0.00000 & 0.89493 & 0.00280 & 0.01394 \\
\hline NV & 0.48912 & 0.37624 & 0.90642 & 1.61427 & 1.72178 & 4.51377 & 0.00000 & 0.89493 & 0.14995 & 0.01394 \\
\hline NH & 1.27203 & 0.35683 & 0.90642 & 1.61427 & 1.72178 & 4.51377 & 0.00000 & 0.96758 & 0.27000 & 0.01394 \\
\hline
\end{tabular}


TABLE 6 (Cont.)

\begin{tabular}{|c|c|c|c|c|c|c|c|c|c|c|}
\hline & BIT & SUB & LIG & SC & WC & PC & NG & RFO & DFO & JF \\
\hline$\overline{\mathrm{NJ}}$ & 1.84110 & 0.24000 & 0.90642 & 1.61427 & 1.72178 & 4.51377 & 0.00000 & 0.27887 & 0.09414 & 0.01394 \\
\hline NM & 1.53553 & 0.77066 & 0.90642 & 1.61427 & 1.72178 & 4.51377 & 0.00000 & 0.89493 & 0.00000 & 0.01394 \\
\hline NY & 1.98194 & 0.35683 & 0.90642 & 1.61427 & 1.72178 & 4.51377 & 0.00000 & 0.49495 & 0.12181 & 0.01394 \\
\hline NC & 0.88395 & 0.35683 & 0.90642 & 1.61427 & 1.72178 & 4.51377 & 0.00000 & 0.89493 & 0.15886 & 0.01394 \\
\hline ND & 1.53553 & 0.34086 & 0.76337 & 1.61427 & 1.72178 & 4.51377 & 0.00000 & 0.89493 & 0.34074 & 0.01394 \\
\hline $\mathrm{H}$ & 2.24325 & 0.24741 & 0.90642 & 0.92187 & 1.72178 & 4.51377 & 0.00000 & 0.89493 & 0.03600 & 0.01394 \\
\hline DK & 1.53553 & 0.31549 & 0.90642 & 1.61427 & 1.72178 & 4.51377 & 0.00000 & 0.89493 & 0.49185 & 0.01394 \\
\hline $\mathrm{R}$ & 1.53553 & 0.30722 & 0.90642 & 1.61427 & 1.72178 & 4.51377 & 0.00000 & 0.89493 & 0.10000 & 0.01394 \\
\hline PA & 1.53553 & 0.35683 & 0.90642 & 1.61427 & 1.72754 & 4.51377 & 0.00000 & 0.89493 & 0.14995 & 0.01394 \\
\hline RI & 1.53553 & 0.35683 & 0.90642 & 1.61427 & 1.72178 & 4.51377 & 0.00000 & 0.89493 & 0.14995 & 0.01394 \\
\hline SC & 1.25032 & 0.35683 & 0.90642 & 1.61427 & 1.72178 & 4.51377 & 0.00000 & 0.89493 & 0.16600 & 0.01394 \\
\hline SD & 1.53553 & 0.30252 & 0.90642 & 1.61427 & 1.72178 & 4.51377 & 0.00000 & 0.89493 & 0.14995 & 0.01394 \\
\hline$T N$ & 1.47505 & 0.28534 & 0.90642 & 1.61427 & 1.72178 & 4.51377 & 0.00000 & 0.89493 & 0.50000 & 0.01394 \\
\hline TX & 1.53553 & 0.28545 & 1.48026 & 1.61427 & 1.72178 & 4.51377 & 0.00000 & 0.89493 & 0.35093 & 0.01394 \\
\hline UT & 0.59183 & 0.35683 & 0.90642 & 0.56035 & 0.61829 & 4.51377 & 0.00000 & 0.89493 & 0.25290 & 0.01394 \\
\hline VT & 1.53553 & 0.35683 & 0.90642 & 1.61427 & 1.72178 & 4.51377 & 0.00000 & 0.89493 & 0.14995 & 0.01394 \\
\hline VA & 0.96706 & 0.35683 & 0.90642 & 1.61427 & 1.72178 & 4.51377 & 0.00000 & 0.20000 & 0.13946 & 0.01394 \\
\hline WA & 1.53553 & 0.35683 & 0.90642 & 1.61427 & 1.72178 & 4.51377 & 0.00000 & 0.89493 & 0.14995 & 0.01394 \\
\hline WV & 1.67058 & 0.41969 & 0.90642 & 1.61427 & 2.23463 & 4.51377 & 0.00000 & 0.89493 & 0.07500 & 0.20000 \\
\hline WI & 0.85987 & 0.29734 & 0.90642 & 1.61427 & 1.72178 & 5.46855 & 0.00000 & 0.89493 & 0.08440 & 0.01394 \\
\hline WY & 1.53553 & 0.49376 & 0.90642 & 1.61427 & 1.72178 & 4.51377 & 0.00000 & 0.89493 & 0.30696 & 0.01394 \\
\hline DC & 1.53553 & 0.35683 & 0.90642 & 1.61427 & 1.72178 & 4.51377 & 0.00000 & 0.89493 & 0.14995 & 0.01394 \\
\hline
\end{tabular}

TABLE 7 Ash contents (weight \%) of various fuels on an as-received basis in each state in year 2007

\begin{tabular}{|c|c|c|c|c|c|c|c|c|c|c|}
\hline & BIT & SUB & LIG & SC & WC & PC & NG & RFO & DFO & $\mathrm{JF}$ \\
\hline$\overline{\mathrm{AL}}$ & 9.23965 & 5.02859 & 12.31063 & 11.38480 & 44.85893 & 0.62183 & 0.00000 & 0.10845 & 0.00000 & 0.00208 \\
\hline AK & 10.31529 & 6.31810 & 12.31063 & 12.06472 & 44.85893 & 0.62183 & 0.00000 & 0.10845 & 0.01849 & 0.00208 \\
\hline $\mathrm{AZ}$ & 9.76459 & 11.42902 & 12.31063 & 12.06472 & 44.85893 & 0.62183 & 0.00000 & 0.10845 & 0.02498 & 0.00208 \\
\hline AR & 10.31529 & 4.83484 & 12.31063 & 12.06472 & 44.85893 & 0.62183 & 0.00000 & 0.10845 & 0.10154 & 0.00208 \\
\hline CA & 10.31529 & 6.31810 & 12.31063 & 12.06472 & 44.85893 & 0.62183 & 0.00000 & 0.10845 & 0.01849 & 0.00208 \\
\hline $\mathrm{CO}$ & 12.49913 & 5.61162 & 12.31063 & 12.06472 & 44.85893 & 0.62183 & 0.00000 & 0.10845 & 0.00000 & 0.00208 \\
\hline CT & 10.31529 & 6.31810 & 12.31063 & 12.06472 & 44.85893 & 0.62183 & 0.00000 & 0.10845 & 0.01849 & 0.00208 \\
\hline $\mathrm{DE}$ & 10.31529 & 6.31810 & 12.31063 & 12.06472 & 44.85893 & 0.62183 & 0.00000 & 0.00000 & 0.01849 & 0.00208 \\
\hline FL & 8.86764 & 6.31810 & 12.31063 & 8.36190 & 44.85893 & 0.66469 & 0.00000 & 0.03626 & 0.00000 & 0.00000 \\
\hline GA & 10.54668 & 4.65973 & 12.31063 & 12.06472 & 44.85893 & 0.62183 & 0.00000 & 0.10845 & 0.09984 & 0.00208 \\
\hline HI & 10.31529 & 6.31810 & 12.31063 & 12.06472 & 44.85893 & 0.62183 & 0.00000 & 0.10845 & 0.01849 & 0.00208 \\
\hline ID & 10.31529 & 6.31810 & 12.31063 & 12.06472 & 44.85893 & 0.62183 & 0.00000 & 0.10845 & 0.01849 & 0.00208 \\
\hline IL & 12.75097 & 4.72037 & 12.31063 & 12.06472 & 44.85893 & 0.62183 & 0.00000 & 0.10845 & 0.00000 & 0.00208 \\
\hline IN & 8.81044 & 4.90242 & 12.31063 & 12.06472 & 44.85893 & 0.62183 & 0.00000 & 0.10845 & 0.00000 & 0.00208 \\
\hline IA & 8.02722 & 5.10792 & 12.31063 & 12.06472 & 44.85893 & 0.32030 & 0.00000 & 0.10845 & 0.00000 & 0.00208 \\
\hline KS & 15.96029 & 5.07091 & 12.31063 & 12.06472 & 44.85893 & 0.19301 & 0.00000 & 0.10845 & 0.01010 & 0.00208 \\
\hline
\end{tabular}


TABLE 7 (Cont.)

\begin{tabular}{|c|c|c|c|c|c|c|c|c|c|c|}
\hline & BIT & SUB & LIG & SC & WC & PC & NG & RFO & DFO & JF \\
\hline$\overline{\mathrm{KY}}$ & 10.69417 & 5.52078 & 12.31063 & 11.64207 & 44.85893 & 0.62183 & 0.00000 & 0.10845 & 0.00000 & 0.00208 \\
\hline LA & 0.31529 & 5.11206 & 13.02603 & 12.06472 & 44.85893 & 0.62183 & 0.00000 & 32683 & 17050 & 00208 \\
\hline $\mathrm{ME}$ & 10.31529 & 6.31810 & 12.31063 & 12.06472 & 44.85893 & 0.62183 & 0.00000 & 0.10845 & 0.01849 & 0.00208 \\
\hline MD & 10.31529 & 6.31810 & 12.31063 & 12.06472 & 44.85893 & 0.62183 & 0.00000 & 0.10845 & 0.01849 & 0.00208 \\
\hline MA & 10.31529 & 6.31810 & 12.31063 & 12.06472 & 44.85 & 0.62183 & 0.00000 & 0.00000 & 0.00668 & 0.00208 \\
\hline MI & 9.04486 & 4.85436 & 12.31063 & 12.06472 & 44.85893 & 1.28831 & 0.00000 & 0.06516 & 0.01783 & 0.00208 \\
\hline $\mathrm{MN}$ & 8.03758 & 6.82404 & 12.31063 & 12.06472 & 44.85893 & 0.43711 & 0.00000 & 0.10845 & 0.01765 & 0.00208 \\
\hline MS & 9.49872 & 5.62637 & 12.31063 & 12.06472 & 44.85893 & 0.62183 & 0.00000 & 0.10000 & 0.00440 & 0.00208 \\
\hline MO & 8.82249 & 5.09978 & 12.31063 & 12.06 & 44.85 & 0.20000 & 0.00000 & 0.10845 & 0.00631 & 0.00208 \\
\hline MT & 10.31529 & 9.50765 & 8.73848 & 12.06472 & 44.85893 & 0.62183 & 0.00000 & 0.10845 & 0.00000 & 0.00208 \\
\hline $\mathrm{NE}$ & 10.31529 & 5.06339 & 12.31063 & 12.06472 & 44.85893 & 0.62183 & 0.00000 & 0.10845 & 0.00000 & 0.00208 \\
\hline NV & 9.51760 & 8.59164 & 12.31063 & 12.06472 & 44.85893 & 0.62183 & 0.00000 & 0.10845 & 0.01849 & 0.00208 \\
\hline $\mathrm{NH}$ & 6.55862 & 6.31810 & 12.31063 & 12.06472 & 44.85893 & 0.62183 & 0.00000 & 0.25283 & 0.07987 & 0.00208 \\
\hline NJ & 6.79610 & 4.70000 & 12.31063 & 12.06 & 44.85 & 0.62183 & 0.00000 & 0.62482 & 0.00075 & 0.00208 \\
\hline NM & 10.31529 & 22.05481 & 12.31063 & 12.06472 & 44.85893 & 0.62183 & 0.00000 & 0.10845 & 000 & 0.00208 \\
\hline NY & 8.53282 & 6.31810 & 12.31063 & 12.06472 & 44.85893 & 0.62183 & 0.00000 & 0.26162 & 0.10000 & 0.00208 \\
\hline NC & 11.94970 & 6.31810 & 12.31063 & 12.06472 & 44.858 & 0.62183 & 0.00000 & 0.10 & 0.00000 & 0.00208 \\
\hline ND & 103 & 4.92592 & 10.11939 & 12.06472 & 44.85893 & 0.62183 & 0.00000 & 0.10845 & 0.00000 & 0.00208 \\
\hline $\mathrm{OH}$ & 10.69418 & 5.33234 & 12.31063 & 13.86773 & 44.85893 & 0.62183 & 0.00000 & 0.10845 & 0.00000 & 0.00208 \\
\hline OK & 10.31529 & 5.12851 & 12.31063 & 12.06472 & 44.85893 & 0.62183 & 0.00000 & 0.10845 & 0.00000 & 0.00208 \\
\hline OR & 10.31529 & 4.71792 & 12.31063 & 12.06472 & 44.85893 & 0.62183 & 0.00000 & 0.1 & 0.10000 & 0.00208 \\
\hline PA & 10.31529 & 6.31810 & 12.31063 & 12.06472 & 45.3321 & 0.62183 & 0.00000 & 0.10845 & 0.01849 & 0.00208 \\
\hline RI & 10.31529 & 6.31810 & 12.31063 & 12.06472 & 44.85893 & 0.62183 & 0.00000 & 0.10845 & 0.01849 & 0.00208 \\
\hline SC & 10.00471 & 6.31810 & 12.31063 & 12.06472 & 44.85893 & 0.62183 & 0.00000 & 0.10845 & 0.00000 & 0.00208 \\
\hline SD & 10.31529 & 5.46386 & 12.31063 & 12.06472 & 44.85893 & 0.62183 & 0.00000 & 0.10845 & 0.01849 & 0.00208 \\
\hline TN & 9.89217 & 5.24092 & 12.31063 & 12.06472 & 44.85893 & 0.62183 & 0.00000 & 0.10845 & 0.00000 & 0.00208 \\
\hline TX & 10.31529 & 5.08348 & 20.21746 & 12.06472 & 44.85893 & 0.62183 & 0.00000 & 0.10845 & 0.00000 & 0.00208 \\
\hline UT & 12.59826 & 6.31810 & 12.31063 & 10.83886 & 46.83715 & 0.62183 & 0.00000 & 0.10845 & 0.00000 & 0.00208 \\
\hline VT & 10.31529 & 6.31810 & 12.31063 & 12.06472 & 44.85893 & 0.62183 & 0.00000 & 0.10845 & 0.01849 & 0.00208 \\
\hline VA & 10.14313 & 6.31810 & 12.31063 & 12.06472 & 44.85893 & 0.62183 & 0.00000 & 0.10000 & 0.06516 & 0.00208 \\
\hline WA & 10.31529 & 6.31810 & 12.31063 & 12.06472 & 44.85893 & 0.62183 & 0.00000 & 0.10845 & 0.01849 & 0.00208 \\
\hline WV & 11.79668 & 5.28451 & 12.31063 & 12.06472 & 38.79951 & 0.62183 & 0.00000 & 0.10845 & 0.01253 & 0.10000 \\
\hline WI & 8.50051 & 5.09154 & 12.31063 & 12.06472 & 44.85893 & 0.48613 & 0.00000 & 0.10845 & 0.01688 & 0.00208 \\
\hline WY & 10.31529 & 7.40841 & 12.31063 & 12.06472 & 44.858 & 0.62183 & 0.00000 & 0.10845 & 0.00000 & 0.00208 \\
\hline DC & 10.31529 & 6.31810 & 12.31063 & 12.06472 & 44.85893 & 0.62183 & 0.00000 & 0.10845 & 0.01849 & 0.00208 \\
\hline
\end{tabular}

Using data in Tables 2-7, the CO, VOC, $\mathrm{PM}_{10}$ and $\mathrm{PM}_{2.5}$ emission factors (in $\mathrm{g} / \mathrm{kWh}$ ) by fuel subtype and combustion technology per unit of net electricity generation output from each EGU are calculated using Equation (4). The emission factors for coal-fired, NG-fired, oil-fired and biomass-fired EGUs are combined to calculate the national average emission factors using the weighted average of net electricity generation by these EGUs. 


\subsection{EFFICIENCIES}

Since the LHVs of fuels are used by default in GREET to evaluate transportation fuels, we calculate the LHV-based energy efficiencies for EGUs employing the same fuel type and combustion technology, using Equation (9):

$$
\eta_{L H V, f, c t}=\frac{\text { elec.gen }_{f, c t} \times k W h 2 m m B t u}{\text { heatinput }_{f, c t} \times \frac{L H V_{f}}{H H V_{f}}} \times 100 \%
$$

where

$$
\begin{array}{ll}
\eta_{L H V, f, c t} & \text { is the LHV-based energy efficiency (\%) by fuel type and combustion } \\
& \text { technology; } \\
\text { elec.gen. } \text {. }_{f, c t} & \text { is the net electricity generation (kWh) by fuel type and combustion } \\
& \text { technology; } \\
k W h 2 m m B t u & \text { is the unit converter of per-kWh electricity to mmBtu, which is } 3412 \\
& \text { Btu per kWh; } \\
\text { heatinput }_{f, c t} & \text { is the heat input (mmBtu) by fuel type and combustion technology; and } \\
L H V_{f} \text { and } H H V_{f} & \text { are the LHV and HHV, respectively, of the fuel type. }
\end{array}
$$

Since the heat input of each EGU in eGRID is calculated on the basis of the HHV of the burning fuel on an as-received basis, the LHV-based heat input of each EGU for BIT, SUB, LIG, NG and biomass is estimated using Equation (10) (FR, 2007), with $H H V_{f}, m s t \%$, and $H \%$ measured via typical ultimate analyses of such fuels obtained from EPA (2006):

$$
L H V_{f}=H H V_{f}-10.55 \times(m s t \%+9 \times H \%)
$$

where

$L H V_{f}$ is the lower heating value in Btu/lb of fuel type $f$;

$H H V_{f} \quad$ is the higher heating value in Btu/lb of fuel type $f$;

$m s t \% \quad$ is the moisture weight percentage of fuel type $f$; and

$H \% \quad$ is the hydrogen weight percentage of fuel type $f$.

Owing to the lack of $\mathrm{H} \%$ data, the LHVs for RFO, DFO, JF and PC are not calculated using Equation (10). Instead, their LHVs are obtained from GREET 1_2011. For SC, WC, TDF, AB, MSB, OBS, OBL, WDL, OG, OTH, PUR, BLQ, LFG, KER, WO, DG and BFG, the $\frac{L H V_{f}}{H H V_{f}}$ 
ratios are approximated by that of the major fuel type with which they are associated (see section 2.2 above), as shown in Table 8.

\subsection{PROBABILITY DISTRIBUTION FUNCTIONS OF GHG AND CAP EMISSION FACTORS AND EFFICIENCIES}

To address the uncertainty associated with GHG and CAP emission estimation, which is partly due to variations in plant vintages and usages, the PDFs of GHG and CAP emission factors, as well as energy efficiencies of EGUs by fuel type and combustion technology, were developed on the basis of the performance of individual EGUs. The PDFs serve as functions that describe the relative likelihood for the emission factors and energy efficiencies as random variables to take on a given value by the integral of their own probability distributions, which reflect the fluctuation, variability and uncertainty of the real-world performance of EGUs. To be considered in the data set that was used to develop the PDF, the energy efficiencies had to be both positive and not higher than $45 \%, 45 \%, 60 \%$ and $45 \%$ for boilers, CTs, combined-cycle (CC) plants and ICEs, respectively. The potential outliers among GHG and CAP emission factors for individual EGUs and the corresponding efficiencies were detected using the modified Z-score defined by Equation (2), and EGUs associated with these outliers were removed from the data set before the PDF was developed.

TABLE $8 \quad \frac{L H V_{f}}{H H V_{f}}$ ratios, on an as-received basis, of various fuels

burned by EGUs

\begin{tabular}{llllllll}
\hline & $\frac{L H V_{f}}{H H V_{f}}$ & & $\frac{L H V_{f}}{H H V_{f}}$ & & $\frac{L H V_{f}}{H H V_{f}}$ & & $\frac{L H V_{f}}{H H V_{f}}$ \\
\cline { 2 - 7 } & & & & & & \\
BIT & $0.95332^{\mathrm{a}}$ & NG & $0.90133^{\mathrm{a}}$ & RFO & $0.93500^{\mathrm{b}}$ & WDS & $0.89408^{\mathrm{c}}$ \\
SUB & $0.93036^{\mathrm{a}}$ & LFG & $0.90133^{\mathrm{a}}$ & DFO & $0.93500^{\mathrm{b}}$ & WDL & $0.83922^{\mathrm{d}}$ \\
LIG & $0.91138^{\mathrm{a}}$ & BFG & $0.90133^{\mathrm{a}}$ & JF & $0.93500^{\mathrm{b}}$ & MSB & $0.89408^{\mathrm{c}}$ \\
SC & $0.95332^{\mathrm{a}}$ & DG & $0.90133^{\mathrm{a}}$ & KER & $0.93500^{\mathrm{b}}$ & BLQ & $0.83922^{\mathrm{d}}$ \\
WC & $0.95332^{\mathrm{a}}$ & OG & $0.90133^{\mathrm{a}}$ & WO & $0.93500^{\mathrm{b}}$ & AB & $0.83922^{\mathrm{d}}$ \\
PC & $0.94242^{\mathrm{b}}$ & PUR & $0.90133^{\mathrm{a}}$ & & & OBS & $0.89408^{\mathrm{c}}$ \\
TDF & $0.95332^{\mathrm{a}}$ & OTH & $0.90133^{\mathrm{a}}$ & & & OBL & $0.83922^{\mathrm{d}}$ \\
\hline
\end{tabular}

a Based on the ultimate analysis of coal properties from EPA (2006).

b From GREET1-2011.

c Based on the ultimate analysis of biomass properties from EPA (2007b), assuming a moisture content of $20 \%$.

d Based on the ultimate analysis of biomass properties from EPA (2007b), assuming a moisture content of $45 \%$. 
Upon detection and exclusion of outliers, a toolbox called EasyFit Professional (developed by Mathwaves) was used to develop a number of PDFs for each of the GHG and CAP emission factors, as well as efficiencies based on multiple commonly used statistical goodness-of-fit criteria (e.g., Kolmogorov Smirnov and Anderson Darling). We used the calculated emission factors of individual EGUs for each fuel/combustion technology as sample data values and used the net electricity generation of each EGU as the corresponding probability density value. Subsequently, the best-fit PDF based on the goodness-of-fit criteria was selected from a gallery of built-in PDFs in EasyFit and in GREET (Subramanyan and Diwekar, 2005). Once developed, the PDFs were used to quantify the uncertainty associated with each GHG and CAP emission factor and efficiency of EGUs. 


\section{RESULTS}

\subsection{DATA QUALITY EVALUATION}

\subsubsection{Detection of Outliers}

By applying the efficiency thresholds, the Z-scores, and the "1.96 standard deviations" criteria defined in Section 2.1, a number of potential outliers by fuel type and combustion technology are ruled out, as shown in Table 9, before the remaining good-quality data are processed for the GHG and CAP emission factors and the efficiencies.

\section{TABLE 9 Number of outliers detected by fuel type and combustion technology}

\begin{tabular}{|c|c|c|c|c|c|c|c|c|c|c|}
\hline \multirow{2}{*}{$\begin{array}{c}\text { Fuel type/ } \\
\text { com- } \\
\text { bustion } \\
\text { tech- } \\
\text { nology }\end{array}$} & \multirow{2}{*}{$\begin{array}{l}\text { No. of } \\
\text { outliers by } \\
\text { efficiency } \\
\text { thresholds/ } \\
\text { total no. of } \\
\text { EGUs }\end{array}$} & \multicolumn{9}{|c|}{ No. of outliers by Z-scores and standard deviations/total no. of EGUs } \\
\hline & & $\mathrm{CO}_{2}$ & $\mathrm{CH}_{4}$ & $\mathrm{~N}_{2} \mathrm{O}$ & $\mathrm{NO}_{\mathrm{x}}$ & $\mathrm{SO}_{\mathrm{x}}$ & $\mathrm{PM}_{10}$ & $\mathrm{PM}_{2.5}$ & VOC & $\mathrm{CO}$ \\
\hline Coal/BLR & $4 / 419$ & $18 / 415$ & $18 / 415$ & $12 / 415$ & $21 / 415$ & $6 / 415$ & $29 / 415$ & $27 / 415$ & $21 / 415$ & $15 / 415$ \\
\hline NG/BLR & $48 / 257$ & $16 / 209$ & $21 / 209$ & $4 / 209$ & $17 / 209$ & $51 / 209$ & $2 / 209$ & $2 / 209$ & $2 / 209$ & $2 / 209$ \\
\hline NG/CT & $151 / 569$ & $33 / 418$ & $38 / 418$ & $7 / 418$ & $43 / 418$ & $91 / 418$ & $6 / 418$ & $6 / 418$ & $6 / 418$ & $6 / 418$ \\
\hline NG/CC & $47 / 275$ & $31 / 228$ & $31 / 228$ & $31 / 228$ & $40 / 228$ & $60 / 228$ & $29 / 228$ & $29 / 228$ & $29 / 228$ & $1 / 228$ \\
\hline NG/ICE & $34 / 262$ & $16 / 228$ & $7 / 228$ & $7 / 228$ & $7 / 228$ & $7 / 228$ & $7 / 228$ & $7 / 228$ & $7 / 228$ & $7 / 228$ \\
\hline Oil/BLR & $0 / 28$ & $2 / 28$ & $0 / 28$ & $0 / 28$ & $0 / 28$ & $2 / 28$ & $1 / 28$ & $1 / 28$ & $2 / 28$ & $0 / 28$ \\
\hline $\mathrm{Oil} / \mathrm{CT}$ & $7 / 146$ & 2/139 & $14 / 139$ & $14 / 139$ & 17/139 & 8/139 & $14 / 139$ & $2 / 139$ & 6/139 & 6/139 \\
\hline Oil/ICE & $33 / 424$ & $61 / 381$ & $61 / 381$ & 26/381 & $24 / 381$ & $19 / 381$ & $31 / 381$ & $26 / 381$ & $35 / 381$ & $63 / 381$ \\
\hline $\begin{array}{l}\text { Biomass/ } \\
\text { BLR }\end{array}$ & $0 / 87$ & $3 / 87$ & $3 / 87$ & $2 / 87$ & $7 / 87$ & $5 / 87$ & $4 / 87$ & $3 / 87$ & $3 / 87$ & $1 / 87$ \\
\hline
\end{tabular}

There are quite a few outliers, particularly for NG-fired and oil-fired EGUs, as shown in Table 9. Therefore, the detection and removal of such outliers is necessary and substantially improves the quality of the data used and the final results of this report.

\subsubsection{Comparison of GHG and CAP Emissions with EPA's NEI Data}

The accuracy of the GHG and CAP emission factors per unit electricity generated is largely dependent on the accuracy of the estimation of GHG and CAP emissions. Thus, to evaluate the data quality of our calculated emission factors, the total GHG and CAP emissions calculated 
from this study were compared with EPA's Inventory of U.S. Greenhouse Gas Emissions and Sinks (EPA, 2009b) and EPA's National Emission Inventory (NEI) Air Pollutant Emissions Trends Data (EPA, 2011d), as shown in Table 10.

$\begin{array}{llllllllll}\text { TABLE } 10 & \begin{array}{l}\text { Comparison of total GHG and CAP emissions (thousand tons) calculated in } \\ \text { the present study for the electric power sector with EPA's NEI data for the } \\ \text { year 2007 }\end{array} \\ \begin{array}{lllllllllll}\mathrm{CO}_{2} & \mathrm{CH}_{4} & \mathrm{~N}_{2} \mathrm{O} & \mathrm{PM}_{10} & \mathrm{PM}_{2.5} & \mathrm{VOC} & \mathrm{CO} & \mathrm{NO}_{\mathrm{x}} & \mathrm{SO}_{\mathrm{x}} \\ \hline \begin{array}{l}\text { This study } \\ \text { NEI 2007 }\end{array} & 2440542^{*} & 47^{*} & 37^{*} & 660 & 376 & 44 & 716 & 3343^{*} & 8913^{*} \\ \begin{array}{l}\text { Percentage } \\ \text { difference }\end{array} & 1.10 & 43 & 33 & 479 & 398 & 44 & 699 & 3223 & 8472 \\ \hline\end{array}\end{array}$

*Based on eGRID 2010.

Table 10 shows that with the exception of $\mathrm{CH}_{4}$ and $\mathrm{PM}_{10}$ emissions, the GHG and CAP emissions from this study agree well with the EPA's NEI estimates. Both eGRID and NEI estimated $\mathrm{CH}_{4}$ emissions by multiplying the fuel-specific heat input in MMBtu by appropriate Tier 2 technology- and fuel-specific emission factors from the Intergovernmental Panel on Climate Change, such as $1.0 \mathrm{~g} / \mathrm{GJ}$ for coal boiler combustion, $3.0 \mathrm{~g} / \mathrm{GJ}$ for petroleum boiler combustion, $1.0 \mathrm{~g} / \mathrm{GJ}$ for natural gas boiler combustion, and $30.0 \mathrm{~g} / \mathrm{GJ}$ for wood boiler combustion, which are also the default $\mathrm{CH}_{4}$ emission factors in GREET (except for wood boiler combustion). The emission differences shown in Table 10 are ascribed to two factors. The first is the difference in fuel-specific heat input. The NEI obtained the heat input data from the EPA's Acid Rain Program Dataset (ARPD, EPA 2009c), whereas eGRID obtained the heat input data from both the EPA's CAMD continuously monitored data, which is basically the same as the ARPD, and the EIA 923 heat input data when the former are not available. As the NEI does not mention where the heat input data are obtained for those power plants that are not included in the ARPD, this indicates that eGRID was likely to account for a more complete list of power plants than the NEI, and therefore the $\mathrm{CH}_{4}$ emissions estimated by eGRID were higher than the NEI estimation. The second reason is that the NEI data for year 2007 are a simple interpolation between the NEI 2005 data and the NEI 2008 data, which could have higher uncertainty than the emissions originally estimated with eGRID. Therefore, we believe the observed difference is plausible and the $\mathrm{CH}_{4}$ estimation from eGRID is credible.

We could not find the source of the $\mathrm{PM}_{10}$ discrepancy. However, we note that the NEI PM 10 and $\mathrm{PM}_{2.5}$ data for 2007 were simple interpolations between the 2005 and 2008 data. Moreover, the $\mathrm{PM}_{2.5} / \mathrm{PM}_{10}$ emission ratio for EPA's NEI is much higher, at 83.1\%, than ours at $57.0 \%$. Upon checking the AP-42 PM emission factors for coal-fired EGUs, we found the $\mathrm{PM}_{2.5} / \mathrm{PM}_{10}$ emission ratios to be $26.1 \%, 10.3 \%, 71.8 \%, 43.3 \%$ and $57.6 \%$ for uncontrolled, cyclone- 
controlled, scrubber-controlled, ESP-controlled and baghouse-controlled facilities, respectively. Therefore, we concluded that NEI's $\mathrm{PM}_{2.5} / \mathrm{PM}_{10}$ emission ratio of $83.1 \%$ is less realistic than ours, especially when a large share (approximately 50\%) of the total electric generation in the U.S. comes from coal-fired EGUs. Furthermore, our estimates of $\mathrm{PM}_{10}$ and $\mathrm{PM}_{2.5}$ are based on rigorous evaluation of fuel types and specifications, combustion technologies, emission control technologies, unit-level FGD deployment rate, and the recommended 40/60 and 20/80 split of FPM and CPM for $\mathrm{PM}_{10}$ and $\mathrm{PM}_{2.5}$, respectively. Moreover, our $\mathrm{PM}_{10}$ emissions estimates incorporate the high $\mathrm{PM}_{10}$ emission contributions from WC, SC, WDS, MSB, BLQ, and PetCoke combustion, which together account for $31.6 \%$ of the total $\mathrm{PM}_{10}$ emissions despite their low contribution to the total generation mix (4.3\%). The higher $\mathrm{PM}_{10}$ emissions from EGUs that employ these fuels are due to the absence of PM control devices (e.g., baghouse or electrostatic precipitator), as indicated in the EPA's CAMD database.

\subsubsection{Carbon Intensities by Fuel Type}

Fuel quantities consumed are calculated on the basis of plant-level heat input, which could involve errors for multiple-fuel-burning EGUs because of the lumping of the minor fuel types with the primary fuel type. To reduce this potential bias, the plant-level carbon intensities (CIs) of the primary fuel types are calculated using Equation (11), and those with significant bias are recognized using the modified Z-score approach and removed as outliers.

$$
C I=\frac{\frac{12}{44} \times E_{\mathrm{CO}_{2}}+\frac{12}{28} \times E_{\mathrm{CO}}+\frac{12}{16} \times E_{\mathrm{CH}_{4}}+0.85 \times E_{\mathrm{VOC}}}{Q}
$$

where

$\begin{array}{ll}C I & \text { is carbon intensity; } \\ E_{\mathrm{CO}_{2}} & \text { is the } \mathrm{CO}_{2} \text { emissions, in tons; } \\ E_{\mathrm{CO}} & \text { is the CO emissions, in tons; } \\ E_{\mathrm{CH}_{4}} & \text { is the } \mathrm{CH}_{4} \text { emissions, in tons; } \\ E_{\mathrm{VOC}} & \text { is the VOC emissions, in tons; and } \\ Q & \text { is the quantities of fuels consumed, in tons. }\end{array}$

Table 11 summarizes the percentages of CI outliers detected by fuel type and combustion technology for multiple-fuel-burning EGUs on the basis of their nameplate capacities. With the removal of these detected outliers, the potential bias associated with our methodology is minimized. 
TABLE 11 Percentage of CI outliers detected by fuel type and generation technology

\begin{tabular}{llll}
\hline Fuel type & Combustion technology & $\begin{array}{l}\text { Outlier no. (Total } \\
\text { no. of EGUs) }\end{array}$ & $\begin{array}{l}\text { Outlier nameplate } \\
\text { capacity share (\%) }\end{array}$ \\
\hline BIT & Boiler & $14(388)$ & 0.76 \\
SUB & Boiler & $6(198)$ & 1.80 \\
LIG & Boiler & $0(16)$ & 0 \\
NG & Boiler & $1(228)$ & 0.0050 \\
& Combined-Cycle Plant & $1(424)$ & 0.000088 \\
& Combustion Turbine & $3(609)$ & 0.0042 \\
& Internal Combustion Engine & $3(157)$ & 0.0033 \\
RFO & Boiler & $2(37)$ & 0.32 \\
DFO & Internal Combustion Engine & $21(489)$ & 1.53 \\
& Combustion Turbine & $2(127)$ & 3.90 \\
JF & Combustion Turbine & $0(6)$ & 0 \\
\hline
\end{tabular}

\subsection{NATIONAL AVERAGE GHG AND CAP EMISSION FACTORS AND EFFICIENCIES BY FUEL TYPE AND GENERATION TECHNOLOGY}

The national-average GHG and CAP emission factors, LHV-based efficiencies, and generation technology shares (determined by the ratio of their generated electricity to the total generated electricity) for non-CHP EGUs are summarized in Table 12. Aggregating the generation from all fuel subtypes for each fuel gives the GHG and CAP emission factors, as well as the efficiencies, shown in Table 13. The zero $\mathrm{CO}_{2}$ emission factors for biomass, including WDS, WDL, BLQ, $\mathrm{AB}, \mathrm{MSB}, \mathrm{OBS}$, and $\mathrm{OBL}$, reflect the fact that the carbon in biomass is originally from the atmosphere, and thus the net $\mathrm{CO}_{2}$ emission to the atmosphere is zero. 
TABLE 12 GHG and CAP emission factors (g/kWh) by fuel subtype and combustion technology for the electricity power sector in the U.S.

\begin{tabular}{|c|c|c|c|c|c|c|c|c|c|c|c|c|}
\hline & $\begin{array}{l}\text { Fuel subtype } \\
\text { (share) }\end{array}$ & $\begin{array}{c}\text { Combustion } \\
\text { technology } \\
\text { (share) }\end{array}$ & $\begin{array}{l}\text { Effi- } \\
\text { ciency }\end{array}$ & $\mathrm{CO}_{2}$ & $\mathrm{CH}_{4}$ & $\mathrm{~N}_{2} \mathrm{O}$ & $\mathrm{NO}_{\mathrm{x}}$ & $\mathrm{SO}_{\mathrm{x}}$ & $\mathrm{PM}_{10}$ & $\mathrm{PM}_{2.5}$ & VOC & $\mathrm{CO}$ \\
\hline \multirow[t]{7}{*}{ Coal } & BIT (50.3\%) & BLR (100.0\%) & $35.2 \%$ & 939.7 & 0.01078 & 0.01583 & 1.46424 & 4.73676 & 0.21297 & 0.17863 & 0.01166 & 0.09826 \\
\hline & SUB (40.2\%) & BLR (100.0\%) & $33.6 \%$ & 1009.9 & 0.01148 & 0.01711 & 1.33016 & 2.83006 & 0.04787 & 0.02596 & 0.01451 & 0.12215 \\
\hline & LIG (4.4\%) & BLR (100.0\%) & $34.4 \%$ & 1085.1 & 0.01161 & 0.01723 & 1.28867 & 3.62487 & 0.23722 & 0.23652 & 0.02304 & 0.14917 \\
\hline & SC (4.6\%) & BLR (100.0\%) & $37.4 \%$ & 887.4 & 0.01009 & 0.01509 & 1.09157 & 6.10972 & 0.17456 & 0.14437 & 0.00793 & 0.06608 \\
\hline & WC $(0.2 \%)$ & BLR (100.0\%) & $32.3 \%$ & 1044.4 & 0.01171 & 0.01753 & 0.85223 & 4.32689 & 2.15083 & 0.60515 & 0.02934 & 0.10478 \\
\hline & PC (0.3\%) & BLR (100.0\%) & $33.0 \%$ & 1003.4 & 0.01164 & 0.01515 & 0.94548 & 2.40568 & 0.96453 & 0.54942 & 0.00862 & 0.07392 \\
\hline & TDF (0.01\%) & BLR (100.0\%) & $22.2 \%$ & 968.4 & 0.50346 & 0.06707 & 5.73916 & 19.6564 & 3.90010 & 1.10953 & 0.01591 & 0.13262 \\
\hline \multirow[t]{14}{*}{ NG } & NG (99.1\%) & BLR (13.4\%) & $31.9 \%$ & 631.2 & 0.01253 & 0.00143 & 0.83724 & 0.00449 & 0.03528 & 0.03528 & 0.02714 & 0.40760 \\
\hline & & CT (5.9\%) & $32.9 \%$ & 622.6 & 0.01237 & 0.00134 & 0.35089 & 0.00648 & 0.03435 & 0.03435 & 0.01093 & 0.42682 \\
\hline & & CC (80.5\%) & $49.8 \%$ & 408.7 & 0.00793 & 0.00080 & 0.06295 & 0.00203 & 0.00083 & 0.00083 & 0.00170 & 0.02797 \\
\hline & & ICE (0.2\%) & $37.6 \%$ & 530.9 & 0.01128 & 0.00124 & 5.45417 & 0.03715 & 0.20483 & 0.20483 & 0.48195 & 1.65775 \\
\hline & LFG (0.8\%) & BLR (15.1\%) & $30.7 \%$ & 0.8 & 0.00003 & 0.00001 & 2.05681 & 0.00015 & 0.09433 & 0.09433 & 0.06575 & 1.12598 \\
\hline & & CT (19.0\%) & $24.3 \%$ & 0.0 & 0.00000 & 0.00000 & 0.79253 & 0.00000 & 0.17581 & 0.17581 & 0.09201 & 3.11421 \\
\hline & & CC (10.9\%) & $30.3 \%$ & 140.5 & 0.00109 & 0.00011 & 0.29449 & 0.00107 & 0.14097 & 0.14097 & 0.07378 & 0.04765 \\
\hline & & ICE (55.0\%) & $29.9 \%$ & 6.5 & 0.00091 & 0.00013 & 2.42821 & 0.00250 & 0.57210 & 0.57210 & 1.34612 & 4.63018 \\
\hline & BFG (0.02\%) & BLR (100.0\%) & $12.0 \%$ & 1491.0 & 0.02972 & 0.00297 & 2.44007 & 0.44474 & 0.03233 & 0.03233 & 0.00168 & 0.05150 \\
\hline & DG $(0.01 \%)$ & BLR (21.1\%) & $17.6 \%$ & 200.4 & 0.00404 & 0.00041 & 2.30531 & 0.00846 & 0.10728 & 0.10728 & 0.07764 & 1.18570 \\
\hline & & ICE (78.9\%) & $25.7 \%$ & 9.1 & 0.00039 & 0.00008 & 1.58177 & 0.01188 & 0.47648 & 0.47648 & 1.12112 & 3.85626 \\
\hline & OG (0.04\%) & BLR (26.0\%) & $18.2 \%$ & 1100.3 & 0.02196 & 0.00220 & 18.1677 & 0.35812 & 0.77565 & 0.77565 & 0.56133 & 8.57301 \\
\hline & & CT (9.8\%) & $13.7 \%$ & 1463.1 & 0.02916 & 0.00292 & 1.15154 & 0.04448 & 0.08261 & 0.08261 & 0.02629 & 1.02637 \\
\hline & & ICE (64.2\%) & $10.1 \%$ & 1980.9 & 0.03949 & 0.00395 & 2.76143 & 0.06316 & 0.88853 & 0.88853 & 2.09066 & 7.19114 \\
\hline \multirow[t]{4}{*}{ Oil } & RFO (89.4\%) & BLR (100.0\%) & $32.8 \%$ & 791.1 & 0.03058 & 0.00590 & 1.35301 & 3.29910 & 0.13979 & 0.11591 & 0.02555 & 0.02557 \\
\hline & DFO (8.0\%) & BLR (2.4\%) & $22.8 \%$ & 1179.3 & 0.05075 & 0.01018 & 1.79151 & 4.81600 & 0.11794 & 0.07948 & 0.03897 & 0.25638 \\
\hline & & CT (67.9\%) & $31.1 \%$ & 869.3 & 0.03683 & 0.00739 & 2.74862 & 0.67096 & 0.31780 & 0.06812 & 0.00264 & 0.02123 \\
\hline & & ICE (29.7\%) & $34.8 \%$ & 768.6 & 0.03288 & 0.00662 & 9.70863 & 0.82745 & 0.09806 & 0.04777 & 0.01968 & 0.08508 \\
\hline
\end{tabular}


TABLE 12 (Cont.)

\begin{tabular}{lllllllllllll}
\hline $\begin{array}{l}\text { Fuel subtype } \\
\text { (share) }\end{array}$ & $\begin{array}{l}\text { Combustion } \\
\text { technology } \\
\text { (share) }\end{array}$ & $\begin{array}{l}\text { Effi- } \\
\text { ciency }\end{array}$ & CO2 & CH4 & N2O & NOx & SOx & PM10 & PM2.5 & VOC & CO \\
\hline JF (2.4\%) & CT (100.0\%) & $37.9 \%$ & 704.8 & 0.03047 & 0.00611 & 1.33929 & 1.24463 & 0.26848 & 0.06461 & 0.00011 & 0.01441 \\
WO (0.01\%) & ICE (100.0\%) & $41.5 \%$ & 653.2 & 0.27500 & 0.03666 & 5.39524 & 0.28884 & 0.00340 & 0.00275 & 0.00052 & 0.00339 \\
BER (0.2\%) & CT (100.0\%) & $25.4 \%$ & 1051.6 & 0.04549 & 0.00912 & 1.64269 & 0.46794 & 0.40203 & 0.40203 & 0.02607 & 0.02151 \\
Biomass & WDS (37.6\%) & BLR (100.0\%) & $22.5 \%$ & 0.0 & 0.51546 & 0.06932 & 1.74266 & 0.18924 & 2.51730 & 2.34353 & 0.12970 & 4.57770 \\
& MSB (59.0\%) & BLR (100.0\%) & $20.9 \%$ & 0.0 & 0.57671 & 0.07684 & 7.04769 & 19.7043 & 3.12365 & 2.21224 & 0.14085 & 4.97133 \\
BLQ (2.1\%) & BLR (100.0\%) & $8.5 \%$ & 0.0 & 0.38503 & 0.10657 & 3.62878 & 8.93050 & 1.22254 & 0.30564 & 0.05557 & 0.35805 \\
AB (0.7\%) & BLR (100.0\%) & $30.6 \%$ & 0.0 & 0.42090 & 0.05608 & 0.60302 & 0.04020 & 2.27335 & 1.61004 & 0.10251 & 3.61807 \\
OBS (0.6\%) & BLR (100.0\%) & $15.3 \%$ & 0.0 & 0.79178 & 0.10549 & 1.86746 & 1.29146 & 4.27651 & 3.02872 & 0.19284 & 6.80612 \\
OBL (0.02\%) & BLR (100.0\%) & $37.7 \%$ & 0.0 & 0.03419 & 0.00686 & 6.63204 & 0.05393 & 1.84659 & 1.30780 & 0.08327 & 2.93887 \\
\hline
\end{tabular}

Note: BLR, CT, CC and ICE represent boilers, combustion turbines, combined-cycle plants and internal combustion engines, respectively. 
TABLE 13 GHG and CAP emission factors ( $\mathrm{g} / \mathrm{kWh}$ ) by fuel type and combustion technology for the electricity power sector in the U.S.

\begin{tabular}{|c|c|c|c|c|c|c|c|c|c|c|c|c|}
\hline & $\begin{array}{l}\text { Com- } \\
\text { bustion } \\
\text { tech- } \\
\text { nology }\end{array}$ & Efficiency & $\begin{array}{l}\text { Tech- } \\
\text { nology } \\
\text { share }\end{array}$ & $\mathrm{CO}_{2}$ & $\mathrm{CH}_{4}$ & $\mathrm{~N}_{2} \mathrm{O}$ & $\mathrm{NO}_{\mathrm{x}}$ & $\mathrm{SO}_{\mathrm{x}}$ & $\mathrm{PM}_{10}$ & $\mathrm{PM}_{2.5}$ & VOC & $\mathrm{CO}$ \\
\hline \multirow[t]{5}{*}{ Coal } & BLR & $34.5 \%$ & $100.0 \%$ & 973.5 & 0.0111 & 0.0164 & 1.3843 & 3.9377 & 0.1504 & 0.1182 & 0.0133 & 0.1092 \\
\hline & IGCC $^{a}$ & $42.2 \%$ & $0.0 \%$ & 716.6 & NA & NA & 0.2150 & 0.0044 & 0.0258 & NA & NA & NA \\
\hline & IGCC $^{\mathrm{b}}$ & $43.8 \%$ & $0.0 \%$ & 653.6 & NA & NA & 0.1610 & 0.1411 & 0.0231 & NA & 0.0054 & 0.0984 \\
\hline & IGCC $^{c}$ & $43.0 \%$ & $0.0 \%$ & 699.0 & NA & NA & 0.1479 & 0.0404 & 0.0236 & NA & 0.0059 & 0.1007 \\
\hline & IGCC $^{\mathrm{d}}$ & $43.0 \%$ & $0.0 \%$ & 718.5 & NA & NA & 0.1701 & 0.0680 & 0.0240 & NA & 0.0059 & 0.1021 \\
\hline \multirow[t]{4}{*}{ NG } & BLR & $31.9 \%$ & $13.5 \%$ & 625.4 & 0.0124 & 0.0014 & 0.8608 & 0.0048 & 0.0364 & 0.0364 & 0.0279 & 0.4201 \\
\hline & CT & $32.6 \%$ & $6.0 \%$ & 600.8 & 0.0119 & 0.0013 & 0.3616 & 0.0062 & 0.0394 & 0.0394 & 0.0138 & 0.5231 \\
\hline & CC & $49.8 \%$ & $79.9 \%$ & 408.7 & 0.0079 & 0.0008 & 0.0629 & 0.0020 & 0.0008 & 0.0008 & 0.0017 & 0.0281 \\
\hline & ICE & $29.0 \%$ & $0.6 \%$ & 208.3 & 0.0049 & 0.0005 & 3.1366 & 0.0132 & 0.4868 & 0.4868 & 1.1454 & 3.9398 \\
\hline \multirow[t]{3}{*}{ Oil } & BLR & $32.8 \%$ & $89.6 \%$ & 791.1 & 0.0306 & 0.0059 & 1.3530 & 3.2991 & 0.1398 & 0.115 & 0.0256 & 0.1682 \\
\hline & CT & $32.7 \%$ & $8.0 \%$ & 822.9 & 0.0351 & 0.0070 & 2.2708 & 0.5939 & 0.3045 & 0.0740 & 0.0021 & 0.0178 \\
\hline & ICE & $34.8 \%$ & $2.4 \%$ & 759.1 & 0.0352 & 0.0069 & 9.5561 & 0.8121 & 0.0958 & 0.0467 & 0.0192 & 0.0816 \\
\hline \multirow[t]{2}{*}{ Biomass } & BLR & $20.8 \%$ & $100.0 \%$ & & 0.5509 & 0.0748 & 5.0041 & 12.977 & 2.8757 & 2.2239 & 0.1352 & 4.7373 \\
\hline & IGCC & $40.0 \%^{\mathrm{e}}$ & $0.0 \%$ & 0.0 & $\begin{array}{l}\text { Negli- } \\
\text { gible }^{f}\end{array}$ & $\begin{array}{l}\text { Negli- } \\
\text { gible }^{f}\end{array}$ & $0.078^{\mathrm{e}}$ & $0.322^{\mathrm{e}}$ & $0.024^{\mathrm{e}}$ & $0.012^{\mathrm{g}}$ & $0.070^{\mathrm{f}}$ & $0.071^{\mathrm{f}}$ \\
\hline
\end{tabular}

Note: IGCC represents integrated gasification combined cycle, and NA denotes not available.

a Data from NETL (2010).

b Data from EPA (2006), representing BIT-fired IGCC plants.

c Data from EPA (2006), representing SUB-fired IGCC plants.

d Data from EPA (2006), representing LIG-fired IGCC plants.

e From GREET 1-2011.

f From Mann (2001).

$\mathrm{g}$ Calculated from the ratio of $\mathrm{PM}_{10}$ and $\mathrm{PM}_{2.5}$ emission factors for biomass IGCC plants in GREET 1-2011. 
It needs to be mentioned that the $\mathrm{CO}_{2}$ emission factors calculated from the methodology described in Section 2.1 are not used by GREET, which actually uses an alternative approach based on the carbon content of fuels, assuming a 100\% carbon oxidation rate (Wang, 1999). In comparison with the $\mathrm{CO}_{2}$ emission factor $(973.5 \mathrm{~g} / \mathrm{kWh})$ for coal-fired power plants calculated from eGRID2010, the $\mathrm{CO}_{2}$ emission factor $(1084 \mathrm{~g} / \mathrm{kWh})$ calculated by the previous version of GREET is about $11.4 \%$ higher, which indicates that the previous coal property parameters, particularly the carbon and heat content of various subtypes of coal in GREET, might be inaccurate for recent years. So we also made an effort to update the coal property parameters in this study: we used EIA's unit-level fuel quality data (EIA-423) to update the HHVs of various subtypes of coal, including BIT, SUB, LIG, SC, WC, PC, and TDF, and we used USGS's Coal Quality database (USGS, 2006) to update the carbon contents of the three major subtypes of coal (BIT, SUB and LIG) on a state coal production weighted-average basis, taking into account the interstate variation in coal properties, and to convert the EIA-based HHVs to LHVs based on the LHV/HHV ratios by coal subtype, also calculated on the basis of the USGS database. With the updated coal property parameters, GREET calculates a new $\mathrm{CO}_{2}$ emission factor of $989 \mathrm{~g} / \mathrm{kWh}$ for coal-fired power plants, which is an $8.8 \%$ reduction compared to the previous $\mathrm{CO}_{2}$ emission factor. Consequently, this new $\mathrm{CO}_{2}$ emission factor is much more consistent with the flue gas measurement-based number ( $973.5 \mathrm{~g} / \mathrm{kWh}$ ) from eGRID.

\subsection{REGIONAL GHG AND CAP EMISSION FACTORS AND EFFICIENCIES BY FUEL TYPE AND GENERATION TECHNOLOGY}

GHG and CAP emission factors, efficiencies, and combustion technology shares in the ten North American Electric Reliability Council (NERC) regions shown in Figure 1 are summarized in Table 14. These estimates facilitate life cycle analysis of the GHG and CAP emissions of various vehicle/fuel systems at the regional level. 


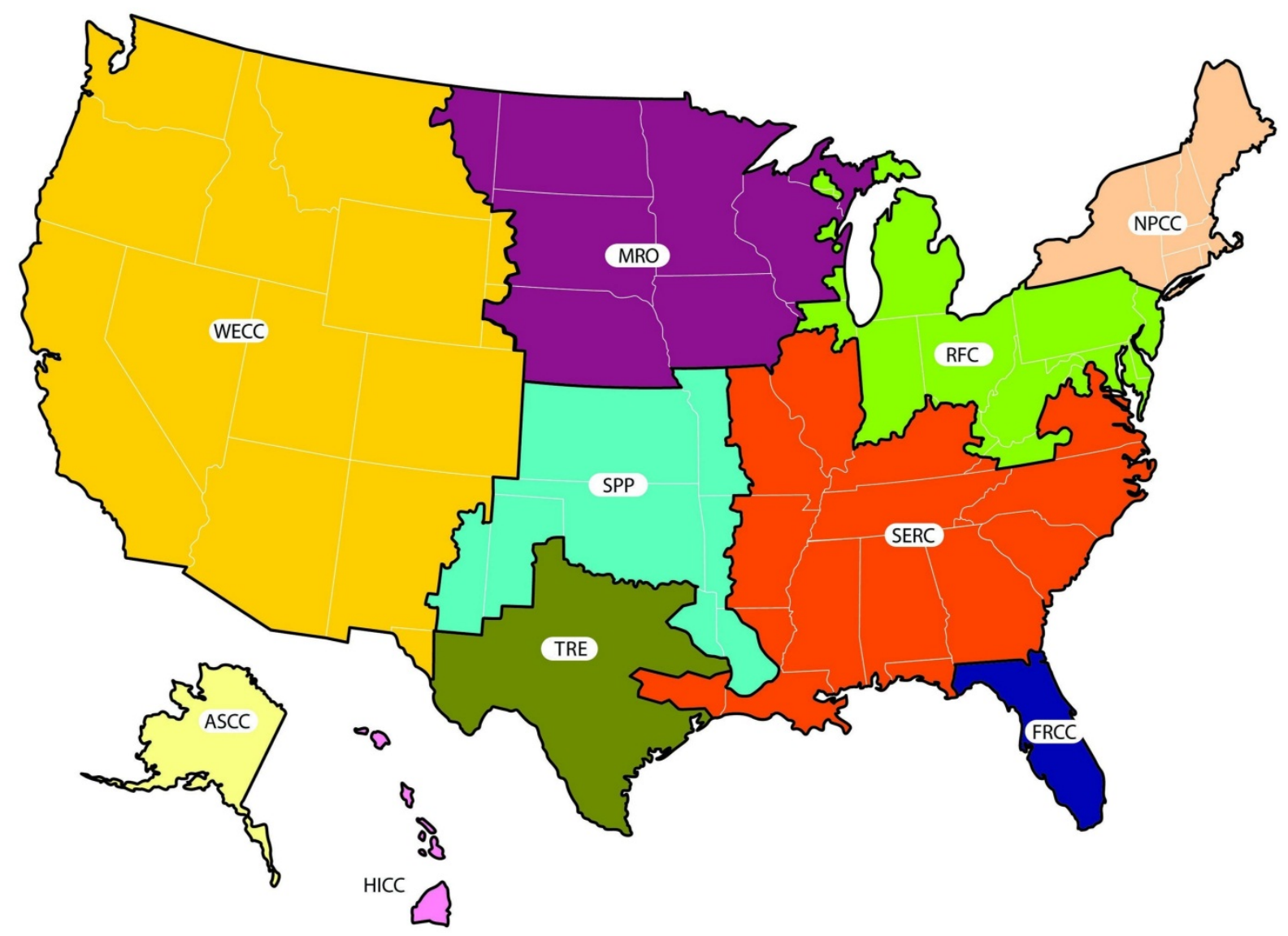

This Is a representational map; many of the boundaries shown on this map are approximate because they are based on companies, not on strictly geographical boundaries. USEPA eGRID2010 Version $1.0 \quad$ December 2010

FIGURE 1 NERC region representational map from eGRID 2010 (EPA, 2011a). 
TABLE 14 GHG and CAP emission factors (g/kWh), efficiencies, and combustion technology shares by NERC region

\begin{tabular}{|c|c|c|c|c|c|c|c|c|c|c|c|c|}
\hline & Fuel type (Share) & $\begin{array}{l}\text { Combustion } \\
\text { technology (Share) }\end{array}$ & Efficiency & $\mathrm{CO}_{2}$ & $\mathrm{CH}_{4}$ & $\mathrm{~N}_{2} \mathrm{O}$ & $\mathrm{NO}_{\mathrm{x}}$ & $\mathrm{SO}_{\mathrm{x}}$ & $\mathrm{PM}_{10}$ & $\mathrm{PM}_{2.5}$ & VOC & $\mathrm{CO}$ \\
\hline \multirow[t]{6}{*}{ ASCC } & NG (62.1\%) & CC (97.2\%) & $36.0 \%$ & 557.3 & 0.0111 & 0.0011 & 0.9152 & 0.0166 & 0.0012 & 0.0012 & 0.0024 & 0.0401 \\
\hline & & CT (2.8\%) & $23.5 \%$ & 854.9 & 0.0171 & 0.0017 & 2.0208 & 0.0272 & 0.0483 & 0.0483 & 0.0154 & 0.5995 \\
\hline & Oil (19.4\%) & BLR (14.9\%) & $17.1 \%$ & 1602.9 & 0.0676 & 0.0136 & 3.2793 & 7.3504 & 0.5714 & 0.4427 & 0.0491 & 0.3227 \\
\hline & & CT (67\%) & $36.7 \%$ & 731.9 & 0.0315 & 0.0063 & 1.5096 & 1.7450 & 0.2772 & 0.0666 & 0.0002 & 0.0156 \\
\hline & & ICE (32.1\%) & $36.9 \%$ & 731.9 & 0.0313 & 0.0063 & 10.9435 & 0.9276 & 0.3650 & 0.3476 & 0.3795 & 1.0710 \\
\hline & Renewable (23.0\%) & & & & & & & & & & & \\
\hline \multirow[t]{11}{*}{ FRCC } & Biomass (1.6\%) & BLR (100\%) & $18.5 \%$ & 0.0 & 0.6523 & 0.0869 & 7.1656 & 19.5981 & 3.4773 & 2.5525 & 0.1595 & 5.6289 \\
\hline & Coal (28.7\%) & BLR (100\%) & $38.1 \%$ & 866.1 & 0.0100 & 0.0143 & 1.7538 & 2.3667 & 0.5281 & 0.2543 & 0.0101 & 0.0885 \\
\hline & NG (54.6\%) & BLR (0.5\%) & $29.7 \%$ & 740.7 & 0.0201 & 0.0030 & 0.9373 & 1.8034 & 0.0403 & 0.0403 & 0.0292 & 0.4453 \\
\hline & & CC (94.2\%) & $49.0 \%$ & 432.6 & 0.0097 & 0.0012 & 0.2112 & 0.2524 & 0.0010 & 0.0010 & 0.0018 & 0.0248 \\
\hline & & СТ (5.1\%) & $32.6 \%$ & 651.3 & 0.0139 & 0.0016 & 0.4813 & 0.3056 & 0.0348 & 0.0348 & 0.0111 & 0.4324 \\
\hline & & $\operatorname{ICE}(0.2 \%)$ & $30.9 \%$ & 605.1 & 0.0137 & 0.0017 & 7.8771 & 0.0543 & 0.2819 & 0.2819 & 0.6633 & 2.2815 \\
\hline & Oil (7.2\%) & BLR (98.9\%) & $32.3 \%$ & 808.1 & 0.0301 & 0.0058 & 1.8445 & 4.7224 & 0.1825 & 0.1475 & 0.0259 & 0.1706 \\
\hline & & СТ (0.8\%) & $26.3 \%$ & 1026.5 & 0.0439 & 0.0088 & 1.9517 & 0.5748 & 0.3792 & 0.0910 & 0.0025 & 0.0204 \\
\hline & & ICE (0.3\%) & $32.8 \%$ & 834.0 & 0.0353 & 0.0071 & 12.3126 & 6.1956 & 0.0770 & 0.0530 & 0.0530 & 0.1410 \\
\hline & Nuclear (7.1\%) & & & & & & & & & & & \\
\hline & Renewable (0.8\%) & & & & & & & & & & & \\
\hline \multirow[t]{3}{*}{ HICC } & Biomass (3.9\%) & BLR (100\%) & $27.8 \%$ & 0.0 & 0.4319 & 0.0576 & 5.0604 & 13.0940 & 2.3436 & 1.6598 & 0.1057 & 3.7299 \\
\hline & Coal (17.6\%) & BLR (100\%) & $38.4 \%$ & 864.4 & 0.0140 & 0.0151 & 4.2348 & 14.1123 & 4.7987 & 1.6375 & 0.0108 & 0.0901 \\
\hline & Renewable (7.1\%) & & & & & & & & & & & \\
\hline \multirow[t]{8}{*}{ MRO } & Biomass (0.6\%) & BLR (100\%) & $21.1 \%$ & 0.0 & 0.5075 & 0.0703 & 4.8511 & 10.0371 & 2.2520 & 1.6394 & 0.1396 & 4.9273 \\
\hline & Coal (68.8\%) & BLR (100\%) & $32.5 \%$ & 1064.7 & 0.0120 & 0.0179 & 1.8142 & 3.6044 & 0.2247 & 0.0751 & 0.0168 & 0.1931 \\
\hline & NG (5.2\%) & BLR (2.3\%) & $28.0 \%$ & 749.5 & 0.0146 & 0.0015 & 2.5679 & 0.3650 & 0.0377 & 0.0377 & 0.0348 & 0.5308 \\
\hline & & CC (70.9\%) & $48.2 \%$ & 418.1 & 0.0082 & 0.0008 & 0.0636 & 0.0037 & 0.0022 & 0.0022 & 0.0024 & 0.0298 \\
\hline & & CT (24.5\%) & $30.2 \%$ & 693.1 & 0.0149 & 0.0017 & 0.5968 & 0.0188 & 0.0375 & 0.0375 & 0.0119 & 0.4658 \\
\hline & & ICE (2.4\%) & $29.9 \%$ & 78.3 & 0.0020 & 0.0003 & 6.3403 & 0.0198 & 0.5119 & 0.5119 & 1.2044 & 4.1427 \\
\hline & Oil (0.1\%) & CT (83\%) & $22.5 \%$ & 1208.2 & 0.0513 & 0.0103 & 2.2815 & 1.9150 & 0.4432 & 0.1064 & 0.0030 & 0.0238 \\
\hline & & ICE (17\%) & $31.1 \%$ & 867.1 & 0.0370 & 0.0074 & 12.9216 & 0.7968 & 0.1323 & 0.0389 & 0.0098 & 0.0349 \\
\hline
\end{tabular}


TABLE 14 (Cont.)

\begin{tabular}{|c|c|c|c|c|c|c|c|c|c|c|c|c|}
\hline & Fuel type (Share) & $\begin{array}{l}\text { Combustion } \\
\text { technology (Share) }\end{array}$ & Efficiency & $\mathrm{CO} 2$ & $\mathrm{CH} 4$ & $\mathrm{~N} 2 \mathrm{O}$ & NOx & SOx & PM10 & PM2.5 & VOC & $\mathrm{CO}$ \\
\hline & Nuclear (18.0\%) & & & & & & & & & & & \\
\hline & Renewable (7.3\%) & & & & & & & & & & & \\
\hline \multirow[t]{11}{*}{ NPCC } & Biomass (2.8\%) & BLR (100\%) & $22.1 \%$ & 0.0 & 0.5454 & 0.0727 & 4.6645 & 11.1070 & 2.6982 & 2.2025 & 0.1331 & 4.6982 \\
\hline & Coal (16.2\%) & BLR (100\%) & $35.8 \%$ & 932.0 & 0.0126 & 0.0160 & 0.8733 & 4.1888 & 0.1475 & 0.0974 & 0.0129 & 0.2563 \\
\hline & NG (29.8\%) & BLR (13.5\%) & $33.6 \%$ & 649.8 & 0.0149 & 0.0019 & 0.6403 & 0.4175 & 0.0312 & 0.0312 & 0.0259 & 0.3949 \\
\hline & & CC (83\%) & $50.5 \%$ & 406.1 & 0.0079 & 0.0008 & 0.0447 & 0.0321 & 0.0008 & 0.0008 & 0.0017 & 0.0283 \\
\hline & & CT (2.8\%) & $32.6 \%$ & 590.4 & 0.0125 & 0.0014 & 0.3462 & 0.0157 & 0.0419 & 0.0419 & 0.0153 & 0.5707 \\
\hline & & ICE $(0.7 \%)$ & $31.0 \%$ & 19.9 & 0.0006 & 0.0001 & 1.3221 & 0.0025 & 0.5199 & 0.5199 & 1.2233 & 4.2078 \\
\hline & Oil (4.9\%) & $\operatorname{BLR}(97.2 \%)$ & $33.2 \%$ & 753.4 & 0.0288 & 0.0055 & 0.7491 & 2.3168 & 0.0555 & 0.0542 & 0.0252 & 0.1658 \\
\hline & & CT (2.7\%) & $27.0 \%$ & 998.1 & 0.0429 & 0.0086 & 2.6288 & 0.2918 & 0.3706 & 0.1249 & 0.0052 & 0.0199 \\
\hline & & ICE $(0.2 \%)$ & $32.3 \%$ & 836.3 & 0.0358 & 0.0072 & 6.9454 & 0.8070 & 0.2010 & 0.0514 & 0.0060 & 0.0232 \\
\hline & Nuclear (33.3\%) & & & & & & & & & & & \\
\hline & Renewable (13.0\%) & & & & & & & & & & & \\
\hline \multirow[t]{11}{*}{ RFC } & Biomass (0.3\%) & BLR (100\%) & $22.3 \%$ & 0.0 & 0.5388 & 0.0718 & 6.1191 & 16.2785 & 2.8387 & 2.1352 & 0.1317 & 4.6495 \\
\hline & Coal (68.7\%) & BLR (100\%) & $35.6 \%$ & 939.6 & 0.0108 & 0.0159 & 1.4753 & 5.6119 & 0.2412 & 0.1566 & 0.0121 & 0.1080 \\
\hline & NG (5.0\%) & BLR (2.5\%) & $23.7 \%$ & 840.8 & 0.0138 & 0.0015 & 1.3211 & 0.5961 & 0.0568 & 0.0568 & 0.0385 & 0.6235 \\
\hline & & CC (79.9\%) & $48.6 \%$ & 417.2 & 0.0082 & 0.0008 & 0.0699 & 0.0031 & 0.0017 & 0.0017 & 0.0022 & 0.0296 \\
\hline & & CT (15.4\%) & $31.7 \%$ & 610.9 & 0.0122 & 0.0013 & 0.3884 & 0.0113 & 0.0412 & 0.0412 & 0.0146 & 0.5515 \\
\hline & & ICE (2.2\%) & $28.9 \%$ & 32.5 & 0.0007 & 0.0001 & 2.7549 & 0.0066 & 0.5566 & 0.5566 & 1.3096 & 4.5045 \\
\hline & Oil (0.04\%) & BLR (45.9\%) & $26.6 \%$ & 1044.3 & 0.0435 & 0.0087 & 1.5655 & 5.0382 & 0.2689 & 0.2045 & 0.0322 & 0.2120 \\
\hline & & CT (42.4\%) & $23.7 \%$ & 1152.2 & 0.0487 & 0.0098 & 1.6385 & 0.9399 & 0.4223 & 0.1303 & 0.0050 & 0.0226 \\
\hline & & ICE (11.7\%) & $31.9 \%$ & 848.0 & 0.0362 & 0.0073 & 8.0963 & 1.3231 & 0.1254 & 0.0359 & 0.0092 & 0.0301 \\
\hline & Nuclear (25.2\%) & & & & & & & & & & & \\
\hline & Renewable (0.8\%) & & & & & & & & & & & \\
\hline \multirow[t]{4}{*}{ SERC } & Biomass $(0.2 \%)$ & BLR (100\%) & $16.4 \%$ & 0.0 & 0.5034 & 0.0795 & 5.2167 & 13.3054 & 2.4654 & 1.7274 & 0.1145 & 3.6799 \\
\hline & Coal (62.2\%) & BLR (100\%) & $35.4 \%$ & 941.6 & 0.0109 & 0.0159 & 1.2030 & 4.0612 & 0.1777 & 0.1394 & 0.0126 & 0.1107 \\
\hline & NG (9.2\%) & BLR (20.3\%) & $30.7 \%$ & 666.3 & 0.0143 & 0.0016 & 1.3967 & 0.2118 & 0.0415 & 0.0415 & 0.0303 & 0.4653 \\
\hline & & CC (66.5\%) & $49.8 \%$ & 411.5 & 0.0082 & 0.0009 & 0.0728 & 0.0308 & 0.0008 & 0.0008 & 0.0017 & 0.0290 \\
\hline
\end{tabular}


TABLE 14 (Cont.)

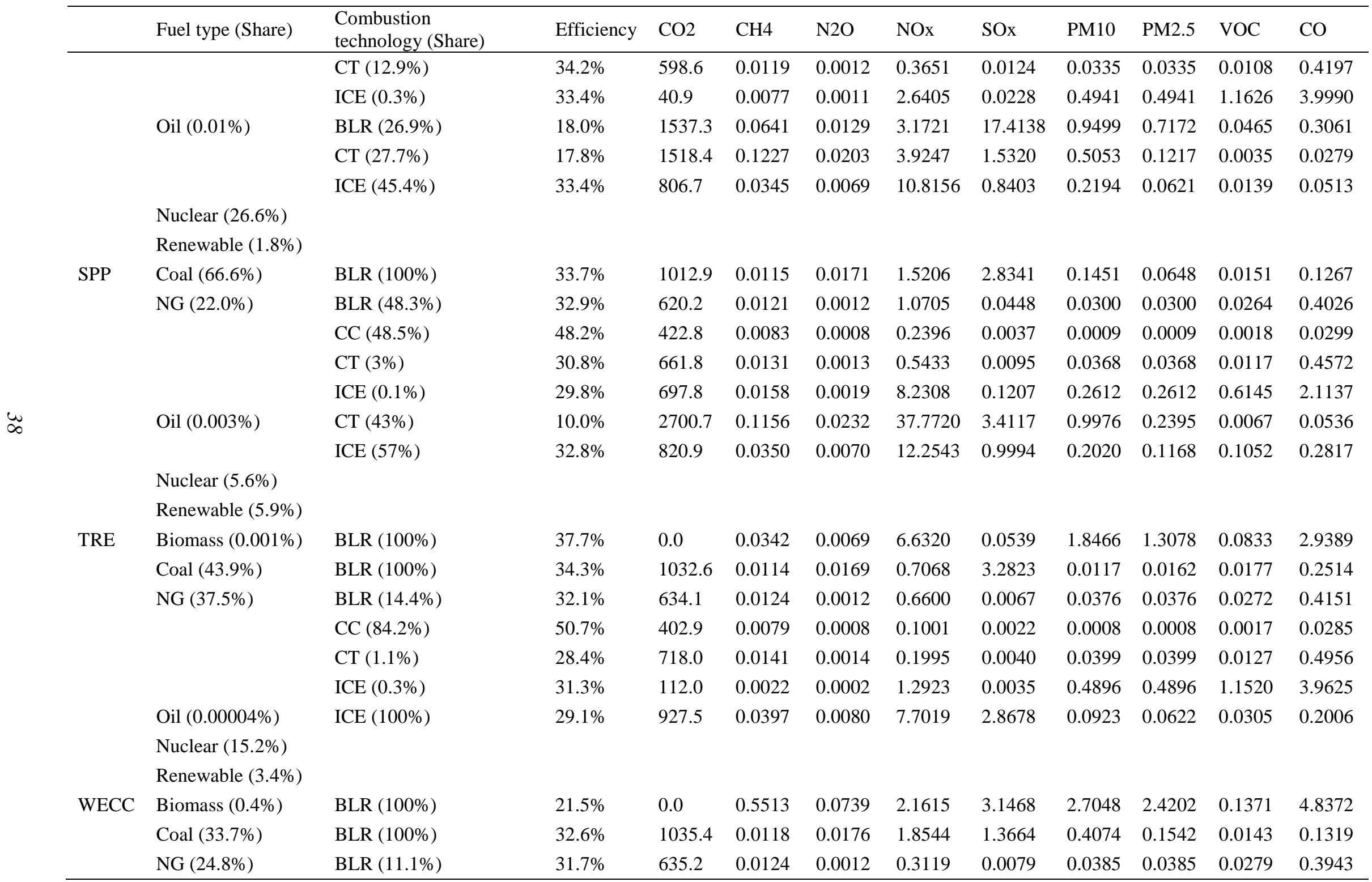


TABLE 14 (Cont.)

\begin{tabular}{|c|c|c|c|c|c|c|c|c|c|c|c|}
\hline Fuel type (Share) & $\begin{array}{l}\text { Combustion } \\
\text { technology (Share) }\end{array}$ & Efficiency & $\mathrm{CO} 2$ & $\mathrm{CH} 4$ & $\mathrm{~N} 2 \mathrm{O}$ & NOx & SOx & PM10 & PM2.5 & VOC & $\mathrm{CO}$ \\
\hline & CC (84\%) & $50.4 \%$ & 404.2 & 0.0079 & 0.0008 & 0.0722 & 0.0023 & 0.0010 & 0.0010 & 0.0018 & 0.0284 \\
\hline & CT (4\%) & $33.2 \%$ & 555.1 & 0.0109 & 0.0011 & 0.3491 & 0.0065 & 0.0436 & 0.0436 & 0.0165 & 0.6103 \\
\hline & $\operatorname{ICE}(0.9 \%)$ & $27.2 \%$ & 460.3 & 0.0093 & 0.0009 & 3.7693 & 0.0186 & 0.4558 & 0.4558 & 1.0725 & 3.6889 \\
\hline \multirow[t]{2}{*}{ Oil (0.01\%) } & CT (46.2\%) & $26.1 \%$ & 1015.7 & 0.0443 & 0.0089 & 1.6736 & 0.3139 & 0.3823 & 0.0918 & 0.0026 & 0.0205 \\
\hline & ICE (53.8\%) & $34.1 \%$ & 792.2 & 0.0339 & 0.0068 & 7.1531 & 1.0254 & 0.2876 & 0.0715 & 0.0053 & 0.0253 \\
\hline Nuclear (10.8\%) & & & & & & & & & & & \\
\hline Renewable (30.2\%) & & & & & & & & & & & \\
\hline
\end{tabular}

Note: Totals of shares may not sum, owing to independent rounding. 


\subsection{GHG AND CAP EMISSION FACTORS AND EFFICIENCIES BY FUEL TYPE AND GENERATION TECHNOLOGY IN EACH STATE}

GHG and CAP emission factors and efficiencies for EGUs in the 50 states and the Washington, D.C. area (DC) are summarized in Table 15. Significant variations in GHG and CAP emission factors among states are found, mostly because of differences among states in the efficiencies of EGUs and the fuel quality. 
TABLE 15 GHG and CAP emission factors and efficiencies in each state

\begin{tabular}{|c|c|c|c|c|c|c|c|c|c|c|c|}
\hline & Technology Share & Efficiency & $\mathrm{CO}_{2}$ & $\mathrm{CH}_{4}$ & $\mathrm{~N}_{2} \mathrm{O}$ & $\mathrm{NO}_{\mathrm{x}}$ & $\mathrm{SO}_{\mathrm{x}}$ & $\mathrm{PM}_{10}$ & $\mathrm{PM}_{2.5}$ & VOC & $\mathrm{CO}$ \\
\hline \multicolumn{12}{|l|}{ AK } \\
\hline NG & & $35.5 \%$ & 565.6 & 0.0113 & 0.0011 & 0.9460 & 0.0169 & 0.0025 & 0.0025 & 0.0027 & 0.0557 \\
\hline $\mathrm{CC}$ & $97.21 \%$ & $36.0 \%$ & 557.3 & 0.0111 & 0.0011 & 0.9152 & 0.0166 & 0.0012 & 0.0012 & 0.0024 & 0.0401 \\
\hline $\mathrm{CT}$ & $2.79 \%$ & $23.5 \%$ & 854.9 & 0.0171 & 0.0017 & 2.0208 & 0.0272 & 0.0483 & 0.0483 & 0.0154 & 0.5995 \\
\hline Oil & & $36.4 \%$ & 739.2 & 0.0317 & 0.0064 & 4.5554 & 1.5293 & 0.3078 & 0.1600 & 0.1225 & 0.3572 \\
\hline Boiler & $0.84 \%$ & $17.1 \%$ & 1602.9 & 0.0676 & 0.0136 & 3.2793 & 7.3504 & 0.5714 & 0.4427 & 0.0491 & 0.3227 \\
\hline CT & $67.03 \%$ & $36.7 \%$ & 731.9 & 0.0315 & 0.0063 & 1.5096 & 1.7450 & 0.2772 & 0.0666 & 0.0002 & 0.0156 \\
\hline ICE & $32.13 \%$ & $36.9 \%$ & 731.9 & 0.0313 & 0.0063 & 10.9435 & 0.9276 & 0.3650 & 0.3476 & 0.3795 & 1.0710 \\
\hline \multicolumn{12}{|c|}{ Renewable } \\
\hline WAT & $100.00 \%$ & & & & & & & & & & \\
\hline \multicolumn{12}{|l|}{ AL } \\
\hline Coal & & $34.7 \%$ & 948.4 & 0.0110 & 0.0158 & 1.3231 & 4.8614 & 0.1444 & 0.1322 & 0.0126 & 0.1046 \\
\hline Boiler & $100.00 \%$ & $34.7 \%$ & 948.4 & 0.0110 & 0.0158 & 1.3231 & 4.8614 & 0.1444 & 0.1322 & 0.0126 & 0.1046 \\
\hline NG & & $49.6 \%$ & 411.4 & 0.0081 & 0.0008 & 0.0681 & 0.0021 & 0.0023 & 0.0023 & 0.0021 & 0.0461 \\
\hline $\mathrm{CC}$ & $95.40 \%$ & $50.7 \%$ & 402.4 & 0.0079 & 0.0008 & 0.0602 & 0.0020 & 0.0008 & 0.0008 & 0.0017 & 0.0285 \\
\hline $\mathrm{CT}$ & $4.60 \%$ & $34.3 \%$ & 595.3 & 0.0117 & 0.0012 & 0.2274 & 0.0045 & 0.0330 & 0.0330 & 0.0105 & 0.4102 \\
\hline \multicolumn{12}{|l|}{ Nuclear } \\
\hline \multicolumn{12}{|c|}{ Renewable } \\
\hline WAT & $100.00 \%$ & & & & & & & & & & \\
\hline \multicolumn{12}{|l|}{$\mathbf{A R}$} \\
\hline Biomass & & $8.4 \%$ & 333.1 & 0.4091 & 0.1096 & 3.6815 & 8.9086 & 1.3370 & 0.4159 & 0.0615 & 0.5743 \\
\hline Boiler & $100.00 \%$ & $8.4 \%$ & 333.1 & 0.4091 & 0.1096 & 3.6815 & 8.9086 & 1.3370 & 0.4159 & 0.0615 & 0.5743 \\
\hline Coal & & $33.5 \%$ & 1018.6 & 0.0116 & 0.0173 & 1.2935 & 2.5368 & 0.0657 & 0.0355 & 0.0147 & 0.1225 \\
\hline Boiler & $100.00 \%$ & $33.5 \%$ & 1018.6 & 0.0116 & 0.0173 & 1.2935 & 2.5368 & 0.0657 & 0.0355 & 0.0147 & 0.1225 \\
\hline
\end{tabular}


TABLE 15 (Cont.)

\begin{tabular}{|c|c|c|c|c|c|c|c|c|c|c|c|}
\hline & Technology Share & Efficiency & $\mathrm{CO}_{2}$ & $\mathrm{CH}_{4}$ & $\mathrm{~N}_{2} \mathrm{O}$ & $\mathrm{NO}_{\mathrm{x}}$ & $\mathrm{SO}_{\mathrm{x}}$ & $\mathrm{PM}_{10}$ & $\mathrm{PM}_{2.5}$ & VOC & $\mathrm{CO}$ \\
\hline \multicolumn{12}{|l|}{ AR (cont.) } \\
\hline NG & & $47.9 \%$ & 424.5 & 0.0083 & 0.0008 & 0.1709 & 0.0593 & 0.0054 & 0.0054 & 0.0088 & 0.0717 \\
\hline Boiler & $3.63 \%$ & $28.1 \%$ & 761.6 & 0.0142 & 0.0014 & 1.5766 & 1.5345 & 0.0426 & 0.0426 & 0.0309 & 0.4713 \\
\hline CC & $93.57 \%$ & $49.5 \%$ & 412.2 & 0.0081 & 0.0008 & 0.0776 & 0.0037 & 0.0008 & 0.0008 & 0.0017 & 0.0287 \\
\hline CT & $2.30 \%$ & $42.3 \%$ & 479.3 & 0.0095 & 0.0009 & 0.4256 & 0.0032 & 0.0268 & 0.0268 & 0.0085 & 0.3332 \\
\hline ICE & $0.49 \%$ & $30.8 \%$ & 22.0 & 0.0004 & 0.0000 & 6.3742 & 0.0006 & 0.5052 & 0.5052 & 1.1888 & 4.0891 \\
\hline \multicolumn{12}{|l|}{ Nuclear } \\
\hline Oil & & $35.8 \%$ & 753.1 & 0.0322 & 0.0065 & 11.2614 & 0.9493 & 1.4319 & 1.4319 & 1.6629 & 4.3882 \\
\hline ICE & $100.00 \%$ & $35.8 \%$ & 753.1 & 0.0322 & 0.0065 & 11.2614 & 0.9493 & 1.4319 & 1.4319 & 1.6629 & 4.3882 \\
\hline \multicolumn{12}{|c|}{ Renewable } \\
\hline WAT & $100.00 \%$ & & & & & & & & & & \\
\hline \multicolumn{12}{|l|}{$\mathbf{A Z}$} \\
\hline Coal & & $30.7 \%$ & 1094.7 & 0.0125 & 0.0185 & 1.7874 & 1.2365 & 0.1095 & 0.0802 & 0.0149 & 0.1246 \\
\hline Boiler & $100.00 \%$ & $30.7 \%$ & 1094.7 & 0.0125 & 0.0185 & 1.7874 & 1.2365 & 0.1095 & 0.0802 & 0.0149 & 0.1246 \\
\hline NG & & $51.4 \%$ & 397.0 & 0.0078 & 0.0008 & 0.0734 & 0.0021 & 0.0018 & 0.0018 & 0.0021 & 0.0384 \\
\hline Boiler & $1.32 \%$ & $31.2 \%$ & 653.9 & 0.0128 & 0.0013 & 1.3514 & 0.0042 & 0.0384 & 0.0384 & 0.0278 & 0.4248 \\
\hline CC & $97.40 \%$ & $52.3 \%$ & 389.9 & 0.0076 & 0.0008 & 0.0487 & 0.0020 & 0.0008 & 0.0008 & 0.0016 & 0.0276 \\
\hline $\mathrm{CT}$ & $1.29 \%$ & $30.6 \%$ & 666.5 & 0.0132 & 0.0013 & 0.6340 & 0.0090 & 0.0370 & 0.0370 & 0.0118 & 0.4598 \\
\hline \multicolumn{12}{|l|}{ Nuclear } \\
\hline Oil & & $17.1 \%$ & 1562.3 & 0.0662 & 0.0132 & 14.3586 & 1.9171 & 0.3346 & 0.1198 & 0.0317 & 0.2111 \\
\hline $\mathrm{CT}$ & $47.20 \%$ & $19.3 \%$ & 1396.4 & 0.0598 & 0.0120 & 2.6550 & 1.7512 & 0.5158 & 0.1238 & 0.0034 & 0.0277 \\
\hline ICE & $52.80 \%$ & $15.6 \%$ & 1710.6 & 0.0719 & 0.0143 & 24.8222 & 2.0655 & 0.1725 & 0.1163 & 0.0570 & 0.3751 \\
\hline \multicolumn{12}{|c|}{ Renewable } \\
\hline SUN & $0.10 \%$ & & & & & & & & & & \\
\hline WAT & $99.90 \%$ & & & & & & & & & & \\
\hline
\end{tabular}


TABLE 15 (Cont.)

\begin{tabular}{|c|c|c|c|c|c|c|c|c|c|c|c|}
\hline & Technology Share & Efficiency & $\mathrm{CO}_{2}$ & $\mathrm{CH}_{4}$ & $\mathrm{~N}_{2} \mathrm{O}$ & $\mathrm{NO}_{\mathrm{x}}$ & $\mathrm{SO}_{\mathrm{x}}$ & $\mathrm{PM}_{10}$ & $\mathrm{PM}_{2.5}$ & VOC & $\mathrm{CO}$ \\
\hline \multicolumn{12}{|l|}{ CA } \\
\hline Biomass & & $21.7 \%$ & 157.4 & 0.5470 & 0.0733 & 1.8362 & 2.0516 & 2.6666 & 2.4212 & 0.1362 & 4.8060 \\
\hline Boiler & $100.00 \%$ & $21.7 \%$ & 157.4 & 0.5470 & 0.0733 & 1.8362 & 2.0516 & 2.6666 & 2.4212 & 0.1362 & 4.8060 \\
\hline Coal & & $31.8 \%$ & 1162.3 & 0.0120 & 0.0180 & 3.8007 & 11.3622 & 6.4524 & 3.6754 & 0.0127 & 0.1086 \\
\hline Boiler & $100.00 \%$ & $31.8 \%$ & 1162.3 & 0.0120 & 0.0180 & 3.8007 & 11.3622 & 6.4524 & 3.6754 & 0.0127 & 0.1086 \\
\hline NG & & $43.7 \%$ & 453.3 & 0.0089 & 0.0009 & 0.0787 & 0.0037 & 0.0186 & 0.0186 & 0.0254 & 0.1964 \\
\hline Boiler & $21.72 \%$ & $31.5 \%$ & 638.0 & 0.0124 & 0.0012 & 0.1348 & 0.0085 & 0.0388 & 0.0388 & 0.0281 & 0.3914 \\
\hline CC & $73.80 \%$ & $51.1 \%$ & 399.0 & 0.0078 & 0.0008 & 0.0301 & 0.0020 & 0.0012 & 0.0012 & 0.0019 & 0.0279 \\
\hline $\mathrm{CT}$ & $3.49 \%$ & $33.2 \%$ & 444.8 & 0.0088 & 0.0009 & 0.3000 & 0.0060 & 0.0600 & 0.0600 & 0.0263 & 0.9311 \\
\hline ICE & $0.99 \%$ & $20.1 \%$ & 475.7 & 0.0095 & 0.0010 & 1.6870 & 0.0157 & 0.7280 & 0.7280 & 1.7130 & 5.8920 \\
\hline \multicolumn{12}{|l|}{ Nuclear } \\
\hline Oil & & $30.7 \%$ & 869.8 & 0.0377 & 0.0076 & 4.3230 & 0.5961 & 0.3251 & 0.0780 & 0.0022 & 0.0175 \\
\hline $\mathrm{CT}$ & $43.65 \%$ & $26.7 \%$ & 988.5 & 0.0433 & 0.0087 & 1.5642 & 0.0655 & 0.3738 & 0.0897 & 0.0025 & 0.0201 \\
\hline ICE & $56.35 \%$ & $34.7 \%$ & 777.9 & 0.0333 & 0.0067 & 6.4602 & 1.0071 & 0.2873 & 0.0690 & 0.0019 & 0.0154 \\
\hline \multicolumn{12}{|c|}{ Renewable } \\
\hline SUN & $0.01 \%$ & & & & & & & & & & \\
\hline GEO & $28.00 \%$ & & & & & & & & & & \\
\hline WAT & $59.55 \%$ & & & & & & & & & & \\
\hline WH & $0.40 \%$ & & & & & & & & & & \\
\hline WND & $12.04 \%$ & & & & & & & & & & \\
\hline \multicolumn{12}{|l|}{ CO } \\
\hline Coal & & $32.7 \%$ & 1030.3 & 0.0117 & 0.0175 & 1.6324 & 1.6601 & 0.1034 & 0.0583 & 0.0141 & 0.1989 \\
\hline Boiler & $100.00 \%$ & $32.7 \%$ & 1030.3 & 0.0117 & 0.0175 & 1.6324 & 1.6601 & 0.1034 & 0.0583 & 0.0141 & 0.1989 \\
\hline NG & & $44.0 \%$ & 464.9 & 0.0091 & 0.0009 & 0.1778 & 0.0033 & 0.0082 & 0.0082 & 0.0075 & 0.1108 \\
\hline Boiler & $0.24 \%$ & $27.5 \%$ & 738.6 & 0.0155 & 0.0017 & 1.8573 & 0.0679 & 0.0435 & 0.0435 & 0.0315 & 0.4813 \\
\hline CC & $81.88 \%$ & $47.1 \%$ & 433.5 & 0.0085 & 0.0009 & 0.0845 & 0.0023 & 0.0009 & 0.0009 & 0.0018 & 0.0307 \\
\hline CT & $16.98 \%$ & $34.0 \%$ & 610.0 & 0.0118 & 0.0012 & 0.3068 & 0.0067 & 0.0334 & 0.0334 & 0.0106 & 0.4147 \\
\hline ICE & $0.89 \%$ & $39.8 \%$ & 504.2 & 0.0101 & 0.0010 & 5.8419 & 0.0146 & 0.1953 & 0.1953 & 0.4594 & 1.5803 \\
\hline
\end{tabular}




\begin{tabular}{|c|c|c|c|c|c|c|c|c|c|c|c|}
\hline \multicolumn{12}{|c|}{ TABLE 15 (Cont.) } \\
\hline & Technology Share & Efficiency & $\mathrm{CO}_{2}$ & $\mathrm{CH}_{4}$ & $\mathrm{~N}_{2} \mathrm{O}$ & $\mathrm{NO}_{\mathrm{x}}$ & $\mathrm{SO}_{\mathrm{x}}$ & $\mathrm{PM}_{10}$ & $\mathrm{PM}_{2.5}$ & VOC & $\mathrm{CO}$ \\
\hline \multicolumn{12}{|l|}{ CO (cont.) } \\
\hline Oil & & $25.2 \%$ & 1069.5 & 0.0458 & 0.0092 & 4.2675 & 1.3491 & 0.4059 & 0.1077 & 0.0183 & 0.0624 \\
\hline $\mathrm{CT}$ & $79.93 \%$ & $24.0 \%$ & 1123.9 & 0.0481 & 0.0097 & 2.1368 & 1.4085 & 0.4151 & 0.0997 & 0.0028 & 0.0223 \\
\hline ICE & $20.07 \%$ & $31.6 \%$ & 853.0 & 0.0365 & 0.0073 & 12.7542 & 1.1125 & 0.3692 & 0.1397 & 0.0800 & 0.2221 \\
\hline \multicolumn{12}{|c|}{ Renewable } \\
\hline SUN & $0.08 \%$ & & & & & & & & & & \\
\hline WAT & $53.91 \%$ & & & & & & & & & & \\
\hline WH & $1.42 \%$ & & & & & & & & & & \\
\hline WND & $44.59 \%$ & & & & & & & & & & \\
\hline \multicolumn{12}{|l|}{ CT } \\
\hline Biomass & & $21.9 \%$ & 1279.5 & 0.5522 & 0.0736 & 6.2365 & 17.2804 & 2.9823 & 2.1121 & 0.1345 & 4.7464 \\
\hline Boiler & $100.00 \%$ & $21.9 \%$ & 1279.5 & 0.5522 & 0.0736 & 6.2365 & 17.2804 & 2.9823 & 2.1121 & 0.1345 & 4.7464 \\
\hline Coal & & $31.8 \%$ & 1033.4 & 0.0423 & 0.0206 & 1.0040 & 2.2255 & 0.3269 & 0.1144 & 0.0151 & 0.1258 \\
\hline Boiler & $100.00 \%$ & $31.8 \%$ & 1033.4 & 0.0423 & 0.0206 & 1.0040 & 2.2255 & 0.3269 & 0.1144 & 0.0151 & 0.1258 \\
\hline NG & & $50.9 \%$ & 399.5 & 0.0078 & 0.0008 & 0.0387 & 0.0020 & 0.0021 & 0.0021 & 0.0021 & 0.0441 \\
\hline Boiler & $0.15 \%$ & $33.1 \%$ & 0.0 & 0.0000 & 0.0000 & 1.1815 & 0.0000 & 0.0751 & 0.0751 & 0.0544 & 0.8305 \\
\hline CC & $96.66 \%$ & $51.6 \%$ & 395.4 & 0.0077 & 0.0008 & 0.0349 & 0.0020 & 0.0008 & 0.0008 & 0.0017 & 0.0280 \\
\hline $\mathrm{CT}$ & $3.19 \%$ & $35.6 \%$ & 543.2 & 0.0106 & 0.0011 & 0.0985 & 0.0029 & 0.0369 & 0.0369 & 0.0132 & 0.4955 \\
\hline \multicolumn{12}{|l|}{ Nuclear } \\
\hline Oil & & $28.7 \%$ & 898.2 & 0.0373 & 0.0073 & 1.0111 & 1.2739 & 0.0642 & 0.0612 & 0.0289 & 0.1892 \\
\hline Boiler & $98.46 \%$ & $28.7 \%$ & 895.3 & 0.0372 & 0.0073 & 1.0019 & 1.2892 & 0.0586 & 0.0583 & 0.0292 & 0.1918 \\
\hline CT & $1.48 \%$ & $24.2 \%$ & 1093.5 & 0.0477 & 0.0096 & 1.3993 & 0.2991 & 0.4266 & 0.2529 & 0.0128 & 0.0225 \\
\hline ICE & $0.06 \%$ & $33.4 \%$ & 807.4 & 0.0346 & 0.0069 & 6.7054 & 0.2031 & 0.2983 & 0.0716 & 0.0020 & 0.0160 \\
\hline \multicolumn{12}{|c|}{ Renewable } \\
\hline WAT & $100.00 \%$ & & & & & & & & & & \\
\hline
\end{tabular}


TABLE 15 (Cont.)

\begin{tabular}{|c|c|c|c|c|c|c|c|c|c|c|c|}
\hline & Technology Share & Efficiency & $\mathrm{CO}_{2}$ & $\mathrm{CH}_{4}$ & $\mathrm{~N}_{2} \mathrm{O}$ & $\mathrm{NO}_{\mathrm{x}}$ & $\mathrm{SO}_{\mathrm{x}}$ & $\mathrm{PM}_{10}$ & $\mathrm{PM}_{2.5}$ & VOC & $\mathrm{CO}$ \\
\hline \multicolumn{12}{|l|}{ DC } \\
\hline Oil & & $21.3 \%$ & 1261.8 & 0.0542 & 0.0109 & 1.9254 & 4.5107 & 0.2147 & 0.0920 & 0.0317 & 0.2094 \\
\hline Boiler & $79.14 \%$ & $22.8 \%$ & 1179.3 & 0.0508 & 0.0102 & 1.7915 & 4.8160 & 0.1179 & 0.0795 & 0.0390 & 0.2564 \\
\hline CT & $20.86 \%$ & $17.1 \%$ & 1574.6 & 0.0674 & 0.0135 & 2.4336 & 3.3525 & 0.5816 & 0.1396 & 0.0039 & 0.0313 \\
\hline \multicolumn{12}{|l|}{ DE } \\
\hline Coal & & $33.3 \%$ & 989.1 & 0.0122 & 0.0166 & 1.5597 & 5.2623 & 0.7987 & 0.3835 & 0.0125 & 0.1039 \\
\hline Boiler & $100.00 \%$ & $33.3 \%$ & 989.1 & 0.0122 & 0.0166 & 1.5597 & 5.2623 & 0.7987 & 0.3835 & 0.0125 & 0.1039 \\
\hline NG & & $46.4 \%$ & 420.3 & 0.0083 & 0.0008 & 0.1937 & 0.0080 & 0.0083 & 0.0083 & 0.0153 & 0.0973 \\
\hline Boiler & $1.84 \%$ & $34.6 \%$ & 0.0 & 0.0000 & 0.0000 & 1.1303 & 0.0000 & 0.0761 & 0.0761 & 0.0551 & 0.8409 \\
\hline CC & $94.25 \%$ & $47.3 \%$ & 429.2 & 0.0085 & 0.0008 & 0.1675 & 0.0081 & 0.0009 & 0.0009 & 0.0018 & 0.0305 \\
\hline CT & $2.87 \%$ & $37.4 \%$ & 550.0 & 0.0107 & 0.0011 & 0.0907 & 0.0100 & 0.0303 & 0.0303 & 0.0096 & 0.3762 \\
\hline ICE & $1.03 \%$ & $32.7 \%$ & 0.0 & 0.0000 & 0.0000 & 1.1954 & 0.0000 & 0.5076 & 0.5076 & 1.1944 & 4.1084 \\
\hline Oil & & $31.3 \%$ & 823.7 & 0.0369 & 0.0074 & 1.6615 & 4.3285 & 0.2785 & 0.2037 & 0.0248 & 0.1634 \\
\hline Boiler & $95.97 \%$ & $32.6 \%$ & 786.5 & 0.0354 & 0.0071 & 1.6203 & 4.5014 & 0.2637 & 0.2059 & 0.0257 & 0.1689 \\
\hline $\mathrm{CT}$ & $4.03 \%$ & $15.8 \%$ & 1709.1 & 0.0732 & 0.0147 & 2.6416 & 0.2127 & 0.6313 & 0.1515 & 0.0042 & 0.0339 \\
\hline \multicolumn{12}{|l|}{ FL } \\
\hline Biomass & & $18.2 \%$ & 1459.2 & 0.6613 & 0.0881 & 7.2660 & 19.8987 & 3.5280 & 2.5867 & 0.1617 & 5.7078 \\
\hline Boiler & $100.00 \%$ & $18.2 \%$ & 1459.2 & 0.6613 & 0.0881 & 7.2660 & 19.8987 & 3.5280 & 2.5867 & 0.1617 & 5.7078 \\
\hline Coal & & $33.8 \%$ & 964.5 & 0.0112 & 0.0157 & 1.5870 & 2.0949 & 0.3287 & 0.1959 & 0.0112 & 0.0995 \\
\hline Boiler & $100.00 \%$ & $33.8 \%$ & 964.5 & 0.0112 & 0.0157 & 1.5870 & 2.0949 & 0.3287 & 0.1959 & 0.0112 & 0.0995 \\
\hline NG & & $47.6 \%$ & 444.7 & 0.0100 & 0.0012 & 0.2353 & 0.2626 & 0.0031 & 0.0031 & 0.0028 & 0.0495 \\
\hline Boiler & $0.57 \%$ & $29.8 \%$ & 688.3 & 0.0186 & 0.0028 & 1.3251 & 1.6759 & 0.0435 & 0.0435 & 0.0315 & 0.4809 \\
\hline CC & $94.09 \%$ & $49.0 \%$ & 432.6 & 0.0097 & 0.0012 & 0.2112 & 0.2524 & 0.0010 & 0.0010 & 0.0018 & 0.0248 \\
\hline CT & $5.16 \%$ & $32.6 \%$ & 650.1 & 0.0139 & 0.0016 & 0.4900 & 0.3024 & 0.0348 & 0.0348 & 0.0111 & 0.4318 \\
\hline ICE & $0.19 \%$ & $36.0 \%$ & 158.8 & 0.0036 & 0.0004 & 2.0674 & 0.0142 & 0.0740 & 0.0740 & 0.1741 & 0.5988 \\
\hline
\end{tabular}


TABLE 15 (Cont.)

\begin{tabular}{|c|c|c|c|c|c|c|c|c|c|c|c|}
\hline & Technology Share & Efficiency & $\mathrm{CO}_{2}$ & $\mathrm{CH}_{4}$ & $\mathrm{~N}_{2} \mathrm{O}$ & $\mathrm{NO}_{\mathrm{x}}$ & $\mathrm{SO}_{\mathrm{x}}$ & $\mathrm{PM}_{10}$ & $\mathrm{PM}_{2.5}$ & VOC & $\mathrm{CO}$ \\
\hline \multicolumn{12}{|l|}{ FL (cont.) } \\
\hline \multicolumn{12}{|l|}{ Nuclear } \\
\hline Oil & & $32.3 \%$ & 810.0 & 0.0303 & 0.0058 & 1.8766 & 4.6921 & 0.1838 & 0.1468 & 0.0258 & 0.1693 \\
\hline Boiler & $98.86 \%$ & $32.3 \%$ & 808.1 & 0.0301 & 0.0058 & 1.8445 & 4.7224 & 0.1825 & 0.1475 & 0.0259 & 0.1706 \\
\hline CT & $0.84 \%$ & $26.3 \%$ & 1026.5 & 0.0439 & 0.0088 & 1.9517 & 0.5748 & 0.3792 & 0.0910 & 0.0025 & 0.0204 \\
\hline ICE & $0.30 \%$ & $32.8 \%$ & 834.0 & 0.0353 & 0.0071 & 12.3126 & 6.1956 & 0.0770 & 0.0530 & 0.0530 & 0.1410 \\
\hline \multicolumn{12}{|c|}{ Renewable } \\
\hline WAT & $10.85 \%$ & & & & & & & & & & \\
\hline WH & $89.15 \%$ & & & & & & & & & & \\
\hline \multicolumn{12}{|l|}{ GA } \\
\hline Coal & & $35.6 \%$ & 942.0 & 0.0107 & 0.0160 & 1.0700 & 6.3986 & 0.2155 & 0.1850 & 0.0123 & 0.1024 \\
\hline Boiler & $100.00 \%$ & $35.6 \%$ & 942.0 & 0.0107 & 0.0160 & 1.0700 & 6.3986 & 0.2155 & 0.1850 & 0.0123 & 0.1024 \\
\hline NG & & $48.0 \%$ & 425.2 & 0.0083 & 0.0008 & 0.0768 & 0.0023 & 0.0048 & 0.0048 & 0.0029 & 0.0755 \\
\hline Boiler & $1.06 \%$ & $35.3 \%$ & 525.8 & 0.0103 & 0.0010 & 0.6295 & 0.0027 & 0.0375 & 0.0375 & 0.0271 & 0.4146 \\
\hline $\mathrm{CC}$ & $88.40 \%$ & $51.2 \%$ & 398.8 & 0.0078 & 0.0008 & 0.0434 & 0.0020 & 0.0008 & 0.0008 & 0.0017 & 0.0282 \\
\hline $\mathrm{CT}$ & $10.54 \%$ & $32.1 \%$ & 636.9 & 0.0125 & 0.0012 & 0.3013 & 0.0042 & 0.0353 & 0.0353 & 0.0112 & 0.4382 \\
\hline \multicolumn{12}{|l|}{ Nuclear } \\
\hline Oil & & $18.4 \%$ & 1492.2 & 0.0628 & 0.0126 & 4.7588 & 11.8946 & 0.7979 & 0.5195 & 0.0332 & 0.2198 \\
\hline Boiler & $66.77 \%$ & $18.0 \%$ & 1537.3 & 0.0641 & 0.0129 & 3.1721 & 17.4138 & 0.9499 & 0.7172 & 0.0465 & 0.3061 \\
\hline CT & $15.97 \%$ & $13.0 \%$ & 2082.2 & 0.0891 & 0.0179 & 4.0666 & 1.1878 & 0.7691 & 0.1846 & 0.0051 & 0.0413 \\
\hline ICE & $17.25 \%$ & $35.0 \%$ & 771.8 & 0.0330 & 0.0066 & 11.5401 & 0.4458 & 0.2361 & 0.0645 & 0.0074 & 0.0510 \\
\hline \multicolumn{12}{|c|}{ Renewable } \\
\hline WAT & $100.00 \%$ & & & & & & & & & & \\
\hline
\end{tabular}


TABLE 15 (Cont.)

\begin{tabular}{|c|c|c|c|c|c|c|c|c|c|c|c|}
\hline & Technology Share & Efficiency & $\mathrm{CO}_{2}$ & $\mathrm{CH}_{4}$ & $\mathrm{~N}_{2} \mathrm{O}$ & $\mathrm{NO}_{\mathrm{x}}$ & $\mathrm{SO}_{\mathrm{x}}$ & $\mathrm{PM}_{10}$ & $\mathrm{PM}_{2.5}$ & VOC & $\mathrm{CO}$ \\
\hline \multicolumn{12}{|l|}{ HI } \\
\hline Biomass & & $27.8 \%$ & 971.4 & 0.4319 & 0.0576 & 5.0604 & 13.0940 & 2.3436 & 1.6598 & 0.1057 & 3.7299 \\
\hline Boiler & $100.00 \%$ & $27.8 \%$ & 971.4 & 0.4319 & 0.0576 & 5.0604 & 13.0940 & 2.3436 & 1.6598 & 0.1057 & 3.7299 \\
\hline Oil & & $33.9 \%$ & 804.6 & 0.0341 & 0.0068 & 2.1589 & 1.9393 & 0.2224 & 0.1476 & 0.0242 & 0.1594 \\
\hline Boiler & $77.97 \%$ & $33.0 \%$ & 830.1 & 0.0350 & 0.0070 & 1.5700 & 2.3432 & 0.2215 & 0.1750 & 0.0254 & 0.1671 \\
\hline $\mathrm{CT}$ & $17.88 \%$ & $38.4 \%$ & 699.4 & 0.0301 & 0.0060 & 3.1956 & 0.4791 & 0.2602 & 0.0503 & 0.0186 & 0.1247 \\
\hline ICE & $4.16 \%$ & $34.7 \%$ & 778.3 & 0.0333 & 0.0067 & 8.7450 & 0.6427 & 0.0764 & 0.0515 & 0.0254 & 0.1662 \\
\hline \multicolumn{12}{|c|}{ Renewable } \\
\hline GEO & $41.54 \%$ & & & & & & & & & & \\
\hline WAT & $15.43 \%$ & & & & & & & & & & \\
\hline WND & $43.04 \%$ & & & & & & & & & & \\
\hline \multicolumn{12}{|l|}{ IA } \\
\hline Coal & & $32.7 \%$ & 1039.4 & 0.0118 & 0.0177 & 1.2493 & 3.2466 & 0.0407 & 0.0287 & 0.0144 & 0.3995 \\
\hline Boiler & $100.00 \%$ & $32.7 \%$ & 1039.4 & 0.0118 & 0.0177 & 1.2493 & 3.2466 & 0.0407 & 0.0287 & 0.0144 & 0.3995 \\
\hline NG & & $47.9 \%$ & 417.0 & 0.0082 & 0.0008 & 0.2086 & 0.0043 & 0.0102 & 0.0102 & 0.0201 & 0.1110 \\
\hline Boiler & $0.06 \%$ & $26.4 \%$ & 873.8 & 0.0265 & 0.0044 & 11.4634 & 0.4881 & 0.0454 & 0.0454 & 0.0329 & 0.5022 \\
\hline CC & $93.62 \%$ & $49.9 \%$ & 409.1 & 0.0080 & 0.0008 & 0.0445 & 0.0023 & 0.0008 & 0.0008 & 0.0017 & 0.0289 \\
\hline $\mathrm{CT}$ & $4.79 \%$ & $30.5 \%$ & 665.9 & 0.0133 & 0.0014 & 1.0540 & 0.0226 & 0.0372 & 0.0372 & 0.0118 & 0.4619 \\
\hline ICE & $1.53 \%$ & $29.2 \%$ & 109.5 & 0.0031 & 0.0005 & 7.1557 & 0.0536 & 0.4964 & 0.4964 & 1.1681 & 4.0178 \\
\hline \multicolumn{12}{|l|}{ Nuclear } \\
\hline Oil & & $23.7 \%$ & 1149.9 & 0.0488 & 0.0098 & 3.5330 & 1.9573 & 0.4032 & 0.0974 & 0.0035 & 0.0237 \\
\hline $\mathrm{CT}$ & $88.41 \%$ & $23.0 \%$ & 1182.6 & 0.0502 & 0.0101 & 2.2330 & 2.0660 & 0.4330 & 0.1041 & 0.0029 & 0.0233 \\
\hline ICE & $11.59 \%$ & $29.9 \%$ & 900.4 & 0.0384 & 0.0077 & 13.4472 & 1.1284 & 0.1756 & 0.0467 & 0.0080 & 0.0273 \\
\hline
\end{tabular}

Renewable

WAT $\quad 25.87 \%$

WND $\quad 74.13 \%$ 
TABLE 15 (Cont.)

\begin{tabular}{|c|c|c|c|c|c|c|c|c|c|c|c|}
\hline & Technology Share & Efficiency & $\mathrm{CO}_{2}$ & $\mathrm{CH}_{4}$ & $\mathrm{~N}_{2} \mathrm{O}$ & $\mathrm{NO}_{\mathrm{x}}$ & $\mathrm{SO}_{\mathrm{x}}$ & $\mathrm{PM}_{10}$ & $\mathrm{PM}_{2.5}$ & VOC & $\mathrm{CO}$ \\
\hline \multicolumn{12}{|l|}{ ID } \\
\hline NG & & $50.0 \%$ & 410.0 & 0.0080 & 0.0008 & 0.0950 & 0.0021 & 0.0057 & 0.0057 & 0.0029 & 0.0855 \\
\hline CC & $84.14 \%$ & $54.2 \%$ & 376.6 & 0.0074 & 0.0007 & 0.0467 & 0.0019 & 0.0008 & 0.0008 & 0.0016 & 0.0266 \\
\hline CT & $15.86 \%$ & $35.4 \%$ & 587.0 & 0.0113 & 0.0011 & 0.3514 & 0.0029 & 0.0321 & 0.0321 & 0.0102 & 0.3982 \\
\hline Oil & & $34.7 \%$ & 778.2 & 0.0333 & 0.0067 & 11.6363 & 0.9688 & 0.0104 & 0.0104 & 0.0121 & 0.0320 \\
\hline ICE & $100.00 \%$ & $34.7 \%$ & 778.2 & 0.0333 & 0.0067 & 11.6363 & 0.9688 & 0.0104 & 0.0104 & 0.0121 & 0.0320 \\
\hline \multicolumn{12}{|c|}{ Renewable } \\
\hline WAT & $98.13 \%$ & & & & & & & & & & \\
\hline WND & $1.87 \%$ & & & & & & & & & & \\
\hline \multicolumn{12}{|l|}{ IL } \\
\hline Coal & & $33.0 \%$ & 1034.5 & 0.0118 & 0.0176 & 1.1526 & 2.7005 & 0.0711 & 0.0401 & 0.0150 & 0.1216 \\
\hline Boiler & $100.00 \%$ & $33.0 \%$ & 1034.5 & 0.0118 & 0.0176 & 1.1526 & 2.7005 & 0.0711 & 0.0401 & 0.0150 & 0.1216 \\
\hline NG & & $39.7 \%$ & 454.3 & 0.0089 & 0.0009 & 0.3169 & 0.0025 & 0.0419 & 0.0419 & 0.0611 & 0.4200 \\
\hline Boiler & $1.52 \%$ & $31.4 \%$ & 29.2 & 0.0006 & 0.0001 & 2.4441 & 0.0018 & 0.0781 & 0.0781 & 0.0565 & 0.8635 \\
\hline CC & $53.05 \%$ & $47.4 \%$ & 411.9 & 0.0081 & 0.0008 & 0.1089 & 0.0021 & 0.0048 & 0.0048 & 0.0038 & 0.0300 \\
\hline CT & $41.18 \%$ & $34.0 \%$ & 569.0 & 0.0112 & 0.0011 & 0.3045 & 0.0030 & 0.0382 & 0.0382 & 0.0135 & 0.5093 \\
\hline ICE & $4.24 \%$ & $30.3 \%$ & 24.7 & 0.0005 & 0.0001 & 2.2748 & 0.0024 & 0.5281 & 0.5281 & 1.2425 & 4.2739 \\
\hline \multicolumn{12}{|l|}{ Nuclear } \\
\hline Oil & & $28.9 \%$ & 932.2 & 0.0398 & 0.0080 & 11.5834 & 0.6986 & 0.1117 & 0.0335 & 0.0109 & 0.0324 \\
\hline CT & $15.32 \%$ & $23.9 \%$ & 1128.9 & 0.0483 & 0.0097 & 1.7448 & 0.8485 & 0.4170 & 0.1001 & 0.0028 & 0.0224 \\
\hline ICE & $84.68 \%$ & $30.0 \%$ & 896.6 & 0.0383 & 0.0077 & 13.3631 & 0.6715 & 0.0565 & 0.0214 & 0.0124 & 0.0343 \\
\hline \multicolumn{12}{|c|}{ Renewable } \\
\hline WAT & $12.19 \%$ & & & & & & & & & & \\
\hline WND & $87.81 \%$ & & & & & & & & & & \\
\hline
\end{tabular}


TABLE 15 (Cont.)

\begin{tabular}{|c|c|c|c|c|c|c|c|c|c|c|c|}
\hline & Technology Share & Efficiency & $\mathrm{CO}_{2}$ & $\mathrm{CH}_{4}$ & $\mathrm{~N}_{2} \mathrm{O}$ & $\mathrm{NO}_{\mathrm{x}}$ & $\mathrm{SO}_{\mathrm{x}}$ & $\mathrm{PM}_{10}$ & $\mathrm{PM}_{2.5}$ & VOC & $\mathrm{CO}$ \\
\hline \multicolumn{12}{|l|}{ IN } \\
\hline Coal & & $35.3 \%$ & 953.4 & 0.0108 & 0.0162 & 1.4441 & 4.9113 & 0.1537 & 0.1144 & 0.0123 & 0.1042 \\
\hline Boiler & $100.00 \%$ & $35.3 \%$ & 953.4 & 0.0108 & 0.0162 & 1.4441 & 4.9113 & 0.1537 & 0.1144 & 0.0123 & 0.1042 \\
\hline NG & & $36.6 \%$ & 496.5 & 0.0098 & 0.0010 & 0.4455 & 0.0218 & 0.0289 & 0.0289 & 0.0418 & 0.2980 \\
\hline Boiler & $6.14 \%$ & $11.7 \%$ & 1064.9 & 0.0213 & 0.0021 & 3.8156 & 0.3158 & 0.0970 & 0.0970 & 0.0495 & 1.0369 \\
\hline CC & $70.00 \%$ & $48.1 \%$ & 423.9 & 0.0083 & 0.0008 & 0.0733 & 0.0021 & 0.0009 & 0.0009 & 0.0018 & 0.0300 \\
\hline CT & $20.84 \%$ & $31.7 \%$ & 644.2 & 0.0126 & 0.0013 & 0.4009 & 0.0042 & 0.0358 & 0.0358 & 0.0114 & 0.4447 \\
\hline ICE & $3.01 \%$ & $31.0 \%$ & 3.4 & 0.0001 & 0.0000 & 2.5320 & 0.0007 & 0.4953 & 0.4953 & 1.1654 & 4.0086 \\
\hline Oil & & $34.0 \%$ & 794.6 & 0.0340 & 0.0068 & 11.8820 & 0.9893 & 0.0791 & 0.0533 & 0.0261 & 0.1718 \\
\hline ICE & $100.00 \%$ & $34.0 \%$ & 794.6 & 0.0340 & 0.0068 & 11.8820 & 0.9893 & 0.0791 & 0.0533 & 0.0261 & 0.1718 \\
\hline \multicolumn{12}{|c|}{ Renewable } \\
\hline WAT & $55.33 \%$ & & & & & & & & & & \\
\hline WH & $44.67 \%$ & & & & & & & & & & \\
\hline \multicolumn{12}{|l|}{ KS } \\
\hline Coal & & $33.0 \%$ & 1032.5 & 0.0117 & 0.0175 & 1.6656 & 2.8674 & 0.0436 & 0.0347 & 0.0147 & 0.1244 \\
\hline Boiler & $100.00 \%$ & $33.0 \%$ & 1032.5 & 0.0117 & 0.0175 & 1.6656 & 2.8674 & 0.0436 & 0.0347 & 0.0147 & 0.1244 \\
\hline NG & & $30.6 \%$ & 669.0 & 0.0132 & 0.0013 & 1.4620 & 0.0076 & 0.0435 & 0.0435 & 0.0383 & 0.4724 \\
\hline Boiler & $85.34 \%$ & $31.3 \%$ & 653.3 & 0.0128 & 0.0013 & 1.3585 & 0.0039 & 0.0383 & 0.0383 & 0.0277 & 0.4229 \\
\hline $\mathrm{CT}$ & $12.71 \%$ & $26.7 \%$ & 760.4 & 0.0150 & 0.0015 & 1.0064 & 0.0099 & 0.0424 & 0.0424 & 0.0135 & 0.5271 \\
\hline ICE & $1.95 \%$ & $27.5 \%$ & 759.8 & 0.0176 & 0.0022 & 8.9752 & 0.1532 & 0.2824 & 0.2824 & 0.6645 & 2.2856 \\
\hline \multicolumn{12}{|l|}{ Nuclear } \\
\hline Oil & & $33.5 \%$ & 803.2 & 0.0342 & 0.0068 & 11.9819 & 0.9629 & 0.1359 & 0.0373 & 0.0080 & 0.0257 \\
\hline ICE & $100.00 \%$ & $33.5 \%$ & 803.2 & 0.0342 & 0.0068 & 11.9819 & 0.9629 & 0.1359 & 0.0373 & 0.0080 & 0.0257 \\
\hline \multicolumn{12}{|c|}{ Renewable } \\
\hline WAT & $0.90 \%$ & & & & & & & & & & \\
\hline WND & $99.10 \%$ & & & & & & & & & & \\
\hline
\end{tabular}


TABLE 15 (Cont.)

\begin{tabular}{|c|c|c|c|c|c|c|c|c|c|c|c|}
\hline & Technology Share & Efficiency & $\mathrm{CO}_{2}$ & $\mathrm{CH}_{4}$ & $\mathrm{~N}_{2} \mathrm{O}$ & $\mathrm{NO}_{\mathrm{x}}$ & $\mathrm{SO}_{\mathrm{x}}$ & $\mathrm{PM}_{10}$ & $\mathrm{PM}_{2.5}$ & VOC & $\mathrm{CO}$ \\
\hline \multicolumn{12}{|l|}{ KY } \\
\hline Coal & & $34.0 \%$ & 974.7 & 0.0111 & 0.0165 & 1.6806 & 3.6556 & 0.1943 & 0.1524 & 0.0139 & 0.1019 \\
\hline Boiler & $100.00 \%$ & $34.0 \%$ & 974.7 & 0.0111 & 0.0165 & 1.6806 & 3.6556 & 0.1943 & 0.1524 & 0.0139 & 0.1019 \\
\hline NG & & $28.6 \%$ & 632.7 & 0.0123 & 0.0012 & 0.5963 & 0.0067 & 0.0923 & 0.0923 & 0.1403 & 0.9293 \\
\hline Boiler & $2.28 \%$ & $30.6 \%$ & 0.0 & 0.0000 & 0.0000 & 2.5581 & 0.0000 & 0.1396 & 0.1396 & 0.0730 & 2.4722 \\
\hline $\mathrm{CT}$ & $87.16 \%$ & $28.2 \%$ & 725.9 & 0.0142 & 0.0014 & 0.3157 & 0.0077 & 0.0401 & 0.0401 & 0.0128 & 0.4985 \\
\hline ICE & $10.56 \%$ & $31.4 \%$ & 0.0 & 0.0000 & 0.0000 & 2.4889 & 0.0000 & 0.5131 & 0.5131 & 1.2072 & 4.1525 \\
\hline Oil & & $27.9 \%$ & 966.5 & 0.0414 & 0.0083 & 14.4518 & 2.2808 & 0.0130 & 0.0130 & 0.0150 & 0.0397 \\
\hline ICE & $100.00 \%$ & $27.9 \%$ & 966.5 & 0.0414 & 0.0083 & 14.4518 & 2.2808 & 0.0130 & 0.0130 & 0.0150 & 0.0397 \\
\hline \multicolumn{12}{|c|}{ Renewable } \\
\hline WAT & $100.00 \%$ & & & & & & & & & & \\
\hline \multicolumn{12}{|l|}{ LA } \\
\hline Coal & & $34.4 \%$ & 997.5 & 0.0113 & 0.0165 & 1.1278 & 2.7651 & 0.0752 & 0.0479 & 0.0160 & 0.1343 \\
\hline Boiler & $100.00 \%$ & $34.4 \%$ & 997.5 & 0.0113 & 0.0165 & 1.1278 & 2.7651 & 0.0752 & 0.0479 & 0.0160 & 0.1343 \\
\hline NG & & $34.5 \%$ & 593.9 & 0.0120 & 0.0013 & 1.0035 & 0.0926 & 0.0252 & 0.0252 & 0.0181 & 0.2942 \\
\hline Boiler & $55.82 \%$ & $28.9 \%$ & 712.7 & 0.0146 & 0.0016 & 1.6135 & 0.1630 & 0.0407 & 0.0407 & 0.0300 & 0.4585 \\
\hline $\mathrm{CC}$ & $38.91 \%$ & $50.5 \%$ & 403.8 & 0.0079 & 0.0008 & 0.0870 & 0.0020 & 0.0008 & 0.0008 & 0.0017 & 0.0286 \\
\hline CT & $5.27 \%$ & $27.3 \%$ & 739.3 & 0.0147 & 0.0015 & 1.3071 & 0.0151 & 0.0415 & 0.0415 & 0.0132 & 0.5157 \\
\hline ICE & $0.00 \%$ & $32.8 \%$ & 728.4 & 0.0239 & 0.0042 & 9.8213 & 0.5386 & 0.2371 & 0.2371 & 0.5578 & 1.9186 \\
\hline \multicolumn{12}{|l|}{ Nuclear } \\
\hline Oil & & $31.1 \%$ & 868.4 & 0.0372 & 0.0075 & 12.9849 & 1.1202 & 0.0116 & 0.0116 & 0.0135 & 0.0357 \\
\hline ICE & $100.00 \%$ & $31.1 \%$ & 868.4 & 0.0372 & 0.0075 & 12.9849 & 1.1202 & 0.0116 & 0.0116 & 0.0135 & 0.0357 \\
\hline \multicolumn{12}{|c|}{ Renewable } \\
\hline WAT & $97.68 \%$ & & & & & & & & & & \\
\hline WH & $2.32 \%$ & & & & & & & & & & \\
\hline
\end{tabular}


TABLE 15 (Cont.)

\begin{tabular}{|c|c|c|c|c|c|c|c|c|c|c|c|}
\hline & Technology Share & Efficiency & $\mathrm{CO}_{2}$ & $\mathrm{CH}_{4}$ & $\mathrm{~N}_{2} \mathrm{O}$ & $\mathrm{NO}_{\mathrm{x}}$ & $\mathrm{SO}_{\mathrm{x}}$ & $\mathrm{PM}_{10}$ & $\mathrm{PM}_{2.5}$ & VOC & $\mathrm{CO}$ \\
\hline \multicolumn{12}{|l|}{ MA } \\
\hline Biomass & & $22.5 \%$ & 1265.2 & 0.5357 & 0.0714 & 6.2911 & 17.1006 & 2.8814 & 2.0775 & 0.1310 & 4.6247 \\
\hline Boiler & $100.00 \%$ & $22.5 \%$ & 1265.2 & 0.5357 & 0.0714 & 6.2911 & 17.1006 & 2.8814 & 2.0775 & 0.1310 & 4.6247 \\
\hline Coal & & $37.5 \%$ & 883.9 & 0.0105 & 0.0149 & 0.5623 & 3.3132 & 0.0890 & 0.0793 & 0.0111 & 0.0924 \\
\hline Boiler & $100.00 \%$ & $37.5 \%$ & 883.9 & 0.0105 & 0.0149 & 0.5623 & 3.3132 & 0.0890 & 0.0793 & 0.0111 & 0.0924 \\
\hline NG & & $50.2 \%$ & 406.7 & 0.0079 & 0.0008 & 0.0692 & 0.0866 & 0.0036 & 0.0036 & 0.0068 & 0.0546 \\
\hline Boiler & $1.31 \%$ & $32.1 \%$ & 645.0 & 0.0150 & 0.0019 & 0.8774 & 0.4158 & 0.0385 & 0.0385 & 0.0278 & 0.4251 \\
\hline $\mathrm{CC}$ & $98.15 \%$ & $50.8 \%$ & 405.6 & 0.0079 & 0.0008 & 0.0532 & 0.0826 & 0.0008 & 0.0008 & 0.0017 & 0.0284 \\
\hline CT & $0.22 \%$ & $31.9 \%$ & 41.0 & 0.0013 & 0.0002 & 0.3644 & 0.0135 & 0.1281 & 0.1281 & 0.0666 & 2.2577 \\
\hline ICE & $0.32 \%$ & $27.0 \%$ & 3.8 & 0.0001 & 0.0000 & 1.4596 & 0.0012 & 0.6256 & 0.6256 & 1.4719 & 5.0630 \\
\hline \multicolumn{12}{|l|}{ Nuclear } \\
\hline Oil & & $32.6 \%$ & 811.8 & 0.0347 & 0.0069 & 0.4477 & 2.6271 & 0.0688 & 0.0635 & 0.0257 & 0.1687 \\
\hline Boiler & $99.71 \%$ & $32.6 \%$ & 810.4 & 0.0346 & 0.0069 & 0.4337 & 2.6328 & 0.0679 & 0.0632 & 0.0257 & 0.1691 \\
\hline $\mathrm{CT}$ & $0.11 \%$ & $13.1 \%$ & 2050.2 & 0.0884 & 0.0177 & 3.2072 & 0.9765 & 0.7563 & 0.4139 & 0.0235 & 0.0414 \\
\hline ICE & $0.18 \%$ & $34.1 \%$ & 791.2 & 0.0339 & 0.0068 & 6.5703 & 0.4925 & 0.1138 & 0.0324 & 0.0085 & 0.0264 \\
\hline \multicolumn{12}{|l|}{ MD } \\
\hline Biomass & & $21.6 \%$ & 1497.2 & 0.5571 & 0.0742 & 7.0676 & 20.1164 & 3.0275 & 2.1441 & 0.1365 & 4.8183 \\
\hline Boiler & $100.00 \%$ & $21.6 \%$ & 1497.2 & 0.5571 & 0.0742 & 7.0676 & 20.1164 & 3.0275 & 2.1441 & 0.1365 & 4.8183 \\
\hline Coal & & $35.8 \%$ & 911.2 & 0.0112 & 0.0151 & 1.5333 & 8.3590 & 0.6151 & 0.2957 & 0.0120 & 0.0944 \\
\hline Boiler & $100.00 \%$ & $35.8 \%$ & 911.2 & 0.0112 & 0.0151 & 1.5333 & 8.3590 & 0.6151 & 0.2957 & 0.0120 & 0.0944 \\
\hline NG & & $29.2 \%$ & 638.2 & 0.0131 & 0.0014 & 0.6636 & 0.0332 & 0.0840 & 0.0840 & 0.1255 & 0.8340 \\
\hline $\mathrm{CT}$ & $93.96 \%$ & $30.0 \%$ & 679.2 & 0.0139 & 0.0015 & 0.5870 & 0.0353 & 0.0378 & 0.0378 & 0.0120 & 0.4694 \\
\hline ICE & $6.04 \%$ & $21.1 \%$ & 0.0 & 0.0000 & 0.0000 & 1.8552 & 0.0000 & 0.8035 & 0.8035 & 1.8907 & 6.5033 \\
\hline
\end{tabular}


TABLE 15 (Cont.)

\begin{tabular}{|c|c|c|c|c|c|c|c|c|c|c|c|}
\hline & Technology Share & Efficiency & $\mathrm{CO}_{2}$ & $\mathrm{CH}_{4}$ & $\mathrm{~N}_{2} \mathrm{O}$ & $\mathrm{NO}_{\mathrm{x}}$ & $\mathrm{SO}_{\mathrm{x}}$ & $\mathrm{PM}_{10}$ & $\mathrm{PM}_{2.5}$ & VOC & $\mathrm{CO}$ \\
\hline \multicolumn{12}{|l|}{ MD (cont.) } \\
\hline \multicolumn{12}{|l|}{ Nuclear } \\
\hline Oil & & $25.8 \%$ & 1043.4 & 0.0447 & 0.0090 & 3.8090 & 5.9970 & 0.3179 & 0.1693 & 0.0184 & 0.1111 \\
\hline Boiler & $39.41 \%$ & $22.7 \%$ & 1184.2 & 0.0509 & 0.0102 & 2.0808 & 12.8241 & 0.4327 & 0.3351 & 0.0369 & 0.2430 \\
\hline $\mathrm{CT}$ & $18.93 \%$ & $21.5 \%$ & 1256.3 & 0.0538 & 0.0108 & 1.9417 & 1.4064 & 0.4640 & 0.1114 & 0.0031 & 0.0249 \\
\hline ICE & $41.66 \%$ & $33.3 \%$ & 813.5 & 0.0347 & 0.0070 & 6.2928 & 1.6238 & 0.1427 & 0.0387 & 0.0078 & 0.0254 \\
\hline \multicolumn{12}{|c|}{ Renewable } \\
\hline WAT & $100.00 \%$ & & & & & & & & & & \\
\hline \multicolumn{12}{|l|}{ ME } \\
\hline Biomass & & $20.6 \%$ & 234.2 & 0.5843 & 0.0779 & 2.5758 & 3.2744 & 2.8262 & 2.5159 & 0.1428 & 5.0406 \\
\hline Boiler & $100.00 \%$ & $20.6 \%$ & 234.2 & 0.5843 & 0.0779 & 2.5758 & 3.2744 & 2.8262 & 2.5159 & 0.1428 & 5.0406 \\
\hline NG & & $52.6 \%$ & 387.7 & 0.0076 & 0.0008 & 0.0419 & 0.0020 & 0.0008 & 0.0008 & 0.0016 & 0.0272 \\
\hline CC & $100.00 \%$ & $52.6 \%$ & 387.7 & 0.0076 & 0.0008 & 0.0419 & 0.0020 & 0.0008 & 0.0008 & 0.0016 & 0.0272 \\
\hline Oil & & $33.4 \%$ & 855.9 & 0.0346 & 0.0069 & 0.7455 & 3.9365 & 0.0670 & 0.0654 & 0.0249 & 0.1636 \\
\hline Boiler & $99.18 \%$ & $33.5 \%$ & 854.2 & 0.0345 & 0.0069 & 0.7200 & 3.9505 & 0.0653 & 0.0653 & 0.0250 & 0.1647 \\
\hline $\mathrm{CT}$ & $0.48 \%$ & $21.6 \%$ & 1251.4 & 0.0536 & 0.0107 & 1.9341 & 2.6554 & 0.4622 & 0.1110 & 0.0031 & 0.0248 \\
\hline ICE & $0.34 \%$ & $34.7 \%$ & 776.7 & 0.0332 & 0.0067 & 6.4498 & 1.6579 & 0.0104 & 0.0104 & 0.0121 & 0.0319 \\
\hline \multicolumn{12}{|c|}{ Renewable } \\
\hline WAT & $97.22 \%$ & & & & & & & & & & \\
\hline WND & $2.78 \%$ & & & & & & & & & & \\
\hline \multicolumn{12}{|l|}{ MI } \\
\hline Biomass & & $26.0 \%$ & 53.4 & 0.4638 & 0.0618 & 2.0917 & 1.3440 & 2.1736 & 2.0406 & 0.1130 & 3.9882 \\
\hline Boiler & $100.00 \%$ & $26.0 \%$ & 53.4 & 0.4638 & 0.0618 & 2.0917 & 1.3440 & 2.1736 & 2.0406 & 0.1130 & 3.9882 \\
\hline Coal & & $34.5 \%$ & 983.5 & 0.0113 & 0.0167 & 1.3722 & 4.4021 & 0.0732 & 0.0383 & 0.0142 & 0.1182 \\
\hline Boiler & $100.00 \%$ & $34.5 \%$ & 983.5 & 0.0113 & 0.0167 & 1.3722 & 4.4021 & 0.0732 & 0.0383 & 0.0142 & 0.1182 \\
\hline
\end{tabular}


TABLE 15 (Cont.)

\begin{tabular}{|c|c|c|c|c|c|c|c|c|c|c|c|}
\hline & Technology Share & Efficiency & $\mathrm{CO}_{2}$ & $\mathrm{CH}_{4}$ & $\mathrm{~N}_{2} \mathrm{O}$ & $\mathrm{NO}_{\mathrm{x}}$ & $\mathrm{SO}_{\mathrm{x}}$ & $\mathrm{PM}_{10}$ & $\mathrm{PM}_{2.5}$ & VOC & $\mathrm{CO}$ \\
\hline \multicolumn{12}{|l|}{ MI (cont.) } \\
\hline NG & & $37.6 \%$ & 520.8 & 0.0094 & 0.0009 & 0.4227 & 0.1302 & 0.0509 & 0.0509 & 0.0893 & 0.4392 \\
\hline Boiler & $14.21 \%$ & $25.1 \%$ & 1080.9 & 0.0154 & 0.0015 & 0.9379 & 0.8944 & 0.0502 & 0.0502 & 0.0363 & 0.5548 \\
\hline $\mathrm{CC}$ & $64.03 \%$ & $45.7 \%$ & 416.4 & 0.0082 & 0.0008 & 0.1197 & 0.0021 & 0.0072 & 0.0072 & 0.0051 & 0.0306 \\
\hline CT & $15.64 \%$ & $32.1 \%$ & 635.3 & 0.0125 & 0.0012 & 0.3263 & 0.0054 & 0.0353 & 0.0353 & 0.0112 & 0.4386 \\
\hline ICE & $6.12 \%$ & $30.5 \%$ & 19.1 & 0.0005 & 0.0001 & 2.6439 & 0.0138 & 0.5496 & 0.5496 & 1.2931 & 4.4479 \\
\hline \multicolumn{12}{|l|}{ Nuclear } \\
\hline Oil & & $23.0 \%$ & 1174.2 & 0.0503 & 0.0101 & 10.1148 & 1.4783 & 0.2579 & 0.0669 & 0.0094 & 0.0338 \\
\hline CT & $39.78 \%$ & $19.3 \%$ & 1401.3 & 0.0600 & 0.0120 & 2.2429 & 1.7555 & 0.5176 & 0.1243 & 0.0035 & 0.0278 \\
\hline ICE & $60.22 \%$ & $26.4 \%$ & 1024.2 & 0.0438 & 0.0088 & 15.3148 & 1.2951 & 0.0864 & 0.0291 & 0.0133 & 0.0378 \\
\hline \multicolumn{12}{|c|}{ Renewable } \\
\hline WAT & $97.83 \%$ & & & & & & & & & & \\
\hline WND & $2.17 \%$ & & & & & & & & & & \\
\hline \multicolumn{12}{|l|}{ MN } \\
\hline Biomass & & $19.5 \%$ & 1048.4 & 0.6146 & 0.0819 & 5.5020 & 14.2236 & 3.3537 & 2.3752 & 0.1512 & 5.3375 \\
\hline Boiler & $100.00 \%$ & $19.5 \%$ & 1048.4 & 0.6146 & 0.0819 & 5.5020 & 14.2236 & 3.3537 & 2.3752 & 0.1512 & 5.3375 \\
\hline Coal & & $30.0 \%$ & 1136.8 & 0.0129 & 0.0193 & 2.7691 & 3.4729 & 0.0973 & 0.0372 & 0.0164 & 0.1363 \\
\hline Boiler & $100.00 \%$ & $30.0 \%$ & 1136.8 & 0.0129 & 0.0193 & 2.7691 & 3.4729 & 0.0973 & 0.0372 & 0.0164 & 0.1363 \\
\hline NG & & $37.7 \%$ & 530.7 & 0.0114 & 0.0013 & 0.4623 & 0.0104 & 0.0249 & 0.0249 & 0.0143 & 0.2598 \\
\hline Boiler & $2.16 \%$ & $29.1 \%$ & 694.5 & 0.0141 & 0.0015 & 5.0856 & 0.0310 & 0.0633 & 0.0633 & 0.0458 & 0.6994 \\
\hline $\mathrm{CC}$ & $50.07 \%$ & $47.7 \%$ & 396.6 & 0.0077 & 0.0008 & 0.1333 & 0.0096 & 0.0085 & 0.0085 & 0.0057 & 0.0293 \\
\hline $\mathrm{CT}$ & $47.38 \%$ & $31.4 \%$ & 668.1 & 0.0153 & 0.0019 & 0.5374 & 0.0103 & 0.0361 & 0.0361 & 0.0115 & 0.4490 \\
\hline ICE & $0.40 \%$ & $27.4 \%$ & 163.4 & 0.0048 & 0.0008 & 7.8645 & 0.0072 & 0.5342 & 0.5342 & 1.2569 & 4.3233 \\
\hline \multicolumn{12}{|l|}{ Nuclear } \\
\hline Oil & & $25.7 \%$ & 1050.5 & 0.0450 & 0.0090 & 7.8479 & 0.0655 & 0.2727 & 0.0715 & 0.0084 & 0.0417 \\
\hline CT & $43.71 \%$ & $19.3 \%$ & 1398.0 & 0.0598 & 0.0120 & 2.9939 & 0.0871 & 0.5164 & 0.1240 & 0.0034 & 0.0278 \\
\hline ICE & $56.29 \%$ & $34.6 \%$ & 780.7 & 0.0334 & 0.0067 & 11.6172 & 0.0488 & 0.0835 & 0.0308 & 0.0123 & 0.0525 \\
\hline
\end{tabular}


TABLE 15 (Cont.)

\begin{tabular}{|c|c|c|c|c|c|c|c|c|c|c|c|}
\hline & Technology Share & Efficiency & $\mathrm{CO}_{2}$ & $\mathrm{CH}_{4}$ & $\mathrm{~N}_{2} \mathrm{O}$ & $\mathrm{NO}_{\mathrm{x}}$ & $\mathrm{SO}_{\mathrm{x}}$ & $\mathrm{PM}_{10}$ & $\mathrm{PM}_{2.5}$ & VOC & $\mathrm{CO}$ \\
\hline \multicolumn{12}{|l|}{ MN (cont.) } \\
\hline \multicolumn{12}{|c|}{ Renewable } \\
\hline WAT & $18.35 \%$ & & & & & & & & & & \\
\hline WND & $81.65 \%$ & & & & & & & & & & \\
\hline \multicolumn{12}{|l|}{ MO } \\
\hline Coal & & $35.8 \%$ & 950.6 & 0.0108 & 0.0161 & 1.2901 & 3.1571 & 0.0818 & 0.0409 & 0.0137 & 0.1159 \\
\hline Boiler & $100.00 \%$ & $35.8 \%$ & 950.6 & 0.0108 & 0.0161 & 1.2901 & 3.1571 & 0.0818 & 0.0409 & 0.0137 & 0.1159 \\
\hline NG & & $45.6 \%$ & 444.9 & 0.0087 & 0.0009 & 0.1437 & 0.0038 & 0.0074 & 0.0074 & 0.0052 & 0.1042 \\
\hline Boiler & $0.51 \%$ & $44.4 \%$ & 0.0 & 0.0000 & 0.0000 & 0.2155 & 0.0000 & 0.0546 & 0.0546 & 0.0395 & 0.6034 \\
\hline CC & $83.41 \%$ & $50.1 \%$ & 407.3 & 0.0080 & 0.0008 & 0.0536 & 0.0021 & 0.0008 & 0.0008 & 0.0017 & 0.0288 \\
\hline СT & $15.74 \%$ & $31.1 \%$ & 655.9 & 0.0130 & 0.0013 & 0.4788 & 0.0123 & 0.0364 & 0.0364 & 0.0116 & 0.4521 \\
\hline ICE & $0.34 \%$ & $36.1 \%$ & 564.3 & 0.0119 & 0.0013 & 6.6297 & 0.0504 & 0.2155 & 0.2155 & 0.5071 & 1.7441 \\
\hline \multicolumn{12}{|l|}{ Nuclear } \\
\hline Oil & & $15.0 \%$ & 1793.4 & 0.0768 & 0.0154 & 20.8556 & 2.2615 & 0.6299 & 0.1777 & 0.0445 & 0.1390 \\
\hline $\mathrm{CT}$ & $61.48 \%$ & $11.2 \%$ & 2417.6 & 0.1035 & 0.0208 & 26.4538 & 3.0512 & 0.8930 & 0.2144 & 0.0060 & 0.0480 \\
\hline ICE & $38.52 \%$ & $33.8 \%$ & 797.3 & 0.0341 & 0.0068 & 11.9220 & 1.0014 & 0.2100 & 0.1193 & 0.1061 & 0.2842 \\
\hline \multicolumn{12}{|c|}{ Renewable } \\
\hline WAT & $100.00 \%$ & & & & & & & & & & \\
\hline \multicolumn{12}{|l|}{ MS } \\
\hline Coal & & $33.7 \%$ & 960.0 & 0.0113 & 0.0152 & 1.7260 & 2.9583 & 0.2278 & 0.1871 & 0.0142 & 0.1191 \\
\hline Boiler & $100.00 \%$ & $33.7 \%$ & 960.0 & 0.0113 & 0.0152 & 1.7260 & 2.9583 & 0.2278 & 0.1871 & 0.0142 & 0.1191 \\
\hline NG & & $43.4 \%$ & 476.0 & 0.0106 & 0.0013 & 0.5531 & 0.1406 & 0.0106 & 0.0106 & 0.0082 & 0.1324 \\
\hline Boiler & $24.41 \%$ & $31.2 \%$ & 675.8 & 0.0184 & 0.0027 & 2.0529 & 0.5695 & 0.0384 & 0.0384 & 0.0278 & 0.4244 \\
\hline CC & $74.09 \%$ & $50.4 \%$ & 405.0 & 0.0079 & 0.0008 & 0.0626 & 0.0020 & 0.0008 & 0.0008 & 0.0017 & 0.0287 \\
\hline $\mathrm{CT}$ & $1.51 \%$ & $28.1 \%$ & 728.2 & 0.0159 & 0.0018 & 0.3815 & 0.0078 & 0.0403 & 0.0403 & 0.0128 & 0.5011 \\
\hline Nuclear & & & & & & & & & & & \\
\hline
\end{tabular}


TABLE 15 (Cont.)

\begin{tabular}{|c|c|c|c|c|c|c|c|c|c|c|c|}
\hline & Technology Share & Efficiency & $\mathrm{CO}_{2}$ & $\mathrm{CH}_{4}$ & $\mathrm{~N}_{2} \mathrm{O}$ & $\mathrm{NO}_{\mathrm{x}}$ & $\mathrm{SO}_{\mathrm{x}}$ & $\mathrm{PM}_{10}$ & $\mathrm{PM}_{2.5}$ & VOC & $\mathrm{CO}$ \\
\hline \multicolumn{12}{|l|}{ MT } \\
\hline Coal & & $30.3 \%$ & 1126.7 & 0.0128 & 0.0191 & 2.1002 & 1.4369 & 0.8217 & 0.2994 & 0.0166 & 0.1326 \\
\hline Boiler & $100.00 \%$ & $30.3 \%$ & 1126.7 & 0.0128 & 0.0191 & 2.1002 & 1.4369 & 0.8217 & 0.2994 & 0.0166 & 0.1326 \\
\hline NG & & $37.5 \%$ & 536.4 & 0.0108 & 0.0011 & 5.8776 & 0.0242 & 0.1962 & 0.1962 & 0.4579 & 1.5955 \\
\hline CT & $3.16 \%$ & $19.7 \%$ & 1044.2 & 0.0229 & 0.0027 & 2.4228 & 0.3156 & 0.0575 & 0.0575 & 0.0183 & 0.7140 \\
\hline ICE & $96.84 \%$ & $38.6 \%$ & 519.8 & 0.0104 & 0.0010 & 5.9902 & 0.0147 & 0.2007 & 0.2007 & 0.4722 & 1.6242 \\
\hline \multicolumn{12}{|c|}{ Renewable } \\
\hline WAT & $94.97 \%$ & & & & & & & & & & \\
\hline WND & $5.03 \%$ & & & & & & & & & & \\
\hline \multicolumn{12}{|l|}{ NC } \\
\hline Coal & & $37.6 \%$ & 882.5 & 0.0101 & 0.0150 & 0.6795 & 4.3650 & 0.2764 & 0.2339 & 0.0110 & 0.0920 \\
\hline Boiler & $100.00 \%$ & $37.6 \%$ & 882.5 & 0.0101 & 0.0150 & 0.6795 & 4.3650 & 0.2764 & 0.2339 & 0.0110 & 0.0920 \\
\hline NG & & $38.8 \%$ & 522.7 & 0.0105 & 0.0011 & 0.3040 & 0.0075 & 0.0293 & 0.0293 & 0.0097 & 0.3707 \\
\hline Boiler & $0.16 \%$ & $38.8 \%$ & 109.7 & 0.0047 & 0.0009 & 3.3477 & 0.0208 & 0.0814 & 0.0814 & 0.0589 & 0.8999 \\
\hline $\mathrm{CC}$ & $2.24 \%$ & $29.6 \%$ & 679.6 & 0.0137 & 0.0014 & 0.5480 & 0.0208 & 0.0014 & 0.0014 & 0.0029 & 0.0488 \\
\hline $\mathrm{CT}$ & $97.60 \%$ & $39.1 \%$ & 519.8 & 0.0104 & 0.0011 & 0.2935 & 0.0072 & 0.0298 & 0.0298 & 0.0097 & 0.3772 \\
\hline \multicolumn{12}{|l|}{ Nuclear } \\
\hline Oil & & $22.1 \%$ & 1222.0 & 0.0523 & 0.0105 & 14.2174 & 0.2269 & 0.3003 & 0.0804 & 0.0109 & 0.0537 \\
\hline CT & $16.51 \%$ & $14.7 \%$ & 1831.6 & 0.0784 & 0.0157 & 2.8310 & 0.3391 & 0.6766 & 0.1624 & 0.0045 & 0.0364 \\
\hline ICE & $83.49 \%$ & $24.5 \%$ & 1101.4 & 0.0472 & 0.0095 & 16.4697 & 0.2047 & 0.2259 & 0.0642 & 0.0122 & 0.0571 \\
\hline \multicolumn{12}{|c|}{ Renewable } \\
\hline WAT & $100.00 \%$ & & & & & & & & & & \\
\hline \multicolumn{12}{|l|}{ ND } \\
\hline Coal & & $34.0 \%$ & 1081.6 & 0.0116 & 0.0174 & 2.1884 & 4.2500 & 0.2448 & 0.2442 & 0.0228 & 0.0920 \\
\hline Boiler & $100.00 \%$ & $34.0 \%$ & 1081.6 & 0.0116 & 0.0174 & 2.1884 & 4.2500 & 0.2448 & 0.2442 & 0.0228 & 0.0920 \\
\hline
\end{tabular}


TABLE 15 (Cont.)

\begin{tabular}{|c|c|c|c|c|c|c|c|c|c|c|c|}
\hline & Technology Share & Efficiency & $\mathrm{CO}_{2}$ & $\mathrm{CH}_{4}$ & $\mathrm{~N}_{2} \mathrm{O}$ & $\mathrm{NO}_{\mathrm{x}}$ & $\mathrm{SO}_{\mathrm{x}}$ & $\mathrm{PM}_{10}$ & $\mathrm{PM}_{2.5}$ & VOC & $\mathrm{CO}$ \\
\hline \multicolumn{12}{|l|}{ ND (cont.) } \\
\hline Oil & & $18.4 \%$ & 1465.4 & 0.0627 & 0.0126 & 3.7865 & 1.7777 & 0.5359 & 0.1288 & 0.0038 & 0.0294 \\
\hline CT & $91.01 \%$ & $17.7 \%$ & 1525.9 & 0.0653 & 0.0131 & 2.9012 & 1.8474 & 0.5636 & 0.1353 & 0.0038 & 0.0303 \\
\hline ICE & $8.99 \%$ & $31.7 \%$ & 852.6 & 0.0365 & 0.0073 & 12.7485 & 1.0717 & 0.2553 & 0.0630 & 0.0043 & 0.0205 \\
\hline \multicolumn{12}{|c|}{ Renewable } \\
\hline WAT & $67.77 \%$ & & & & & & & & & & \\
\hline WND & $32.23 \%$ & & & & & & & & & & \\
\hline \multicolumn{12}{|l|}{ NE } \\
\hline Coal & & $32.5 \%$ & 1051.2 & 0.0119 & 0.0179 & 1.8677 & 3.1770 & 0.0258 & 0.0194 & 0.0152 & 0.1265 \\
\hline Boiler & $100.00 \%$ & $32.5 \%$ & 1051.2 & 0.0119 & 0.0179 & 1.8677 & 3.1770 & 0.0258 & 0.0194 & 0.0152 & 0.1265 \\
\hline NG & & $35.7 \%$ & 548.7 & 0.0107 & 0.0011 & 0.6653 & 0.0729 & 0.0409 & 0.0409 & 0.0686 & 0.4024 \\
\hline Boiler & $10.17 \%$ & $29.0 \%$ & 743.3 & 0.0138 & 0.0014 & 1.4036 & 0.6607 & 0.0413 & 0.0413 & 0.0299 & 0.4566 \\
\hline $\mathrm{CC}$ & $55.46 \%$ & $40.3 \%$ & 507.4 & 0.0099 & 0.0010 & 0.0687 & 0.0036 & 0.0010 & 0.0010 & 0.0021 & 0.0358 \\
\hline CT & $29.16 \%$ & $32.7 \%$ & 626.5 & 0.0122 & 0.0012 & 0.3772 & 0.0079 & 0.0346 & 0.0346 & 0.0110 & 0.4301 \\
\hline ICE & $5.21 \%$ & $28.9 \%$ & 173.0 & 0.0038 & 0.0005 & 7.1904 & 0.0261 & 0.4997 & 0.4997 & 1.1757 & 4.0441 \\
\hline \multicolumn{12}{|l|}{ Nuclear } \\
\hline Oil & & $26.1 \%$ & 1031.7 & 0.0441 & 0.0088 & 8.8264 & 1.2866 & 0.1952 & 0.0522 & 0.0094 & 0.0317 \\
\hline $\mathrm{CT}$ & $31.67 \%$ & $16.9 \%$ & 1593.0 & 0.0682 & 0.0137 & 3.0288 & 1.9625 & 0.5884 & 0.1412 & 0.0039 & 0.0316 \\
\hline ICE & $68.33 \%$ & $34.9 \%$ & 771.6 & 0.0329 & 0.0066 & 11.5139 & 0.9733 & 0.0130 & 0.0109 & 0.0120 & 0.0317 \\
\hline \multicolumn{12}{|c|}{ Renewable } \\
\hline WAT & $79.13 \%$ & & & & & & & & & & \\
\hline WND & $20.87 \%$ & & & & & & & & & & \\
\hline \multicolumn{12}{|l|}{ NH } \\
\hline Biomass & & $24.4 \%$ & 287.0 & 0.4960 & 0.0661 & 2.9846 & 4.0552 & 2.4007 & 2.1212 & 0.1208 & 4.2650 \\
\hline Boiler & $100.00 \%$ & $24.4 \%$ & 287.0 & 0.4960 & 0.0661 & 2.9846 & 4.0552 & 2.4007 & 2.1212 & 0.1208 & 4.2650 \\
\hline Coal & & $32.4 \%$ & 1028.3 & 0.0117 & 0.0175 & 0.8884 & 10.0655 & 0.0386 & 0.0042 & 0.0235 & 0.1069 \\
\hline Boiler & $100.00 \%$ & $32.4 \%$ & 1028.3 & 0.0117 & 0.0175 & 0.8884 & 10.0655 & 0.0386 & 0.0042 & 0.0235 & 0.1069 \\
\hline
\end{tabular}


TABLE 15 (Cont.)

\begin{tabular}{|c|c|c|c|c|c|c|c|c|c|c|c|}
\hline & Technology Share & Efficiency & $\mathrm{CO}_{2}$ & $\mathrm{CH}_{4}$ & $\mathrm{~N}_{2} \mathrm{O}$ & $\mathrm{NO}_{\mathrm{x}}$ & $\mathrm{SO}_{\mathrm{x}}$ & $\mathrm{PM}_{10}$ & $\mathrm{PM}_{2.5}$ & VOC & $\mathrm{CO}$ \\
\hline \multicolumn{12}{|l|}{ NH (cont.) } \\
\hline NG & & $51.1 \%$ & 390.2 & 0.0076 & 0.0008 & 0.0405 & 0.0031 & 0.0042 & 0.0042 & 0.0062 & 0.9731 \\
\hline $\mathrm{CC}$ & $98.64 \%$ & $51.8 \%$ & 395.6 & 0.0077 & 0.0008 & 0.0296 & 0.0032 & 0.0008 & 0.0008 & 0.0016 & 0.0279 \\
\hline $\mathrm{CT}$ & $1.13 \%$ & $24.9 \%$ & 0.0 & 0.0000 & 0.0000 & 0.7392 & 0.0000 & 0.1715 & 0.1715 & 0.0897 & 3.0370 \\
\hline ICE & $0.23 \%$ & $30.2 \%$ & 0.0 & 0.0000 & 0.0000 & 1.2963 & 0.0000 & 0.6574 & 0.6574 & 1.5469 & 5.3208 \\
\hline \multicolumn{12}{|l|}{ Nuclear } \\
\hline Oil & & $26.2 \%$ & 1009.9 & 0.0442 & 0.0089 & 1.2228 & 6.6472 & 0.0667 & 0.0648 & 0.0319 & 0.2100 \\
\hline Boiler & $99.75 \%$ & $26.2 \%$ & 1008.4 & 0.0441 & 0.0088 & 1.2196 & 6.6618 & 0.0653 & 0.0646 & 0.0320 & 0.2104 \\
\hline CT & $0.25 \%$ & $16.7 \%$ & 1592.4 & 0.0691 & 0.0139 & 2.4938 & 0.9380 & 0.6031 & 0.1450 & 0.0019 & 0.0324 \\
\hline \multicolumn{12}{|c|}{ Renewable } \\
\hline WAT & $100.00 \%$ & & & & & & & & & & \\
\hline \multicolumn{12}{|l|}{ NJ } \\
\hline Biomass & & $20.2 \%$ & 1666.0 & 0.5980 & 0.0797 & 7.8853 & 22.4732 & 3.2300 & 2.2876 & 0.1457 & 5.1406 \\
\hline Boiler & $100.00 \%$ & $20.2 \%$ & 1666.0 & 0.5980 & 0.0797 & 7.8853 & 22.4732 & 3.2300 & 2.2876 & 0.1457 & 5.1406 \\
\hline Coal & & $32.0 \%$ & 1042.3 & 0.0122 & 0.0176 & 1.3711 & 4.4643 & 0.1487 & 0.1517 & 0.0155 & 0.1141 \\
\hline Boiler & $100.00 \%$ & $32.0 \%$ & 1042.3 & 0.0122 & 0.0176 & 1.3711 & 4.4643 & 0.1487 & 0.1517 & 0.0155 & 0.1141 \\
\hline NG & & $45.4 \%$ & 448.4 & 0.0088 & 0.0009 & 0.1216 & 0.0121 & 0.0094 & 0.0094 & 0.0150 & 0.1117 \\
\hline Boiler & $1.30 \%$ & $23.8 \%$ & 821.2 & 0.0204 & 0.0028 & 0.8577 & 0.4329 & 0.0561 & 0.0561 & 0.0406 & 0.6195 \\
\hline $\mathrm{CC}$ & $89.58 \%$ & $48.1 \%$ & 428.7 & 0.0083 & 0.0008 & 0.0743 & 0.0034 & 0.0009 & 0.0009 & 0.0018 & 0.0300 \\
\hline $\mathrm{CT}$ & $8.43 \%$ & $33.4 \%$ & 631.2 & 0.0130 & 0.0014 & 0.4586 & 0.0405 & 0.0339 & 0.0339 & 0.0108 & 0.4214 \\
\hline ICE & $0.70 \%$ & $21.0 \%$ & 72.3 & 0.0014 & 0.0001 & 0.7601 & 0.0021 & 0.7285 & 0.7285 & 1.7141 & 5.8961 \\
\hline \multicolumn{12}{|l|}{ Nuclear } \\
\hline Oil & & $21.4 \%$ & 1254.6 & 0.0539 & 0.0108 & 2.0617 & 0.6033 & 0.4743 & 0.2559 & 0.0137 & 0.0252 \\
\hline Boiler & $0.37 \%$ & $21.8 \%$ & 1226.6 & 0.0531 & 0.0106 & 1.9156 & 0.5668 & 0.4868 & 0.4868 & 0.0304 & 0.0251 \\
\hline $\mathrm{CT}$ & $99.63 \%$ & $21.4 \%$ & 1254.7 & 0.0539 & 0.0108 & 2.0622 & 0.6034 & 0.4742 & 0.2550 & 0.0137 & 0.0252 \\
\hline \multicolumn{12}{|c|}{ Renewable } \\
\hline WAT & $100.0 \%$ & & & & & & & & & & \\
\hline
\end{tabular}


TABLE 15 (Cont.)

\begin{tabular}{|c|c|c|c|c|c|c|c|c|c|c|c|}
\hline & Technology Share & Efficiency & $\mathrm{CO}_{2}$ & $\mathrm{CH}_{4}$ & $\mathrm{~N}_{2} \mathrm{O}$ & $\mathrm{NO}_{\mathrm{x}}$ & $\mathrm{SO}_{\mathrm{x}}$ & $\mathrm{PM}_{10}$ & $\mathrm{PM}_{2.5}$ & VOC & $\mathrm{CO}$ \\
\hline \multicolumn{12}{|l|}{ NM } \\
\hline Coal & & $36.5 \%$ & 935.9 & 0.0106 & 0.0159 & 2.2477 & 0.8737 & 0.0084 & 0.0041 & 0.0135 & 0.1126 \\
\hline Boiler & $100.00 \%$ & $36.5 \%$ & 935.9 & 0.0106 & 0.0159 & 2.2477 & 0.8737 & 0.0084 & 0.0041 & 0.0135 & 0.1126 \\
\hline NG & & $40.1 \%$ & 508.7 & 0.0100 & 0.0010 & 0.4474 & 0.0030 & 0.0176 & 0.0176 & 0.0131 & 0.2053 \\
\hline Boiler & $46.09 \%$ & $33.2 \%$ & 614.8 & 0.0121 & 0.0012 & 0.8830 & 0.0040 & 0.0361 & 0.0361 & 0.0262 & 0.3994 \\
\hline CC & $52.43 \%$ & $49.4 \%$ & 413.4 & 0.0081 & 0.0008 & 0.0625 & 0.0021 & 0.0008 & 0.0008 & 0.0017 & 0.0292 \\
\hline CT & $1.48 \%$ & $35.1 \%$ & 581.7 & 0.0114 & 0.0011 & 0.5181 & 0.0032 & 0.0323 & 0.0323 & 0.0103 & 0.4014 \\
\hline \multicolumn{12}{|c|}{ Renewable } \\
\hline WAT & $16.13 \%$ & & & & & & & & & & \\
\hline WND & $83.87 \%$ & & & & & & & & & & \\
\hline \multicolumn{12}{|l|}{ NV } \\
\hline Coal & & $31.0 \%$ & 1073.3 & 0.0122 & 0.0183 & 1.8151 & 1.0836 & 0.1064 & 0.1001 & 0.0134 & 0.1118 \\
\hline Boiler & $100.00 \%$ & $31.0 \%$ & 1073.3 & 0.0122 & 0.0183 & 1.8151 & 1.0836 & 0.1064 & 0.1001 & 0.0134 & 0.1118 \\
\hline NG & & $46.9 \%$ & 434.2 & 0.0085 & 0.0009 & 0.3483 & 0.0036 & 0.0065 & 0.0065 & 0.0117 & 0.0800 \\
\hline Boiler & $4.62 \%$ & $35.7 \%$ & 562.9 & 0.0112 & 0.0011 & 1.8379 & 0.0054 & 0.0335 & 0.0335 & 0.0243 & 0.3705 \\
\hline $\mathrm{CC}$ & $92.33 \%$ & $48.0 \%$ & 424.2 & 0.0083 & 0.0008 & 0.1563 & 0.0033 & 0.0009 & 0.0009 & 0.0018 & 0.0301 \\
\hline $\mathrm{CT}$ & $1.00 \%$ & $29.8 \%$ & 683.8 & 0.0134 & 0.0013 & 0.7111 & 0.0057 & 0.0381 & 0.0381 & 0.0121 & 0.4728 \\
\hline ICE & $2.05 \%$ & $42.5 \%$ & 472.3 & 0.0094 & 0.0009 & 5.4713 & 0.0139 & 0.1829 & 0.1829 & 0.4304 & 1.4805 \\
\hline \multicolumn{12}{|c|}{ Renewable } \\
\hline SUN & $0.08 \%$ & & & & & & & & & & \\
\hline GEO & $38.44 \%$ & & & & & & & & & & \\
\hline WAT & $61.47 \%$ & & & & & & & & & & \\
\hline \multicolumn{12}{|l|}{ NY } \\
\hline Biomass & & $22.6 \%$ & 1275.0 & 0.5340 & 0.0711 & 6.3128 & 17.2303 & 2.8332 & 2.0834 & 0.1301 & 4.5901 \\
\hline Boiler & $100.00 \%$ & $22.6 \%$ & 1275.0 & 0.5340 & 0.0711 & 6.3128 & 17.2303 & 2.8332 & 2.0834 & 0.1301 & 4.5901 \\
\hline Coal & & $35.0 \%$ & 958.7 & 0.0110 & 0.0163 & 1.0593 & 3.5782 & 0.1683 & 0.1281 & 0.0125 & 0.1433 \\
\hline Boiler & $100.00 \%$ & $35.0 \%$ & 958.7 & 0.0110 & 0.0163 & 1.0593 & 3.5782 & 0.1683 & 0.1281 & 0.0125 & 0.1433 \\
\hline
\end{tabular}


TABLE 15 (Cont.)

\begin{tabular}{|c|c|c|c|c|c|c|c|c|c|c|c|}
\hline & Technology Share & Efficiency & $\mathrm{CO}_{2}$ & $\mathrm{CH}_{4}$ & $\mathrm{~N}_{2} \mathrm{O}$ & $\mathrm{NO}_{\mathrm{x}}$ & $\mathrm{SO}_{\mathrm{x}}$ & $\mathrm{PM}_{10}$ & $\mathrm{PM}_{2.5}$ & VOC & $\mathrm{CO}$ \\
\hline \multicolumn{12}{|l|}{ NY (cont.) } \\
\hline NG & & $39.8 \%$ & 528.6 & 0.0113 & 0.0013 & 0.3206 & 0.1772 & 0.0207 & 0.0207 & 0.0238 & 0.2489 \\
\hline Boiler & $41.71 \%$ & $33.7 \%$ & 650.9 & 0.0149 & 0.0019 & 0.6321 & 0.4182 & 0.0309 & 0.0309 & 0.0258 & 0.3934 \\
\hline CC & $50.00 \%$ & $49.0 \%$ & 420.5 & 0.0082 & 0.0008 & 0.0327 & 0.0026 & 0.0008 & 0.0008 & 0.0017 & 0.0279 \\
\hline $\mathrm{CT}$ & $7.25 \%$ & $32.5 \%$ & 639.5 & 0.0137 & 0.0016 & 0.3746 & 0.0187 & 0.0349 & 0.0349 & 0.0111 & 0.4335 \\
\hline ICE & $1.03 \%$ & $32.8 \%$ & 39.5 & 0.0012 & 0.0002 & 1.3094 & 0.0047 & 0.4731 & 0.4731 & 1.1132 & 3.8290 \\
\hline \multicolumn{12}{|l|}{ Nuclear } \\
\hline Oil & & $34.7 \%$ & 697.9 & 0.0246 & 0.0045 & 0.8685 & 2.0566 & 0.0615 & 0.0513 & 0.0231 & 0.1519 \\
\hline Boiler & $96.05 \%$ & $35.0 \%$ & 686.6 & 0.0239 & 0.0043 & 0.7889 & 2.1308 & 0.0494 & 0.0491 & 0.0239 & 0.1573 \\
\hline $\mathrm{CT}$ & $3.90 \%$ & $27.7 \%$ & 973.8 & 0.0417 & 0.0084 & 2.7429 & 0.2553 & 0.3599 & 0.1075 & 0.0041 & 0.0194 \\
\hline ICE & $0.05 \%$ & $31.6 \%$ & 854.5 & 0.0366 & 0.0073 & 7.0962 & 0.2149 & 0.0118 & 0.0116 & 0.0134 & 0.0357 \\
\hline \multicolumn{12}{|c|}{ Renewable } \\
\hline WAT & $96.70 \%$ & & & & & & & & & & \\
\hline WND & $3.30 \%$ & & & & & & & & & & \\
\hline \multicolumn{12}{|l|}{$\mathbf{O H}$} \\
\hline Coal & & $36.0 \%$ & 928.8 & 0.0105 & 0.0158 & 1.6302 & 6.4398 & 0.3531 & 0.2025 & 0.0114 & 0.0970 \\
\hline Boiler & $100.00 \%$ & $36.0 \%$ & 928.8 & 0.0105 & 0.0158 & 1.6302 & 6.4398 & 0.3531 & 0.2025 & 0.0114 & 0.0970 \\
\hline NG & & $40.9 \%$ & 497.8 & 0.0099 & 0.0010 & 0.1521 & 0.0034 & 0.0104 & 0.0104 & 0.0047 & 0.1435 \\
\hline Boiler & $0.29 \%$ & $27.2 \%$ & 0.0 & 0.0000 & 0.0000 & 2.8728 & 0.0000 & 0.0873 & 0.0873 & 0.0632 & 0.9654 \\
\hline CC & $76.47 \%$ & $47.8 \%$ & 427.3 & 0.0084 & 0.0008 & 0.0851 & 0.0022 & 0.0009 & 0.0009 & 0.0018 & 0.0302 \\
\hline $\mathrm{CT}$ & $23.21 \%$ & $27.9 \%$ & 735.9 & 0.0150 & 0.0016 & 0.3352 & 0.0076 & 0.0406 & 0.0406 & 0.0129 & 0.5045 \\
\hline ICE & $0.03 \%$ & $36.2 \%$ & 575.7 & 0.0131 & 0.0016 & 3.4211 & 0.0466 & 0.2150 & 0.2150 & 0.5058 & 1.7399 \\
\hline \multicolumn{12}{|l|}{ Nuclear } \\
\hline Oil & & $17.6 \%$ & 1515.0 & 0.0640 & 0.0127 & 7.2056 & 0.6694 & 0.5582 & 0.1342 & 0.0040 & 0.0308 \\
\hline CT & $54.53 \%$ & $12.6 \%$ & 2111.9 & 0.0888 & 0.0177 & 3.2477 & 0.9333 & 0.7906 & 0.1898 & 0.0053 & 0.0425 \\
\hline ICE & $45.47 \%$ & $33.8 \%$ & 799.3 & 0.0342 & 0.0069 & 11.9515 & 0.3529 & 0.2795 & 0.0675 & 0.0026 & 0.0168 \\
\hline
\end{tabular}


TABLE 15 (Cont.)

\begin{tabular}{|c|c|c|c|c|c|c|c|c|c|c|c|}
\hline & Technology Share & Efficiency & $\mathrm{CO}_{2}$ & $\mathrm{CH}_{4}$ & $\mathrm{~N}_{2} \mathrm{O}$ & $\mathrm{NO}_{\mathrm{x}}$ & $\mathrm{SO}_{\mathrm{x}}$ & $\mathrm{PM}_{10}$ & $\mathrm{PM}_{2.5}$ & VOC & $\mathrm{CO}$ \\
\hline \multicolumn{12}{|l|}{$\mathbf{O H}$ (cont.) } \\
\hline \multicolumn{12}{|c|}{ Renewable } \\
\hline WAT & $96.53 \%$ & & & & & & & & & & \\
\hline WND & $3.47 \%$ & & & & & & & & & & \\
\hline \multicolumn{12}{|l|}{ OK } \\
\hline Coal & & $33.4 \%$ & 1013.5 & 0.0116 & 0.0172 & 1.6136 & 2.4763 & 0.0553 & 0.0378 & 0.0147 & 0.1229 \\
\hline Boiler & $100.00 \%$ & $33.4 \%$ & 1013.5 & 0.0116 & 0.0172 & 1.6136 & 2.4763 & 0.0553 & 0.0378 & 0.0147 & 0.1229 \\
\hline NG & & $42.0 \%$ & 485.9 & 0.0095 & 0.0010 & 0.6345 & 0.0336 & 0.0081 & 0.0081 & 0.0100 & 0.1559 \\
\hline Boiler & $33.35 \%$ & $32.9 \%$ & 622.5 & 0.0122 & 0.0012 & 1.3993 & 0.0943 & 0.0222 & 0.0222 & 0.0264 & 0.4029 \\
\hline $\mathrm{CC}$ & $66.18 \%$ & $49.0 \%$ & 416.2 & 0.0082 & 0.0008 & 0.2512 & 0.0032 & 0.0008 & 0.0008 & 0.0017 & 0.0295 \\
\hline $\mathrm{CT}$ & $0.47 \%$ & $33.5 \%$ & 608.1 & 0.0119 & 0.0012 & 0.2866 & 0.0048 & 0.0338 & 0.0338 & 0.0108 & 0.4200 \\
\hline Oil & & $23.8 \%$ & 1136.2 & 0.0486 & 0.0098 & 16.9882 & 1.4246 & 0.1588 & 0.0456 & 0.0124 & 0.0381 \\
\hline ICE & $100.00 \%$ & $23.8 \%$ & 1136.2 & 0.0486 & 0.0098 & 16.9882 & 1.4246 & 0.1588 & 0.0456 & 0.0124 & 0.0381 \\
\hline \multicolumn{12}{|c|}{ Renewable } \\
\hline WAT & $61.06 \%$ & & & & & & & & & & \\
\hline WND & $38.94 \%$ & & & & & & & & & & \\
\hline \multicolumn{12}{|l|}{ OR } \\
\hline Coal & & $34.0 \%$ & 1002.6 & 0.0114 & 0.0171 & 2.2198 & 2.9240 & 0.0654 & 0.0341 & 0.0145 & 0.1206 \\
\hline Boiler & $100.00 \%$ & $34.0 \%$ & 1002.6 & 0.0114 & 0.0171 & 2.2198 & 2.9240 & 0.0654 & 0.0341 & 0.0145 & 0.1206 \\
\hline NG & & $50.7 \%$ & 399.6 & 0.0079 & 0.0008 & 0.1211 & 0.0037 & 0.0013 & 0.0013 & 0.0019 & 0.0337 \\
\hline Boiler & $0.38 \%$ & $37.6 \%$ & 0.0 & 0.0000 & 0.0000 & 5.2006 & 0.0000 & 0.0687 & 0.0687 & 0.0497 & 0.7591 \\
\hline CC & $98.92 \%$ & $50.9 \%$ & 399.9 & 0.0079 & 0.0008 & 0.1012 & 0.0037 & 0.0008 & 0.0008 & 0.0017 & 0.0284 \\
\hline $\mathrm{CT}$ & $0.70 \%$ & $36.0 \%$ & 566.2 & 0.0111 & 0.0011 & 0.1562 & 0.0032 & 0.0315 & 0.0315 & 0.0100 & 0.3908 \\
\hline \multicolumn{12}{|c|}{ Renewable } \\
\hline WAT & $96.42 \%$ & & & & & & & & & & \\
\hline WND & $3.58 \%$ & & & & & & & & & & \\
\hline
\end{tabular}


TABLE 15 (Cont.)

\begin{tabular}{|c|c|c|c|c|c|c|c|c|c|c|c|}
\hline & Technology Share & Efficiency & $\mathrm{CO}_{2}$ & $\mathrm{CH}_{4}$ & $\mathrm{~N}_{2} \mathrm{O}$ & $\mathrm{NO}_{\mathrm{x}}$ & $\mathrm{SO}_{\mathrm{x}}$ & $\mathrm{PM}_{10}$ & $\mathrm{PM}_{2.5}$ & VOC & $\mathrm{CO}$ \\
\hline \multicolumn{12}{|l|}{ PA } \\
\hline Biomass & & $21.4 \%$ & 1587.0 & 0.5613 & 0.0748 & 7.4879 & 21.3252 & 3.0468 & 2.1578 & 0.1374 & 4.8490 \\
\hline Boiler & $100.00 \%$ & $21.4 \%$ & 1587.0 & 0.5613 & 0.0748 & 7.4879 & 21.3252 & 3.0468 & 2.1578 & 0.1374 & 4.8490 \\
\hline Coal & & $36.6 \%$ & 906.6 & 0.0104 & 0.0153 & 1.3913 & 7.4888 & 0.1992 & 0.1672 & 0.0107 & 0.0838 \\
\hline Boiler & $100.00 \%$ & $36.6 \%$ & 906.6 & 0.0104 & 0.0153 & 1.3913 & 7.4888 & 0.1992 & 0.1672 & 0.0107 & 0.0838 \\
\hline NG & & $48.0 \%$ & 413.7 & 0.0081 & 0.0008 & 0.0691 & 0.0032 & 0.0086 & 0.0086 & 0.0162 & 0.1033 \\
\hline Boiler & $0.30 \%$ & $28.2 \%$ & 0.0 & 0.0000 & 0.0000 & 1.1487 & 0.0000 & 0.0866 & 0.0866 & 0.0627 & 0.9573 \\
\hline $\mathrm{CC}$ & $95.19 \%$ & $49.3 \%$ & 414.6 & 0.0081 & 0.0008 & 0.0436 & 0.0031 & 0.0008 & 0.0008 & 0.0017 & 0.0293 \\
\hline CT & $3.47 \%$ & $32.7 \%$ & 519.0 & 0.0102 & 0.0010 & 0.3534 & 0.0031 & 0.0507 & 0.0507 & 0.0206 & 0.7448 \\
\hline ICE & $1.04 \%$ & $28.8 \%$ & 98.2 & 0.0023 & 0.0003 & 1.1422 & 0.0143 & 0.5545 & 0.5545 & 1.3048 & 4.4881 \\
\hline \multicolumn{12}{|l|}{ Nuclear } \\
\hline Oil & & $27.7 \%$ & 1024.5 & 0.0417 & 0.0084 & 1.4178 & 1.9103 & 0.3625 & 0.1893 & 0.0170 & 0.1138 \\
\hline Boiler & $58.78 \%$ & $31.0 \%$ & 956.6 & 0.0373 & 0.0075 & 1.1966 & 2.5659 & 0.3263 & 0.2523 & 0.0271 & 0.1780 \\
\hline $\mathrm{CT}$ & $41.22 \%$ & $24.1 \%$ & 1121.4 & 0.0480 & 0.0096 & 1.7332 & 0.9752 & 0.4142 & 0.0994 & 0.0028 & 0.0223 \\
\hline \multicolumn{12}{|c|}{ Renewable } \\
\hline WAT & $76.30 \%$ & & & & & & & & & & \\
\hline WND & $23.70 \%$ & & & & & & & & & & \\
\hline \multicolumn{12}{|l|}{ RI } \\
\hline NG & & $47.8 \%$ & 410.6 & 0.0081 & 0.0008 & 0.0915 & 0.0046 & 0.0126 & 0.0126 & 0.0295 & 0.1247 \\
\hline CC & $97.77 \%$ & $48.4 \%$ & 419.9 & 0.0083 & 0.0008 & 0.0644 & 0.0047 & 0.0009 & 0.0009 & 0.0018 & 0.0298 \\
\hline ICE & $2.23 \%$ & $30.5 \%$ & 0.0 & 0.0000 & 0.0000 & 1.2809 & 0.0000 & 0.5294 & 0.5294 & 1.2456 & 4.2845 \\
\hline Oil & & $31.5 \%$ & 856.7 & 0.0367 & 0.0074 & 7.1147 & 1.0806 & 0.3165 & 0.0760 & 0.0021 & 0.0170 \\
\hline ICE & $100.00 \%$ & $31.5 \%$ & 856.7 & 0.0367 & 0.0074 & 7.1147 & 1.0806 & 0.3165 & 0.0760 & 0.0021 & 0.0170 \\
\hline \multicolumn{12}{|c|}{ Renewable } \\
\hline WAT & $100.00 \%$ & & & & & & & & & & \\
\hline
\end{tabular}


TABLE 15 (Cont.)

\begin{tabular}{|c|c|c|c|c|c|c|c|c|c|c|c|}
\hline & Technology Share & Efficiency & $\mathrm{CO}_{2}$ & $\mathrm{CH}_{4}$ & $\mathrm{~N}_{2} \mathrm{O}$ & $\mathrm{NO}_{\mathrm{x}}$ & $\mathrm{SO}_{\mathrm{x}}$ & $\mathrm{PM}_{10}$ & $\mathrm{PM}_{2.5}$ & VOC & $\mathrm{CO}$ \\
\hline \multicolumn{12}{|l|}{ SC } \\
\hline Coal & & $35.0 \%$ & 950.6 & 0.0108 & 0.0161 & 0.9534 & 3.5053 & 0.2265 & 0.1428 & 0.0097 & 0.0808 \\
\hline Boiler & $100.00 \%$ & $35.0 \%$ & 950.6 & 0.0108 & 0.0161 & 0.9534 & 3.5053 & 0.2265 & 0.1428 & 0.0097 & 0.0808 \\
\hline NG & & $42.3 \%$ & 474.8 & 0.0093 & 0.0009 & 0.1358 & 0.0043 & 0.0184 & 0.0184 & 0.0105 & 0.2329 \\
\hline Boiler & $0.71 \%$ & $31.1 \%$ & 0.0 & 0.0000 & 0.0000 & 2.5167 & 0.0000 & 0.0840 & 0.0840 & 0.0608 & 0.9287 \\
\hline CC & $48.88 \%$ & $49.5 \%$ & 412.7 & 0.0081 & 0.0008 & 0.0423 & 0.0022 & 0.0008 & 0.0008 & 0.0017 & 0.0292 \\
\hline CT & $50.04 \%$ & $37.2 \%$ & 545.6 & 0.0106 & 0.0011 & 0.1783 & 0.0065 & 0.0313 & 0.0313 & 0.0102 & 0.3955 \\
\hline ICE & $0.37 \%$ & $36.0 \%$ & 0.0 & 0.0000 & 0.0000 & 2.1724 & 0.0000 & 0.4705 & 0.4705 & 1.1070 & 3.8076 \\
\hline \multicolumn{12}{|l|}{ Nuclear } \\
\hline Oil & & $16.1 \%$ & 1675.8 & 0.0717 & 0.0144 & 10.5608 & 4.3579 & 0.6190 & 0.1486 & 0.0041 & 0.0333 \\
\hline $\mathrm{CT}$ & $28.54 \%$ & $7.1 \%$ & 3788.8 & 0.1622 & 0.0325 & 5.8559 & 9.8296 & 1.3995 & 0.3359 & 0.0093 & 0.0752 \\
\hline ICE & $71.46 \%$ & $32.4 \%$ & 831.9 & 0.0356 & 0.0071 & 12.4400 & 2.1725 & 0.3073 & 0.0738 & 0.0021 & 0.0165 \\
\hline \multicolumn{12}{|c|}{ Renewable } \\
\hline WAT & $100.00 \%$ & & & & & & & & & & \\
\hline \multicolumn{12}{|l|}{ SD } \\
\hline Coal & & $31.7 \%$ & 1078.3 & 0.0122 & 0.0183 & 3.6718 & 3.3057 & 0.3085 & 0.1235 & 0.0155 & 0.1295 \\
\hline Boiler & $100.00 \%$ & $31.7 \%$ & 1078.3 & 0.0122 & 0.0183 & 3.6718 & 3.3057 & 0.3085 & 0.1235 & 0.0155 & 0.1295 \\
\hline NG & & $29.4 \%$ & 734.4 & 0.0136 & 0.0014 & 0.4557 & 0.0179 & 0.0393 & 0.0393 & 0.0143 & 0.4848 \\
\hline $\mathrm{CT}$ & $99.85 \%$ & $29.4 \%$ & 732.9 & 0.0136 & 0.0014 & 0.4235 & 0.0167 & 0.0385 & 0.0385 & 0.0122 & 0.4782 \\
\hline ICE & $0.15 \%$ & $13.0 \%$ & 1708.9 & 0.0478 & 0.0074 & 21.8124 & 0.7860 & 0.5962 & 0.5962 & 1.4029 & 4.8255 \\
\hline Oil & & $25.0 \%$ & 1080.6 & 0.0463 & 0.0093 & 2.7801 & 1.3464 & 0.3951 & 0.0950 & 0.0028 & 0.0217 \\
\hline СT & $93.25 \%$ & $24.6 \%$ & 1099.2 & 0.0471 & 0.0094 & 2.0899 & 1.3724 & 0.4060 & 0.0975 & 0.0027 & 0.0218 \\
\hline ICE & $6.75 \%$ & $32.8 \%$ & 823.4 & 0.0352 & 0.0071 & 12.3116 & 0.9863 & 0.2439 & 0.0603 & 0.0042 & 0.0199 \\
\hline
\end{tabular}

\section{Renewable}

WAT $\quad 94.21 \%$

WND $5.79 \%$ 
TABLE 15 (Cont.)

\begin{tabular}{|c|c|c|c|c|c|c|c|c|c|c|c|}
\hline & Technology Share & Efficiency & $\mathrm{CO}_{2}$ & $\mathrm{CH}_{4}$ & $\mathrm{~N}_{2} \mathrm{O}$ & $\mathrm{NO}_{\mathrm{x}}$ & $\mathrm{SO}_{\mathrm{x}}$ & $\mathrm{PM}_{10}$ & $\mathrm{PM}_{2.5}$ & VOC & $\mathrm{CO}$ \\
\hline \multicolumn{12}{|l|}{$\mathbf{T N}$} \\
\hline Coal & & $35.1 \%$ & 955.3 & 0.0109 & 0.0162 & 1.4948 & 3.0442 & 0.1944 & 0.1542 & 0.0124 & 0.1033 \\
\hline Boiler & $100.00 \%$ & $35.1 \%$ & 955.3 & 0.0109 & 0.0162 & 1.4948 & 3.0442 & 0.1944 & 0.1542 & 0.0124 & 0.1033 \\
\hline NG & & $30.9 \%$ & 625.8 & 0.0124 & 0.0012 & 0.3407 & 0.0070 & 0.0577 & 0.0577 & 0.0642 & 0.6192 \\
\hline CT & $95.76 \%$ & $30.9 \%$ & 653.5 & 0.0130 & 0.0013 & 0.2438 & 0.0074 & 0.0367 & 0.0367 & 0.0117 & 0.4561 \\
\hline ICE & $4.24 \%$ & $30.9 \%$ & 0.0 & 0.0000 & 0.0000 & 2.5275 & 0.0000 & 0.5314 & 0.5314 & 1.2504 & 4.3011 \\
\hline \multicolumn{12}{|l|}{ Nuclear } \\
\hline Oil & & $37.8 \%$ & 713.8 & 0.0306 & 0.0061 & 10.6738 & 0.8945 & 0.2637 & 0.0633 & 0.0018 & 0.0142 \\
\hline ICE & $100.00 \%$ & $37.8 \%$ & 713.8 & 0.0306 & 0.0061 & 10.6738 & 0.8945 & 0.2637 & 0.0633 & 0.0018 & 0.0142 \\
\hline \multicolumn{12}{|c|}{ Renewable } \\
\hline WAT & $98.83 \%$ & & & & & & & & & & \\
\hline WND & $1.17 \%$ & & & & & & & & & & \\
\hline \multicolumn{12}{|l|}{ TX } \\
\hline Biomass & & $37.7 \%$ & 0.0 & 0.0342 & 0.0069 & 6.6320 & 0.0539 & 1.8466 & 1.3078 & 0.0833 & 2.9389 \\
\hline Boiler & $100.00 \%$ & $37.7 \%$ & 0.0 & 0.0342 & 0.0069 & 6.6320 & 0.0539 & 1.8466 & 1.3078 & 0.0833 & 2.9389 \\
\hline Coal & & $34.3 \%$ & 1029.6 & 0.0114 & 0.0170 & 0.7637 & 3.0292 & 0.0988 & 0.0953 & 0.0173 & 0.2277 \\
\hline Boiler & $100.00 \%$ & $34.3 \%$ & 1029.6 & 0.0114 & 0.0170 & 0.7637 & 3.0292 & 0.0988 & 0.0953 & 0.0173 & 0.2277 \\
\hline NG & & $44.2 \%$ & 459.9 & 0.0090 & 0.0009 & 0.2386 & 0.0031 & 0.0110 & 0.0110 & 0.0105 & 0.1340 \\
\hline Boiler & $22.93 \%$ & $32.8 \%$ & 620.5 & 0.0122 & 0.0012 & 0.6319 & 0.0059 & 0.0383 & 0.0383 & 0.0277 & 0.4233 \\
\hline $\mathrm{CC}$ & $75.70 \%$ & $50.0 \%$ & 408.6 & 0.0080 & 0.0008 & 0.1166 & 0.0022 & 0.0008 & 0.0008 & 0.0017 & 0.0289 \\
\hline CT & $1.13 \%$ & $28.7 \%$ & 710.0 & 0.0139 & 0.0014 & 0.2055 & 0.0042 & 0.0395 & 0.0395 & 0.0126 & 0.4902 \\
\hline ICE & $0.24 \%$ & $31.3 \%$ & 112.0 & 0.0022 & 0.0002 & 1.2923 & 0.0035 & 0.4896 & 0.4896 & 1.1520 & 3.9625 \\
\hline \multicolumn{12}{|l|}{ Nuclear } \\
\hline \multicolumn{12}{|c|}{ Renewable } \\
\hline WAT & $15.10 \%$ & & & & & & & & & & \\
\hline WH & $2.22 \%$ & & & & & & & & & & \\
\hline WND & $82.69 \%$ & & & & & & & & & & \\
\hline
\end{tabular}


TABLE 15 (Cont.)

\begin{tabular}{|c|c|c|c|c|c|c|c|c|c|c|c|}
\hline & Technology Share & Efficiency & $\mathrm{CO}_{2}$ & $\mathrm{CH}_{4}$ & $\mathrm{~N}_{2} \mathrm{O}$ & $\mathrm{NO}_{\mathrm{x}}$ & $\mathrm{SO}_{\mathrm{x}}$ & $\mathrm{PM}_{10}$ & $\mathrm{PM}_{2.5}$ & VOC & $\mathrm{CO}$ \\
\hline \multicolumn{12}{|l|}{ UT } \\
\hline Coal & & $33.7 \%$ & 987.6 & 0.0112 & 0.0168 & 1.8269 & 0.6535 & 0.3258 & 0.1115 & 0.0123 & 0.1026 \\
\hline Boiler & $100.00 \%$ & $33.7 \%$ & 987.6 & 0.0112 & 0.0168 & 1.8269 & 0.6535 & 0.3258 & 0.1115 & 0.0123 & 0.1026 \\
\hline NG & & $46.6 \%$ & 438.2 & 0.0086 & 0.0009 & 0.1452 & 0.0035 & 0.0116 & 0.0116 & 0.0107 & 0.1398 \\
\hline Boiler & $11.08 \%$ & $29.5 \%$ & 692.7 & 0.0136 & 0.0014 & 0.3419 & 0.0035 & 0.0407 & 0.0407 & 0.0294 & 0.4495 \\
\hline $\mathrm{CC}$ & $75.05 \%$ & $55.3 \%$ & 368.8 & 0.0072 & 0.0007 & 0.0303 & 0.0019 & 0.0008 & 0.0008 & 0.0015 & 0.0245 \\
\hline $\mathrm{CT}$ & $13.08 \%$ & $33.7 \%$ & 603.9 & 0.0119 & 0.0012 & 0.1616 & 0.0038 & 0.0336 & 0.0336 & 0.0107 & 0.4172 \\
\hline ICE & $0.78 \%$ & $28.8 \%$ & 727.9 & 0.0170 & 0.0022 & 8.1533 & 0.1609 & 0.2697 & 0.2697 & 0.6346 & 2.1830 \\
\hline Oil & & $36.0 \%$ & 749.5 & 0.0321 & 0.0064 & 11.2078 & 0.9963 & 0.2769 & 0.0665 & 0.0018 & 0.0149 \\
\hline ICE & $100.00 \%$ & $36.0 \%$ & 749.5 & 0.0321 & 0.0064 & 11.2078 & 0.9963 & 0.2769 & 0.0665 & 0.0018 & 0.0149 \\
\hline \multicolumn{12}{|c|}{ Renewable } \\
\hline GEO & $23.33 \%$ & & & & & & & & & & \\
\hline WAT & $76.67 \%$ & & & & & & & & & & \\
\hline \multicolumn{12}{|l|}{ VA } \\
\hline Biomass & & $23.8 \%$ & 1016.1 & 0.5065 & 0.0675 & 5.3845 & 13.7280 & 2.6561 & 2.0173 & 0.1238 & 4.3710 \\
\hline Boiler & $100.00 \%$ & $23.8 \%$ & 1016.1 & 0.5065 & 0.0675 & 5.3845 & 13.7280 & 2.6561 & 2.0173 & 0.1238 & 4.3710 \\
\hline Coal & & $35.8 \%$ & 914.9 & 0.0112 & 0.0152 & 1.3939 & 4.8710 & 0.2048 & 0.1804 & 0.0116 & 0.0966 \\
\hline Boiler & $100.00 \%$ & $35.8 \%$ & 914.9 & 0.0112 & 0.0152 & 1.3939 & 4.8710 & 0.2048 & 0.1804 & 0.0116 & 0.0966 \\
\hline NG & & $43.3 \%$ & 479.9 & 0.0109 & 0.0013 & 0.2238 & 0.2118 & 0.0131 & 0.0131 & 0.0180 & 0.1543 \\
\hline Boiler & $0.23 \%$ & $28.8 \%$ & 0.0 & 0.0000 & 0.0000 & 1.3585 & 0.0000 & 0.1482 & 0.1482 & 0.0776 & 2.6258 \\
\hline CC & $81.04 \%$ & $46.4 \%$ & 454.1 & 0.0104 & 0.0013 & 0.1673 & 0.2500 & 0.0009 & 0.0009 & 0.0018 & 0.0311 \\
\hline $\mathrm{CT}$ & $17.42 \%$ & $33.4 \%$ & 634.8 & 0.0127 & 0.0014 & 0.3606 & 0.0486 & 0.0339 & 0.0339 & 0.0108 & 0.4214 \\
\hline ICE & $1.31 \%$ & $37.7 \%$ & 95.7 & 0.0198 & 0.0028 & 1.6956 & 0.0559 & 0.4682 & 0.4682 & 1.1017 & 3.7894 \\
\hline \multicolumn{12}{|l|}{ Nuclear } \\
\hline Oil & & $32.9 \%$ & 856.5 & 0.0495 & 0.0089 & 2.3765 & 0.3421 & 0.2589 & 0.0634 & 0.0032 & 0.0188 \\
\hline CT & $72.91 \%$ & $31.9 \%$ & 896.6 & 0.0363 & 0.0073 & 0.9521 & 0.2916 & 0.3129 & 0.0751 & 0.0021 & 0.0168 \\
\hline ICE & $27.09 \%$ & $36.1 \%$ & 748.6 & 0.0851 & 0.0131 & 6.2104 & 0.4778 & 0.1135 & 0.0318 & 0.0063 & 0.0243 \\
\hline
\end{tabular}


TABLE 15 (Cont.)

\begin{tabular}{|c|c|c|c|c|c|c|c|c|c|c|c|}
\hline & Technology Share & Efficiency & $\mathrm{CO}_{2}$ & $\mathrm{CH}_{4}$ & $\mathrm{~N}_{2} \mathrm{O}$ & $\mathrm{NO}_{\mathrm{x}}$ & $\mathrm{SO}_{\mathrm{x}}$ & $\mathrm{PM}_{10}$ & $\mathrm{PM}_{2.5}$ & VOC & $\mathrm{CO}$ \\
\hline \multicolumn{12}{|l|}{ VA (cont.) } \\
\hline \multicolumn{12}{|c|}{ Renewable } \\
\hline WAT & $100.00 \%$ & & & & & & & & & & \\
\hline \multicolumn{12}{|l|}{ VT } \\
\hline Biomass & & $24.0 \%$ & 5.8 & 0.5028 & 0.0670 & 1.2047 & 0.0180 & 0.0236 & 1.9234 & 0.1225 & 4.3223 \\
\hline Boiler & $100.00 \%$ & $24.0 \%$ & 5.8 & 0.5028 & 0.0670 & 1.2047 & 0.0180 & 0.0236 & 1.9234 & 0.1225 & 4.3223 \\
\hline \multicolumn{12}{|l|}{ Nuclear } \\
\hline Oil & & $23.8 \%$ & 1127.5 & 0.0486 & 0.0098 & 1.7551 & 0.7910 & 0.4272 & 0.3263 & 0.0199 & 0.0228 \\
\hline CT & $100.00 \%$ & $23.8 \%$ & 1127.5 & 0.0486 & 0.0098 & 1.7551 & 0.7910 & 0.4272 & 0.3263 & 0.0199 & 0.0228 \\
\hline
\end{tabular}

ติ

$\begin{array}{cc}\begin{array}{c}\text { Biomass } \\ \text { Boiler } \\ \text { Coal } \\ \text { Boiler }\end{array} & 100.00 \% \\ \text { NG } & 100.00 \% \\ \text { CC } & 97.44 \% \\ \text { CT } & 0.49 \% \\ \text { ICE } & 2.07 \% \\ \text { Nuclear } & \\ \text { Oil } & \\ \text { ICE } & 100.00 \% \\ \text { Renewable } & \\ \text { WAT } & 97.00 \% \\ \text { WND } & 3.00 \%\end{array}$

$\begin{array}{llllllllll}19.2 \% & 1689.4 & 0.6277 & 0.0836 & 7.9959 & 22.7886 & 3.3902 & 2.4010 & 0.1529 & 5.3956 \\ 19.2 \% & 1689.4 & 0.6277 & 0.0836 & 7.9959 & 22.7886 & 3.3902 & 2.4010 & 0.1529 & 5.3956 \\ 31.5 \% & 1069.7 & 0.0123 & 0.0179 & 1.2452 & 0.2177 & 0.0070 & 0.0495 & 0.0157 & 0.1305 \\ 31.5 \% & 1069.7 & 0.0123 & 0.0179 & 1.2452 & 0.2177 & 0.0070 & 0.0495 & 0.0157 & 0.1305 \\ 51.2 \% & 390.3 & 0.0077 & 0.0008 & 0.1438 & 0.0047 & 0.0075 & 0.0075 & 0.0170 & 0.0821 \\ 51.7 \% & 394.6 & 0.0077 & 0.0008 & 0.0368 & 0.0044 & 0.0008 & 0.0008 & 0.0017 & 0.0279 \\ 28.8 \% & 712.2 & 0.0152 & 0.0017 & 1.6350 & 0.0773 & 0.0393 & 0.0393 & 0.0125 & 0.4885 \\ 40.4 \% & 112.0 & 0.0022 & 0.0002 & 4.8257 & 0.0033 & 0.3137 & 0.3137 & 0.7382 & 2.5393 \\ & & & & & & & & & \\ 32.3 \% & 836.3 & 0.0358 & 0.0072 & 12.5050 & 1.1062 & 0.0132 & 0.0116 & 0.0129 & 0.0342 \\ 32.3 \% & 836.3 & 0.0358 & 0.0072 & 12.5050 & 1.1062 & 0.0132 & 0.0116 & 0.0129 & 0.0342\end{array}$


TABLE 15 (Cont.)

\begin{tabular}{|c|c|c|c|c|c|c|c|c|c|c|c|}
\hline & Technology Share & Efficiency & $\mathrm{CO}_{2}$ & $\mathrm{CH}_{4}$ & $\mathrm{~N}_{2} \mathrm{O}$ & $\mathrm{NO}_{\mathrm{x}}$ & $\mathrm{SO}_{\mathrm{x}}$ & $\mathrm{PM}_{10}$ & $\mathrm{PM}_{2.5}$ & VOC & $\mathrm{CO}$ \\
\hline \multicolumn{12}{|l|}{ WI } \\
\hline Biomass & & $24.3 \%$ & 810.2 & 0.3371 & 0.0520 & 3.8158 & 3.3778 & 0.4995 & 0.4690 & 0.1211 & 4.2748 \\
\hline Boiler & $100.00 \%$ & $24.3 \%$ & 810.2 & 0.3371 & 0.0520 & 3.8158 & 3.3778 & 0.4995 & 0.4690 & 0.1211 & 4.2748 \\
\hline Coal & & $32.0 \%$ & 1061.4 & 0.0121 & 0.0180 & 1.1344 & 3.0659 & 0.0475 & 0.0338 & 0.0152 & 0.1264 \\
\hline Boiler & $100.00 \%$ & $32.0 \%$ & 1061.4 & 0.0121 & 0.0180 & 1.1344 & 3.0659 & 0.0475 & 0.0338 & 0.0152 & 0.1264 \\
\hline NG & & $41.8 \%$ & 437.5 & 0.0087 & 0.0009 & 0.5328 & 0.0068 & 0.0374 & 0.0374 & 0.0650 & 0.3978 \\
\hline Boiler & $0.97 \%$ & $25.1 \%$ & 813.6 & 0.0163 & 0.0017 & 2.3407 & 0.0370 & 0.0038 & 0.0038 & 0.0346 & 0.5287 \\
\hline $\mathrm{CC}$ & $73.89 \%$ & $51.1 \%$ & 399.6 & 0.0078 & 0.0008 & 0.0473 & 0.0021 & 0.0008 & 0.0008 & 0.0017 & 0.0283 \\
\hline CT & $20.33 \%$ & $27.1 \%$ & 660.1 & 0.0138 & 0.0015 & 0.8157 & 0.0238 & 0.0578 & 0.0578 & 0.0229 & 0.8341 \\
\hline ICE & $4.80 \%$ & $30.4 \%$ & 1.5 & 0.0000 & 0.0000 & 6.4408 & 0.0003 & 0.5204 & 0.5204 & 1.2245 & 4.2120 \\
\hline \multicolumn{12}{|l|}{ Nuclear } \\
\hline Oil & & $24.4 \%$ & 1104.8 & 0.0473 & 0.0095 & 10.4601 & 0.4848 & 0.2423 & 0.0638 & 0.0093 & 0.0364 \\
\hline $\mathrm{CT}$ & $38.05 \%$ & $22.1 \%$ & 1220.1 & 0.0522 & 0.0105 & 2.3198 & 0.5348 & 0.4507 & 0.1082 & 0.0030 & 0.0242 \\
\hline ICE & $61.95 \%$ & $26.1 \%$ & 1033.9 & 0.0443 & 0.0089 & 15.4600 & 0.4541 & 0.1144 & 0.0366 & 0.0132 & 0.0439 \\
\hline \multicolumn{12}{|c|}{ Renewable } \\
\hline WAT & $92.53 \%$ & & & & & & & & & & \\
\hline WND & $7.47 \%$ & & & & & & & & & & \\
\hline \multicolumn{12}{|l|}{ WV } \\
\hline Coal & & $36.6 \%$ & 909.7 & 0.0103 & 0.0155 & 1.5153 & 3.7784 & 0.2204 & 0.1737 & 0.0117 & 0.1227 \\
\hline Boiler & $100.00 \%$ & $36.6 \%$ & 909.7 & 0.0103 & 0.0155 & 1.5153 & 3.7784 & 0.2204 & 0.1737 & 0.0117 & 0.1227 \\
\hline NG & & $32.5 \%$ & 625.4 & 0.0127 & 0.0013 & 0.2911 & 0.0146 & 0.0349 & 0.0349 & 0.0111 & 0.4338 \\
\hline CT & $100.00 \%$ & $32.5 \%$ & 625.4 & 0.0127 & 0.0013 & 0.2911 & 0.0146 & 0.0349 & 0.0349 & 0.0111 & 0.4338 \\
\hline \multicolumn{12}{|c|}{ Renewable } \\
\hline WAT & $88.21 \%$ & & & & & & & & & & \\
\hline WND & $11.79 \%$ & & & & & & & & & & \\
\hline
\end{tabular}


TABLE 15 (Cont.)

\begin{tabular}{|c|c|c|c|c|c|c|c|c|c|c|c|}
\hline & Technology Share & Efficiency & $\mathrm{CO}_{2}$ & $\mathrm{CH}_{4}$ & $\mathrm{~N}_{2} \mathrm{O}$ & $\mathrm{NO}_{\mathrm{x}}$ & $\mathrm{SO}_{\mathrm{x}}$ & $\mathrm{PM}_{10}$ & $\mathrm{PM}_{2.5}$ & VOC & $\mathrm{CO}$ \\
\hline \multicolumn{12}{|l|}{ WY } \\
\hline Coal & & $32.0 \%$ & 1066.5 & 0.0121 & 0.0181 & 1.7013 & 1.7864 & 1.2442 & 0.3645 & 0.0154 & 0.1283 \\
\hline Boiler & $100.00 \%$ & $32.0 \%$ & 1066.5 & 0.0121 & 0.0181 & 1.7013 & 1.7864 & 1.2442 & 0.3645 & 0.0154 & 0.1283 \\
\hline NG & & $30.3 \%$ & 665.4 & 0.0132 & 0.0013 & 1.3653 & 0.0176 & 0.0375 & 0.0375 & 0.0119 & 0.4654 \\
\hline CT & $100.00 \%$ & $30.3 \%$ & 665.4 & 0.0132 & 0.0013 & 1.3653 & 0.0176 & 0.0375 & 0.0375 & 0.0119 & 0.4654 \\
\hline Oil & & $35.7 \%$ & 755.7 & 0.0324 & 0.0065 & 11.2995 & 0.9494 & 0.1609 & 0.0420 & 0.0062 & 0.0221 \\
\hline ICE & $100.00 \%$ & $35.7 \%$ & 755.7 & 0.0324 & 0.0065 & 11.2995 & 0.9494 & 0.1609 & 0.0420 & 0.0062 & 0.0221 \\
\hline \multicolumn{12}{|c|}{ Renewable } \\
\hline WAT & $49.14 \%$ & & & & & & & & & & \\
\hline WND & $50.86 \%$ & & & & & & & & & & \\
\hline
\end{tabular}




\subsection{ELECTRICITY GENERATION MIXES}

Electricity generation mixes are calculated as a national average, by NERC region, and by state, on the basis of the net electricity generation for each fuel type, as shown in Tables 16-18.

TABLE 16 Nationally averaged electricity generation mix (\%)

\begin{tabular}{|c|c|c|c|c|c|c|c|c|c|c|c|}
\hline & \multirow[b]{2}{*}{ Coal } & \multirow[b]{2}{*}{ NG } & \multirow[b]{2}{*}{ Oil } & \multirow[b]{2}{*}{ Biomass } & \multirow[b]{2}{*}{ Nuclear } & \multicolumn{6}{|c|}{ Of the other EGUs } \\
\hline & & & & & & $\begin{array}{l}\text { Other } \\
\text { EGUs }\end{array}$ & $\begin{array}{l}\text { Hydro- } \\
\text { electric }\end{array}$ & $\begin{array}{l}\text { Geo- } \\
\text { thermal }\end{array}$ & Wind & $\begin{array}{l}\text { Solar } \\
\text { PV }\end{array}$ & $\begin{array}{l}\text { Waste } \\
\text { heat }\end{array}$ \\
\hline eGRID & 50.04 & 21.89 & 1.65 & 1.47 & 17.96 & 6.99 & 82.39 & 5.03 & 11.85 & 0.0051 & 0.73 \\
\hline $\mathrm{AEO}$ & 46.4 & 22.9 & 1.0 & 0.2 & 20.3 & 9.2 & 65.9 & 4.6 & 25 & 0.4 & 4.1 \\
\hline
\end{tabular}

There are some discrepancies between the eGRID-based electricity generation mix and the one reported in EIA's Annual Energy Outlook (AEO), particularly for the coal and nuclear power shares. As we realize that there has been a decreasing trend in the coal-fired power plant share of the electricity generation mix, mostly due to the increasing share of NG-fired power plants and renewable power plants over the past decade, we decided to use the electricity generation mixes in AEO 2011 for year 2010 in GREET, to be consistent with the historical and future electricity generation mixes in GREET, which are also based on the AEO. 
TABLE 17 Electricity generation mixes (\%) by NERC region based on eGRID

\begin{tabular}{|c|c|c|c|c|c|c|c|c|c|c|c|}
\hline \multirow{2}{*}{$\begin{array}{l}\text { NERC region } \\
\text { (Share) }\end{array}$} & \multirow[b]{2}{*}{ Biomass } & \multirow[b]{2}{*}{ Coal } & \multirow[b]{2}{*}{ NG } & \multirow[b]{2}{*}{ Nuclear } & \multirow[b]{2}{*}{ Oil } & \multirow{2}{*}{$\begin{array}{l}\text { Other } \\
\text { EGUs }\end{array}$} & \multicolumn{5}{|c|}{ Of the Other EGUs } \\
\hline & & & & & & & SUN & GEO & WAT & $\mathrm{WH}$ & WND \\
\hline ASCC (0.2\%) & $0.0 \%$ & $9.5 \%$ & $56.7 \%$ & $0.0 \%$ & $15.2 \%$ & $18.5 \%$ & $0.0 \%$ & $0.0 \%$ & $100.0 \%$ & $0.0 \%$ & $0.0 \%$ \\
\hline FRCC (5.3\%) & $2.4 \%$ & $33.4 \%$ & $54.0 \%$ & $5.2 \%$ & $4.4 \%$ & $0.6 \%$ & $0.0 \%$ & $0.0 \%$ & $0.5 \%$ & $99.5 \%$ & $0.0 \%$ \\
\hline HICC (0.3\%) & $4.3 \%$ & $13.4 \%$ & $0.6 \%$ & $0.0 \%$ & $77.0 \%$ & $4.8 \%$ & $0.0 \%$ & $41.5 \%$ & $15.4 \%$ & $0.0 \%$ & $43.0 \%$ \\
\hline MRO (5.2\%) & $1.5 \%$ & $71.5 \%$ & $5.1 \%$ & $15.5 \%$ & $0.1 \%$ & $6.3 \%$ & $0.0 \%$ & $0.0 \%$ & $52.6 \%$ & $0.0 \%$ & $47.4 \%$ \\
\hline NPCC (6.8\%) & $4.1 \%$ & $15.0 \%$ & $37.3 \%$ & $28.1 \%$ & $4.4 \%$ & $11.0 \%$ & $0.0 \%$ & $0.0 \%$ & $97.0 \%$ & $0.0 \%$ & $3.0 \%$ \\
\hline RFC (24.2\%) & $0.6 \%$ & $65.2 \%$ & $7.0 \%$ & $22.9 \%$ & $3.6 \%$ & $0.7 \%$ & $0.0 \%$ & $0.0 \%$ & $75.4 \%$ & $5.1 \%$ & $19.5 \%$ \\
\hline SERC (27.2\%) & $2.1 \%$ & $59.2 \%$ & $13.0 \%$ & $23.9 \%$ & $0.0 \%$ & $1.7 \%$ & $0.0 \%$ & $0.0 \%$ & $99.6 \%$ & $0.1 \%$ & $0.3 \%$ \\
\hline SPP (5.1\%) & $1.4 \%$ & $65.6 \%$ & $23.0 \%$ & $4.9 \%$ & $0.0 \%$ & $5.2 \%$ & $0.0 \%$ & $0.0 \%$ & $57.8 \%$ & $0.1 \%$ & $42.1 \%$ \\
\hline TRE (8.2\%) & $0.0 \%$ & $35.1 \%$ & $50.2 \%$ & $12.0 \%$ & $0.0 \%$ & $2.7 \%$ & $0.0 \%$ & $0.0 \%$ & $9.8 \%$ & $2.5 \%$ & $87.7 \%$ \\
\hline WECC (17.7\%) & $1.0 \%$ & $30.7 \%$ & $31.8 \%$ & $9.6 \%$ & $0.0 \%$ & $26.8 \%$ & $0.01 \%$ & $7.3 \%$ & $86.1 \%$ & $0.1 \%$ & $6.4 \%$ \\
\hline
\end{tabular}


TABLE 18 Electricity generation mixes (\%) by state based on eGRID

\begin{tabular}{|c|c|c|c|c|c|c|c|c|c|c|c|}
\hline \multirow[b]{2}{*}{ State (Share) } & \multirow[b]{2}{*}{ Biomass } & \multirow[b]{2}{*}{ Coal } & \multirow[b]{2}{*}{ NG } & \multirow[b]{2}{*}{ Nuclear } & \multirow[b]{2}{*}{ Oil } & \multirow[b]{2}{*}{ Other EGUs } & \multicolumn{5}{|c|}{ Of the Other EGUs } \\
\hline & & & & & & & SUN & GEO & WAT & WH & WND \\
\hline AK $(0.16 \%)$ & $0.00 \%$ & $9.54 \%$ & $56.70 \%$ & $0.00 \%$ & $15.22 \%$ & $18.54 \%$ & $0.00 \%$ & $0.00 \%$ & $100.00 \%$ & $0.00 \%$ & $0.00 \%$ \\
\hline AL (3.45\%) & $3.08 \%$ & $57.23 \%$ & $12.94 \%$ & $23.87 \%$ & $0.00 \%$ & $2.88 \%$ & $0.00 \%$ & $0.00 \%$ & $100.00 \%$ & $0.00 \%$ & $0.00 \%$ \\
\hline $\operatorname{AR}(1.31 \%)$ & $3.51 \%$ & $47.01 \%$ & $15.12 \%$ & $28.36 \%$ & $0.00 \%$ & $5.98 \%$ & $0.00 \%$ & $0.00 \%$ & $100.00 \%$ & $0.00 \%$ & $0.00 \%$ \\
\hline AZ (2.72\%) & $0.00 \%$ & $36.85 \%$ & $33.58 \%$ & $23.63 \%$ & $0.00 \%$ & $5.94 \%$ & $0.10 \%$ & $0.00 \%$ & $99.90 \%$ & $0.00 \%$ & $0.00 \%$ \\
\hline CA $(5.07 \%)$ & $1.93 \%$ & $2.08 \%$ & $57.05 \%$ & $16.95 \%$ & $0.03 \%$ & $21.97 \%$ & $0.01 \%$ & $28.00 \%$ & $59.55 \%$ & $0.40 \%$ & $12.04 \%$ \\
\hline CO $(1.3 \%)$ & $0.00 \%$ & $67.65 \%$ & $26.96 \%$ & $0.00 \%$ & $0.01 \%$ & $5.37 \%$ & $0.08 \%$ & $0.00 \%$ & $53.91 \%$ & $1.42 \%$ & $44.59 \%$ \\
\hline CT $(0.8 \%)$ & $3.83 \%$ & $11.89 \%$ & $29.49 \%$ & $49.41 \%$ & $4.35 \%$ & $1.03 \%$ & $0.00 \%$ & $0.00 \%$ & $100.00 \%$ & $0.00 \%$ & $0.00 \%$ \\
\hline DC $(0.0018 \%)$ & $0.00 \%$ & $0.00 \%$ & $0.00 \%$ & $0.00 \%$ & $100.00 \%$ & $0.00 \%$ & $0.00 \%$ & $0.00 \%$ & $0.00 \%$ & $0.00 \%$ & $0.00 \%$ \\
\hline DE $(0.2 \%)$ & $0.00 \%$ & $68.72 \%$ & $31.04 \%$ & $0.00 \%$ & $0.24 \%$ & $0.00 \%$ & $0.00 \%$ & $0.00 \%$ & $0.00 \%$ & $0.00 \%$ & $0.00 \%$ \\
\hline FL (5.54\%) & $2.52 \%$ & $36.53 \%$ & $51.26 \%$ & $4.93 \%$ & $4.15 \%$ & $0.62 \%$ & $0.00 \%$ & $0.00 \%$ & $10.85 \%$ & $89.15 \%$ & $0.00 \%$ \\
\hline GA (3.49\%) & $2.84 \%$ & $62.73 \%$ & $10.65 \%$ & $22.44 \%$ & $0.02 \%$ & $1.32 \%$ & $0.00 \%$ & $0.00 \%$ & $100.00 \%$ & $0.00 \%$ & $0.00 \%$ \\
\hline HI (0.28\%) & $4.28 \%$ & $13.36 \%$ & $0.61 \%$ & $0.00 \%$ & $76.95 \%$ & $4.80 \%$ & $0.00 \%$ & $41.54 \%$ & $15.43 \%$ & $0.00 \%$ & $43.04 \%$ \\
\hline IA (1.19\%) & $0.00 \%$ & $77.12 \%$ & $6.09 \%$ & $9.08 \%$ & $0.24 \%$ & $7.47 \%$ & $0.00 \%$ & $0.00 \%$ & $25.87 \%$ & $0.00 \%$ & $74.13 \%$ \\
\hline ID (0.28\%) & $4.44 \%$ & $0.81 \%$ & $14.69 \%$ & $0.00 \%$ & $0.00 \%$ & $80.06 \%$ & $0.00 \%$ & $0.00 \%$ & $98.13 \%$ & $0.00 \%$ & $1.87 \%$ \\
\hline IL (4.8\%) & $0.00 \%$ & $47.65 \%$ & $4.14 \%$ & $47.80 \%$ & $0.02 \%$ & $0.38 \%$ & $0.00 \%$ & $0.00 \%$ & $12.19 \%$ & $0.00 \%$ & $87.81 \%$ \\
\hline IN (3.13\%) & $0.03 \%$ & $94.35 \%$ & $5.00 \%$ & $0.00 \%$ & $0.00 \%$ & $0.62 \%$ & $0.00 \%$ & $0.00 \%$ & $55.33 \%$ & $44.67 \%$ & $0.00 \%$ \\
\hline KS (1.2\%) & $0.00 \%$ & $73.07 \%$ & $3.91 \%$ & $20.69 \%$ & $0.01 \%$ & $2.32 \%$ & $0.00 \%$ & $0.00 \%$ & $0.90 \%$ & $0.00 \%$ & $99.10 \%$ \\
\hline KY (2.33\%) & $0.39 \%$ & $96.95 \%$ & $0.94 \%$ & $0.00 \%$ & $0.00 \%$ & $1.72 \%$ & $0.00 \%$ & $0.00 \%$ & $100.00 \%$ & $0.00 \%$ & $0.00 \%$ \\
\hline LA (2.22\%) & $4.21 \%$ & $28.72 \%$ & $47.70 \%$ & $18.45 \%$ & $0.00 \%$ & $0.91 \%$ & $0.00 \%$ & $0.00 \%$ & $97.68 \%$ & $2.32 \%$ & $0.00 \%$ \\
\hline MA (1.15\%) & $3.89 \%$ & $26.17 \%$ & $53.94 \%$ & $10.88 \%$ & $5.22 \%$ & $0.00 \%$ & $0.00 \%$ & $0.00 \%$ & $100.00 \%$ & $0.00 \%$ & $0.00 \%$ \\
\hline MD (1.2\%) & $1.32 \%$ & $62.98 \%$ & $3.57 \%$ & $28.59 \%$ & $0.25 \%$ & $3.29 \%$ & $0.00 \%$ & $0.00 \%$ & $100.00 \%$ & $0.00 \%$ & $0.00 \%$ \\
\hline ME (0.39\%) & $29.91 \%$ & $0.00 \%$ & $44.19 \%$ & $0.00 \%$ & $3.79 \%$ & $22.12 \%$ & $0.00 \%$ & $0.00 \%$ & $97.22 \%$ & $0.00 \%$ & $2.78 \%$ \\
\hline MI (2.86\%) & $1.96 \%$ & $61.03 \%$ & $10.18 \%$ & $19.68 \%$ & $7.05 \%$ & $0.11 \%$ & $0.00 \%$ & $0.00 \%$ & $97.83 \%$ & $0.00 \%$ & $2.17 \%$ \\
\hline MN (1.31\%) & $2.89 \%$ & $60.83 \%$ & $6.17 \%$ & $24.03 \%$ & $0.16 \%$ & $5.92 \%$ & $0.00 \%$ & $0.00 \%$ & $18.35 \%$ & $0.00 \%$ & $81.65 \%$ \\
\hline MO (2.19\%) & $0.00 \%$ & $83.10 \%$ & $4.86 \%$ & $10.28 \%$ & $0.01 \%$ & $1.74 \%$ & $0.00 \%$ & $0.00 \%$ & $100.00 \%$ & $0.00 \%$ & $0.00 \%$ \\
\hline MS (1.2\%) & $2.92 \%$ & $41.68 \%$ & $36.64 \%$ & $18.77 \%$ & $0.00 \%$ & $0.00 \%$ & $0.00 \%$ & $0.00 \%$ & $0.00 \%$ & $0.00 \%$ & $0.00 \%$ \\
\hline
\end{tabular}


TABLE 18 (Cont.)

\begin{tabular}{|c|c|c|c|c|c|c|c|c|c|c|c|}
\hline State (Share) & Biomass & Coal & NG & Nuclear & Oil & Other EGUs & \multicolumn{5}{|c|}{ Of the Other EGUs } \\
\hline MT (0.69\%) & $0.42 \%$ & $65.17 \%$ & $0.33 \%$ & $0.00 \%$ & $0.00 \%$ & $34.08 \%$ & $0.00 \%$ & $0.00 \%$ & $94.97 \%$ & $0.00 \%$ & $5.03 \%$ \\
\hline NC (3.12\%) & $1.36 \%$ & $61.90 \%$ & $3.56 \%$ & $30.77 \%$ & $0.06 \%$ & $2.34 \%$ & $0.00 \%$ & $0.00 \%$ & $100.00 \%$ & $0.00 \%$ & $0.00 \%$ \\
\hline ND (0.75\%) & $0.04 \%$ & $93.54 \%$ & $0.23 \%$ & $0.00 \%$ & $0.01 \%$ & $6.17 \%$ & $0.00 \%$ & $0.00 \%$ & $67.77 \%$ & $0.00 \%$ & $32.23 \%$ \\
\hline NE $(0.79 \%)$ & $0.00 \%$ & $59.84 \%$ & $3.43 \%$ & $33.54 \%$ & $0.03 \%$ & $3.16 \%$ & $0.00 \%$ & $0.00 \%$ & $79.13 \%$ & $0.00 \%$ & $20.87 \%$ \\
\hline NH (0.56\%) & $3.38 \%$ & $18.29 \%$ & $25.15 \%$ & $46.29 \%$ & $1.45 \%$ & $5.44 \%$ & $0.00 \%$ & $0.00 \%$ & $100.00 \%$ & $0.00 \%$ & $0.00 \%$ \\
\hline NJ (1.51\%) & $1.77 \%$ & $16.95 \%$ & $30.48 \%$ & $21.03 \%$ & $30.13 \%$ & $0.00 \%$ & $0.00 \%$ & $0.00 \%$ & $108.97 \%$ & $0.00 \%$ & $-8.97 \%$ \\
\hline NM (0.86\%) & $0.00 \%$ & $76.91 \%$ & $18.47 \%$ & $0.00 \%$ & $0.00 \%$ & $4.62 \%$ & $0.00 \%$ & $0.00 \%$ & $16.13 \%$ & $0.00 \%$ & $83.87 \%$ \\
\hline NV (0.79\%) & $0.00 \%$ & $21.61 \%$ & $68.46 \%$ & $0.00 \%$ & $0.00 \%$ & $9.93 \%$ & $0.08 \%$ & $38.44 \%$ & $61.47 \%$ & $0.00 \%$ & $0.00 \%$ \\
\hline NY (3.49\%) & $1.66 \%$ & $15.18 \%$ & $31.14 \%$ & $29.37 \%$ & $5.18 \%$ & $17.48 \%$ & $0.00 \%$ & $0.00 \%$ & $96.70 \%$ & $0.00 \%$ & $3.30 \%$ \\
\hline $\mathrm{OH}(3.71 \%)$ & $0.09 \%$ & $86.68 \%$ & $2.76 \%$ & $10.19 \%$ & $0.00 \%$ & $0.27 \%$ & $0.00 \%$ & $0.00 \%$ & $96.53 \%$ & $0.00 \%$ & $3.47 \%$ \\
\hline OK (1.8\%) & $0.55 \%$ & $52.96 \%$ & $40.15 \%$ & $0.00 \%$ & $0.00 \%$ & $6.35 \%$ & $0.00 \%$ & $0.00 \%$ & $61.06 \%$ & $0.00 \%$ & $38.94 \%$ \\
\hline OR (1.32\%) & $2.85 \%$ & $7.91 \%$ & $26.00 \%$ & $0.00 \%$ & $0.00 \%$ & $63.25 \%$ & $0.00 \%$ & $0.00 \%$ & $96.42 \%$ & $0.00 \%$ & $3.58 \%$ \\
\hline PA (5.43\%) & $0.89 \%$ & $55.20 \%$ & $8.68 \%$ & $34.26 \%$ & $0.10 \%$ & $0.88 \%$ & $0.00 \%$ & $0.00 \%$ & $76.30 \%$ & $0.00 \%$ & $23.70 \%$ \\
\hline RI (0.17\%) & $0.00 \%$ & $0.00 \%$ & $99.79 \%$ & $0.00 \%$ & $0.15 \%$ & $0.06 \%$ & $0.00 \%$ & $0.00 \%$ & $100.00 \%$ & $0.00 \%$ & $0.00 \%$ \\
\hline SC (2.51\%) & $2.41 \%$ & $46.61 \%$ & $4.93 \%$ & $45.90 \%$ & $0.01 \%$ & $0.14 \%$ & $0.00 \%$ & $0.00 \%$ & $100.00 \%$ & $0.00 \%$ & $0.00 \%$ \\
\hline SD (0.14\%) & $0.00 \%$ & $47.08 \%$ & $6.97 \%$ & $0.00 \%$ & $0.16 \%$ & $45.79 \%$ & $0.00 \%$ & $0.00 \%$ & $94.21 \%$ & $0.00 \%$ & $5.79 \%$ \\
\hline TN (2.3\%) & $1.21 \%$ & $63.58 \%$ & $0.52 \%$ & $30.17 \%$ & $0.00 \%$ & $4.51 \%$ & $0.00 \%$ & $0.00 \%$ & $98.83 \%$ & $0.00 \%$ & $1.17 \%$ \\
\hline TX (9.73\%) & $0.28 \%$ & $36.92 \%$ & $50.02 \%$ & $10.10 \%$ & $0.00 \%$ & $2.69 \%$ & $0.00 \%$ & $0.00 \%$ & $15.10 \%$ & $2.22 \%$ & $82.69 \%$ \\
\hline UT (1.09\%) & $0.02 \%$ & $82.00 \%$ & $16.42 \%$ & $0.00 \%$ & $0.00 \%$ & $1.55 \%$ & $0.00 \%$ & $23.33 \%$ & $76.67 \%$ & $0.00 \%$ & $0.00 \%$ \\
\hline VA (1.91\%) & $4.63 \%$ & $47.84 \%$ & $13.08 \%$ & $34.80 \%$ & $0.12 \%$ & $0.00 \%$ & $0.00 \%$ & $0.00 \%$ & $100.00 \%$ & $0.00 \%$ & $0.00 \%$ \\
\hline VT (0.14\%) & $7.81 \%$ & $0.00 \%$ & $0.00 \%$ & $80.77 \%$ & $0.95 \%$ & $10.47 \%$ & $0.00 \%$ & $0.00 \%$ & $98.28 \%$ & $0.00 \%$ & $1.72 \%$ \\
\hline WA (2.57\%) & $1.31 \%$ & $8.30 \%$ & $6.81 \%$ & $7.58 \%$ & $0.00 \%$ & $76.00 \%$ & $0.00 \%$ & $0.00 \%$ & $97.00 \%$ & $0.00 \%$ & $3.00 \%$ \\
\hline WI (1.52\%) & $1.50 \%$ & $65.32 \%$ & $10.37 \%$ & $7.30 \%$ & $13.21 \%$ & $2.31 \%$ & $0.00 \%$ & $0.00 \%$ & $92.53 \%$ & $0.00 \%$ & $7.47 \%$ \\
\hline WV (2.25\%) & $0.00 \%$ & $98.11 \%$ & $0.35 \%$ & $0.00 \%$ & $0.03 \%$ & $1.51 \%$ & $0.00 \%$ & $0.00 \%$ & $88.21 \%$ & $0.00 \%$ & $11.79 \%$ \\
\hline WY (1.09\%) & $0.00 \%$ & $94.80 \%$ & $1.94 \%$ & $0.00 \%$ & $0.00 \%$ & $3.25 \%$ & $0.00 \%$ & $0.00 \%$ & $49.14 \%$ & $0.00 \%$ & $50.86 \%$ \\
\hline
\end{tabular}




\subsection{ELECTRICITY TRANSMISSION AND DISTRIBUTION LOSS}

The electricity transmission and distribution (T\&D) loss factors (\%) on a national and state average basis were calculated by dividing the estimated losses by the result of total disposed electricity minus directly used electricity, i.e., net generated electricity, which are obtained from EIA's State Electricity Profiles 2010 (EIA, 2011). The results are shown in Table 19.

TABLE 19 Electricity T\&D gross grid loss factors (\%) on a state and national average basis

\begin{tabular}{|c|c|c|c|c|c|c|c|c|}
\hline & 2000 & 2004 & 2005 & 2006 & 2007 & 2008 & 2009 & 2010 \\
\hline AL & 5.03 & 4.39 & 4.31 & 4.57 & 5.69 & 4.86 & 4.16 & 4.64 \\
\hline AK & 7.43 & 6.63 & 7.73 & 7.89 & 7.79 & 8.10 & 6.80 & 7.56 \\
\hline $\mathrm{AZ}^{1}$ & 4.91 & 4.38 & 5.31 & 5.19 & 5.94 & 5.37 & 5.35 & $\mathrm{NA}^{2}$ \\
\hline AR & 7.13 & 7.45 & 8.93 & 6.88 & 8.96 & 7.75 & 7.32 & 7.82 \\
\hline CA & 8.73 & 10.64 & 9.56 & 10.19 & 11.12 & 11.33 & 11.03 & 8.87 \\
\hline $\mathrm{CO}$ & 7.00 & 8.12 & 8.87 & 8.60 & 5.77 & 8.56 & 8.51 & 8.01 \\
\hline $\mathrm{CT}^{3}$ & 6.74 & 4.48 & 4.56 & 5.57 & 6.73 & 8.94 & 5.13 & NA \\
\hline $\mathrm{DE}^{4}$ & NA & NA & NA & NA & NA & NA & NA & NA \\
\hline FL & 7.53 & 7.16 & 7.54 & 7.92 & 8.70 & 8.27 & 7.82 & 8.36 \\
\hline GA & 7.17 & 16.88 & 8.58 & 6.98 & 8.70 & 10.01 & 9.08 & 8.61 \\
\hline HI & 6.83 & 4.79 & 5.78 & 6.08 & 6.84 & 6.53 & 6.12 & 6.01 \\
\hline $\mathrm{ID}^{5}$ & NA & NA & NA & NA & NA & NA & NA & NA \\
\hline $\mathrm{IL}^{6}$ & 5.53 & 5.09 & 5.84 & 5.91 & 5.43 & 4.81 & 4.15 & NA \\
\hline IN & 5.65 & 5.77 & 9.01 & 5.24 & 6.40 & 5.70 & 6.08 & 5.95 \\
\hline $\mathrm{IA}^{7}$ & 6.92 & 6.38 & 5.69 & 6.61 & 6.35 & 4.93 & 4.87 & NA \\
\hline KS & 5.71 & 7.40 & 9.33 & 7.60 & 8.32 & 8.61 & 8.17 & 8.29 \\
\hline KY & 6.02 & 7.17 & 6.87 & 6.62 & 8.51 & 6.71 & 5.56 & 6.52 \\
\hline LA & 8.27 & 6.82 & 7.66 & 8.10 & 9.11 & 8.14 & 7.99 & 7.14 \\
\hline $\mathrm{ME}^{8}$ & 6.28 & NA & NA & NA & NA & NA & NA & NA \\
\hline $\mathrm{MD}^{9}$ & 8.69 & 9.22 & 10.30 & 9.94 & NA & NA & 11.34 & 11.28 \\
\hline MA & 9.29 & 4.85 & 4.75 & 8.81 & 8.87 & 7.65 & 5.92 & 5.44 \\
\hline MI & 7.26 & 6.69 & 6.58 & 7.47 & 7.91 & 7.58 & 7.74 & 7.31 \\
\hline MN & 7.47 & 9.67 & 8.18 & 7.91 & 7.18 & 7.28 & 9.72 & 7.57 \\
\hline MS & 9.15 & 8.41 & 8.44 & 8.42 & 9.23 & 8.91 & 7.86 & 7.71 \\
\hline MO & 6.78 & 6.87 & 7.50 & 7.35 & 7.81 & 7.50 & 6.47 & 7.11 \\
\hline $\mathrm{MT}^{10}$ & 3.96 & 11.50 & NA & NA & NA & NA & NA & NA \\
\hline $\mathrm{NE}$ & 5.97 & 6.63 & 7.40 & 7.71 & 8.58 & 8.67 & 7.91 & 7.53 \\
\hline $\mathrm{NV}$ & 5.03 & 4.39 & 4.31 & 4.57 & 5.69 & 4.86 & 4.16 & 4.64 \\
\hline $\mathrm{NH}^{11}$ & 4.37 & NA & NA & NA & NA & NA & NA & NA \\
\hline NJ & 8.94 & 10.70 & 11.24 & 10.39 & 10.75 & 8.61 & 7.21 & 10.94 \\
\hline NM & 4.00 & 4.00 & 5.03 & 4.98 & 4.83 & 4.99 & 4.97 & 5.97 \\
\hline
\end{tabular}


TABLE 19 (Cont.)

\begin{tabular}{|c|c|c|c|c|c|c|c|c|}
\hline & 2000 & 2004 & 2005 & 2006 & 2007 & 2008 & 2009 & 2010 \\
\hline NY & 7.00 & 10.57 & 7.81 & 4.38 & 5.67 & 5.57 & 6.27 & 5.85 \\
\hline $\mathrm{NC}$ & 7.19 & 7.29 & 10.25 & 10.90 & 8.49 & 8.37 & 8.14 & 7.64 \\
\hline $\mathrm{ND}^{12}$ & NA & 6.82 & 4.67 & 4.79 & 4.88 & 4.63 & 4.91 & 4.76 \\
\hline $\mathrm{OH}$ & 7.97 & 8.66 & 6.76 & 7.15 & 7.99 & 7.91 & 7.83 & 5.66 \\
\hline OK & 6.50 & 5.76 & 6.24 & 6.77 & 7.77 & 7.21 & 6.97 & 7.23 \\
\hline OR & 7.00 & 5.42 & 6.64 & 6.82 & 6.87 & 6.44 & 5.91 & 5.76 \\
\hline PA & 4.83 & 5.24 & 5.43 & 5.22 & 5.42 & 5.00 & 4.55 & 5.05 \\
\hline $\mathrm{RI}^{13}$ & 6.62 & 8.03 & 7.17 & 8.34 & 8.23 & NA & 4.75 & 5.22 \\
\hline SC & 6.00 & 5.10 & 5.61 & 5.60 & 6.23 & 6.05 & 5.64 & 5.59 \\
\hline $\mathrm{SD}^{14}$ & 6.08 & NA & NA & NA & NA & NA & NA & 8.60 \\
\hline $\mathrm{TN}$ & 7.36 & 5.18 & 6.32 & 5.92 & 7.29 & 6.46 & 6.29 & 8.64 \\
\hline $\mathrm{TX}$ & 6.76 & 5.78 & 4.13 & 4.73 & 5.66 & 7.22 & 6.08 & 6.39 \\
\hline UT & 4.55 & 4.91 & 5.70 & 5.76 & 5.91 & 5.64 & 5.47 & 6.37 \\
\hline $\mathrm{VT}^{15}$ & NA & 4.92 & 5.12 & 4.22 & 5.28 & 4.66 & NA & 4.91 \\
\hline $\mathrm{VA}^{16}$ & 9.26 & 8.15 & 9.31 & NA & 10.76 & 8.79 & 8.72 & 11.15 \\
\hline WA & 6.18 & 4.38 & 5.79 & 4.81 & 5.58 & 5.20 & 4.78 & 4.83 \\
\hline $\mathrm{WV}^{17}$ & NA & NA & NA & NA & NA & NA & NA & NA \\
\hline WI & 8.15 & 7.70 & 7.11 & 6.10 & 7.78 & 7.48 & 6.28 & 6.01 \\
\hline $\mathrm{WY}^{18}$ & NA & NA & NA & NA & NA & NA & NA & NA \\
\hline United States $^{19}$ & 6.62 & 6.93 & 6.82 & 6.72 & 7.29 & 7.10 & 6.72 & 6.49 \\
\hline
\end{tabular}

${ }^{1}$ Original EIA-calculated number is 3.70 in 2010.

${ }^{2}$ Not available.

${ }^{3}$ Original EIA-calculated number is 3.27 in 2010.

${ }^{4}$ Original EIA-calculated numbers are 14.60, 14.63, 16.52, 14.74, 17.10, 12.99, 18.56, and 16.89 in 2000 and 2004-2010, respectively.

${ }^{5}$ Original EIA-calculated numbers are 14.32, 16.17, 19.33, 18.50, 21.11, 20.74, 16.11, and 17.18 in 2000 and 2004-2010, respectively.

${ }^{6}$ Original EIA-calculated number is 3.86 in 2010.

${ }^{7}$ Original EIA-calculated number is 53.39 in 2010.

${ }^{8}$ Original EIA-calculated numbers are 2.40, 2.61, 2.31, 2.28, 3.03, 2.14, and 1.79 in 2004-2010, respectively.

${ }^{9}$ Original EIA-calculated numbers are 12.19 and 12.31in 2007 and 2008, respectively.

${ }^{10}$ Original EIA-calculated numbers are 13.31, 12.67, 12.28, 15.55, and 22.73 in 2005-2009, respectively.

${ }^{11}$ Original EIA-calculated numbers are 2.59, 2.69, 3.09, 3.33, 3.19, 2.24, 2.94 in 2004-2010, respectively.

${ }^{12}$ Original EIA-calculated number is 2.06 in 2000.

${ }^{13}$ Original EIA-calculated number is 1.92 in 2008.

${ }^{14}$ Original EIA-calculated numbers are 14.57, 13.92, 12.23, 16.59, 14.83, and 12.42 in 2004-2009, respectively.

${ }^{15}$ Original EIA-calculated numbers are 3.81 and 3.04 in 2000 and 2009, respectively.

${ }^{16}$ Original EIA-calculated number is 12.81 in 2006.

${ }^{17}$ Original EIA-calculated numbers are 2.16, 2.04, 2.80, 3.25, 3.51, 3.66, 3.60, and 3.45 in 2000 and 2004-2010, respectively.

${ }^{18}$ Original EIA-calculated number are 1.96, 2.28, 2.45, 2.77, 3.03, 3.27, 2.94 and 2.90 in 2000 and 2004-2010, respectively.

${ }^{19}$ EIA-calculated numbers on an end-use weighted-average basis (EIA, 2011). 
On the basis of Table 19, the U.S. average T\&D loss factor will be updated from $8 \%$ to $6.5 \%$ for 2010 in GREET 1_2012.

\subsection{PROBABILITY DISTRIBUTION FUNCTIONS OF GHG AND CAP EMISSION FACTORS AND ENERGY EFFICIENCIES BY FUEL TYPE AND COMBUSTION TECHNOLOGY OF EGUS}

Table 20 summarizes the PDFs of energy efficiency and GHG and CAP emission factors by fuel type and combustion technology for EGUs on a national-average basis. Both the best-fit PDFs based on the eleven default PDFs in GREET's Add-on Stochastic Tool and the best-fit PDFs from a comprehensive pool of PDFs in EasyFit were developed to give dual options for users, based on their access to the stochastic simulation tools, to perform uncertainty analysis of lifecycle GHG and CAP emissions of various vehicle/fuel systems. 
TABLE 20 Probability distribution functions of energy efficiency, GHG and CAP emission factors by fuel type and combustion technology of EGUs

\begin{tabular}{|c|c|c|c|c|c|c|c|c|c|c|c|}
\hline \multirow{2}{*}{ Fuel type } & \multirow{2}{*}{$\begin{array}{l}\text { Gener- } \\
\text { ation } \\
\text { Tech- } \\
\text { nology }\end{array}$} & \multirow{2}{*}{$\begin{array}{l}\text { Efficiency, } \\
\text { GHG, } \\
\text { CAP }\end{array}$} & \multicolumn{5}{|c|}{ Best of best } & \multicolumn{4}{|c|}{ Best of eleven } \\
\hline & & & PDF Type & & PDF & ameters & & PDF Type & & PDF Param & \\
\hline \multirow[t]{10}{*}{ Coal } & BLR & Efficiency & $\begin{array}{l}\text { Logistic } \\
\text { (sigma, mu) }\end{array}$ & 0.01662 & 0.34827 & & & Logistic & 0.01662 & 0.34827 & \\
\hline & & $\mathrm{CO}_{2}$ & $\begin{array}{l}\text { Burr (k, alpha, } \\
\text { beta, gamma) }\end{array}$ & 0.71435 & 20.839 & 943.31 & 0 & $\begin{array}{l}\text { Gamma } \\
\text { (alpha, beta, } \\
\text { gamma) }\end{array}$ & 13.235 & 26.647 & 622.46 \\
\hline & & $\mathrm{CH}_{4}$ & Burr & 0.61648 & 23.506 & 0.01063 & 0 & Gamma & 7.5929 & 3.84E-04 & 0.00819 \\
\hline & & $\mathrm{N}_{2} \mathrm{O}$ & $\begin{array}{l}\text { Dagum (k, } \\
\text { alpha, beta, } \\
\text { gamma) }\end{array}$ & 0.87227 & 19.317 & 0.01654 & 0 & Logistic & $9.06 \mathrm{E}-04$ & 0.01642 & \\
\hline & & $\mathrm{NO}_{\mathrm{x}}$ & Dagum & 0.29521 & 5.799 & 1.7364 & 0.13662 & Gamma & 8.1772 & 0.22238 & -0.44698 \\
\hline & & $\mathrm{SO}_{\mathrm{x}}$ & Dagum & 0.40774 & 2.9293 & 5.216 & 0 & Gamma & 1.5808 & 2.4629 & 0 \\
\hline & & $\mathrm{PM}_{10}$ & $\begin{array}{l}\text { Johnson SB } \\
\text { (gamma, delta, } \\
\text { lambda, xi) }\end{array}$ & 0.15061 & 0.4292 & 0.32148 & -0.00315 & $\begin{array}{l}\text { Uniform } \\
\text { (min, max) }\end{array}$ & 0 & 0.32782 & \\
\hline & & $\mathrm{PM}_{2.5}$ & $\begin{array}{l}\text { Gen. Gamma } \\
\text { (k, alpha, beta, } \\
\text { gamma) }\end{array}$ & 2.5624 & 0.23192 & 0.31314 & $3.4597 \mathrm{E}-5$ & Gamma & 0.75895 & 0.15778 & 3.50E-05 \\
\hline & & VOC & Burr & 0.71244 & 9.8929 & 0.01214 & $9.70 \mathrm{E}-05$ & $\begin{array}{l}\text { Lognormal } \\
\text { (sigma, mu) }\end{array}$ & 0.22452 & -4.3457 & \\
\hline & & $\mathrm{CO}$ & Burr & 1.9823 & 8.2229 & 0.11858 & 0 & Logistic & 0.01071 & 0.10689 & \\
\hline \multirow[t]{6}{*}{$\begin{array}{l}\text { Natural } \\
\text { gas }\end{array}$} & BLR & Efficiency & $\begin{array}{l}\text { Cauchy } \\
\text { (sigma, mu) }\end{array}$ & 0.01537 & 0.33108 & & & Logistic & 0.02183 & 0.33049 & \\
\hline & & $\mathrm{CO}_{2}$ & Cauchy & 27.469 & 622.21 & & & Lognormal & 0.12105 & 6.4417 & \\
\hline & & $\mathrm{CH}_{4}$ & Cauchy & 6.23E-04 & 0.01199 & & & Lognormal & 0.17885 & -4.3759 & \\
\hline & & $\mathrm{N}_{2} \mathrm{O}$ & Cauchy & 7.03E-05 & 0.00121 & & & Lognormal & 0.13508 & -6.7084 & \\
\hline & & $\mathrm{NO}_{\mathrm{x}}$ & Johnson SB & 1.1552 & 0.97946 & 3.8044 & -0.19597 & Gamma & 1.5767 & 0.53551 & \\
\hline & & $\mathrm{SO}_{\mathrm{x}}$ & Dagum & 0.5521 & 1.4298 & 0.014 & 0 & Weibull & 0.64099 & 0.01402 & \\
\hline
\end{tabular}


TABLE 20 (Cont.)

\begin{tabular}{|c|c|c|c|c|c|c|c|c|c|c|c|}
\hline \multirow{2}{*}{ Fuel type } & \multirow{2}{*}{$\begin{array}{l}\text { Gener- } \\
\text { ation } \\
\text { Tech- } \\
\text { nology }\end{array}$} & \multirow{2}{*}{$\begin{array}{l}\text { Efficiency, } \\
\text { GHG, } \\
\text { CAP }\end{array}$} & \multicolumn{5}{|c|}{ Best of best } & \multicolumn{4}{|c|}{ Best of eleven } \\
\hline & & & \multicolumn{2}{|l|}{ PDF Type } & \multicolumn{3}{|c|}{ PDF Parameters } & \multicolumn{2}{|l|}{ PDF Type } & \multicolumn{2}{|c|}{ PDF Parameters } \\
\hline & & $\mathrm{PM}_{10}$ & $\begin{array}{l}\text { Frechet } \\
\text { (alpha, beta, } \\
\text { gamma) }\end{array}$ & 4.0662 & 0.00955 & 0.02595 & & Logistic & 0.00265 & 0.03687 & \\
\hline & & $\mathrm{PM}_{2.5}$ & $\begin{array}{l}\text { Frechet } \\
\text { (alpha, beta, } \\
\text { gamma) }\end{array}$ & 4.0662 & 0.00955 & 0.02595 & & Logistic & 0.00265 & 0.03687 & \\
\hline & & VOC & Cauchy & 0.00121 & 0.02612 & & & Lognormal & 0.12575 & -3.6324 & \\
\hline & & $\mathrm{CO}$ & Cauchy & 0.02005 & 0.39927 & & & Logistic & 0.0393 & 0.40057 & \\
\hline & CT & Efficiency & $\begin{array}{l}\text { Erlang (m, } \\
\text { beta, gamma) }\end{array}$ & 247 & 0.00345 & -0.51541 & & Gamma & 271.64 & 0.0033 & -0.55931 \\
\hline & & $\mathrm{CO}_{2}$ & $\begin{array}{l}\text { Gumbel Max } \\
\text { (sigma, mu) }\end{array}$ & 82.211 & 575.25 & & & Gamma & 3.0396 & 60.669 & 438.29 \\
\hline \multirow{11}{*}{ ने } & & $\mathrm{CH}_{4}$ & Burr & 0.38607 & 16.419 & 0.01069 & 0 & Gamma & 1.7565 & 0.0019 & 0.00902 \\
\hline & & $\mathrm{N}_{2} \mathrm{O}$ & Burr & 0.38838 & 16.824 & 0.00107 & 0 & Gamma & 1.7048 & 1.90E-04 & $9.04 \mathrm{E}-04$ \\
\hline & & $\mathrm{NO}_{\mathrm{x}}$ & Lognormal & 0.85145 & -1.4381 & & & Lognormal & 0.85145 & -1.4381 & \\
\hline & & $\mathrm{SO}_{\mathrm{x}}$ & $\begin{array}{l}\text { Log- } \\
\text { Pearson3(alph } \\
\text { a, gamma, } \\
\text { beta) }\end{array}$ & 2553.3 & -0.03081 & 75.311 & & Lognormal & 1.5566 & -3.3441 & \\
\hline & & $\mathrm{PM}_{10}$ & Pearson 5 & 44.797 & 1.4961 & 0 & & Lognormal & 0.1521 & -3.3881 & \\
\hline & & $\mathrm{PM}_{2.5}$ & Pearson 5 & 44.797 & 1.4961 & 0 & & Lognormal & 0.1521 & -3.3881 & \\
\hline & & VOC & $\begin{array}{l}\text { Pearson } 6 \\
\text { (alpha1, } \\
\text { alpha2, beta, } \\
\text { gamma) }\end{array}$ & 227.49 & 53.581 & 0.00251 & 0 & Lognormal & 0.15211 & -4.5332 & \\
\hline & & $\mathrm{CO}$ & Pearson 5 & 44.796 & 18.587 & 0 & & Lognormal & 0.1521 & -0.86845 & \\
\hline & $\mathrm{CC}$ & Efficiency & Dagum & 0.35393 & 10915 & 112.94 & -112.42 & $\begin{array}{l}\text { Weibull } \\
\text { (alpha, beta, } \\
\text { gamma) }\end{array}$ & 19.851 & 0.57763 & -0.05989 \\
\hline & & $\mathrm{CO}_{2}$ & Burr & 0.68446 & 5.2657 & 57.907 & 336.9 & Gamma & 5.3917 & 12.917 & 339.04 \\
\hline & & $\mathrm{CH}_{4}$ & Burr & 0.40398 & 50.882 & 0.00761 & 0 & Gamma & 9.284 & $1.57 \mathrm{E}-04$ & 0.00647 \\
\hline
\end{tabular}


TABLE 20 (Cont.)

\begin{tabular}{|c|c|c|c|c|c|c|c|c|c|c|c|}
\hline \multirow{3}{*}{ Fuel type } & \multirow{3}{*}{$\begin{array}{l}\text { Gener- } \\
\text { ation } \\
\text { Tech- } \\
\text { nology }\end{array}$} & \multirow{3}{*}{$\begin{array}{l}\text { Efficiency, } \\
\text { GHG, } \\
\text { CAP } \\
\mathrm{N}_{2} \mathrm{O} \\
\end{array}$} & \multicolumn{5}{|c|}{ Best of best } & \multicolumn{4}{|c|}{ Best of eleven } \\
\hline & & & \multicolumn{2}{|l|}{ PDF Type } & \multicolumn{3}{|c|}{ PDF Parameters } & \multirow{2}{*}{$\begin{array}{l}\text { PDF Type } \\
\text { Gamma }\end{array}$} & \multicolumn{3}{|c|}{ PDF Parameters } \\
\hline & & & Burr & 0.35932 & 50.619 & 7.59E-04 & 0 & & 7.0675 & 1.97E-05 & $6.56 \mathrm{E}-04$ \\
\hline & & $\mathrm{NO}_{\mathrm{x}}$ & Pert (m, a, b) & 0.01672 & 0.01672 & 0.31399 & & Weibull & 1.7341 & 0.07173 & 0 \\
\hline & & $\mathrm{SO}_{\mathrm{x}}$ & Gen. Gamma & 0.62 & 2.0995 & 0.00135 & 7.1094E-4 & Lognormal & 0.87044 & -5.476 & \\
\hline & & $\mathrm{PM}_{10}$ & Frechet & 21.279 & $\begin{array}{l}8.0049 \mathrm{E}- \\
04\end{array}$ & 0 & & Gamma & 8.8646 & $1.7166 \mathrm{E}-5$ & $6.7324 \mathrm{E}-4$ \\
\hline & & $\mathrm{PM}_{2.5}$ & Frechet & 21.279 & $\begin{array}{l}8.0049 E- \\
04\end{array}$ & 0 & & Gamma & 8.8646 & $1.7166 \mathrm{E}-5$ & $6.7324 \mathrm{E}-4$ \\
\hline & & VOC & Burr & 0.37778 & 50.825 & 0.00162 & 0 & Gamma & 8.8646 & 3.53E-05 & 0.00138 \\
\hline & & $\mathrm{CO}$ & Cauchy & 0.000928 & 0.02815 & & & Logistic & 0.00283 & 0.02797 & \\
\hline & ICE & Efficiency & Weibull & 5.2046 & 0.3501 & 0 & & Weibull & 5.2046 & 0.3501 & 0 \\
\hline & & $\mathrm{CO}_{2}$ & Cauchy & 32.607 & 484.98 & & & $\begin{array}{l}\text { Triangular } \\
(\mathrm{m}, \mathrm{a}, \mathrm{b})\end{array}$ & 472 & -33.855 & 1179.6 \\
\hline & & $\mathrm{CH}_{4}$ & Cauchy & $6.95 \mathrm{E}-04$ & 0.00964 & & & Logistic & 0.00253 & 0.01006 & \\
\hline & & $\mathrm{N}_{2} \mathrm{O}$ & Burr & 0.39265 & 10.221 & 0.00229 & -0.00151 & Uniform & 0 & 0.00346 & \\
\hline & & $\mathrm{NO}_{\mathrm{x}}$ & Frechet & 1.4637 & 1.6988 & & & Weibull & 1.5134 & 3.5087 & 0 \\
\hline & & $\mathrm{SO}_{\mathrm{x}}$ & $\begin{array}{l}\text { Inv.Gaussian } \\
\text { (lambda, mu, } \\
\text { gamma) }\end{array}$ & 0.02136 & 0.04038 & 0 & & Weibull & 0.83778 & 0.03374 & 0.00141 \\
\hline \multirow{9}{*}{ Oil } & \multirow{9}{*}{ BLR } & $\mathrm{PM}_{10}$ & $\begin{array}{l}\text { Error (k, } \\
\text { sigma, mu) }\end{array}$ & 1.7065 & 0.22548 & 0.46614 & & Logistic & 0.12431 & 0.46614 & \\
\hline & & $\mathrm{PM}_{2.5}$ & Error & 1.7065 & 0.22548 & 0.46614 & & Logistic & 0.12431 & 0.46614 & \\
\hline & & VOC & Error & 1.7065 & 0.53054 & 1.0968 & & Logistic & 0.2925 & 1.0968 & \\
\hline & & $\mathrm{CO}$ & Error & 1.7065 & 1.8249 & 3.7726 & & Logistic & 1.0061 & 3.7726 & \\
\hline & & Efficiency & $\begin{array}{l}\text { Beta (alpha1, } \\
\text { alpha2, a, b) }\end{array}$ & 4.1764 & 0.63941 & 0.15373 & 0.35697 & Weibull & 17.242 & 0.34167 & \\
\hline & & $\mathrm{CO}_{2}$ & Gamma & 65.864 & 12.024 & & & Gamma & 65.864 & 12.024 & \\
\hline & & $\mathrm{CH}_{4}$ & Uniform & 0.01823 & 0.04302 & & & Uniform & 0.01823 & 0.04302 & \\
\hline & & $\mathrm{N}_{2} \mathrm{O}$ & Johnson SB & 0.28694 & 0.74013 & 0.0066 & 0.00308 & Uniform & 0.00304 & 0.00878 & \\
\hline & & $\mathrm{NO}_{\mathrm{x}}$ & Dagum & 0.122 & 15.757 & 2.0294 & 0 & Uniform & 0.41012 & 2.2977 & \\
\hline
\end{tabular}


TABLE 20 (Cont.)

\begin{tabular}{|c|c|c|c|c|c|c|c|c|c|c|c|}
\hline \multirow{3}{*}{ Fuel type } & \multirow{3}{*}{$\begin{array}{l}\text { Gener- } \\
\text { ation } \\
\text { Tech- } \\
\text { nology }\end{array}$} & \multirow{3}{*}{$\begin{array}{l}\text { Efficiency, } \\
\text { GHG, } \\
\text { CAP } \\
\mathrm{SO}_{\mathrm{x}} \\
\end{array}$} & \multicolumn{5}{|c|}{ Best of best } & \multicolumn{4}{|c|}{ Best of eleven } \\
\hline & & & \multicolumn{2}{|l|}{ PDF Type } & \multicolumn{3}{|c|}{ PDF Parameters } & \multirow{2}{*}{$\begin{array}{l}\text { PDF Type } \\
\text { Lognormal }\end{array}$} & \multicolumn{3}{|c|}{ PDF Parameters } \\
\hline & & & Burr & 0.2158 & 8.1622 & 1.6563 & 0 & & 0.54375 & 1.0341 & \\
\hline & & $\mathrm{PM}_{10}$ & Burr & $\begin{array}{l}1.2487 \mathrm{E}+1 \\
3\end{array}$ & 0.74828 & $\begin{array}{l}9.9915 \mathrm{E}+ \\
11\end{array}$ & 0 & Logistic & $\begin{array}{l}2.3552 \mathrm{E}- \\
6\end{array}$ & 2.9309E-6 & Logistic \\
\hline & & $\mathrm{PM}_{2.5}$ & Burr & 1.6154 & 0.52344 & 0.03067 & 0.04765 & Weibull & 0.43755 & 0.06256 & 0.04764 \\
\hline & & VOC & Gen. Gamma & 1.1575 & 0.25775 & $\begin{array}{l}5.8236 \mathrm{E}- \\
4\end{array}$ & $2.9 \mathrm{E}-5$ & Lognormal & 1.0617 & -9.3916 & \\
\hline & & $\mathrm{CO}$ & $\begin{array}{l}\text { Pearson } 5 \\
\text { (alpha, beta, } \\
\text { gamma) }\end{array}$ & 2.0333 & $\begin{array}{l}3.0057 \mathrm{E}- \\
4\end{array}$ & 0 & & Lognormal & 0.88006 & -8.5539 & \\
\hline & CT & Efficiency & Johnson SB & -0.89523 & 0.60427 & 0.28076 & 0.13344 & Weibull & $\begin{array}{l}1.60 \mathrm{E}+0 \\
8\end{array}$ & $7.03 \mathrm{E}+06$ & $-7.03 E+06$ \\
\hline & & $\mathrm{CO}_{2}$ & Frechet & 1.6757 & 133.6 & 565.66 & & $\begin{array}{l}\text { Exponential } \\
\text { (lambda, } \\
\text { gamma) }\end{array}$ & 0.00523 & 626 & \\
\hline & & $\mathrm{CH}_{4}$ & $\begin{array}{l}\text { Gen. Pareto } \\
\text { (k, sigma, mu) }\end{array}$ & 0.35239 & 0.00514 & 0.02744 & & Weibull & 0.76873 & 0.00894 & 0.02744 \\
\hline & & $\mathrm{N}_{2} \mathrm{O}$ & $\begin{array}{l}\text { Gen. Pareto } \\
(\mathrm{k}, \text { sigma, mu) }\end{array}$ & 0.3446 & 0.00103 & 0.0055 & & Weibull & 0.65721 & 0.00171 & 0.0055 \\
\hline & & $\mathrm{NO}_{\mathrm{x}}$ & Johnson SB & 0.13815 & 0.40494 & 2.967 & 0.89903 & Lognormal & 0.57976 & 0.68013 & \\
\hline & & $\mathrm{SO}_{\mathrm{x}}$ & Inv.Gaussian & 1.2694 & 0.83826 & 0 & & Weibull & 1.2214 & 0.89486 & \\
\hline & & $\mathrm{PM}_{10}$ & $\begin{array}{l}\text { Fatigue Life } \\
\text { (alpha, beta, } \\
\text { gamma) }\end{array}$ & 1.5315 & 0.02977 & 0.23914 & & Gamma & 0.55914 & 0.10226 & 0.24174 \\
\hline & & $\mathrm{PM}_{2.5}$ & Beta & 0.63293 & 4.8745 & 0.04545 & 0.23507 & Gamma & 8.388 & 0.00794 & 0 \\
\hline & & VOC & $\begin{array}{l}\text { Power } \\
\text { Function } \\
\text { (alpha, a, b) }\end{array}$ & 0.18673 & $9.80 \mathrm{E}-05$ & 0.00856 & & Uniform & 0 & 0.00365 & \\
\hline & & $\mathrm{CO}$ & Log-Logistic & 1.597 & 0.00333 & 0.01261 & & Exponential & 212.61 & 0.01297 & \\
\hline & ICE & Efficiency & Dagum & 0.69165 & 28.606 & 0.36016 & 0 & Logistic & 0.01592 & 0.35351 & \\
\hline & & $\mathrm{CO}_{2}$ & Fatigue Life & 0.20375 & 297.52 & 464.38 & & Gamma & 13.771 & 16.815 & 536.52 \\
\hline & & $\mathrm{CH}_{4}$ & Laplace & 488.17 & 0.03288 & & & Lognormal & 0.08116 & -3.4185 & \\
\hline
\end{tabular}


TABLE 20 (Cont.)

\begin{tabular}{|c|c|c|c|c|c|c|c|c|c|c|c|}
\hline \multirow{2}{*}{ Fuel type } & \multirow{2}{*}{$\begin{array}{l}\text { Gener- } \\
\text { ation } \\
\text { Tech- } \\
\text { nology }\end{array}$} & \multirow{2}{*}{$\begin{array}{l}\text { Efficiency, } \\
\text { GHG, } \\
\text { CAP }\end{array}$} & \multicolumn{5}{|c|}{ Best of best } & \multicolumn{4}{|c|}{ Best of eleven } \\
\hline & & & \multicolumn{2}{|l|}{ PDF Type } & \multicolumn{3}{|c|}{ PDF Parameters } & \multirow[t]{2}{*}{ PDF Type } & \multicolumn{3}{|c|}{ PDF Parameters } \\
\hline & & & \multicolumn{8}{|l|}{ (gamma, mu) } & \\
\hline & & $\mathrm{N}_{2} \mathrm{O}$ & Burr & 0.79531 & 33.683 & 0.0079 & -0.00142 & Gamma & 23.837 & $1.10 \mathrm{E}-04$ & 0.00398 \\
\hline & & $\mathrm{NO}_{\mathrm{x}}$ & Frechet & $3.63 E+06$ & $\begin{array}{l}6.84 \mathrm{E}+0 \\
6\end{array}$ & - & & Uniform & 6.0291 & 13.238 & \\
\hline \multirow{14}{*}{ Biomass } & \multirow{14}{*}{ BLR } & $\mathrm{SO}_{\mathrm{x}}$ & Lognormal & 0.23374 & 0.18686 & -0.41726 & & Gamma & 11.602 & 0.08769 & -0.19363 \\
\hline & & $\mathrm{PM}_{10}$ & Cauchy & 0.0038 & 0.07654 & & & Gamma & 1.2247 & 0.07964 & 0 \\
\hline & & $\mathrm{PM}_{2.5}$ & Dagum & 0.37656 & 63.413 & 0.34821 & -0.28986 & Weibull & 4.1231 & 0.07614 & -0.02211 \\
\hline & & VOC & Log-Logistic & $8.43 E+08$ & $\begin{array}{l}3.77 \mathrm{E}+0 \\
6\end{array}$ & 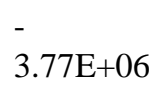 & & Uniform & 0.0044 & 0.03471 & \\
\hline & & $\mathrm{CO}$ & Uniform & 0.00775 & 0.04128 & & & Uniform & 0.00775 & 0.04128 & \\
\hline & & Efficiency & Burr & 2.2266 & 7.0379 & 0.25274 & 0 & Logistic & 0.02502 & 0.2197 & \\
\hline & & $\mathrm{CH}_{4}$ & $\begin{array}{l}\text { Normal } \\
\text { (sigma, mu) }\end{array}$ & 0.10442 & 0.54313 & & & $\begin{array}{l}\text { Normal } \\
\text { (sigma, mu) }\end{array}$ & 0.10442 & 0.54313 & \\
\hline & & $\mathrm{N}_{2} \mathrm{O}$ & Logistic & 0.00769 & 0.07378 & & & Logistic & 0.00769 & 0.07378 & \\
\hline & & $\mathrm{NO}_{\mathrm{x}}$ & Johnson SB & -0.14898 & 0.36949 & 7.6054 & 0.76866 & Uniform & 0.30096 & 9.5998 & \\
\hline & & $\mathrm{SO}_{\mathrm{x}}$ & Uniform & 0 & 28.673 & & & Uniform & 0 & 28.673 & \\
\hline & & $\mathrm{PM}_{10}$ & $\begin{array}{l}\text { Gumbel Min } \\
\text { (sigma, mu) }\end{array}$ & 0.49519 & 3.1532 & & & Weibull & 4.9717 & 3.1168 & \\
\hline & & $\mathrm{PM}_{2.5}$ & Log-Logistic & 12.185 & 2.1766 & 0 & & Gamma & 10.842 & 0.10278 & 1.091 \\
\hline & & VOC & $\begin{array}{l}\text { Hypersecant } \\
\text { (sigma, mu) }\end{array}$ & 0.02764 & 0.13454 & & & Logistic & 0.01524 & 0.13454 & \\
\hline & & $\mathrm{CO}$ & Logistic & 0.49399 & 4.8079 & & & Logistic & 0.49399 & 4.8079 & \\
\hline
\end{tabular}




\subsection{PROJECTION OF GENERATION MIX, EFFICIENCY, COMBUSTION TECHNOLOGY SHARE, AND EMISSION FACTORS}

We use the GHG and CAP emission factors, the efficiencies, and the generation technology share of the EGUs by fuel type that are developed in this work, and the AEO 2011 electricity generation mix, as the baseline update for year 2010 in GREET. For 2015 and 2020, we use AEO 2012's projection of the electricity generation mix to update the generation mix, and we assume incremental improvements in the combustion technology mix based on the relative change rate of our baseline update compared to previous GREET numbers. As a result, an NGCC share of $84.2 \%$ and $87.8 \%$, an NG CT share of $6.1 \%$ and $6.2 \%$, and an IGCC share of $1.0 \%$ and 3.0\% for both coal-fired and biomass-fired EGUs are estimated for 2015 and 2020, respectively, in GREET. An incremental improvement, assumed on the basis of the same rationale, is applied to the efficiencies for years 2015 and 2020, while an incremental decrease in CAP emission factors is assumed for EGUs of various fuel types and generation technologies, except for NGCCs, which are assumed to have constantly low-level CAP emission factors. In addition, for CAP emission factors in the future, the low side of the present PDFs could serve as a much better predictor of future emission performance than the high side or even the average, because the worst performers will be preferentially retired or turned down, mainly as a result of the NSPS mandates and low NG prices.

\subsection{LIFE-CYCLE ENERGY USE, GHG AND CAP EMISSIONS OF SELECTED VEHICLE/FUEL SYSTEMS}

The relative changes in energy use, GHG and CAP emissions per kWh electricity generated for both electricity generation only and the full fuel cycle of the power plant, which are calculated on the basis of the updated GHG and CAP emission factors and energy conversion efficiencies from the present study, are depicted in Figure 2 in comparison with those based on the default parameters of GREET 1_2011. 


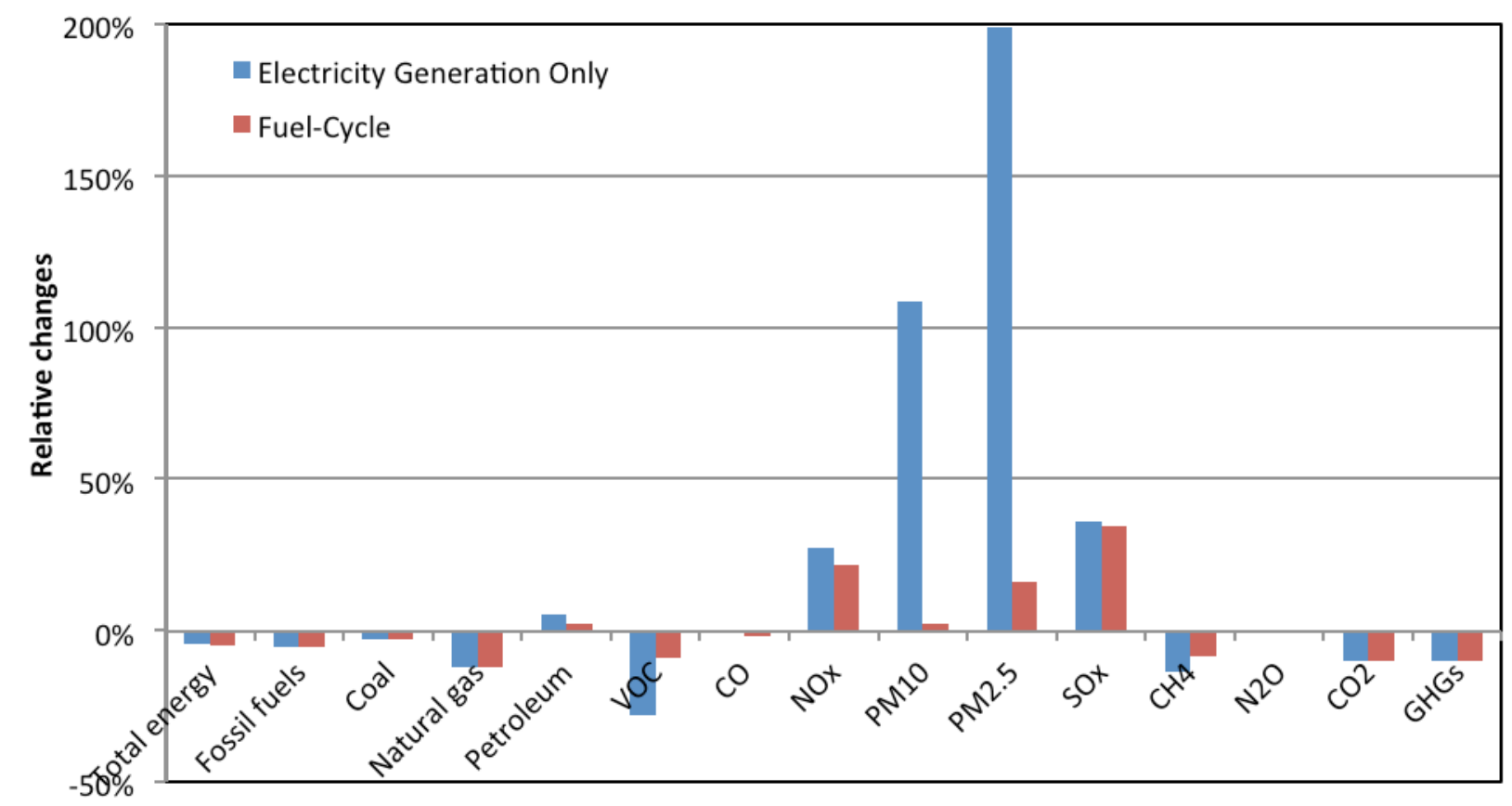

FIGURE 2 Differences in energy use, GHG emissions, and CAP emissions per kWh electricity generated found in the present study, relative to those in GREET 1_2011, for electricity generation only and the full fuel cycle of the power plant.

With the updated characterization of electricity generation in the present study, the total energy use per kWh electricity generated decreases by about $4.6 \%$ and $4.8 \%$, respectively, for electricity generation only and for the total fuel cycle, mostly owing to the significant decrease in NG consumption by about $12 \%$, which is due to the significant increase (from $44.0 \%$ to $79.9 \%$ ) in the share of NGCC, a highly efficient combustion technology. The increase in the use of RFO by about $5.5 \%$ and $2.0 \%$, respectively, for electricity generation only and for the total fuel cycle is mainly due to the decreased efficiency of oil-fired boilers, from 34.8\% in GREET1_2011 to $32.7 \%$ in this study. For nationally averaged total GHG emissions, a significant decrease by about $10.2 \%$ is estimated, primarily owing to the decrease in $\mathrm{CO}_{2}$ emissions by the same magnitude and to the decrease in electricity T\&D losses. CAP emissions have increased by 27.1\%, 108.3\%, 199.0\% and 36.1\% for $\mathrm{PM}_{10}, \mathrm{PM}_{2.5}, \mathrm{SO}_{\mathrm{x}}$ and $\mathrm{NO}_{\mathrm{x}}$, respectively, and decreased by $28.0 \%$ and $1.0 \%$, respectively, for VOC and CO for electricity generation only, and the CAP emissions have increased by $21.7 \%, 2.2 \%, 16.1 \%$, and $34.4 \%$, respectively, for $\mathrm{PM}_{10}, \mathrm{PM}_{2.5}$, $\mathrm{SO}_{\mathrm{x}}$ and $\mathrm{NO}_{\mathrm{x}}$, and decreased by $9.3 \%$ and $2.0 \%$, respectively, for VOC and $\mathrm{CO}$ for the total fuel cycle of electricity generation, which results from the variation in CAP emission factors and efficiencies of various types of power plants. The increased $\mathrm{PM}_{10}, \mathrm{PM}_{2.5}, \mathrm{SO}_{\mathrm{x}}$ and $\mathrm{NO}_{\mathrm{x}}$ emissions will necessitate a reevaluation of the environmental impacts of electricity generation and the application of electrified vehicle technologies. Also, the decreased VOC emissions and increased $\mathrm{NO}_{\mathrm{x}}$ emissions from the power sector could lead to critical reevaluation of the impacts of power 
plants on the occurrence of ozone pollution episodes and the formulation of ozone pollution control strategies, particularly in the so-called $\mathrm{NO}_{\mathrm{x}}$-limited regions for ozone formation.

Using the updated GHG and CAP emission factors, energy conversion efficiencies, and combustion technology shares, life-cycle GHG and CAP emissions of selected vehicle/fuel systems were examined. Furthermore, the uncertainties of both well-to-pump (WTP) and pumpto-wheels (PTW) GHG and CAP emissions were quantified using the updated PDFs, as summarized in Table 20. Figure 3 illustrates the well-to-wheels (WTW) GHG and CAP emissions of selected vehicle/fuel systems, including hybrid electric vehicles (HEVs) and gasoline plug-in HEVs with 40 miles of rated all-electric range (PHEV40), as well as the associated uncertainties. For battery-powered electric vehicles (BEVs), the WTW GHG and CAP emissions produced by recharging with the U.S. grid mix, northeast (NE) grid mix, California (CA) grid mix, and 100\% NGCC electricity are illustrated and compared.

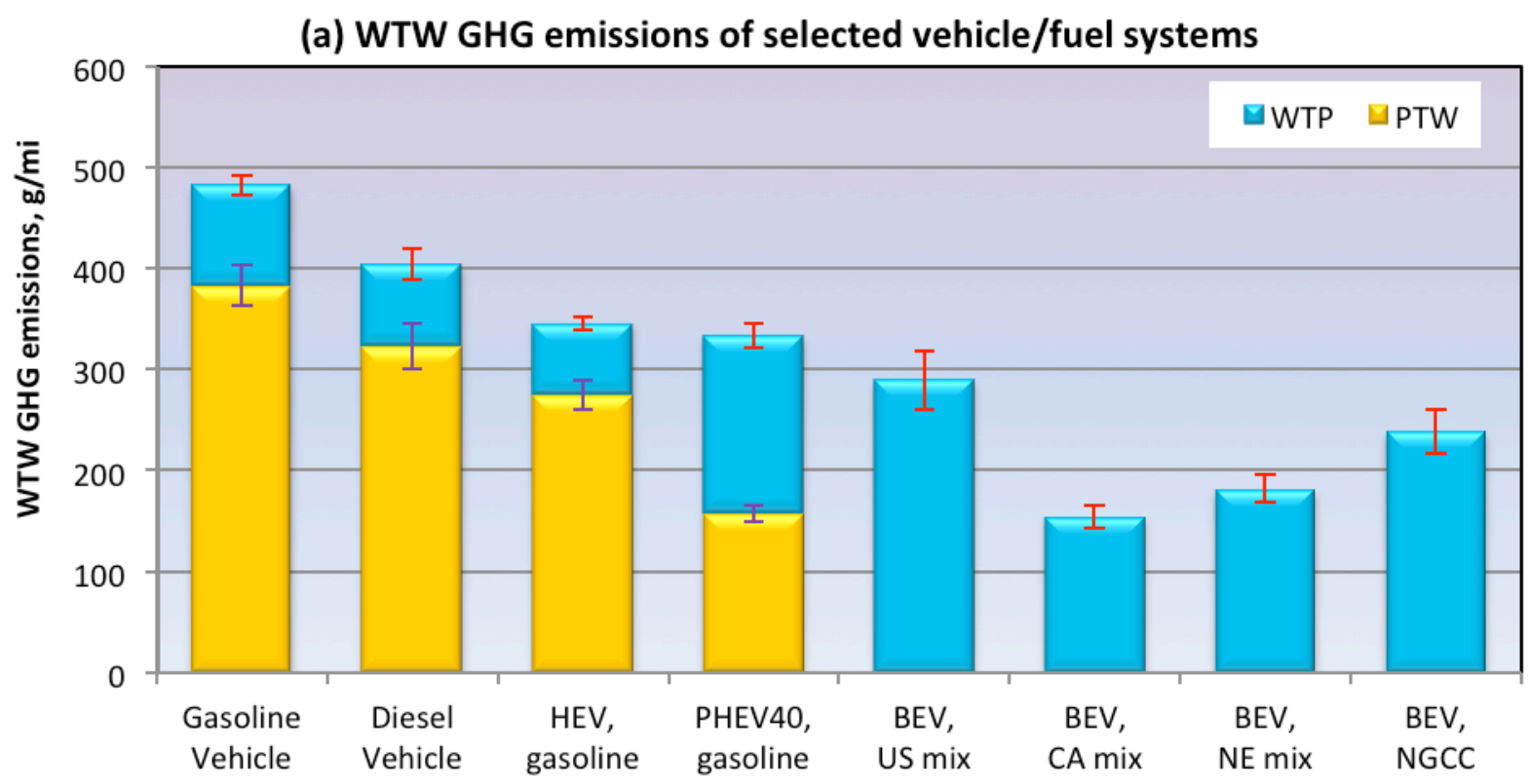


(b) WTW VOC emissions of selected vehicle/fuel systems

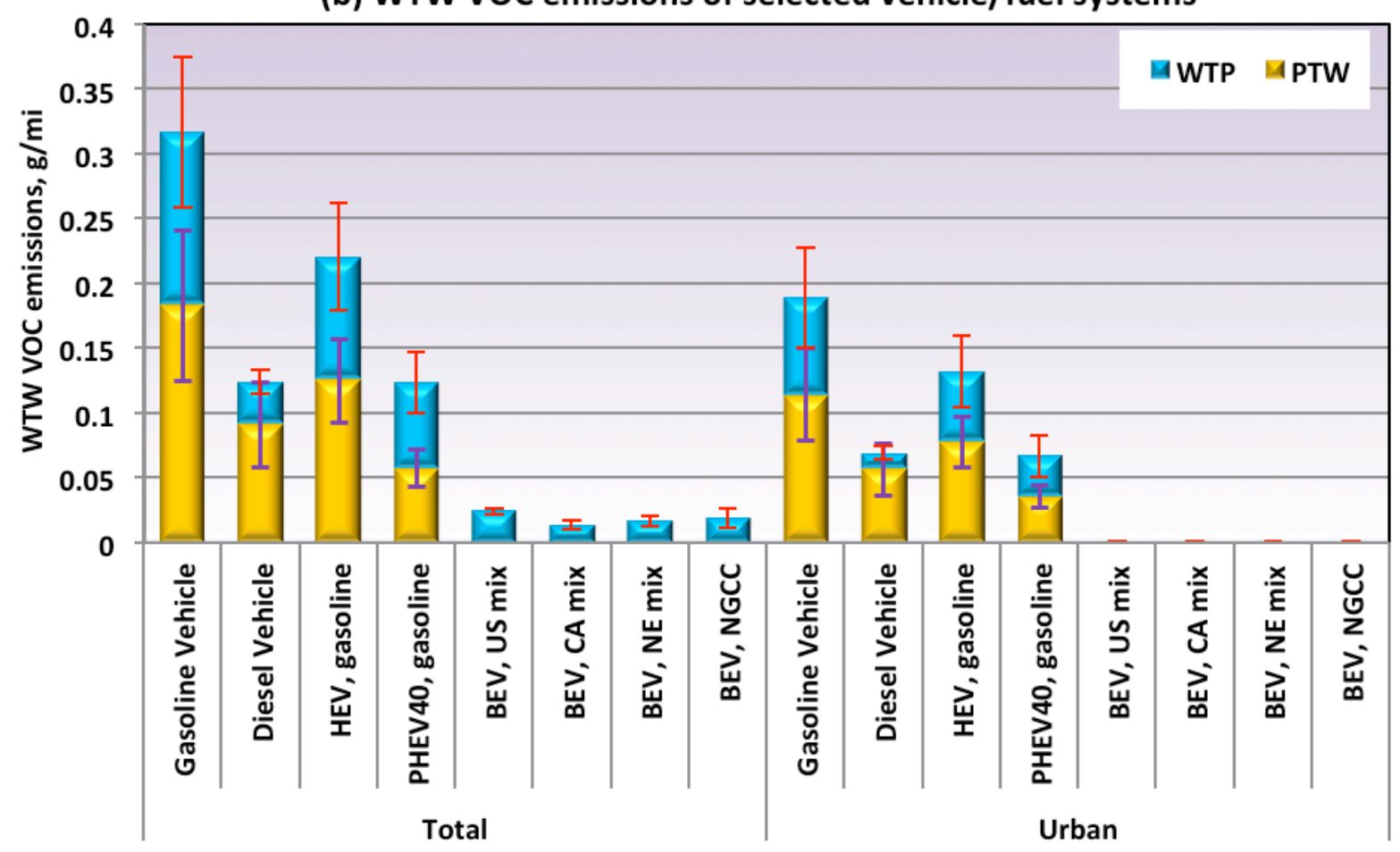

(c) WTW CO emissions of selected vehicle/fuel systems

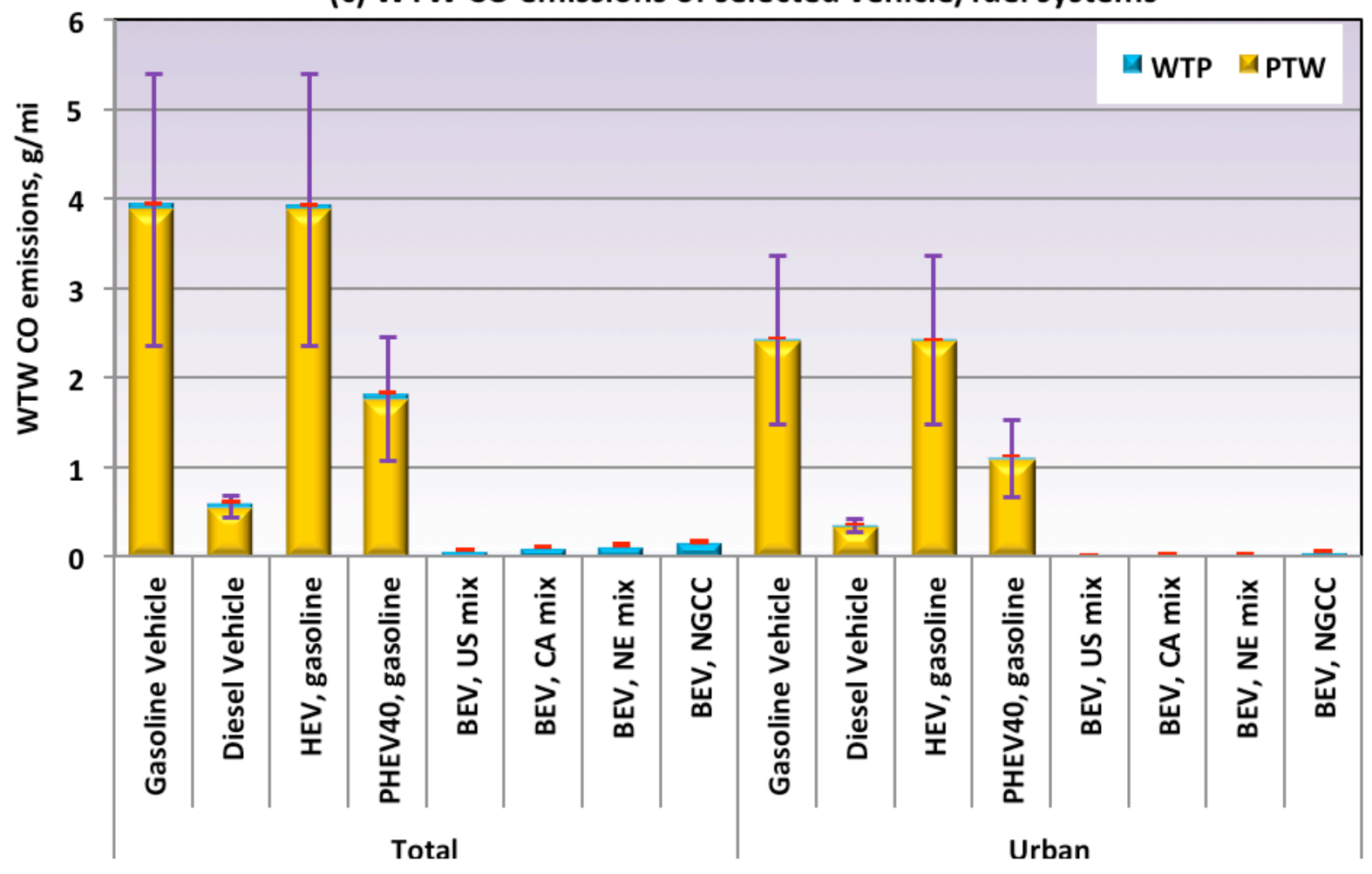



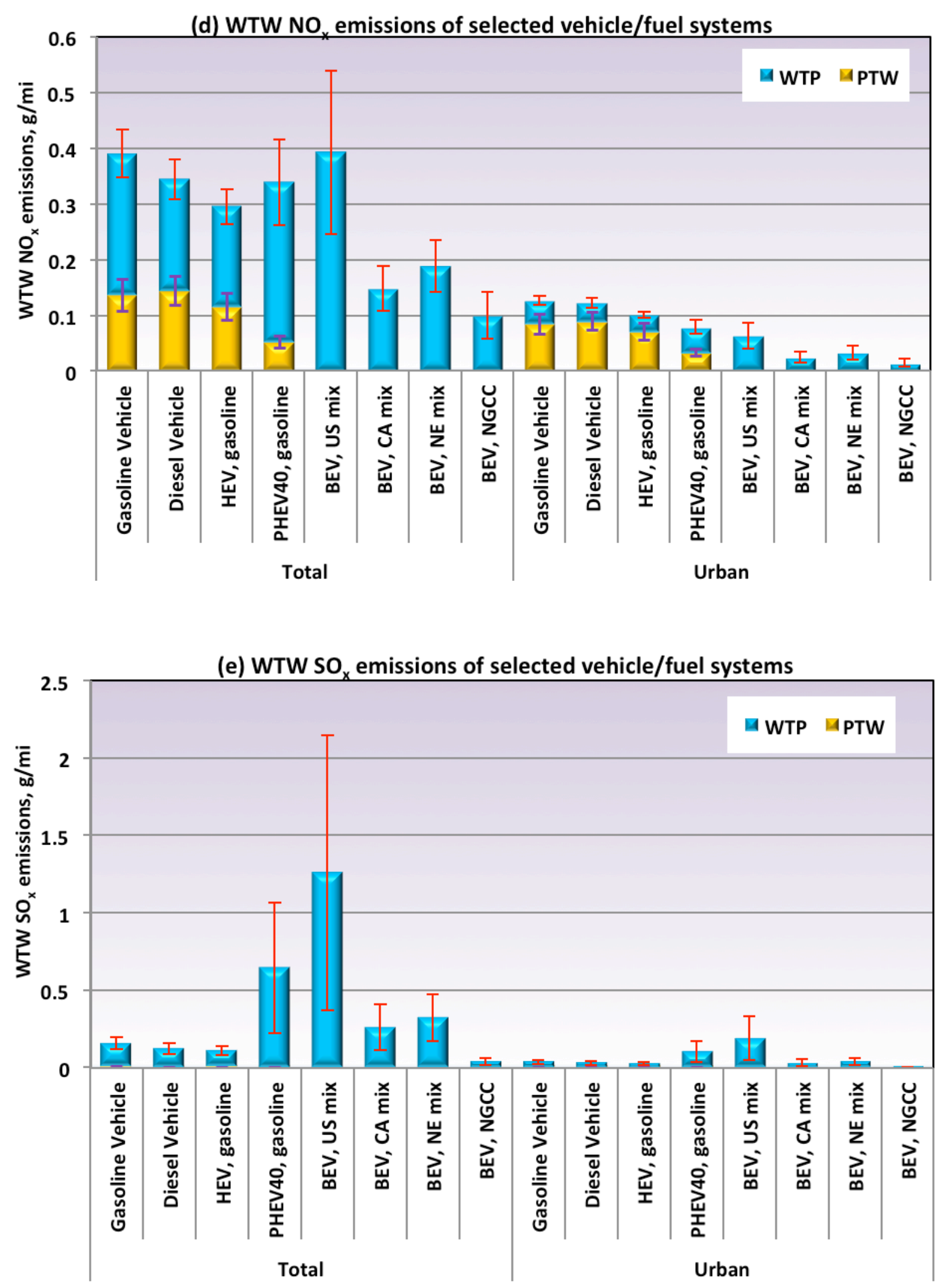

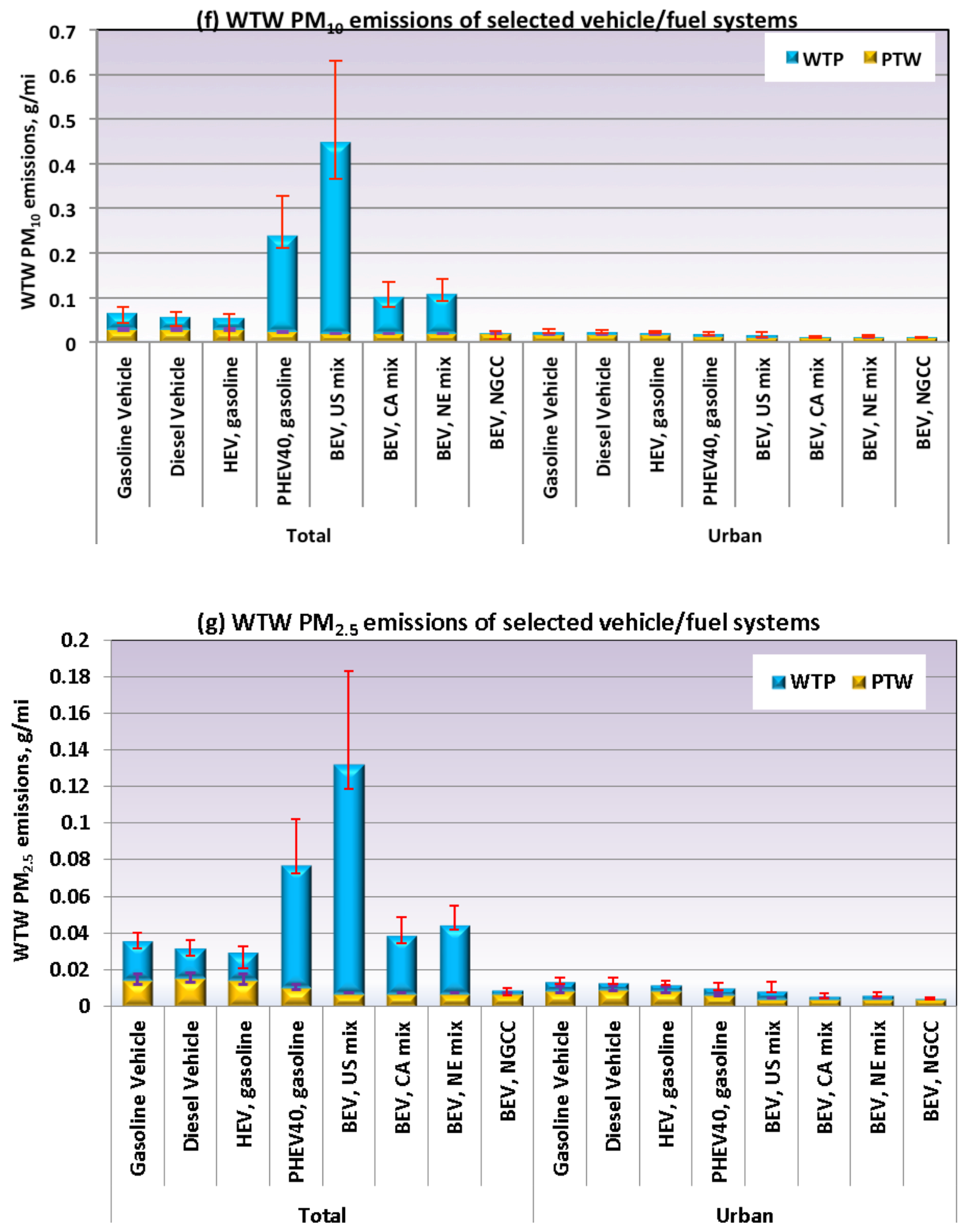

FIGURE 3 Life-cycle (a) GHG; (b) VOC; (c) CO; (d) $\mathrm{NO}_{\mathrm{x}}$; (e) $\mathrm{SO}_{\mathrm{x}}$; (f) $\mathrm{PM}_{10}$; and (g) $\mathbf{P M}_{2.5}$ emissions of selected vehicle/fuel systems with updated characterization of electricity generation module in GREET 1_2011. The red and purple error bars denote the standard deviations of the WTP and PTW emissions based on multiple stochastic simulations. 
Figure 3(a) shows that vehicle/fuel systems like diesel vehicles, gasoline and diesel HEVs, PHEV40S, and BEVs with various grid mixes could achieve different extents of GHG reduction benefits, with the highest reduction potentials of about $68 \%$, $62 \%, 51 \%$ and $34 \%$, respectively, for BEVs with CA grid mix, NE grid mix, NGCC, and the U.S. average grid mix, compared to conventional gasoline vehicles.

Figure 3(b) shows that BEVs with various grid mixes could achieve significant reductions in total VOC emissions, mainly because of the low VOC emissions associated with the WTP stage and avoidance of PTW VOC emissions. Low-sulfur conventional diesel vehicles, gasoline HEVs and gasoline PHEV40 could also achieve considerable reductions in VOC emissions, mainly because of lower WTP and PTW emissions as a result of higher fuel economy and lower tailpipe VOC emission factors, compared to conventional gasoline vehicles. These vehicle/fuel systems could also contribute to reductions in urban VOC emissions, which are precursors of major urban air pollution concerns like ozone formation and fine PM. In addition, moderate to large uncertainties are associated with WTP VOC emissions for most vehicle/fuel systems, particularly for BEVs, indicating that the primary uncertainties are associated with upstream electricity generation.

Figure 3(c) shows that the WTW CO emissions of all the vehicle/fuel systems except for BEVs are dominated by PTW emissions, despite notable uncertainties associated with tailpipe CO emission factors. Meanwhile, diesel vehicles and PHEV40 show remarkable reductions in both total and urban WTW CO emissions, mostly owing to lower tailpipe CO emission factors and higher fuel economy compared to conventional gasoline vehicles.

Figure 3(d) shows that the WTW NO $\mathrm{NO}_{\mathrm{x}}$ emissions for PHEV40 and BEVs are dominated by WTP emissions, while the WTP $\mathrm{NO}_{\mathrm{x}}$ emissions are comparable to the PTW emissions for conventional gasoline and diesel vehicles. In addition, it is possible that gasoline PHEV40s and BEVs will generate more total $\mathrm{NO}_{\mathrm{x}}$ emissions than conventional gasoline and diesel vehicles, mainly because of their high WTP $\mathrm{NO}_{\mathrm{x}}$ emissions from electricity generation. On the other hand, BEVs charged by cleaner generation mixes like the CA and NE mixes, or by electricity from more efficient combustion technologies like NGCC, will doubtless achieve both total and urban WTW $\mathrm{NO}_{\mathrm{x}}$ emission reductions compared to conventional gasoline vehicles. Moreover, BEVs will produces less urban $\mathrm{NO}_{\mathrm{x}}$ emissions, even with the U.S. average electricity generation mix.

As shown in Figure 3(e), WTW $\mathrm{SO}_{\mathrm{x}}$ emissions are dominated by WTP emissions for all vehicle/fuel systems, mainly because of consumption of process fuels like coal, biomass, and residual oil in the fuel production and electricity generation processes. Consequently, BEVs using the current U.S. average electricity generation mix, the CA generation mix, or the NE generation mix are likely to produce more total $\mathrm{SO}_{\mathrm{x}}$ emissions than conventional gasoline and diesel vehicles, while BEVs charged by the U.S. average mix and the NE mix are likely to have slightly higher urban $\mathrm{SO}_{\mathrm{x}}$ emissions, with those charged by the CA mix likely to have slightly lower urban $\mathrm{SO}_{\mathrm{x}}$ emissions, in comparison to conventional gasoline and diesel vehicles. 
Figures 3(f) and 3(g) show that WTP $\mathrm{PM}_{10}$ and $\mathrm{PM}_{2.5}$ emissions are comparable to PTW emissions for conventional gasoline and diesel vehicles and HEVs, while the WTW $\mathrm{PM}_{10}$ and $\mathrm{PM}_{2.5}$ emissions for gasoline PHEV40s and BEVs are dominated by WTP emissions. WTP emissions are also comparable to PTW emissions for conventional gasoline, diesel vehicles, and HEVs, although - particularly for BEVs and PHEV40s - large uncertainties are associated with the WTP $\mathrm{PM}_{10}$ emissions, which are mainly due to the wide range of $\mathrm{PM}_{10}$ and $\mathrm{PM}_{2.5}$ emission factors for EGUs burning coals with diverse ash and sulfur contents and with different deployment rates of PM and sulfur emission control devices. Consequently, gasoline PHEV40s and BEVs charged by the U.S. average electricity generation mix or regional mixes like the CA mix and NE mix are likely to generate more total $\mathrm{PM}_{10}$ emissions than conventional gasoline and diesel vehicles, while BEVs charged by electricity from highly efficient NGCC plants are very likely to produce less total and urban $\mathrm{PM}_{10}$ emissions than conventional gasoline and diesel vehicles. 


\section{REFERENCES}

Bellman, D.K., Blankenship, B.D., Imhoff, C.H., DiPietro, J.P., Rederstorff, B., and Zheng, X.J., 2007. Power Plant Efficiency Outlook. Working Document of the NPC Global Oil \& Gas Study.

Corio, L.A., and Sherwell, J., 2000. In-stack Condensable Particulate Matter Measurement and Permitting Issues for Maryland Power Plants. Journal of Air and Waste Management Association, 50:207-218.

EIA (U.S. Energy Information Administration), 2007a. Form EIA-906, EIA-920, and EIA-923 Data.

EIA, 2007b. Form FERC-423 Data, Monthly Cost and Quality of Fuels for Electric Plants Data.

EIA, 2011. State Electricity Profiles 2010, http://www.eia.gov/electricity/state/. Accessed January 2012.

EVA (Energy Ventures Analysis), 2007. 2007 Operating Performance, Electric Light \& Power Report, http://downloads.pennnet.com/pnet/surveys/elp/elpbinder.pdf. Accessed January 2012.

England, G.C., Wien, S., McGrath, T.P., and Hernandez, D., 2004. Development of Fine Particulate Emission Factors and Speciation Profiles for Oil and Gas-fired Combustion Systems, Topical Report: Test Results for a Combined Cycle Power Plant with Oxidation Catalyst and SCR at Site Echo. Available at http://www.nyserda. ny.gov/en/Publications/Research-and-Development/Environmental/EMEP-Publications/ / media/Files/Publications/Research/Environmental/EMEP/05_Echo_R1-V2.ashx. Accessed June 2012.

EPA, 1995a. Emissions Factors \& AP-42, Chapter 1.1, Bituminous and Subbituminous Coal Combustion, in Compilation of Air Pollutant Emission Factors, Fifth Edition.

EPA, 1995b. Emissions Factors \& AP-42, Chapter 1.7, Lignite Combustion, in Compilation of Air Pollutant Emission Factors, Fifth Edition.

EPA, 1995c. Emissions Factors \& AP-42, Chapter 1.3, Fuel Oil Combustion, in Compilation of Air Pollutant Emission Factors, Fifth Edition.

EPA, 1995d. Emissions Factors \& AP-42, Chapter 1.6, Wood Residue Combustion in Boilers, in Compilation of Air Pollutant Emission Factors, Fifth Edition. 
EPA, 2004. Compilation of Air Pollutant Emission Factors, AP-42-Update 2001 to September 2004.

EPA, 2006. Environmental Footprints and Costs of Coal-Based Integrated Gasification Combined Cycle and Pulverized Coal Technologies, EPA-430/R-06/006, http://www.epa. gov/air/caaac/coaltech/2007_01_epaigcc.pdf. Accessed February 2012.

EPA, 2007a. 2007 Annual, All Programs, Unit-Level Emission Database, http://camddataand maps.epa.gov/gdm/index.cfm?fuseaction=emissions. wizard. Accessed February 2012.

EPA, 2007b. Methodology for Thermal Efficiency and Energy Input Calculations and Analysis of Biomass Cogeneration Unit Characteristics. EPA-HQ-OAR-2007-0012, http://www.epa.gov/ ttn/atw/utility/fnl_biomass_cogen_TSD_04_19_07.pdf. Accessed February 2012.

EPA, 2009a. Steam Electric Power Generating Point Source Category: Final Detailed Study Report, EPA 821-R-09-008, http://water.epa.gov/lawsregs/guidance/cwa/304m/archive/upload/ 2009_10_26_guide_steam_finalreport.pdf. Accessed March 2012.

EPA, 2009b. Inventory of U.S. Greenhouse Gas Emissions and Sinks: 1990-2007, http://www.epa.gov/climatechange/emissions/downloads09/GHG2007entire_report-508.pdf. Accessed March 2012.

EPA, 2009c. Inventory of U.S. Greenhouse Gas Emissions and Sinks: 1990-2007, All Annexes. http://www.epa.gov/climatechange/Downloads/ghgemissions/US_GHG_Inv_Annexes_19902007.pdf. Accessed May 2012.

EPA, 2010a. RACT/BACT/LAER Clearinghouse, Washington, DC, http://cfpub1.epa.gov/ RBLC. Accessed March 2012.

EPA, 2010b. Locating \& Estimating (L\&E) Documents, http://www.epa.gov/ttn/chief/le. Accessed March 2012.

EPA, 2011a. The Emissions \& Generation Resource Integrated Database (eGRID 2010 Version 1.1), http://www.epa.gov/cleanenergy/energy-resources/egrid. Accessed March 2012.

EPA, 2011b. The Internet Version of the Factor Information Retrieval Data System, http://cfpub.epa.gov/webfire/index.cfm?action=fire.main. Accessed March 2012.

EPA, 2011c. Emissions Factors \& AP 42, Compilation of Air Pollutant Emission Factors. Fifth Edition. http://www.epa.gov/ttn/chief/ap42. Accessed September 2011. 
EPA, 2011d. National Emissions Inventory (NEI) Air Pollutant Emissions Trends Data, 1970-2011: Average Annual Emissions, All Criteria Pollutants in MS Excel, www.epa.gov/ttn/ chief/trends/trends06/nationaltier1upto2011basedon2008v1_5.xls. Accessed March 2012.

Farber, P.S., Marmer, D.L., and DePriest, W., 2004. Condensable Particulate Matter: Sources and Control in Coal-Fired Power Plants. Paper Number 17, presented at the 2004 Air \&Waste Management Association Combined Power Plant Control Mega Symposium.

FR (Federal Register), 2007. Revisions to Definition of Cogeneration Unit in Clean Air Interstate Rule (CAIR), CAIR Federal Implementation Plans, Clean Air Mercury Rule (CAMR); and Technical Corrections to CAIR, CAIR FIPs, CAMR, and Acid Rain Program Rules. 59190, Vol 72, No. 202 / Friday, October 19, 2007, http:/www.gpo.gov/fdsys/pkg/FR-2007-1019/pdf/E7-20447.pdf. Accessed December 2011.

Iglewicz, B., and Hoaglin, D., 1993. Volume 16: How to Detect and Handle Outliers, in The ASQC Basic References in Quality Control: Statistical Techniques, E.F. Mykytka, Editor, ASQC Quality Press, Milwaukee, WI.

Ishikawa M., Terauchi, M., Komori, T., and Yasuraoka, J., 2008. Development of High Efficiency Gas Turbine Combined Cycle Power Plant. Mitsubishi Heavy Industries, Ltd., Technical Review Vol. 45 No. 1, http://www.me.metu.edu.tr/courses/me476/downloads/ 476s08ProjectPt4GtTemp.pdf. Accessed November 2011.

Mann, M.K., 2001. A Comparison of the Environmental Consequences of Power from Biomass, Coal, and Natural Gas, http://www.nrel.gov/analysis/forum/pdfs/m_mann.pdf. Accessed September 2011.

NETL (National Energy Technology Laboratory), 2010. Cost and Performance Baseline for Fossil Energy Plants, Volume 1 - Bituminous Coal and Natural Gas to Electricity, DOE/NETL-2010/1397, p. 323.

Pechan, E.H., 2003. Documentation for The 2001 Electric Generating Unit (EGU) Trends Procedures Report, Section 4.2, Pechan \& Associates, Inc., http://www.epa.gov/cair/pdfs/ 2001_EGU_Documentation.pdf, Accessed January 2012.

Pechan, E.H., 2005. Evaluation of Potential $\mathrm{PM}_{2.5}$ Reductions by Improving Performance of Control Devices: $\mathrm{PM}_{2.5}$ Emission Estimates, Final Report, Pechan \& Associates, Inc., http://www.epa.gov/pm/measures/pm25_emission_estimates_2007.pdf. Accessed January 2012. 
Pechan, E.H., 2010a. The Emission \& Generation Resource Integrated Database for 2010 (eGRID2010), Technical Support Document. Pechan Report No. 11.02.001/A319108104, Pechan \& Associates, Inc.

Pechan, E.H., 2010b. Detailed Plan to Develop 2008 EGU Emissions, prepared under Contract No. EP-D-07-097 Work Assignment No. 3-09 for the U.S. Environmental Protection Agency, Research Triangle Park, NC. Pechan \& Associates, Inc.

Rothschild, S., 2012. Personal communication.

Spath, P.L., and Mann, M.K., 2000. Life Cycle Assessment of a Natural Gas Combined-cycle Power Generation System. Report No. NREL/TP-570-27715, National Renewable Energy Laboratory.

Subramanyan, K., and Diwekar, U., 2005. User Manual for Stochastic Simulations. GREET Model Reports. Center for Transportation Research, Energy Systems Division, Argonne National Laboratory, http://www.transportation.anl.gov/pdfs/TA/357.pdf. Accessed January 2012.

U.S. Geological Survey (USGS), 2006. US Coal Quality Database (Version 2.0), National Coal Resources Data System, http://energy.er.usgs.gov/products/databases/CoalQual/index.htm. Accessed April 2012.

Wang, M., 1999. GREET 1.5-Transportation Fuel-Cycle Model, Vol. 1: Methodology, Use, and Results, Report No. ANL/ESD-39, Argonne National Laboratory.

World Bank Group, 1998. Nitrogen Oxides: Pollution Prevention and Control, Pollution Prevention and Abatement Handbook, http://www.ifc.org/ifcext/enviro.nsf/Attachments ByTitle/p_ppah_pguiNitrogenOxidesPollutionControl/\$FILE/HandbookNitrogenOxidesPollutio nPreventionAndControl.pdf. Accessed December 2011. 


\begin{abstract}
APPENDIX
Table and Figure list:

Table A1. $\mathrm{NO}_{\mathrm{x}}$ emission factors of EGUs by fuel type, combustion technology, firing type and emission control technology

Table A2. $\mathrm{SO}_{\mathrm{x}}$ emission factors of EGUs by fuel type, combustion technology, firing type and emission control technology
\end{abstract}

Figure A1. Best-fit cumulative probability distribution functions (CDFs) of electricitygeneration-weighted CDFs of GHG and CAP emission factors for coal-fired boilers.

Figure A2. Best-fit cumulative probability distribution functions (CDFs) of electricitygeneration-weighted CDFs of GHG and CAP emission factors for natural gas-fired boilers.

Figure A3. Best-fit cumulative probability distribution functions (CDFs) of electricitygeneration-weighted CDFs of energy conversion efficiency and GHG and CAP emission factors for natural gas-fired combustion turbines.

Figure A4. Best-fit cumulative probability distribution functions (CDFs) of electricitygeneration-weighted CDFs of GHG and CAP emission factors for natural gas-fired combinedcycle plants.

Figure A5. Best-fit cumulative probability distribution functions (CDFs) of electricitygeneration-weighted CDFs of GHG and CAP emission factors for natural gas-fired internal combustion engines.

Figure A6. Best-fit cumulative probability distribution functions (CDFs) of electricitygeneration-weighted CDFs of GHG and CAP emission factors for oil-fired boilers.

Figure A7. Best-fit cumulative probability distribution functions (CDFs) of electricitygeneration-weighted CDFs of GHG and CAP emission factors for oil-fired combustion turbines.

Figure A8. Best-fit cumulative probability distribution functions (CDFs) of electricitygeneration-weighted CDFs of GHG and CAP emission factors for oil-fired internal combustion engines.

Figure A9. Best-fit cumulative probability distribution functions (CDFs) of electricitygeneration-weighted CDFs of GHG and CAP emission factors for biomass-fired boilers.

Figure A10. Best-fit cumulative probability distribution functions (CDFs) of electricitygeneration-weighted CDFs of energy conversion efficiencies for coal-, natural gas-, oil- and biomass-fired boilers, combustion turbines, combined-cycle plants and internal combustion engines. 


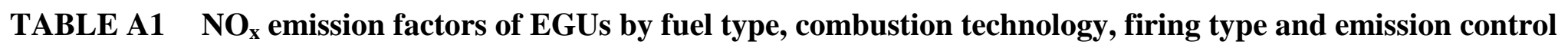
technology

\begin{tabular}{|c|c|c|c|c|c|c|c|c|c|c|c|c|c|c|}
\hline & $\begin{array}{l}\text { Uncon- } \\
\text { trolled }\end{array}$ & LNB & $\begin{array}{l}\text { LNB } \\
\text { w/ } \\
\text { OFA }\end{array}$ & OFA & Reburn & $\begin{array}{c}\text { BOOS, } \\
\text { BF }\end{array}$ & SNCR & SCR & $\begin{array}{c}\text { LNB } \\
\text { w/ } \\
\text { SNCR }\end{array}$ & $\begin{array}{c}\text { LNB } \\
\text { w/ } \\
\text { OFA } \\
\text { and } \\
\text { SCR } \\
\end{array}$ & LEA & FGR & WI & $\begin{array}{l}\text { Com. } \\
\text { Opt. }\end{array}$ \\
\hline \multicolumn{15}{|c|}{ Coal (unit: lb/ton) } \\
\hline $\begin{array}{l}\text { BIT, BLR, } \\
\text { PC, dry } \\
\text { bottom }\end{array}$ & 12 & $\begin{array}{l}(0.55) \\
* 12\end{array}$ & $\begin{array}{l}(0.5)^{*} \\
12\end{array}$ & $\begin{array}{l}(0.75) \\
* 12\end{array}$ & $\begin{array}{l}(0.45)^{*} \\
12\end{array}$ & $\begin{array}{l}(0.85)^{*} \\
12\end{array}$ & $\begin{array}{l}(0.55)^{*} \\
12\end{array}$ & $\begin{array}{l}(0.2)^{*} \\
12\end{array}$ & $\begin{array}{l}(0.35)^{*} \\
12\end{array}$ & $\begin{array}{l}(0.1)^{*} \\
12\end{array}$ & $\begin{array}{l}\left(0.8^{\mathrm{a}}\right) \\
* 12\end{array}$ & $\begin{array}{l}\left(0.65^{\mathrm{a}}\right) \\
* 12\end{array}$ & $\begin{array}{l}\left(0.7^{\mathrm{a}}\right) \\
* 12\end{array}$ & \\
\hline $\begin{array}{l}\text { BIT, BLR, } \\
\text { PC, wet } \\
\text { bottom }\end{array}$ & 31 & & & & & & & & & & & & & \\
\hline $\begin{array}{l}\text { BIT, BLR, } \\
\text { tangential }\end{array}$ & 10 & 9.7 & & & & & & & & & & & 7 & 8 \\
\hline BIT, FBC & 15.2 & & & & & & & & & & & & & \\
\hline $\begin{array}{l}\text { BIT, } \\
\text { Stoker }\end{array}$ & 11 & & & & & & & & & & & & & \\
\hline $\begin{array}{l}\text { BIT, } \\
\text { Cyclone }\end{array}$ & 33 & & & & & & & & & & & & & \\
\hline $\begin{array}{l}\text { SUB, } \\
\text { BLR, PC, } \\
\text { dry bottom }\end{array}$ & 7.4 & & & & & & & & & & & & & \\
\hline $\begin{array}{l}\text { SUB, } \\
\text { BLR, PC, } \\
\text { wet bottom }\end{array}$ & 24 & & & & & & & & & & & & & \\
\hline $\begin{array}{l}\text { SUB, } \\
\text { BLR, } \\
\text { tangential }\end{array}$ & 7.2 & & & & & & & & & & & & & \\
\hline SUB, FBC & 15.2 & & & & & & & & & & & & & \\
\hline $\begin{array}{l}\text { SUB, } \\
\text { Stoker }\end{array}$ & 8.8 & & & & & & & & & & & & & \\
\hline $\begin{array}{l}\text { SUB, } \\
\text { Cyclone }\end{array}$ & 17 & & & & & & & & & & & & & \\
\hline
\end{tabular}


TABLE A1 (Cont.)

\begin{tabular}{|c|c|c|c|c|c|c|c|c|c|c|c|c|c|c|}
\hline & $\begin{array}{l}\text { Uncon- } \\
\text { trolled }\end{array}$ & LNB & $\begin{array}{c}\text { LNB } \\
\text { W/ } \\
\text { OFA }\end{array}$ & OFA & Reburn & $\begin{array}{c}\text { BOOS, } \\
\text { BF }\end{array}$ & SNCR & SCR & $\begin{array}{c}\text { LNB } \\
\text { W/ } \\
\text { SNCR }\end{array}$ & $\begin{array}{c}\text { LNB } \\
\text { w/ } \\
\text { OFA } \\
\text { and } \\
\text { SCR }\end{array}$ & LEA & FGR & WI & $\begin{array}{l}\text { Com. } \\
\text { Opt. }\end{array}$ \\
\hline \multicolumn{15}{|c|}{ Coal (unit: lb/ton) } \\
\hline SUB, Cell & 14 & & & & & & & & & & & & & \\
\hline $\begin{array}{l}\text { LIG, BLR, } \\
\text { PC, dry } \\
\text { bottom }\end{array}$ & 6.3 & 4.6 & & 4.6 & & & & & & & & & & \\
\hline $\begin{array}{l}\text { LIG, BLR, } \\
\text { tangential }\end{array}$ & 7.1 & & & 6 & & & & & & & & & & \\
\hline $\begin{array}{l}\text { LIG, } \\
\text { Cyclone }\end{array}$ & 15 & & & & & & & & & & & & & \\
\hline LIG, FBC & 3.6 & & & & & & & & & & & & & \\
\hline $\begin{array}{l}\text { PetCoke, } \\
\text { BLR }\end{array}$ & 21 & & & & & & & & & & & & & \\
\hline \multicolumn{15}{|c|}{ NG (unit: lb/million scf) } \\
\hline NG, BLR & $\begin{array}{l}190^{\mathrm{b}} ; \\
100^{\mathrm{c}}\end{array}$ & $\begin{array}{l}140^{\mathrm{b}} ; \\
32^{\mathrm{c}}\end{array}$ & & & & & & & & & & $\begin{array}{l}100^{\mathrm{b}} ; \\
32^{\mathrm{c}}\end{array}$ & & \\
\hline $\begin{array}{l}\text { NG, BLR } \\
\text { (tangen- } \\
\text { tial) }\end{array}$ & 170 & & & & & & & & & & & 76 & & \\
\hline NG, ICE & 2840 & & & & & & & & & & & & & \\
\hline NG, CT & 0.32 & & & & & & & & & & & & 0.13 & 0.099 \\
\hline LFG, $\mathrm{CT}^{\mathrm{d}}$ & 0.14 & & & & & & & & & & & & & \\
\hline BFG, BLR & 23 & & & & & & & & & & & & & \\
\hline $\mathrm{DG}, \mathrm{CT}^{\mathrm{d}}$ & 0.16 & & & & & & & & & & & & & \\
\hline \multicolumn{15}{|c|}{ Oil (unit: lb/1000 gal) } \\
\hline RFO, BLR & $47^{\mathrm{e}} ; 32^{\mathrm{f}}$ & $\begin{array}{l}40^{\mathrm{e}} ; \\
26^{\mathrm{f}}\end{array}$ & & & & & & & & & & & & \\
\hline DFO, BLR & 24 & 10 & & & & & & & & & & 10 & & \\
\hline
\end{tabular}


TABLE A1 (Cont.)

\begin{tabular}{|c|c|c|c|c|c|c|c|c|c|c|c|c|c|c|}
\hline & $\begin{array}{l}\text { Uncon- } \\
\text { trolled }\end{array}$ & LNB & $\begin{array}{c}\text { LNB } \\
\text { w/ } \\
\text { OFA }\end{array}$ & OFA & Reburn & $\begin{array}{c}\text { BOOS, } \\
\text { BF }\end{array}$ & SNCR & SCR & $\begin{array}{c}\text { LNB } \\
\text { w/ } \\
\text { SNCR } \\
\end{array}$ & $\begin{array}{l}\text { LNB } \\
\text { w/ } \\
\text { OFA } \\
\text { and } \\
\text { SCR }\end{array}$ & LEA & FGR & WI & $\begin{array}{c}\text { Com. } \\
\text { Opt. }\end{array}$ \\
\hline \multicolumn{15}{|c|}{ Oil (unit: lb/1000 gal) } \\
\hline DFO, CT & $0.88^{\mathrm{d}}$ & & & & & & & & & & & & $0.24^{\mathrm{d}}$ & \\
\hline DFO, ICE & 604 & & & & & & & & & & & & & \\
\hline JF, CT & $0.88^{\mathrm{d}}$ & & & & & & & & & & & & & \\
\hline KER, CT & $0.88^{\mathrm{d}}$ & & & & & & & & & & & & & \\
\hline WO, BLR & 19 & & & & & & & & & & & & & \\
\hline \multicolumn{15}{|c|}{ Biomass (lb/mmBtu) } \\
\hline $\begin{array}{l}\text { Dry WDS, } \\
\text { BLR, } \\
\leq 20 \% \\
\text { moisture }\end{array}$ & 0.49 & & & & & & & & & & & & & \\
\hline $\begin{array}{l}\text { Wet WDS, } \\
\text { BLR, } \\
\geq 20 \% \\
\text { moisture }\end{array}$ & 0.22 & & & & & & & & & & & & & \\
\hline BLQ, BLR & & & & & & & & & & & & $0.209^{\mathrm{g}}$ & & \\
\hline
\end{tabular}

Notes: $\quad$ BOOS is burners-out-of-service.

$\mathrm{BF}$ is biased firing.

SCR is selective catalytic reduction.

SNCR is selective noncatalytic reduction.

LEA is low excess air.

Com.Opt. is combustion optimization.

The numbers in parentheses indicate the emission reduction ratio achieved by the corresponding emission control device in operation, obtained mainly from AP-42 on an average basis. 


\section{TABLE A1 (Cont.)}

Source: World Bank Group, 1998.

For boilers $>100$ million Btu/hr.

For boilers $<100$ million Btu/hr.

Unit is $\mathrm{lb} / \mathrm{mmBtu}$.

Normal firing boilers.

Tangential firing boilers.

g Unit is lb/ton. 
TABLE A2 SO $\mathrm{SO}_{\mathrm{x}}$ emission factors of EGUs by fuel type, combustion technology, firing type and emission control technology

\begin{tabular}{|c|c|c|c|c|c|}
\hline & Uncontrolled & Wet scrubber & Spray drying & Furnace injection & Duct injection \\
\hline \multicolumn{6}{|c|}{ Coal (unit: lb/ton) } \\
\hline BIT, BLR, PC, dry bottom & $38 * S$ & $0.1 * 38 * S$ & $0.2 * 38 * \mathrm{~S}$ & $0.625 * 38 * S$ & $0.625 * 38 * S$ \\
\hline BIT, BLR, PC, wet bottom & $38 * S$ & & & & \\
\hline BIT, BLR, tangential & $38 * S$ & & & & \\
\hline BIT, FBC & $38 * S$ & & & & \\
\hline BIT, Stoker & $38 * S$ & & & & \\
\hline BIT, Cyclone & $38 * S$ & & & & \\
\hline SUB, BLR, PC, dry bottom & $35 * \mathrm{~S}$ & & & & \\
\hline SUB, BLR, PC, wet bottom & $35 * S$ & & & & \\
\hline SUB, BLR, tangential & $35 * S$ & & & & \\
\hline SUB, FBC & $35 * \mathrm{~S}$ & & & & \\
\hline SUB, Stoker & $35 * \mathrm{~S}$ & & & & \\
\hline SUB, Cyclone furnace & $35 * \mathrm{~S}$ & & & & \\
\hline SUB, Cell & $35 * S$ & & & & \\
\hline LIG, BLR, PC, dry bottom & $38 * S$ & & & & \\
\hline LIG, BLR, tangential & $38 * S$ & & & & \\
\hline LIG, BLR, Cyclone & $38 * S$ & & & & \\
\hline LIG, FBC & $38 * S$ & & & & \\
\hline PetCoke, BLR & $39 * S$ & & & & \\
\hline \multicolumn{6}{|c|}{ NG (unit: lb/million scf) } \\
\hline NG, BLR & 0.6 & & & & \\
\hline NG, BLR (tangential) & 0.6 & & & & \\
\hline NG, ICE & 0.6 & & & & \\
\hline NG, CT & $0.94 * S$ & & & & \\
\hline
\end{tabular}


TABLE A2 (Cont.)

\begin{tabular}{|c|c|c|c|c|c|}
\hline & Uncontrolled & Wet scrubber & Spray drying & Furnace injection & Duct injection \\
\hline \multicolumn{6}{|c|}{ NG (unit: lb/million scf) } \\
\hline $\mathrm{LFG}, \mathrm{CT}^{\mathrm{a}}$ & 0.045 & & & & \\
\hline BFG & $950 * S$ & & & & \\
\hline DG, BLR & 4.5 & & & & \\
\hline \multicolumn{6}{|c|}{ Oil (unit: lb/1000 gal) } \\
\hline RFO, BLR & $157 * \mathrm{~S}$ & & & & \\
\hline DFO, BLR & $142 * S$ & & & & \\
\hline $\mathrm{DFO}, \mathrm{CT}$ & $140.39 * \mathrm{~S}$ & & & & \\
\hline DFO, ICE & 0.29 & & & & \\
\hline JF, CT & $1.01 * \mathrm{~S}$ & & & & \\
\hline $\mathrm{KER}, \mathrm{CT}^{\mathrm{a}}$ & $1.01 * \mathrm{~S}$ & & & & \\
\hline WO, BLR & $147 * S$ & & & & \\
\hline \multicolumn{6}{|c|}{ Biomass (unit: lb/mmBtu) } \\
\hline Dry WDS, BLR, $\leq 20 \%$ moisture & 0.025 & & & & \\
\hline Wet WDS, BLR, $\geq 20 \%$ moisture & 0.025 & & & & \\
\hline BLQ, BLR & & $0.000804^{\mathrm{b}}$ & & & \\
\hline
\end{tabular}

a Unit is lb per mmBtu;

b Unit is lb per ton. 
The following figures give cumulative probability distributions (CDFs) of PDFs developed for energy conversion efficiencies and GHG and CAP emission factors of coal-, natural gas-, oiland biomass-fired boilers, combustion turbines, combined-cycle, and internal combustion engines for U.S. EGUs.
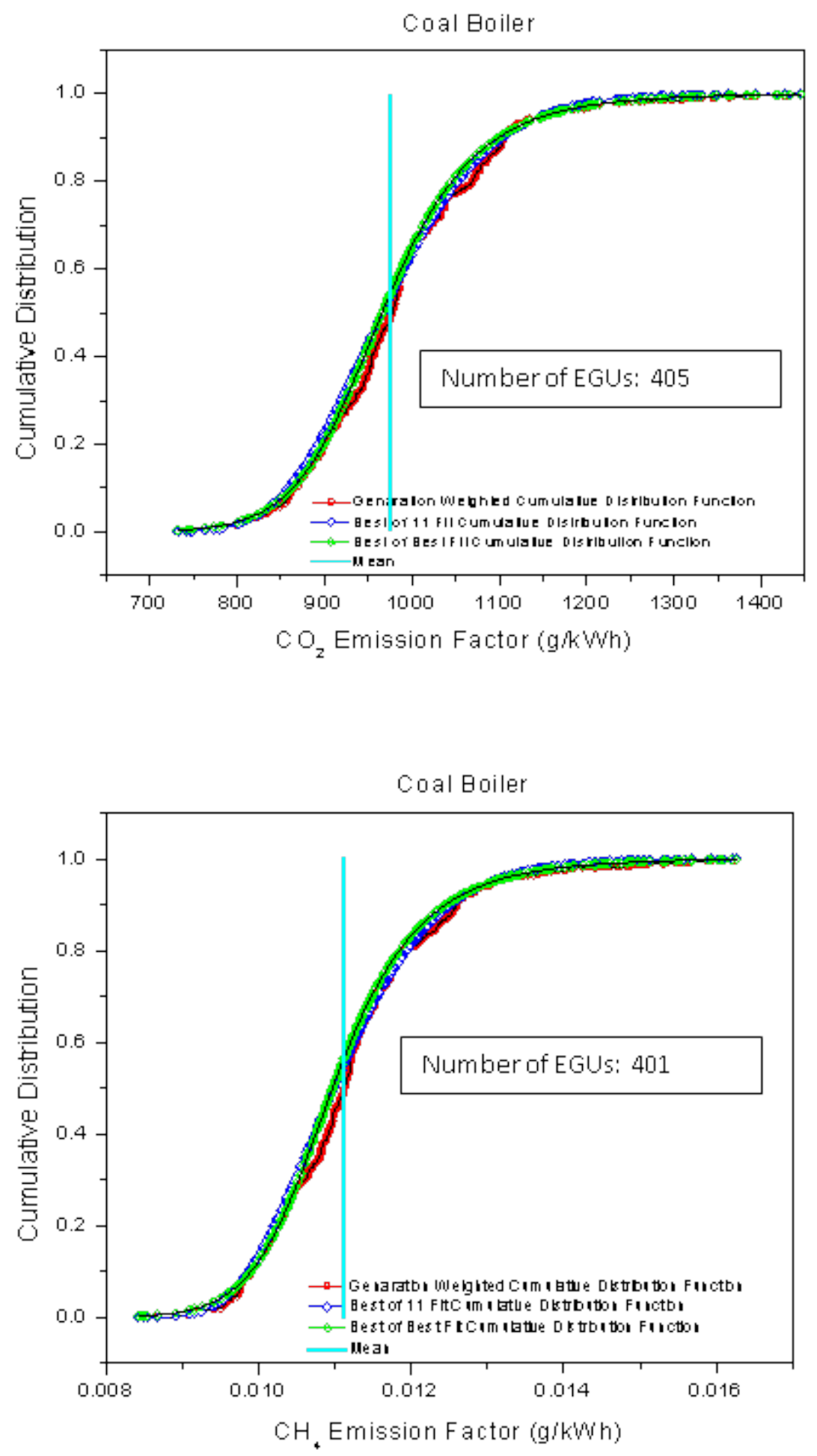

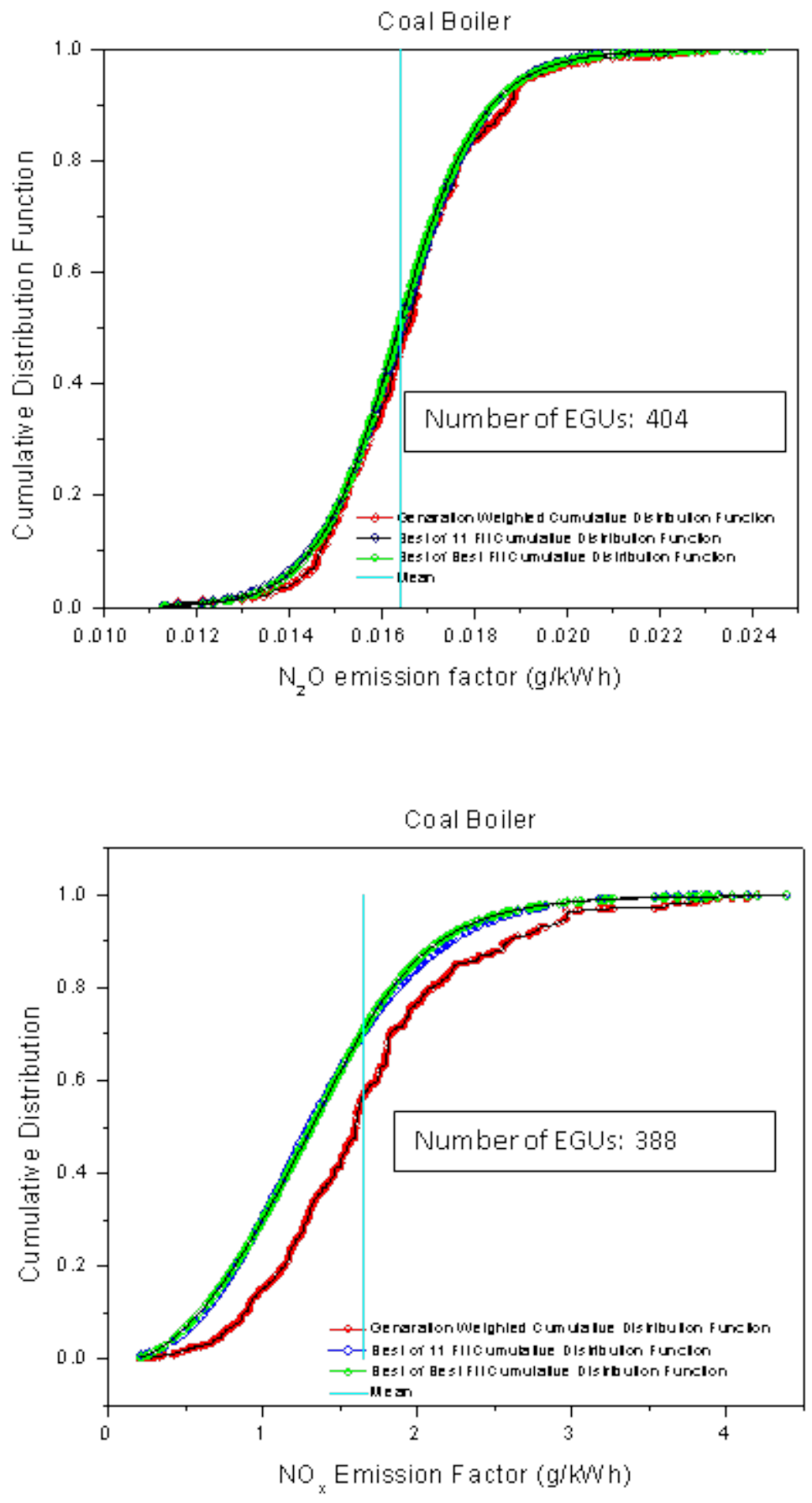

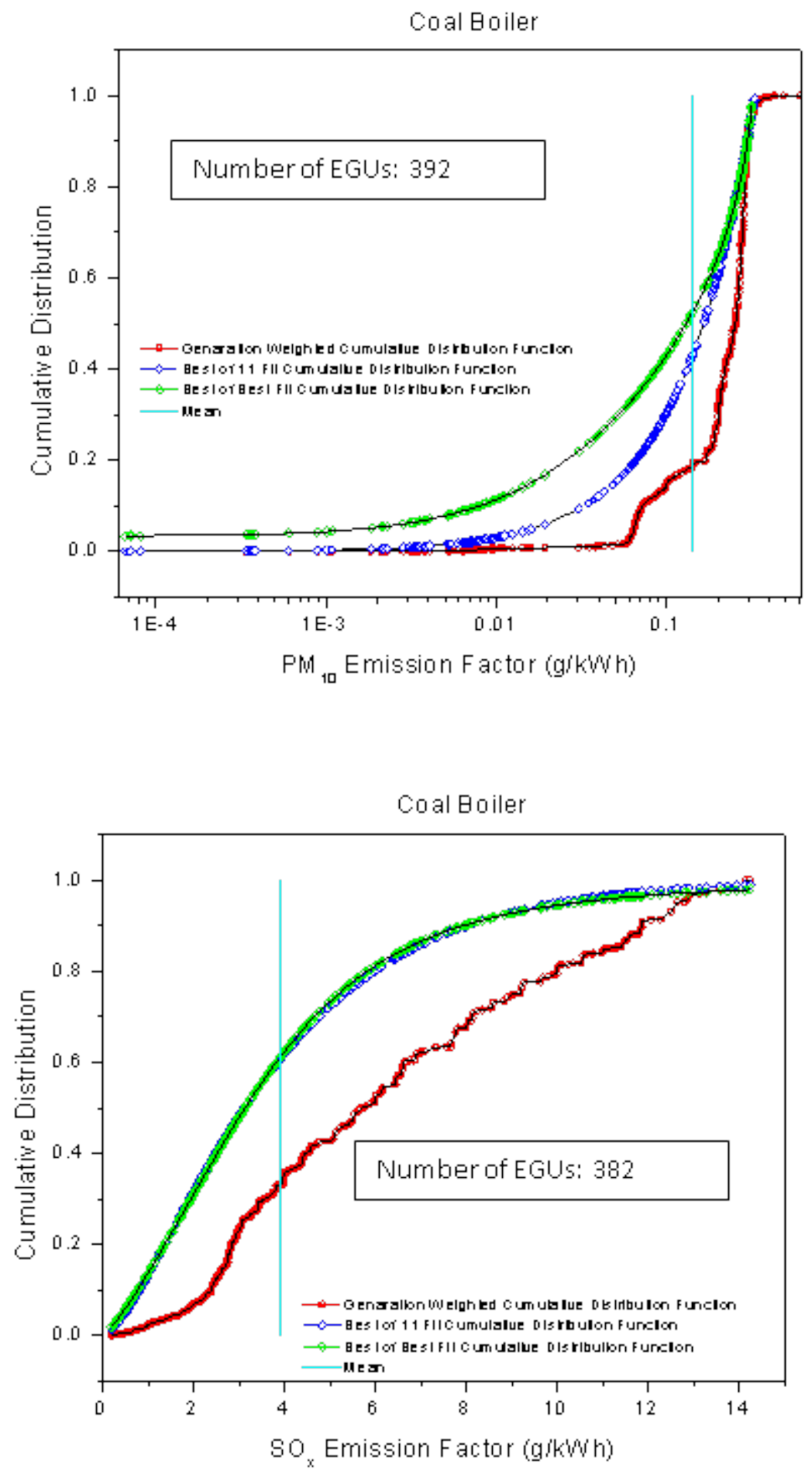

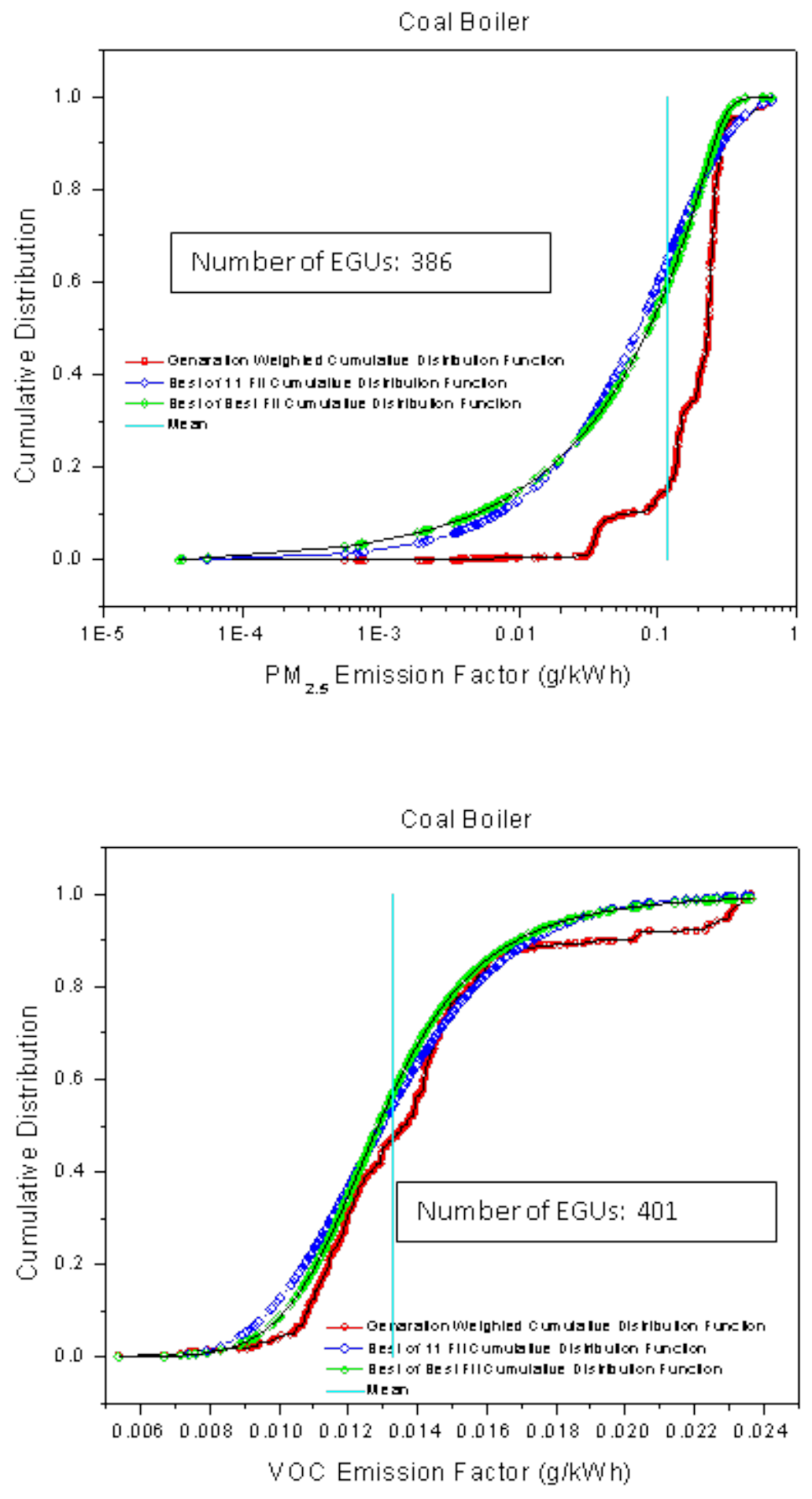


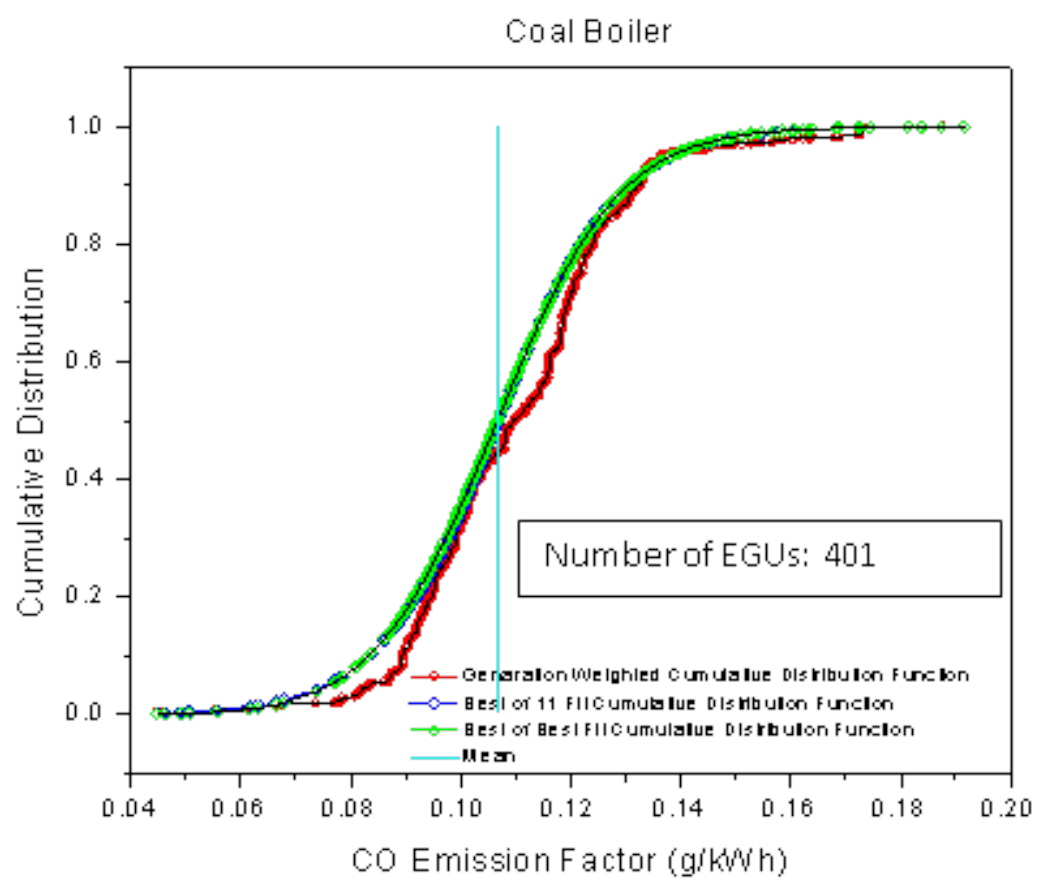

\section{FIGURE A1 Best-fit CDFs of electricity-generation- weighted GHG and CAP emission factors for coal-fired boilers.}

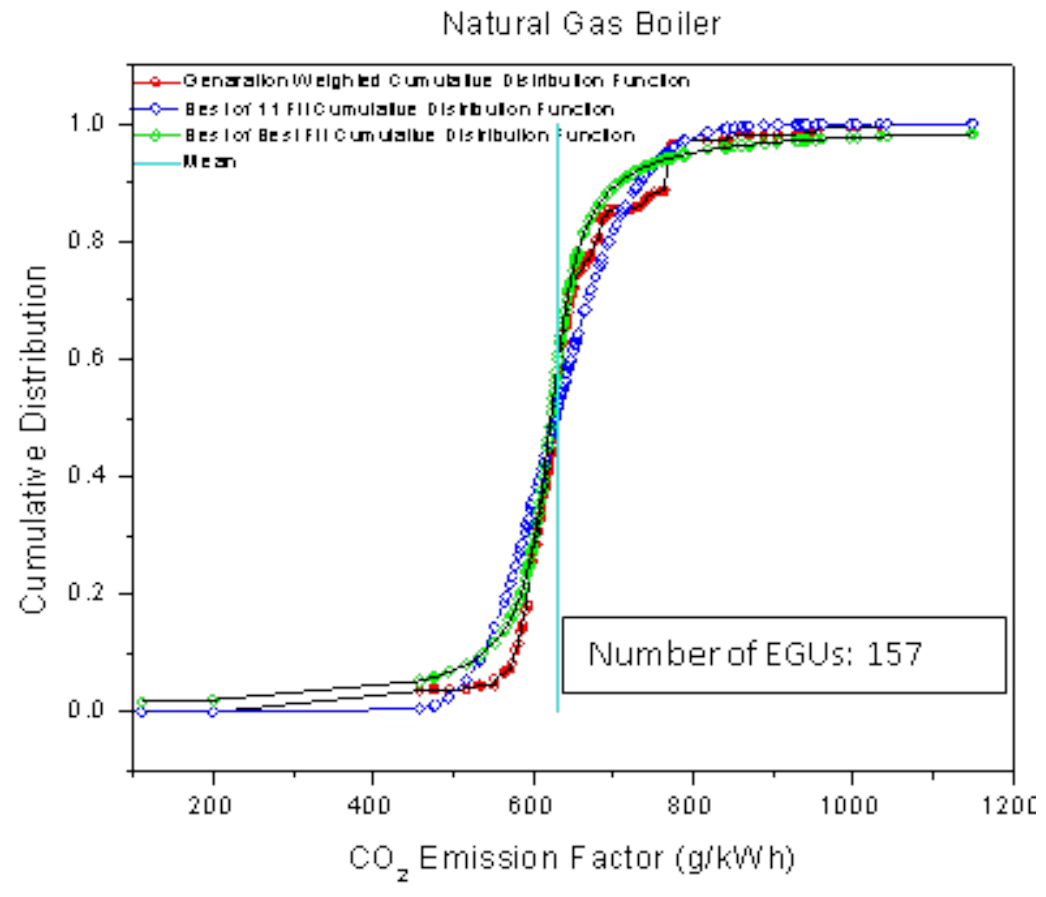



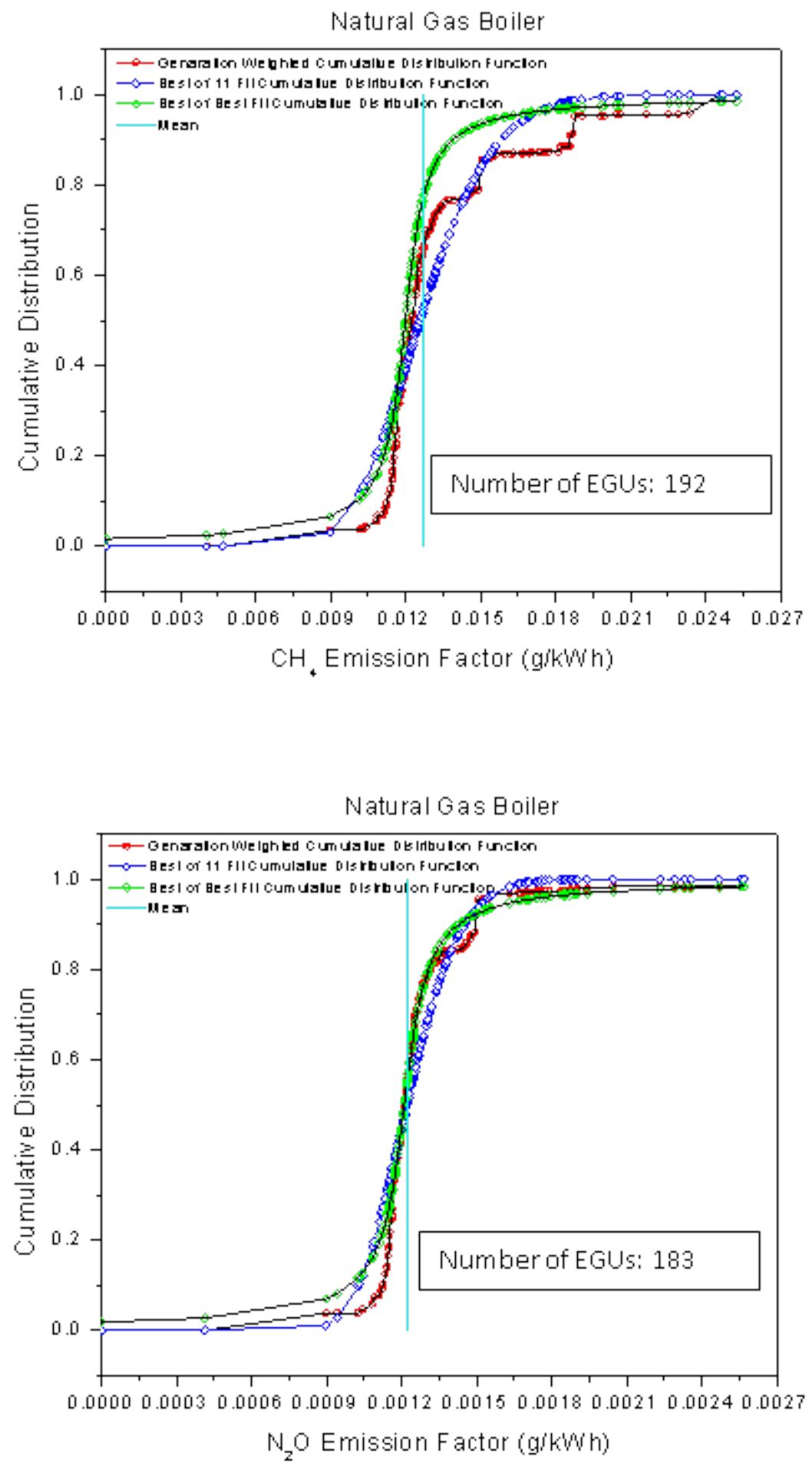

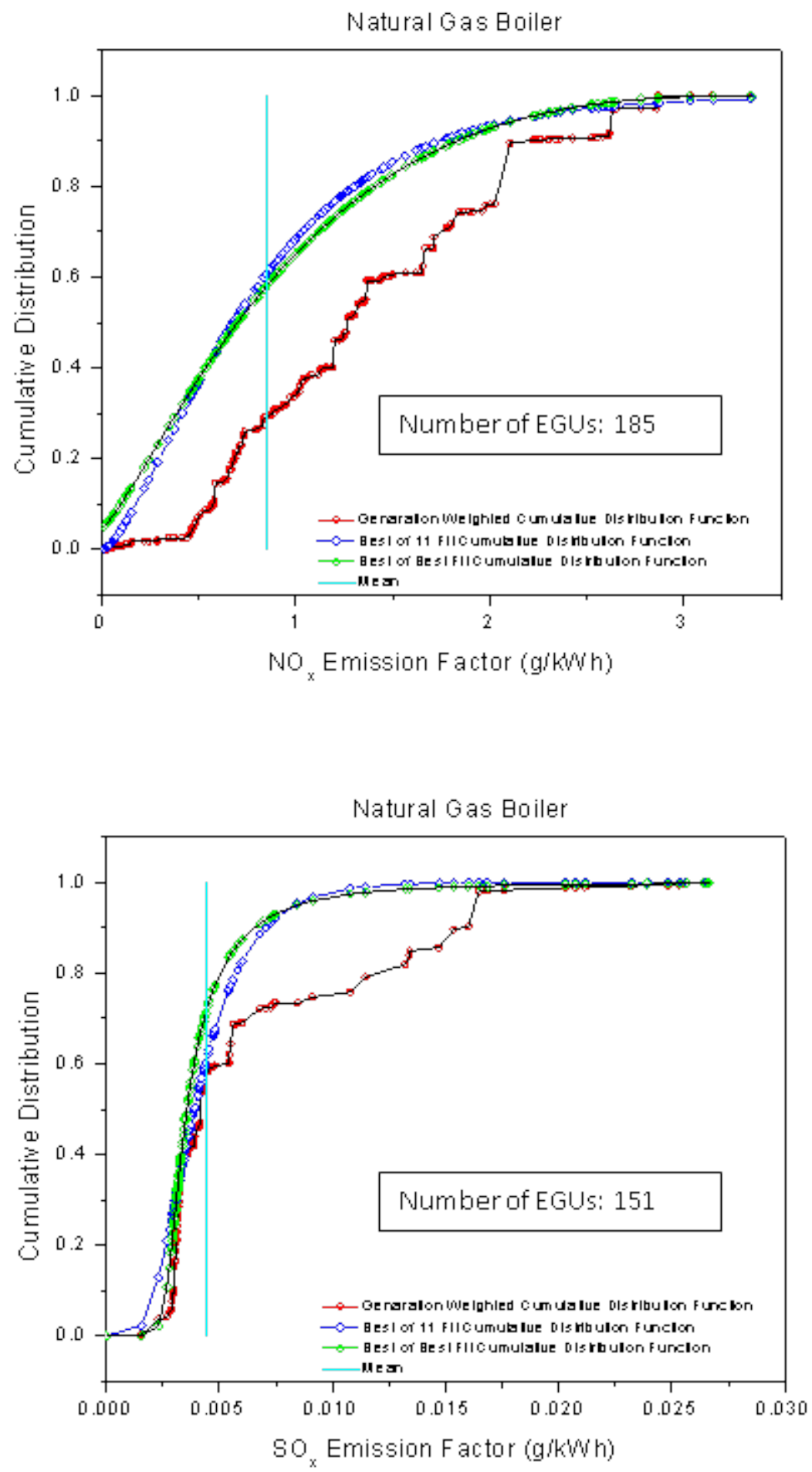

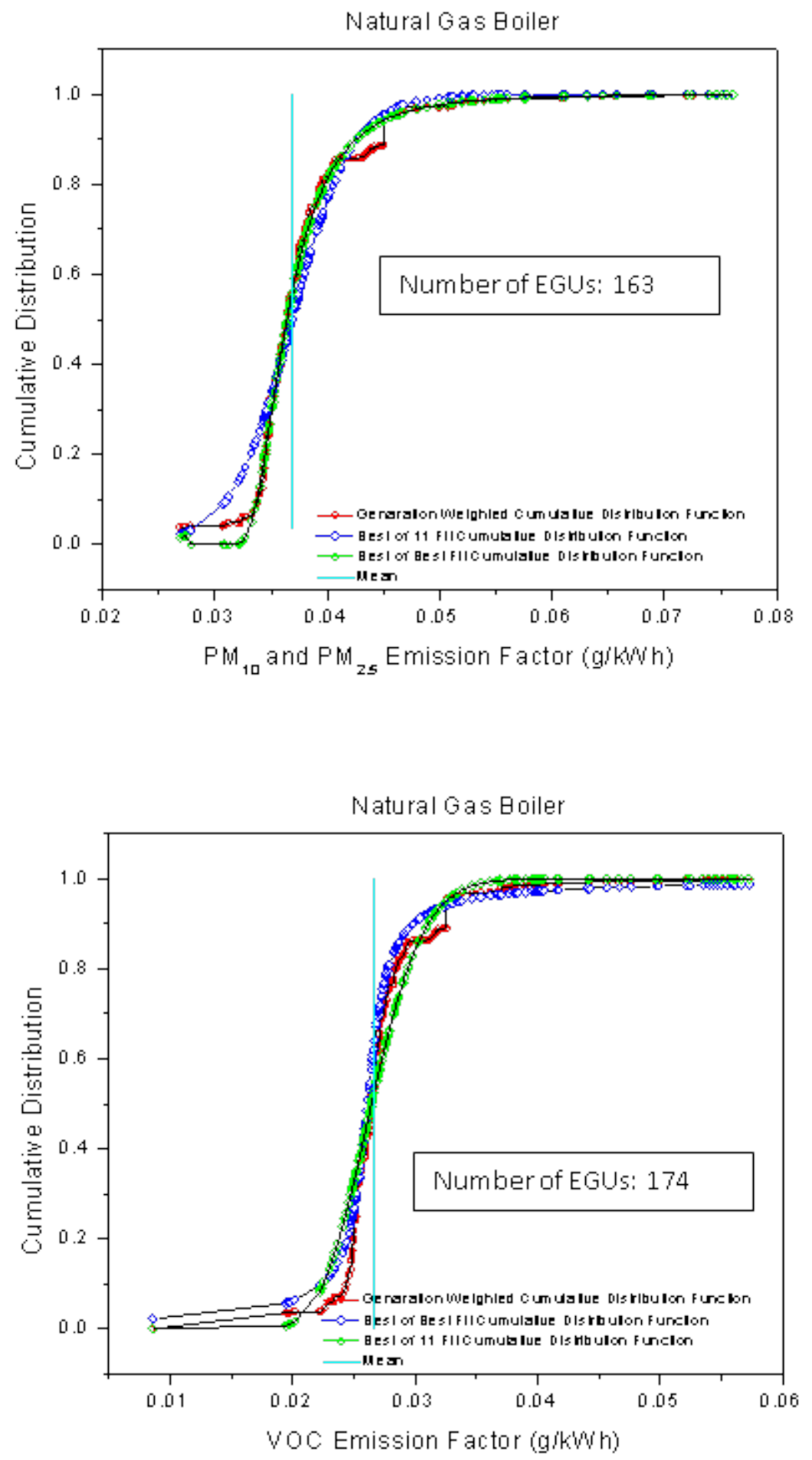
Natural Gas Boiler

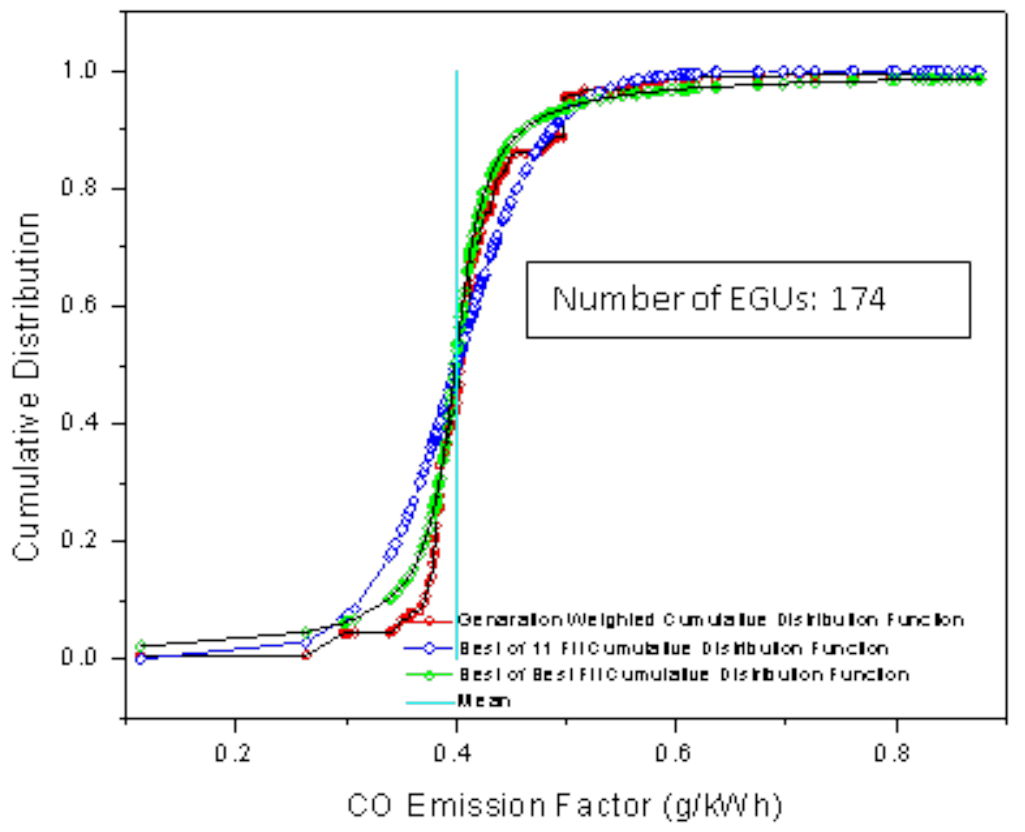

FIGURE A2 Best-fit CDFs of electricity-generationweighted GHG and CAP emission factors for natural gas-fired boilers.

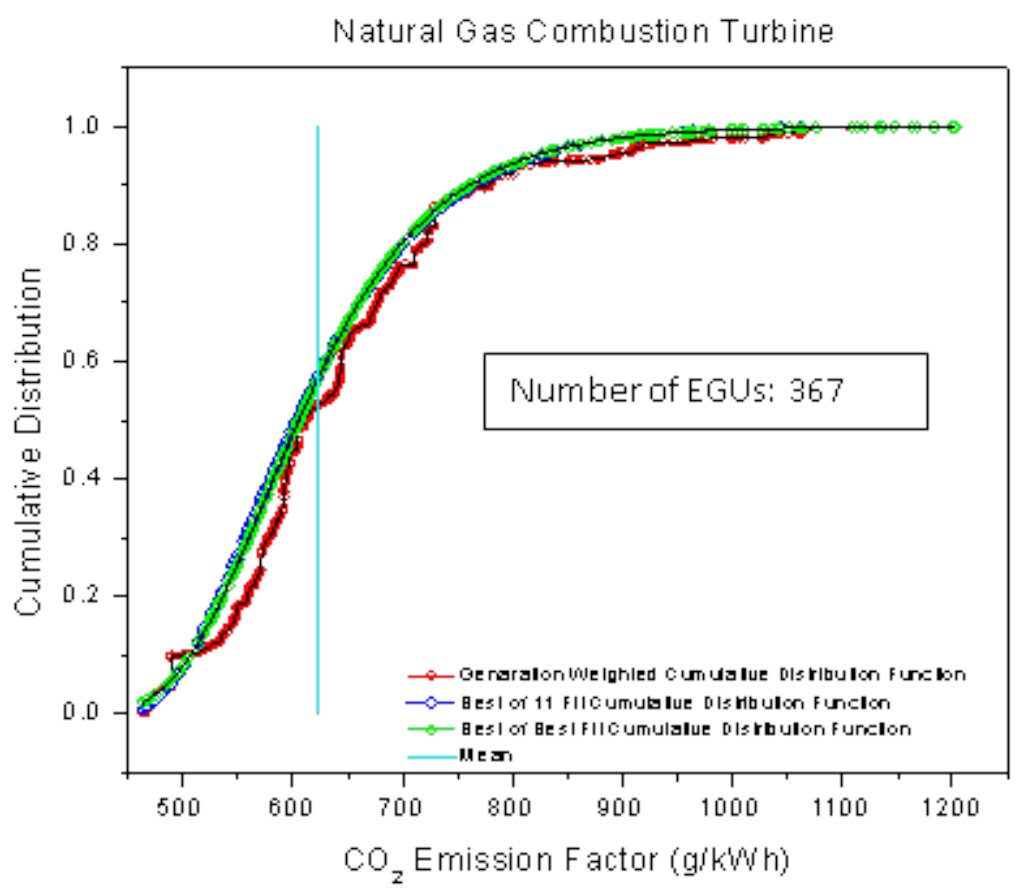


Natural Gas Combustion Turbine

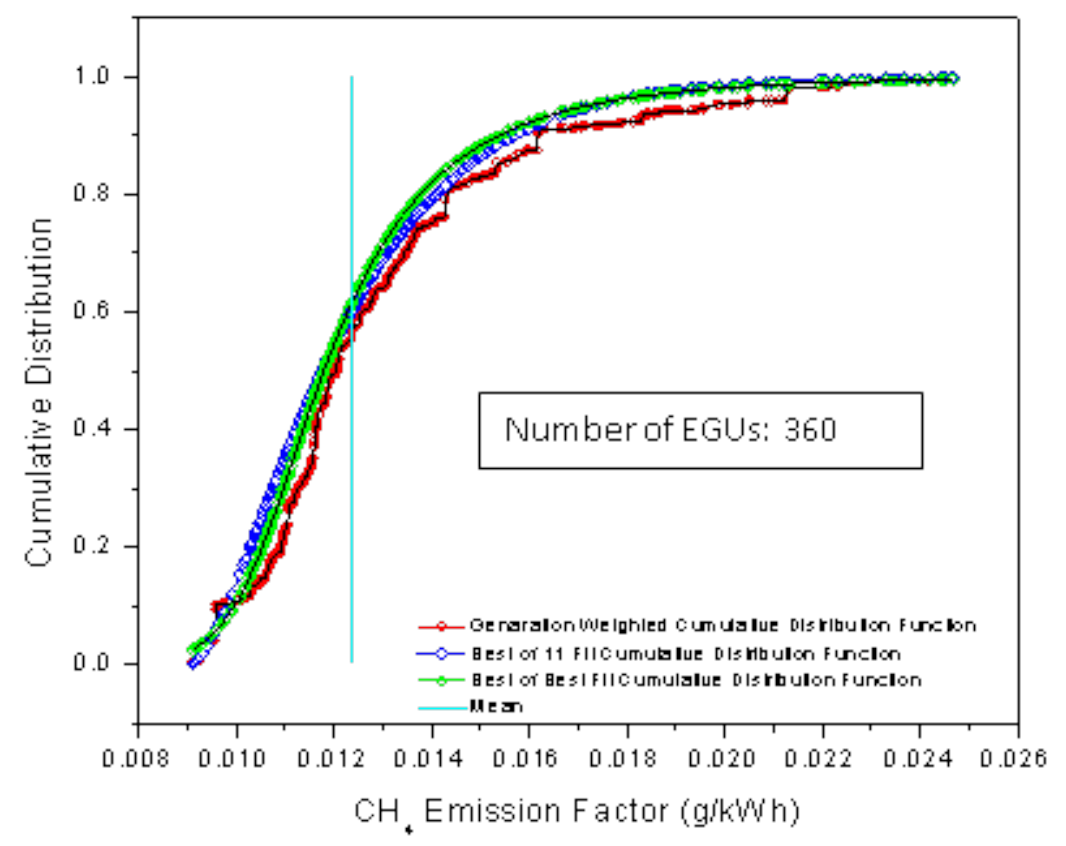

Natural Gas Combustion Turbine

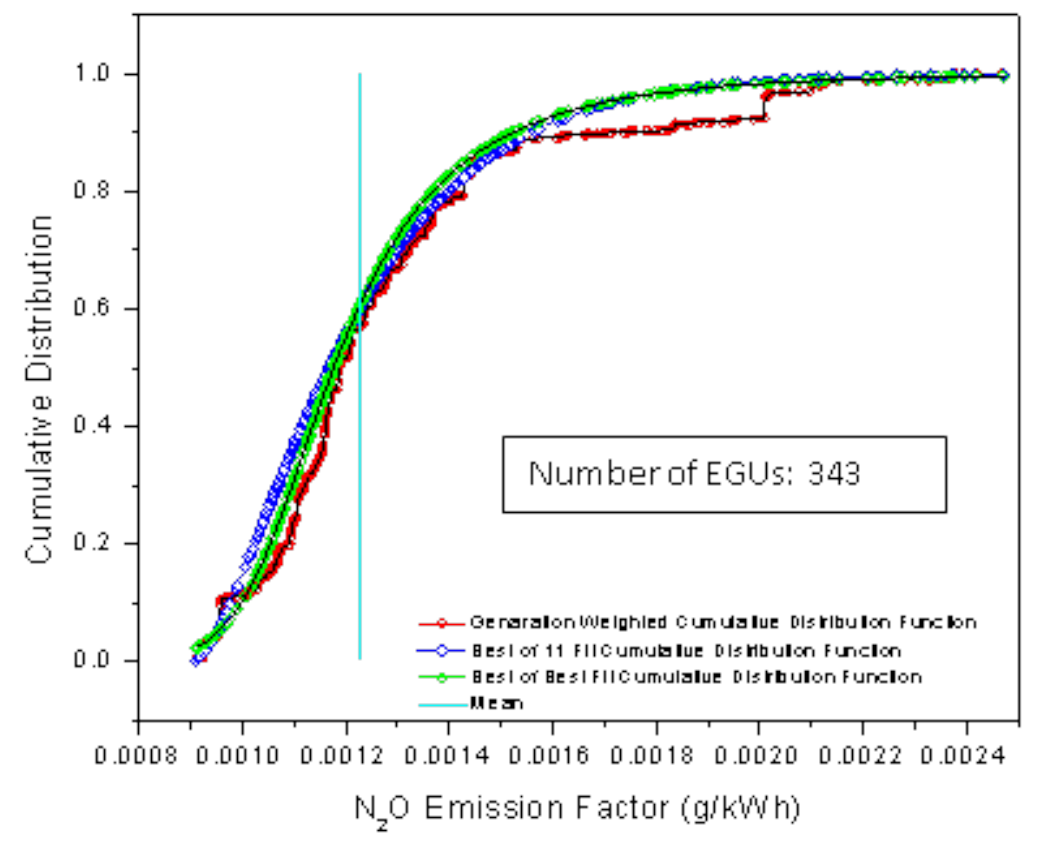



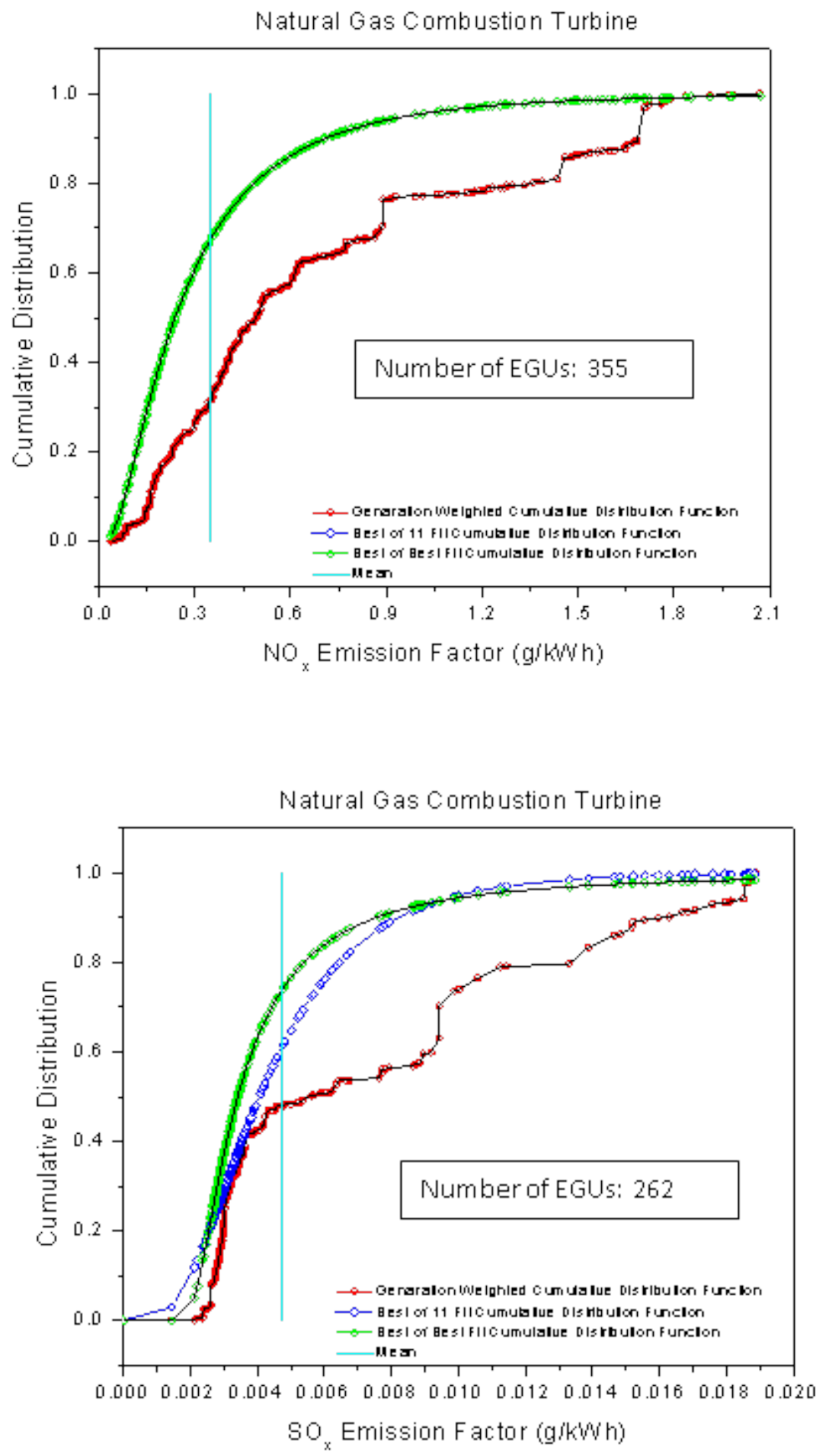

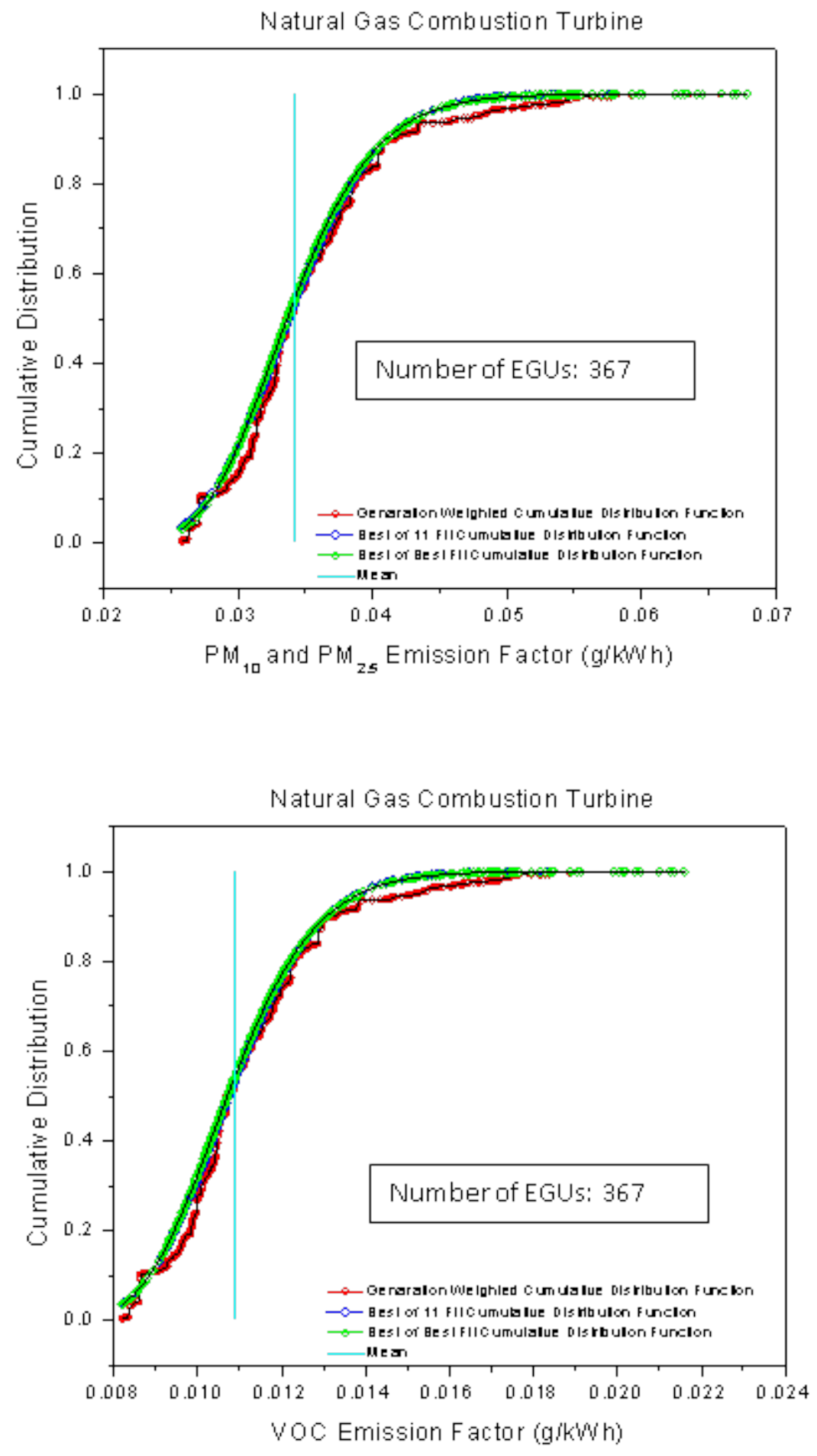


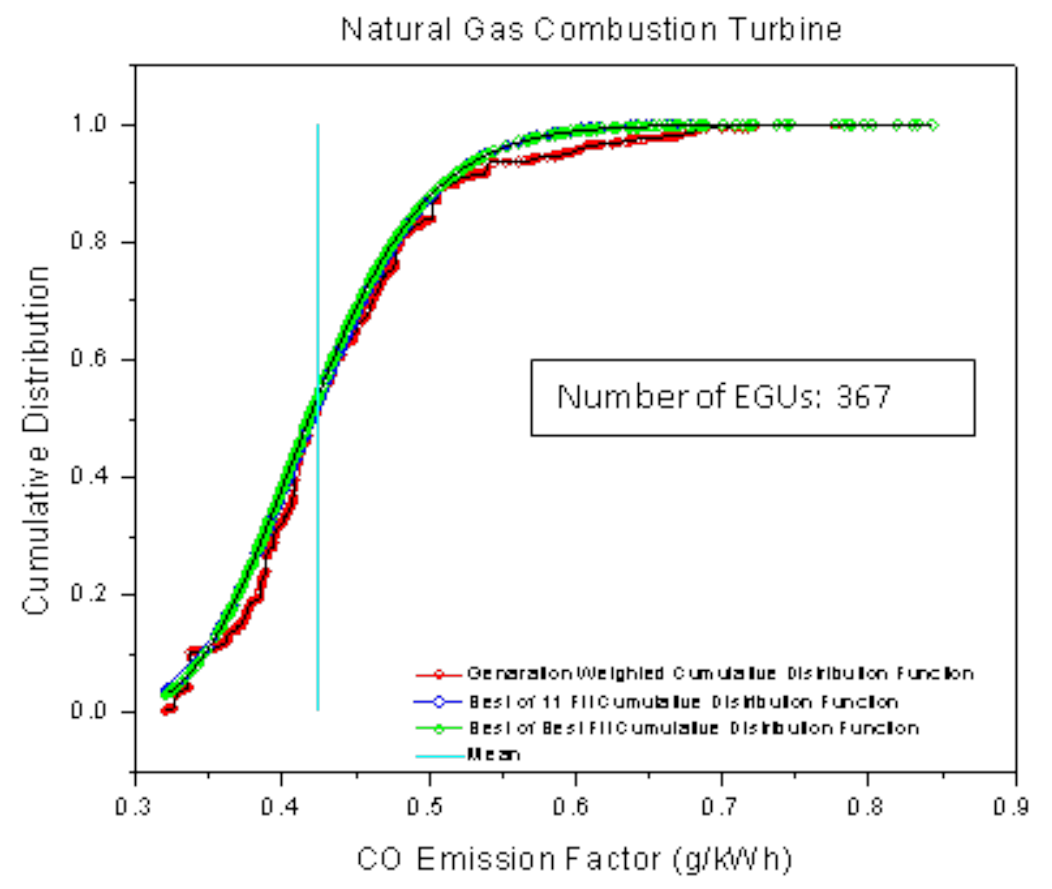

FIGURE A3 Best-fit CDFs of electricity-generationweighted GHG and CAP emission factors for natural gas-fired combustion turbines.

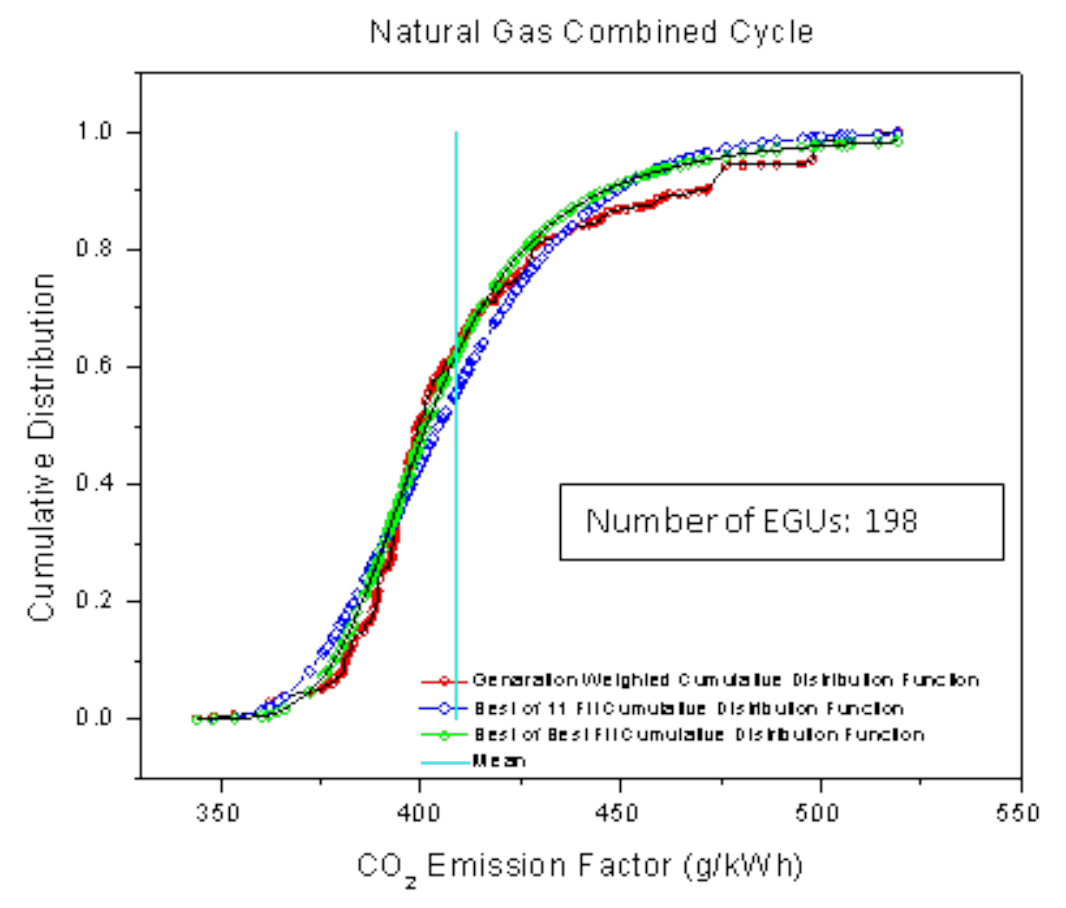



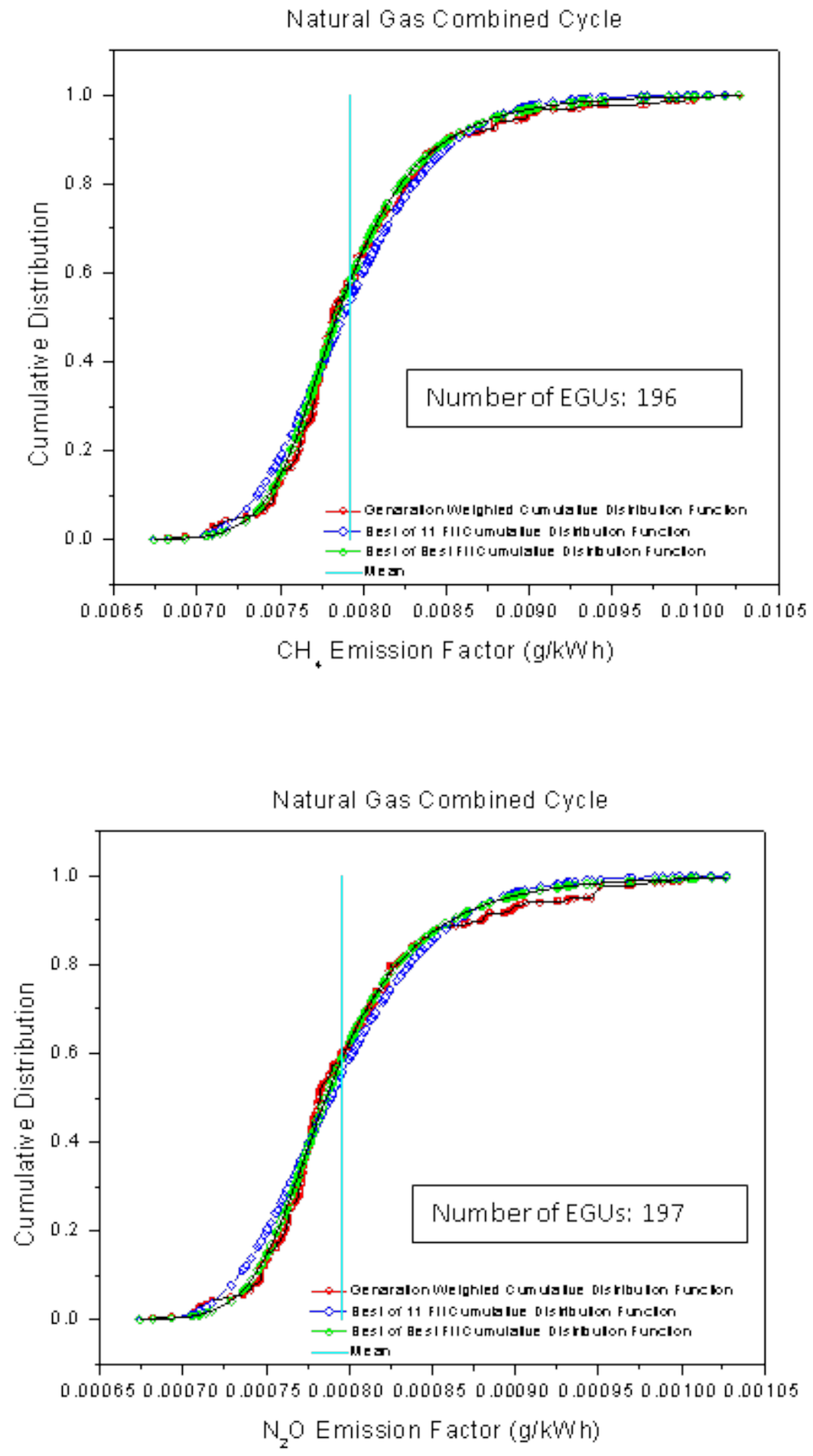

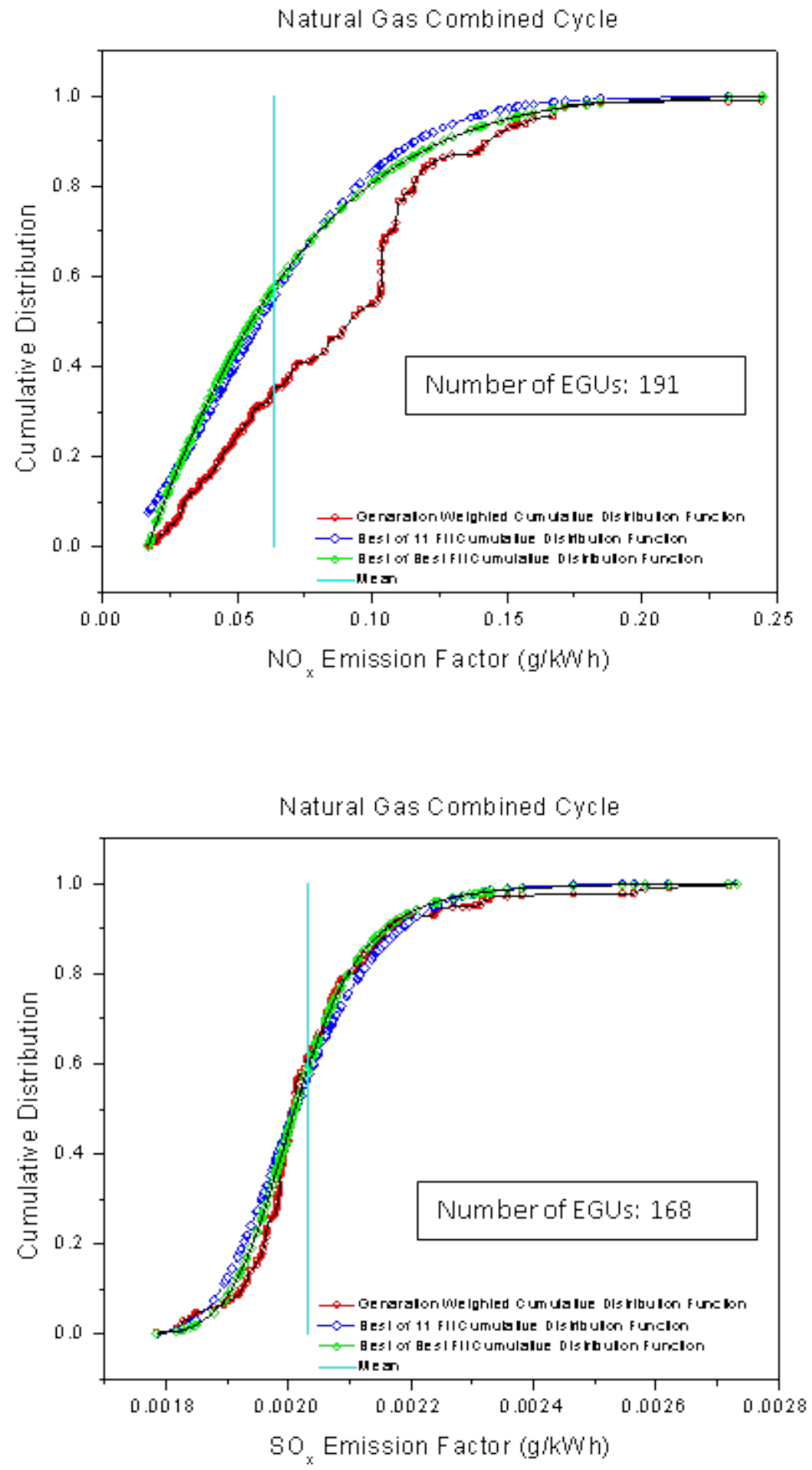

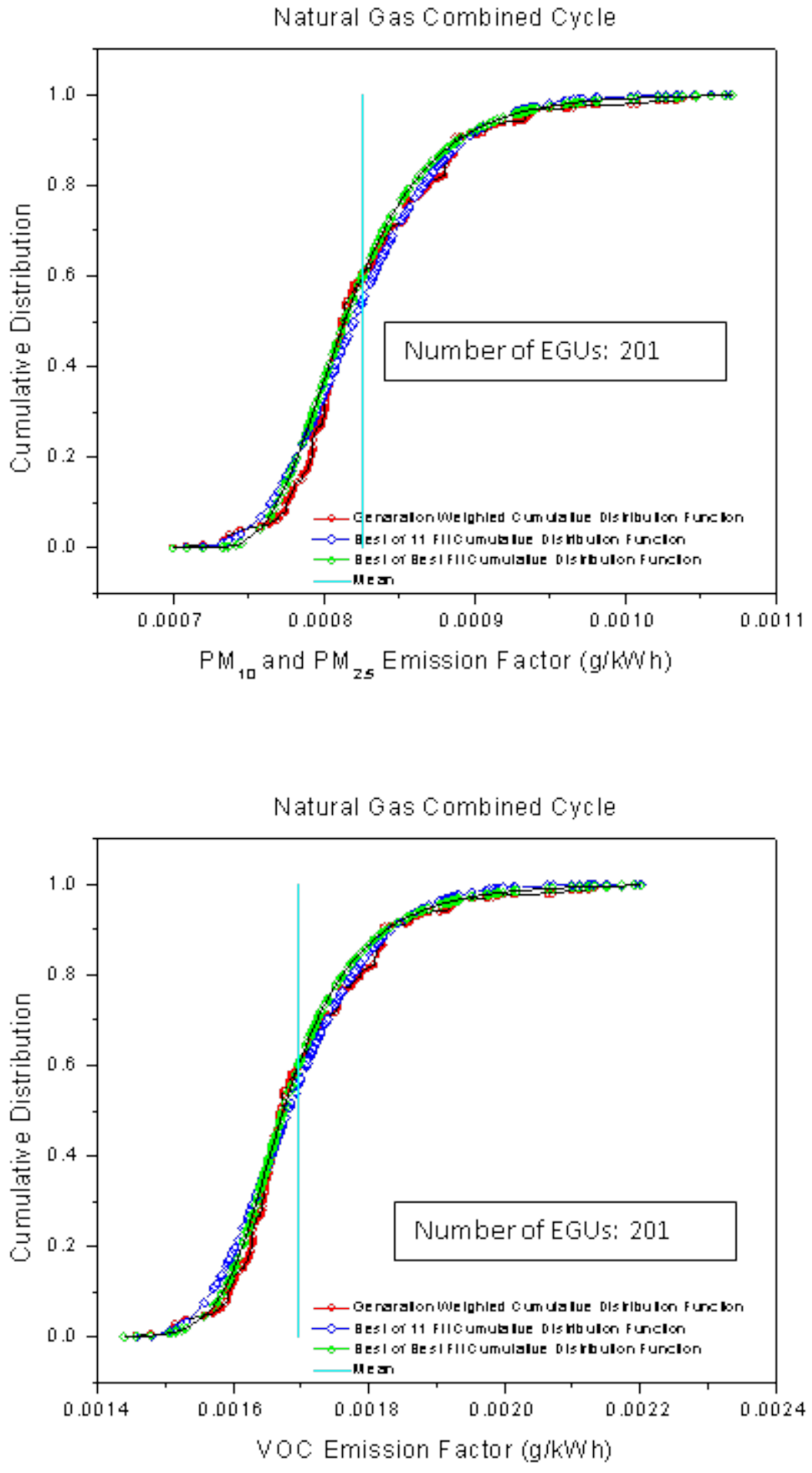


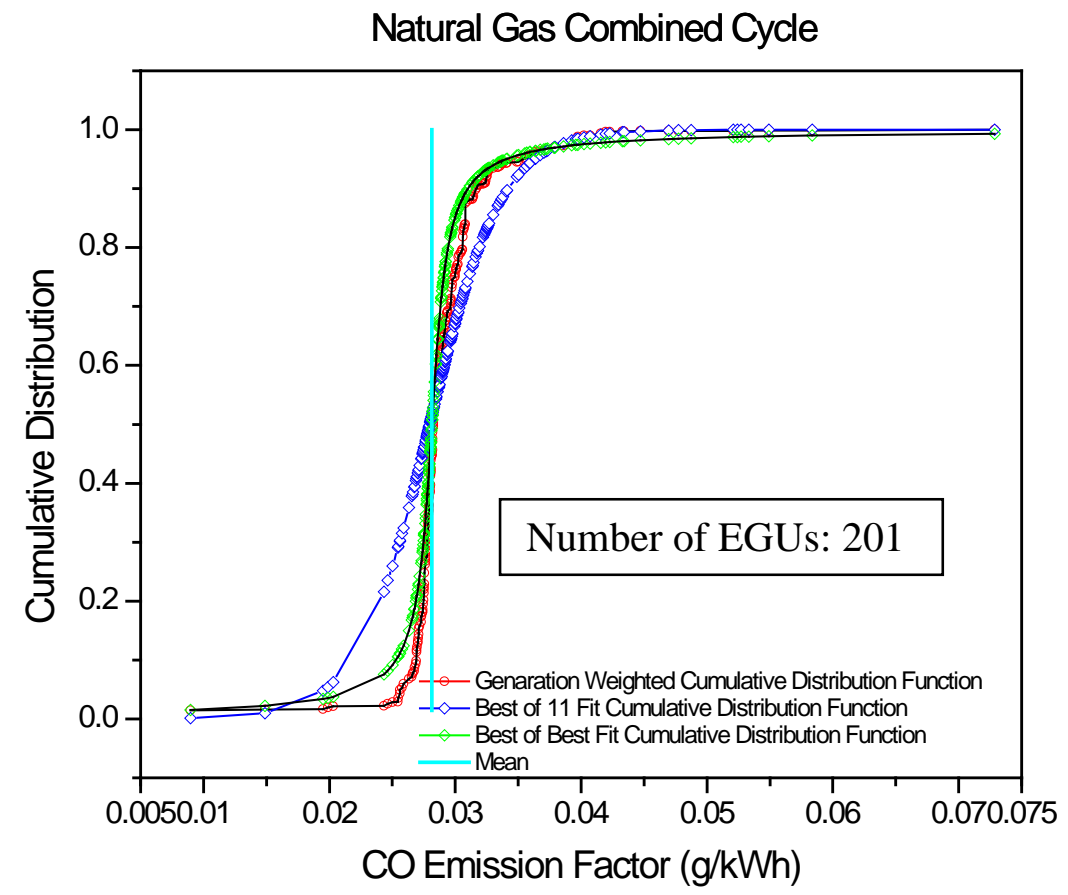

\section{FIGURE A4 Best-fit CDFs of electricity-generation-weighted GHG and CAP emission factors for natural gas-fired combined- cycle plants.}

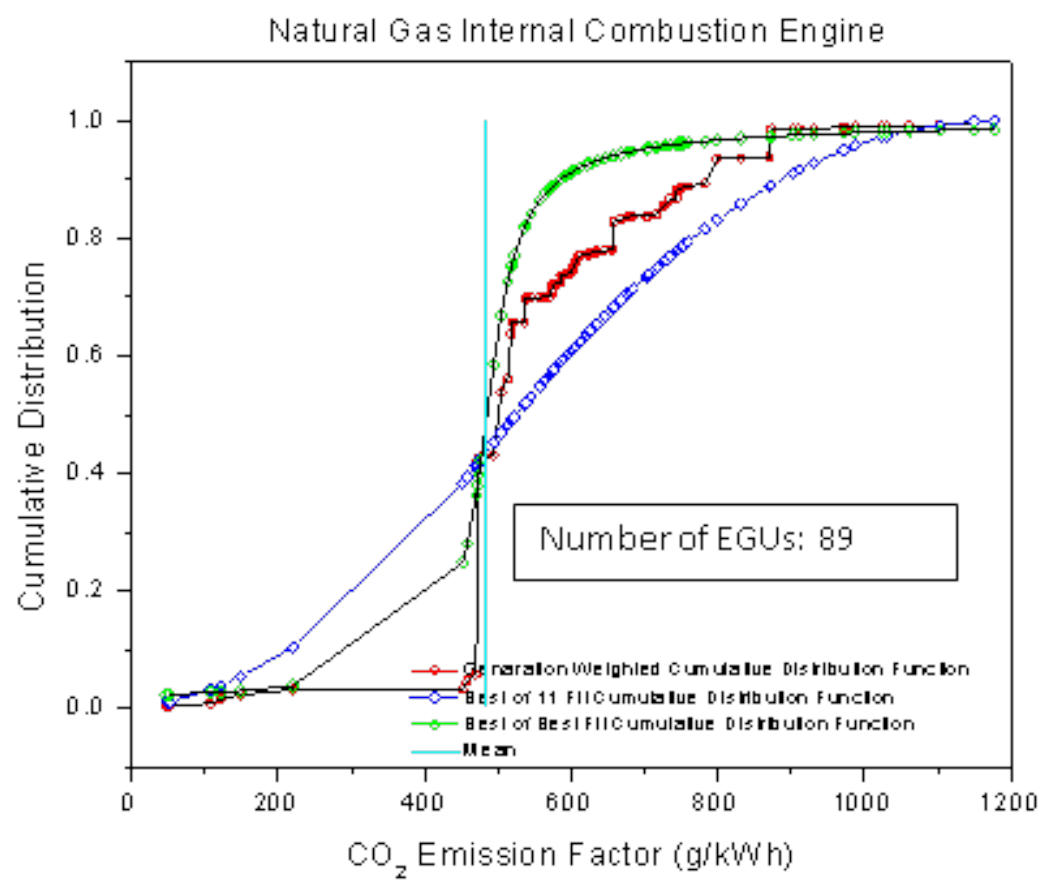



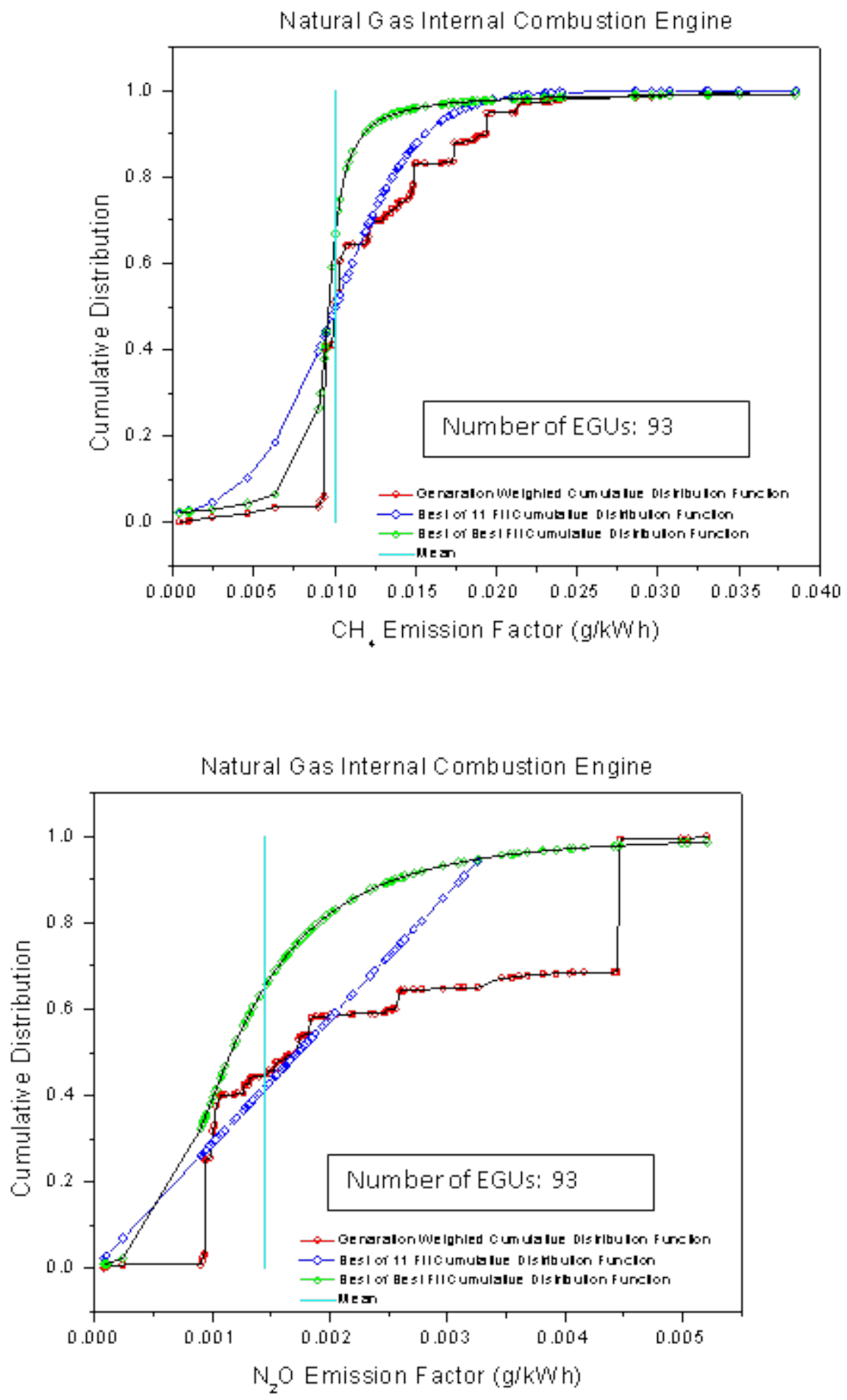

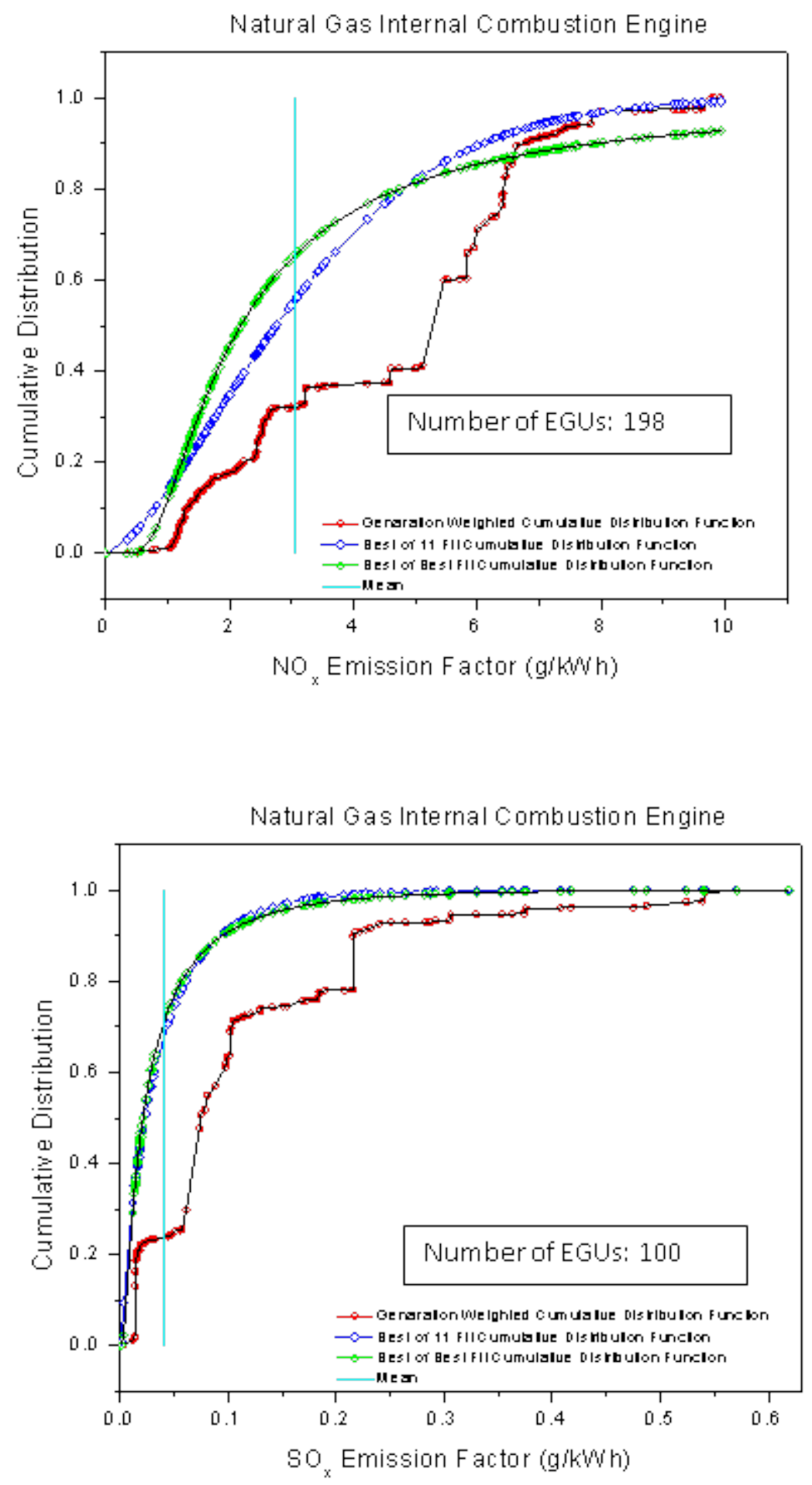

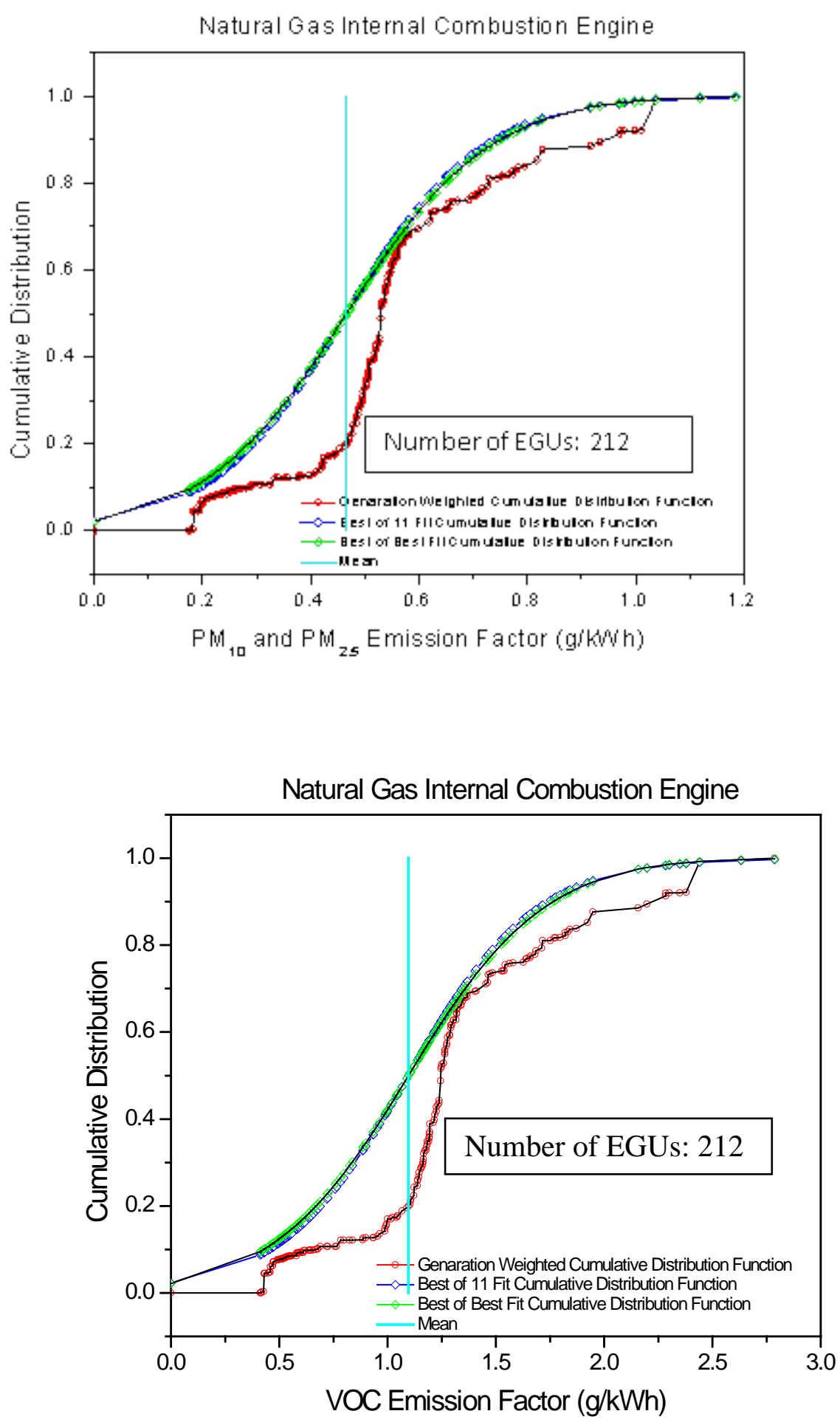


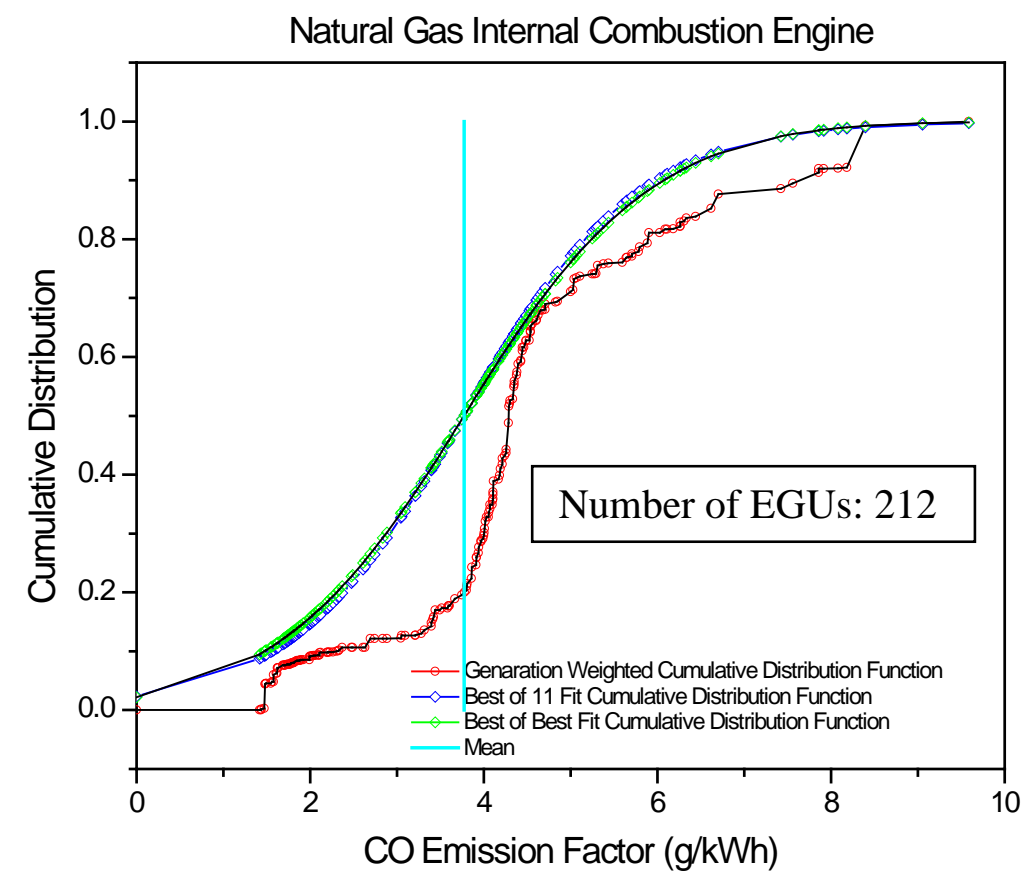

FIGURE A5 Best-fit CDFs of electricity-generation-weighted GHG and CAP emission factors for natural gas-fired internal combustion engines.

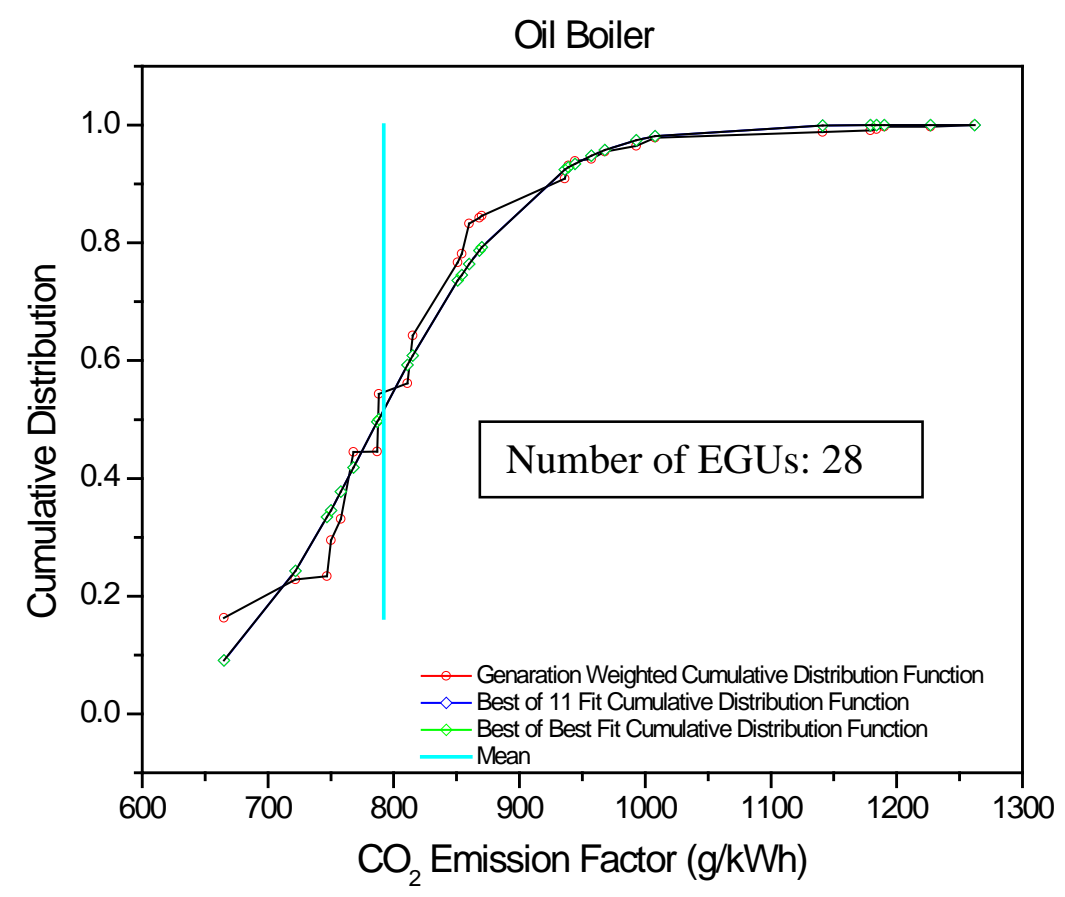



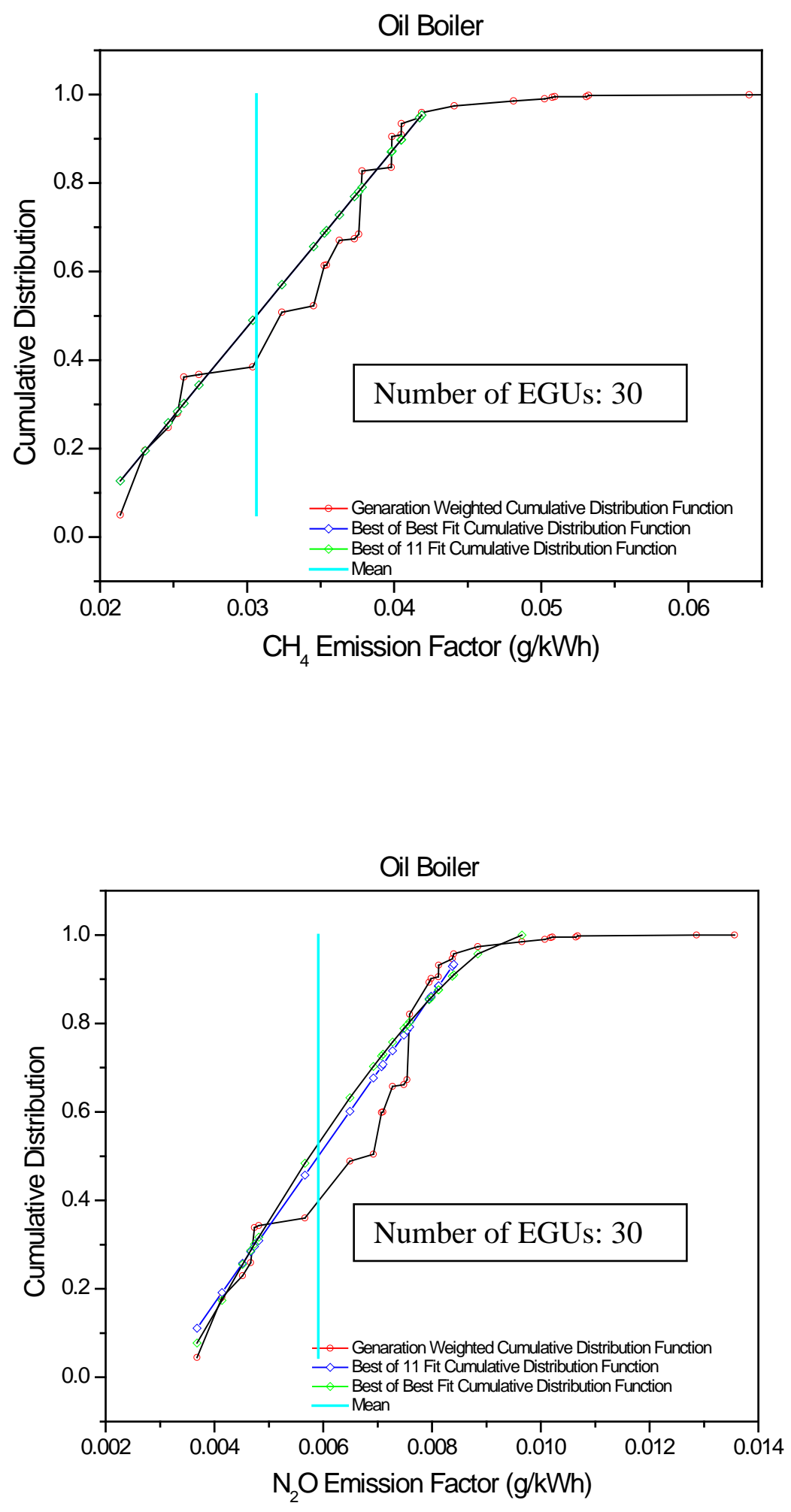

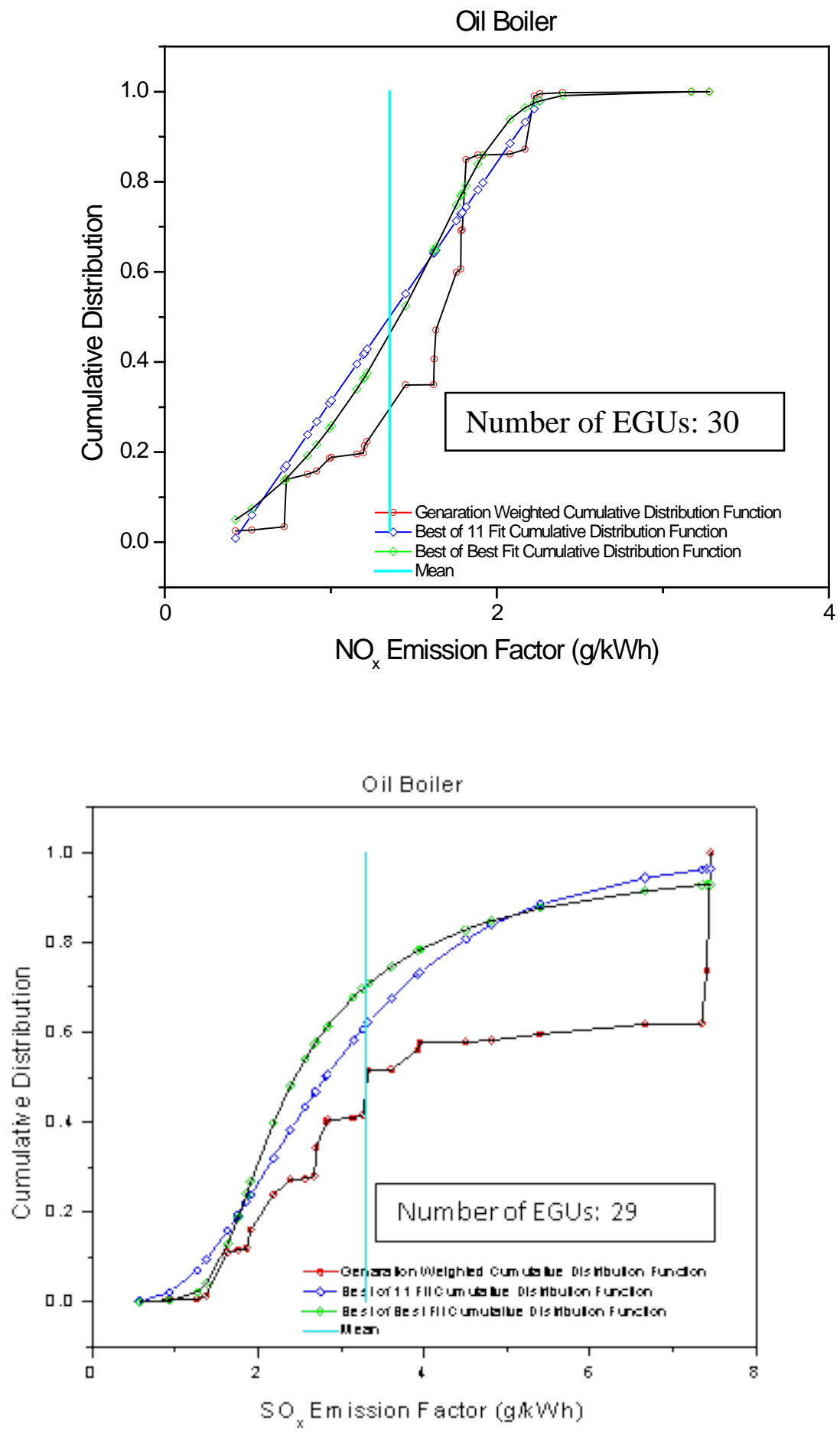

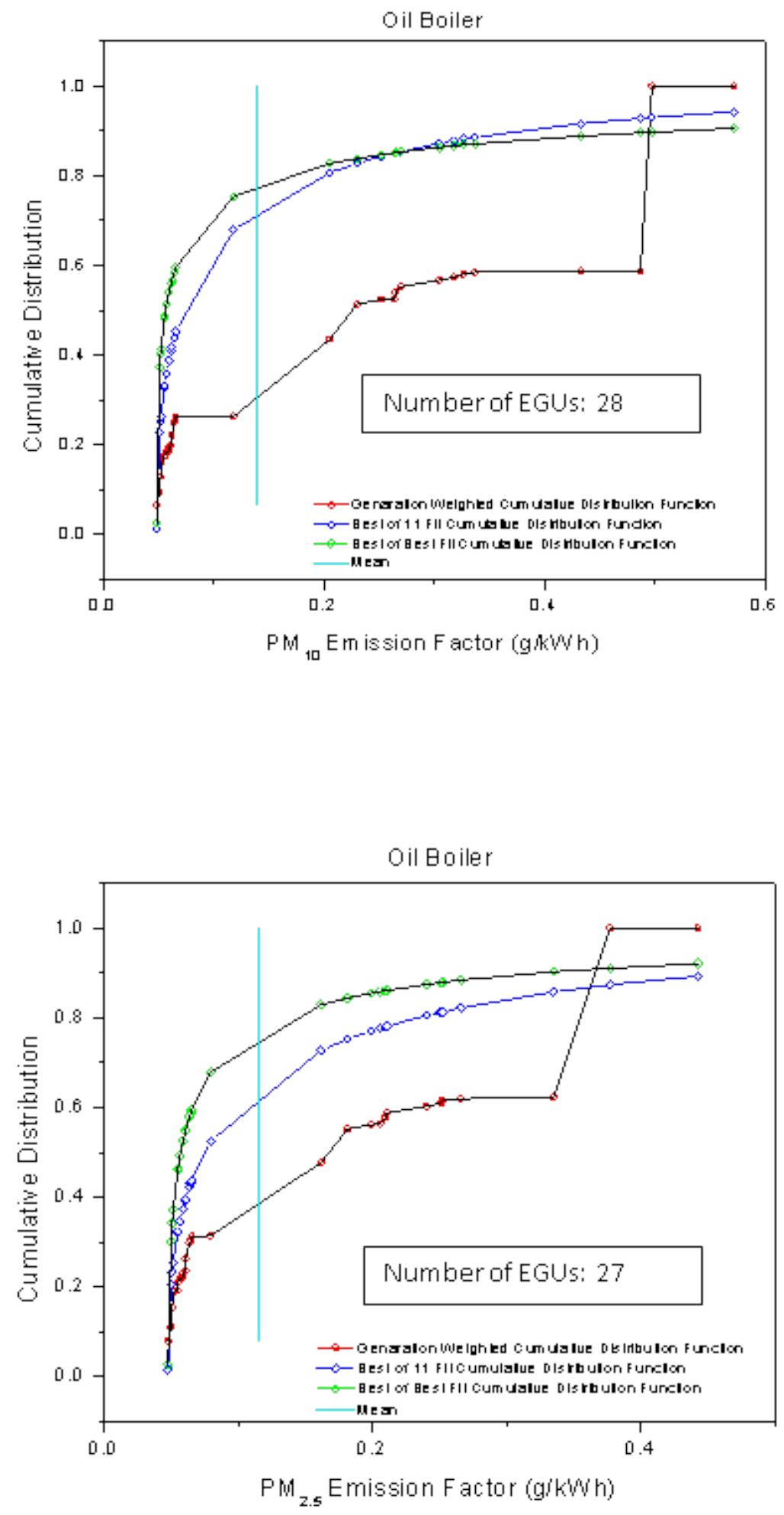

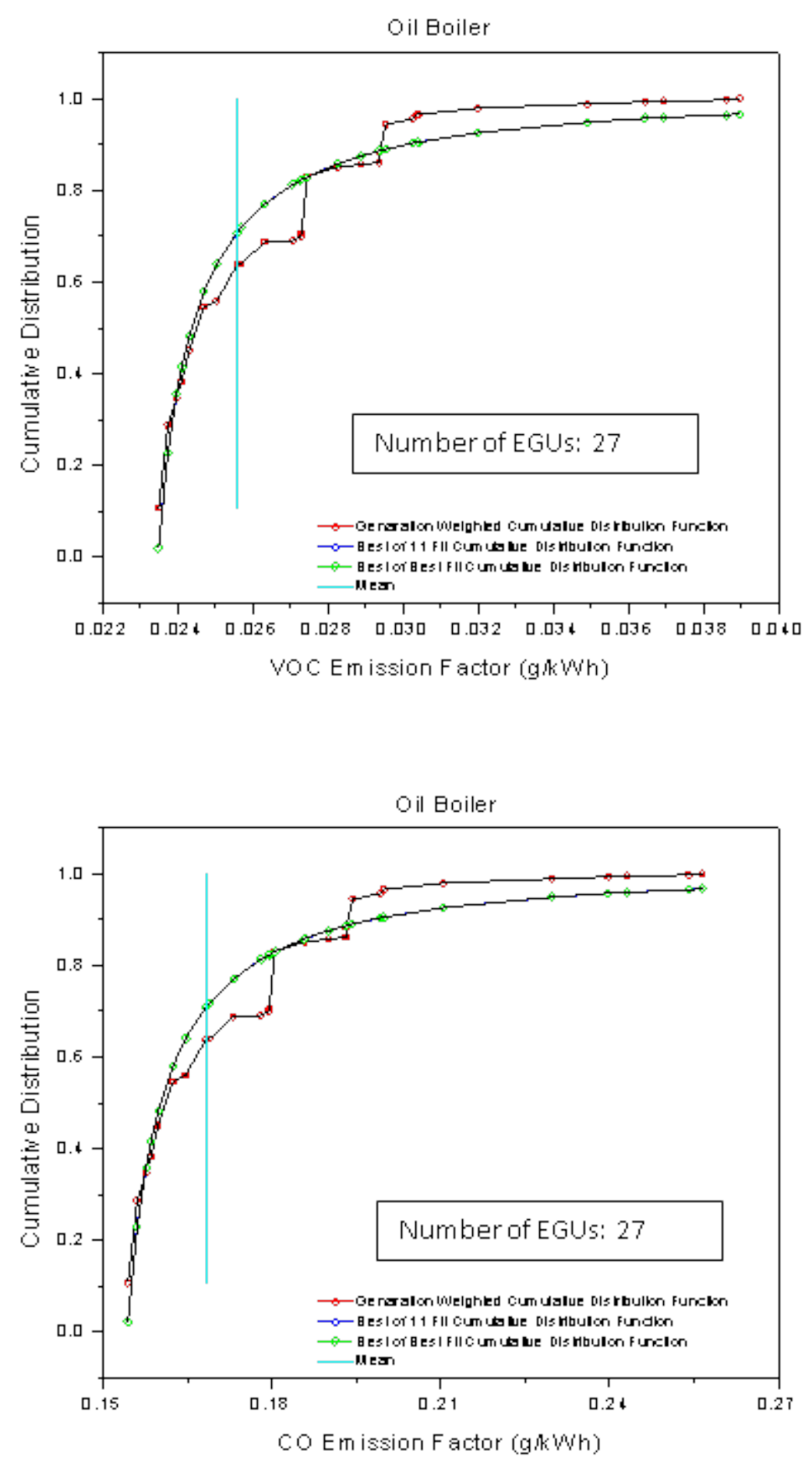

FIGURE A6 Best-fit CDFs of electricity-generationweighted GHG and CAP emission factors for oil-fired boilers. 

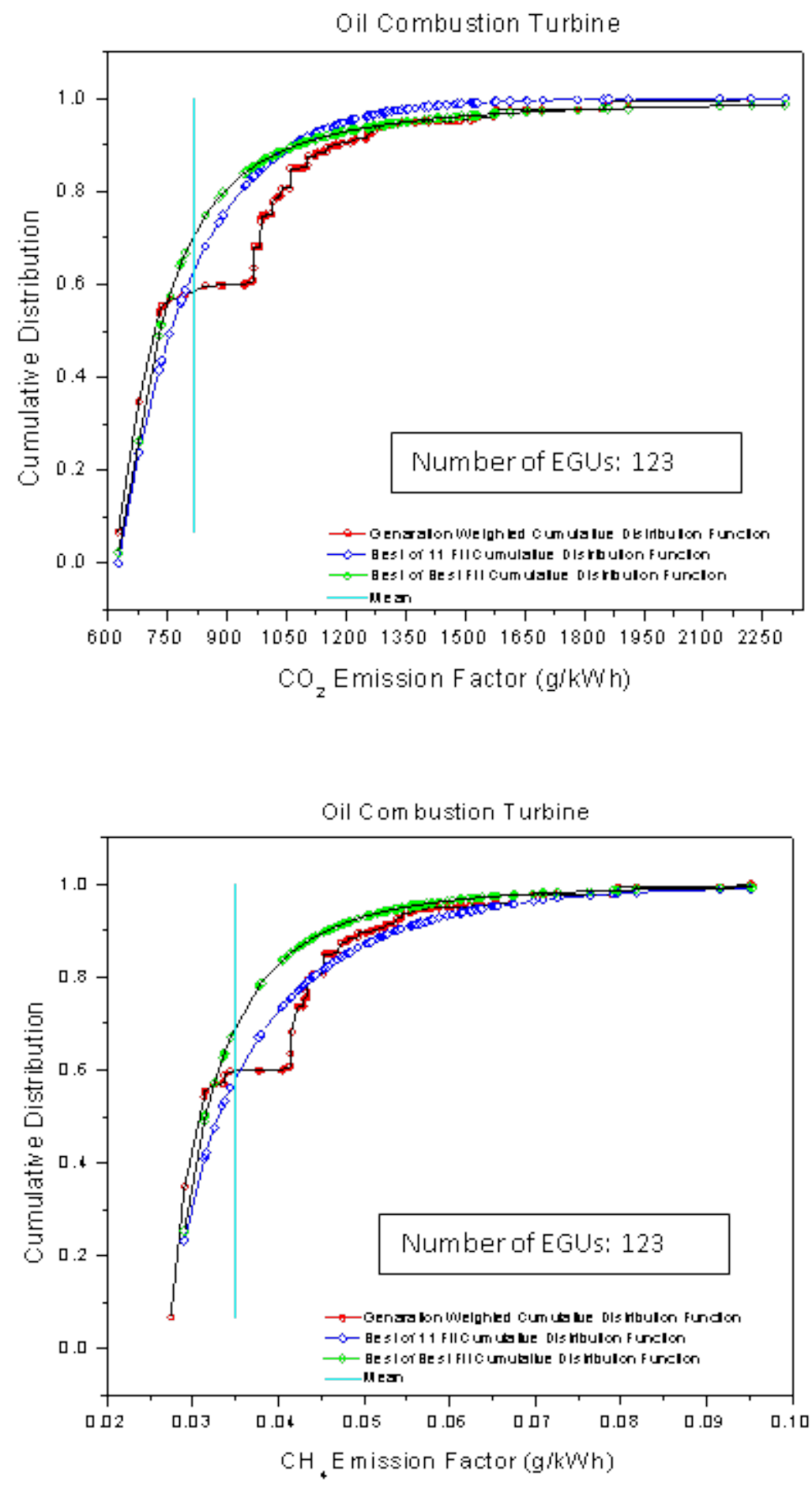

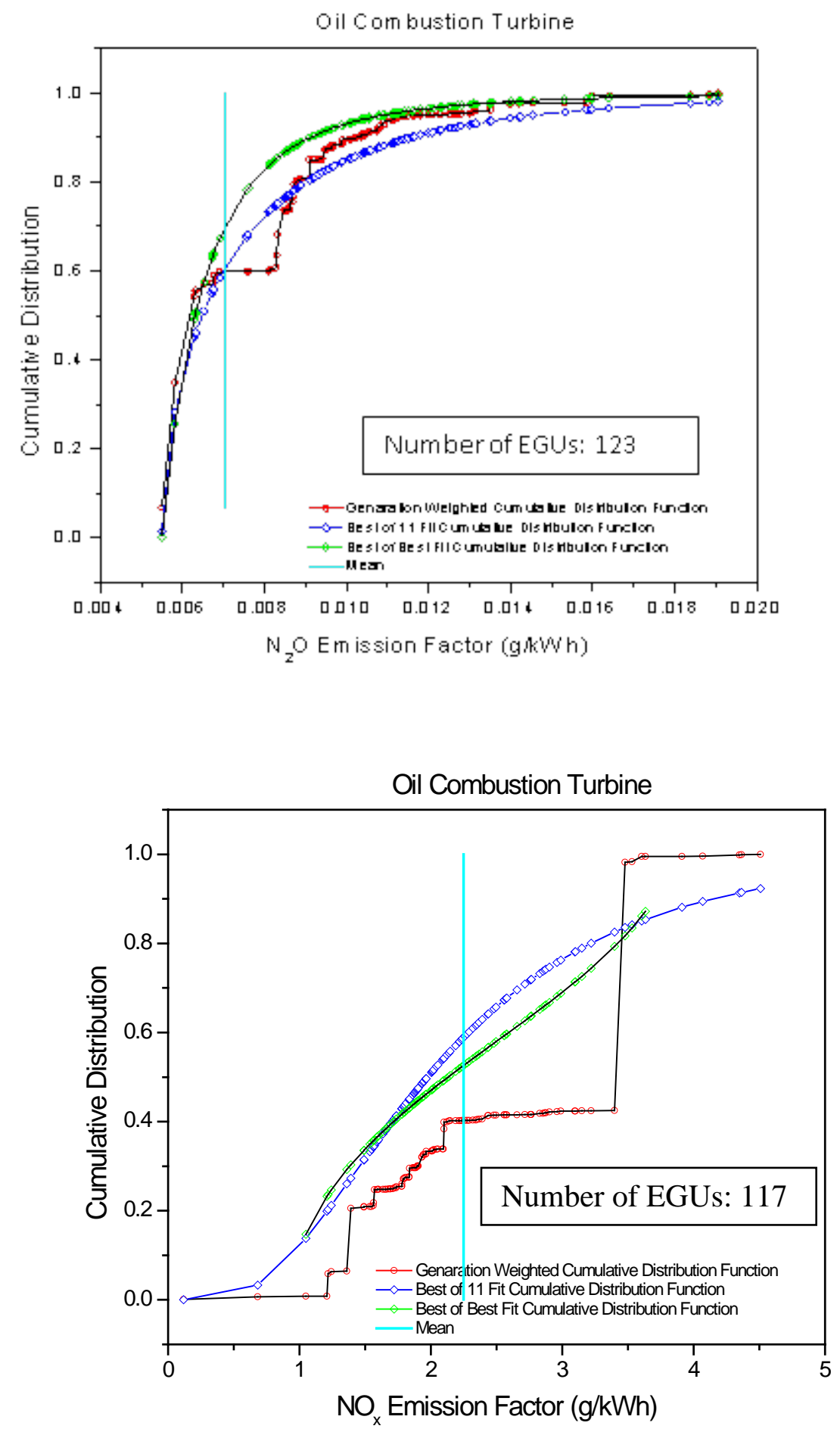

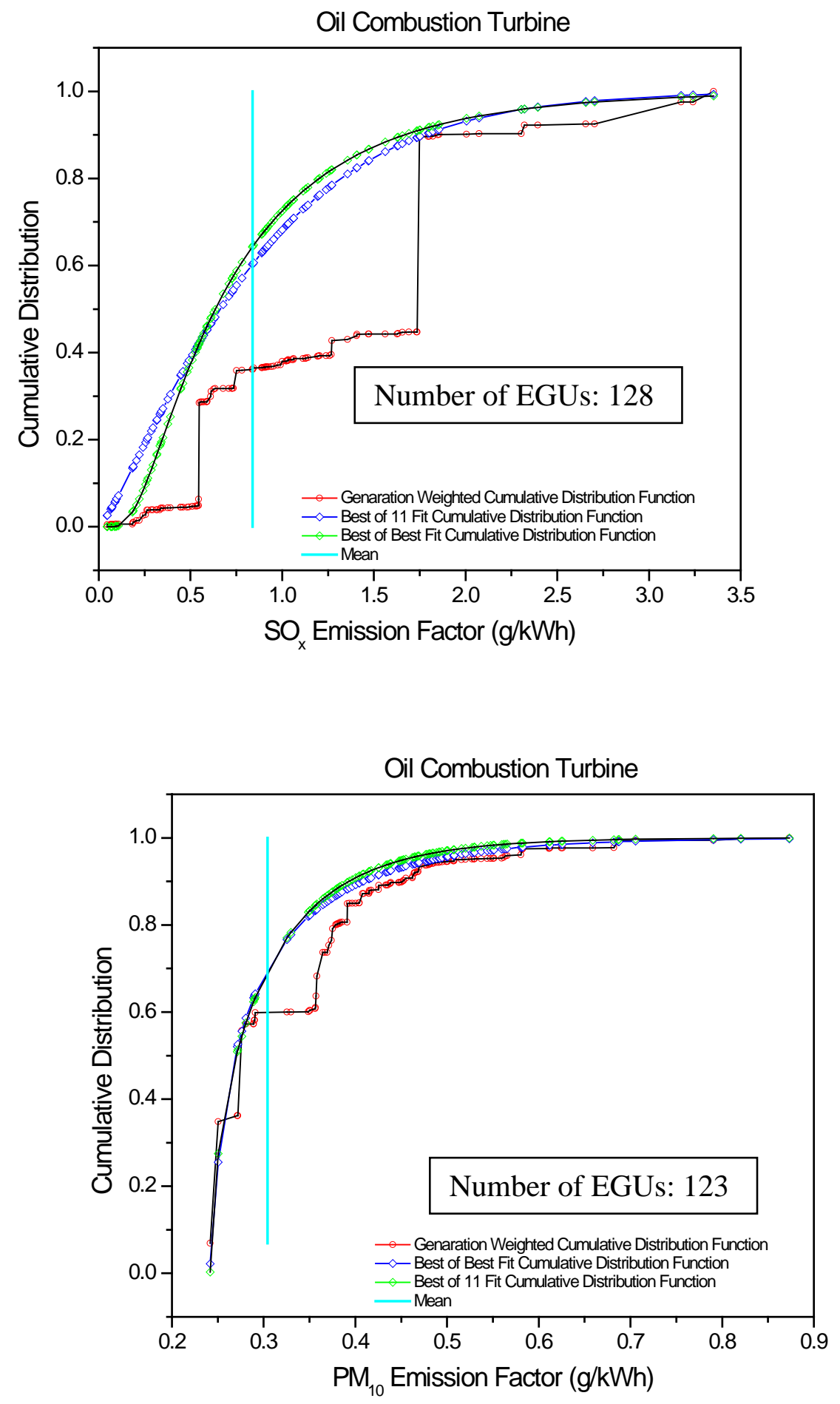

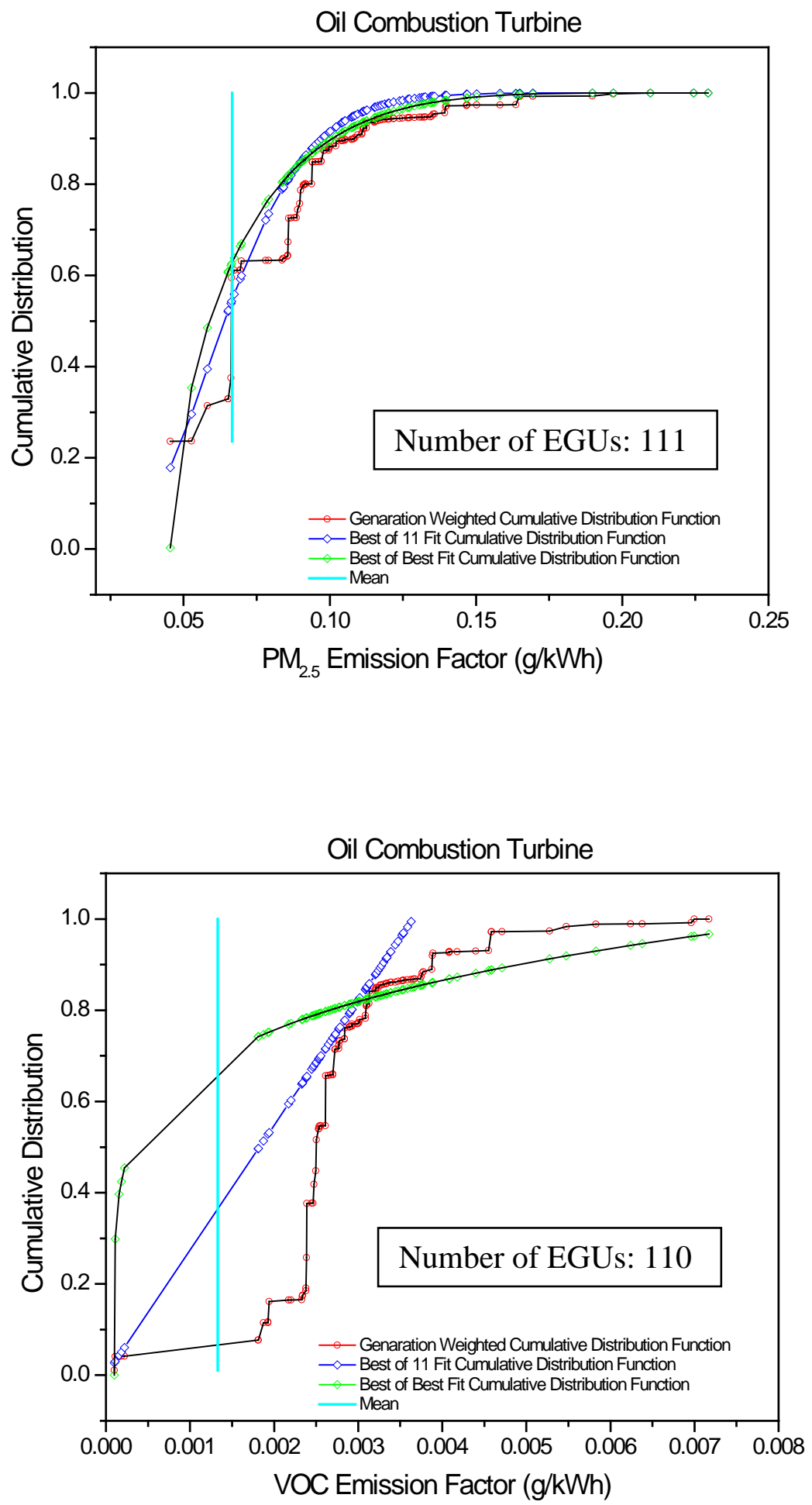


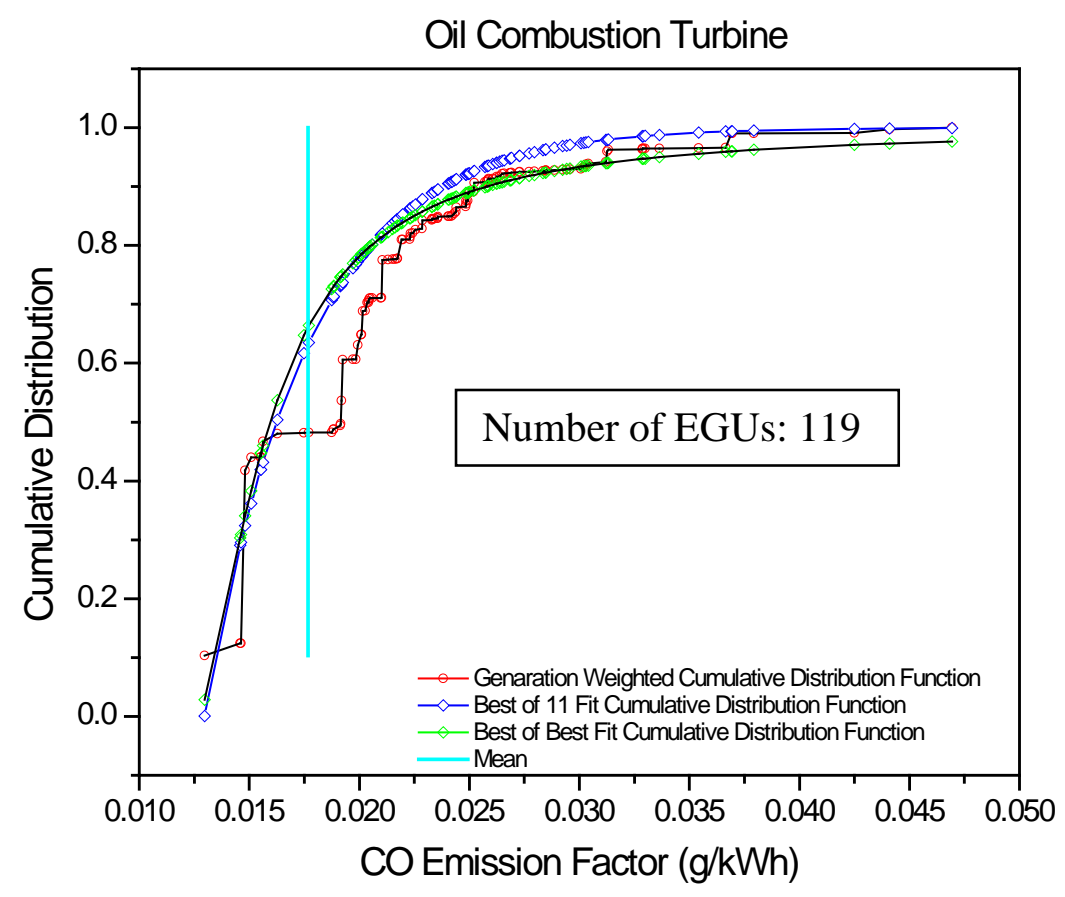

FIGURE A7 Best-fit CDFs of electricity-generation-weighted GHG and CAP emission factors for oil-fired combustion turbines.

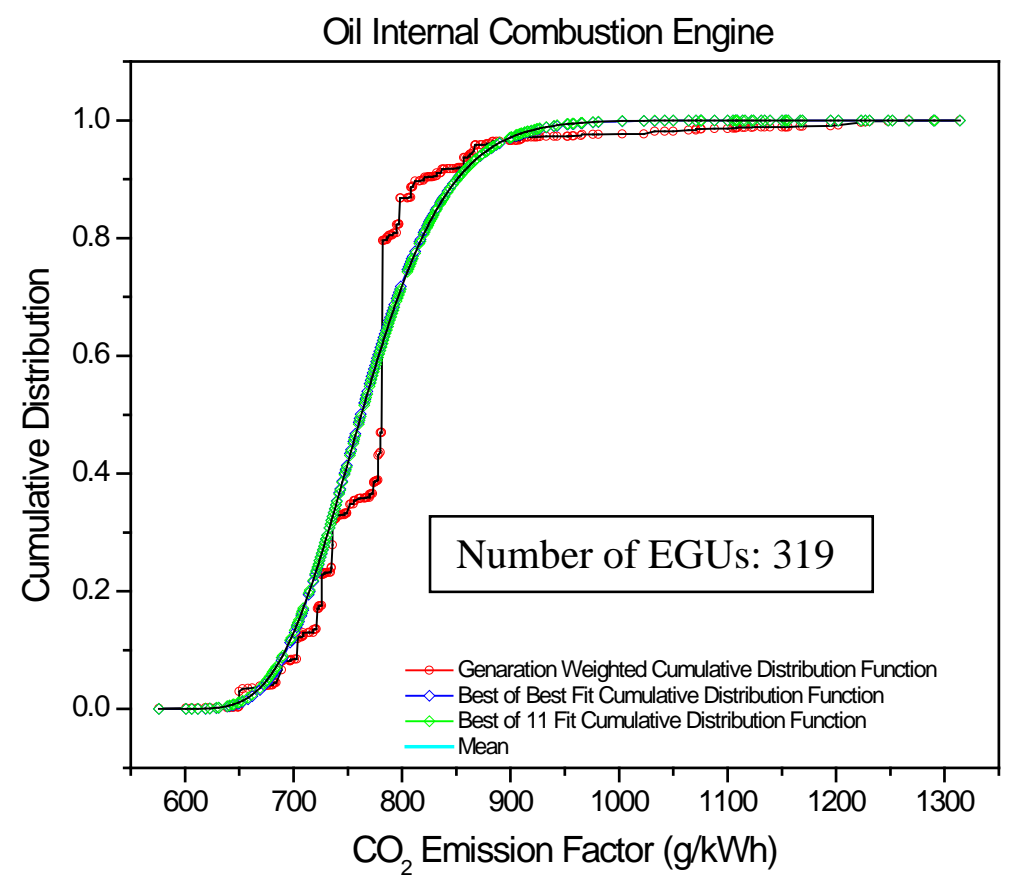



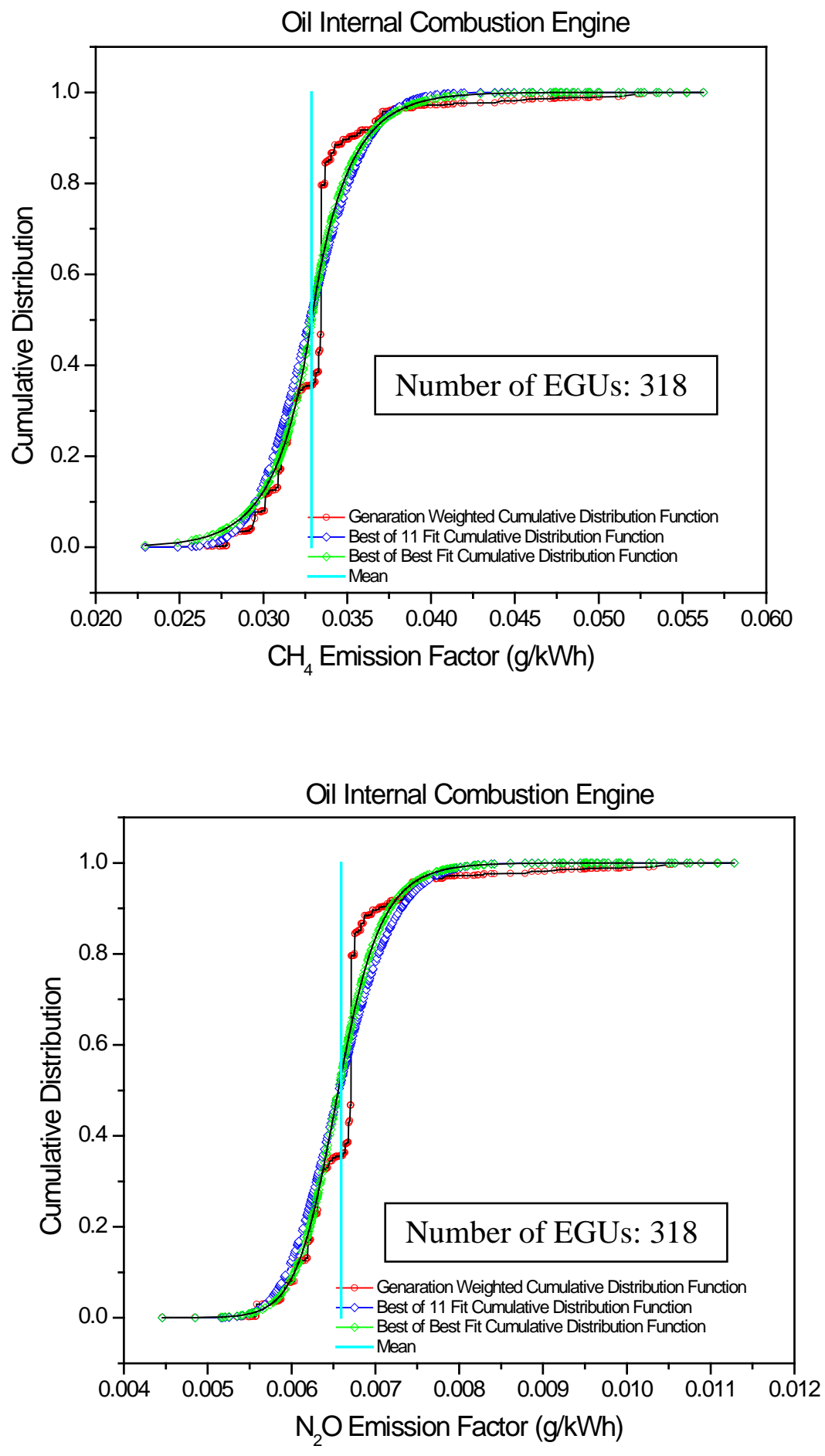

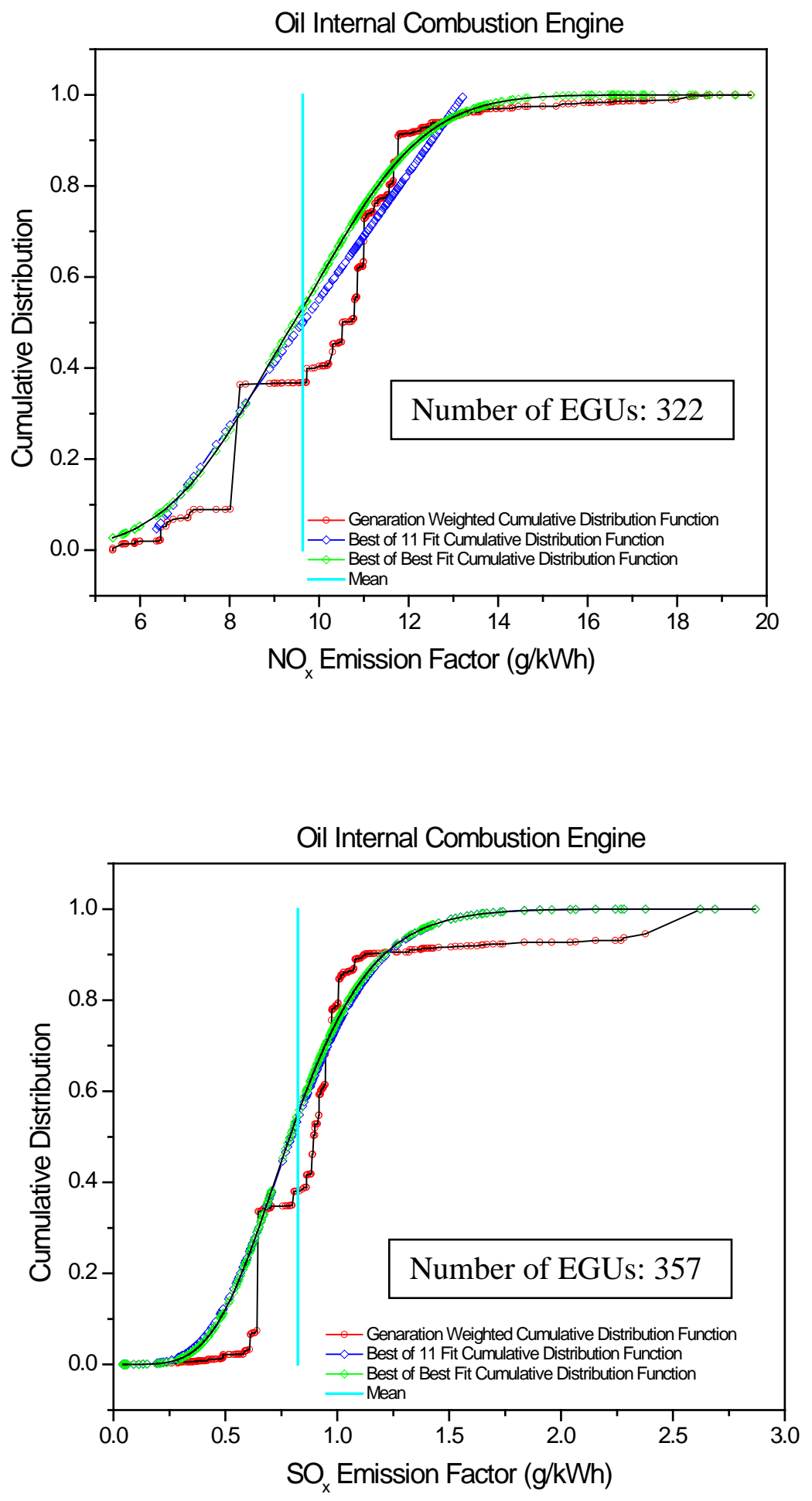

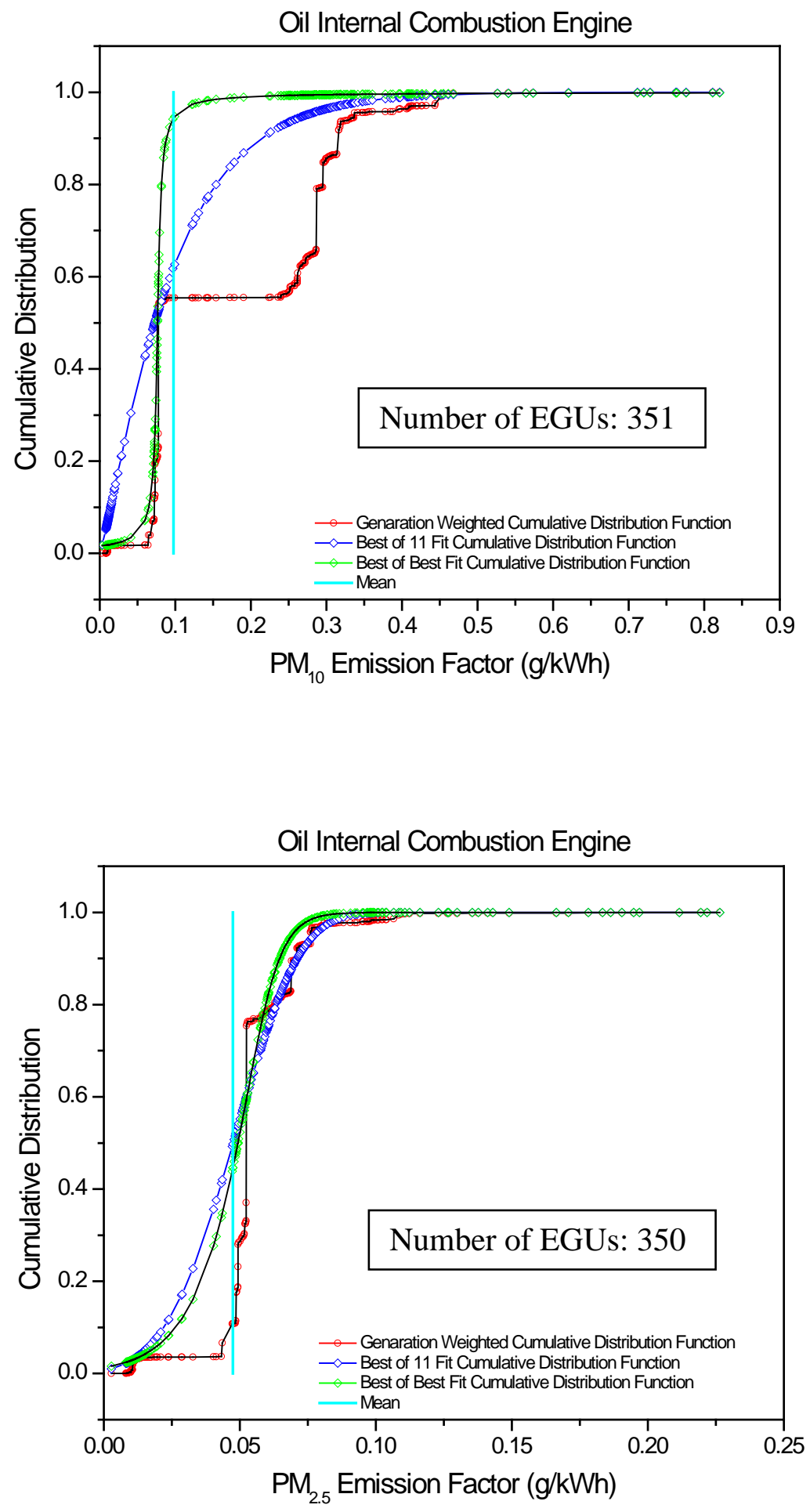

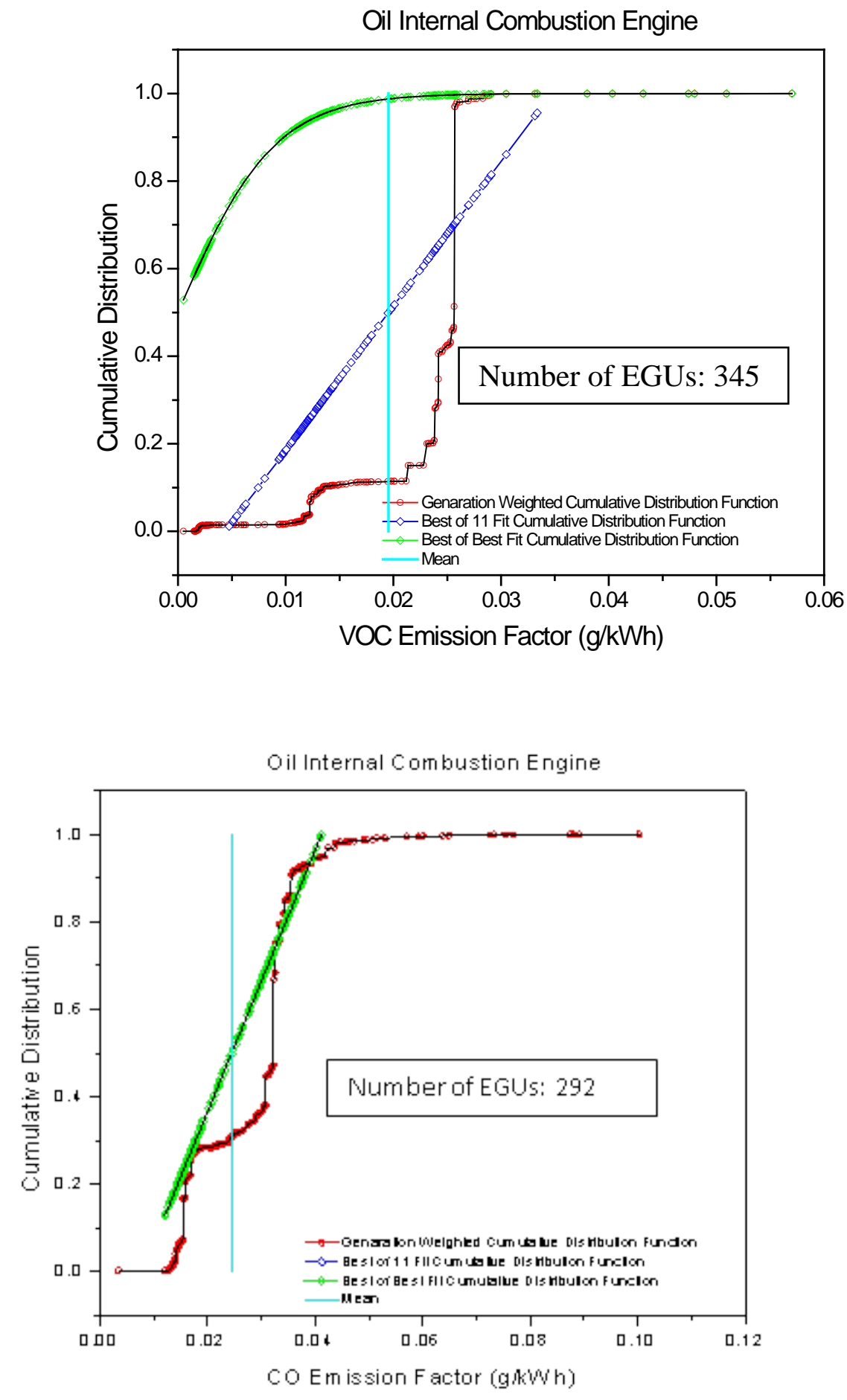

FIGURE A8 Best-fit CDFs of electricity-generationweighted GHG and CAP emission factors for oil-fired internal combustion engines. 

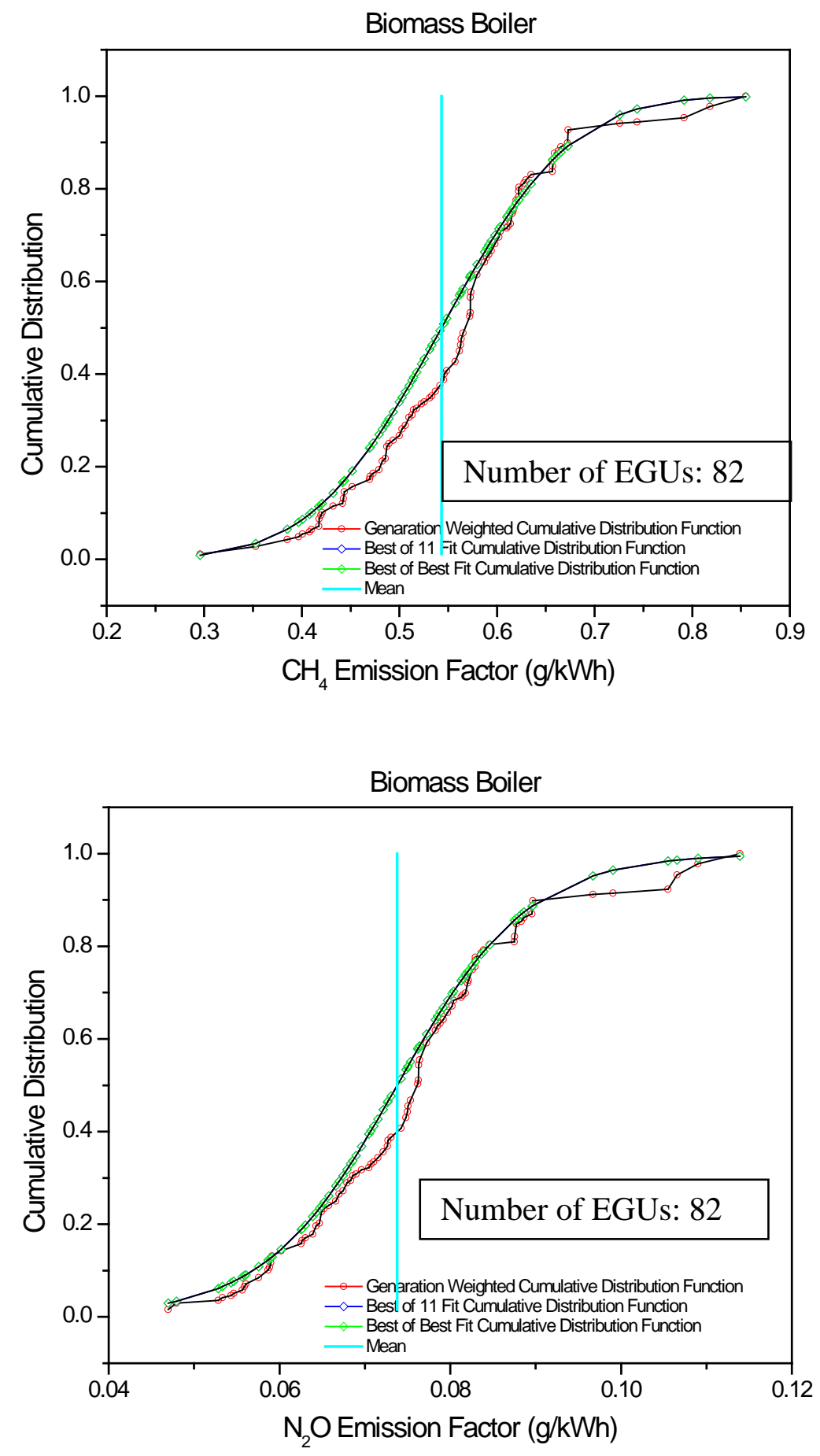

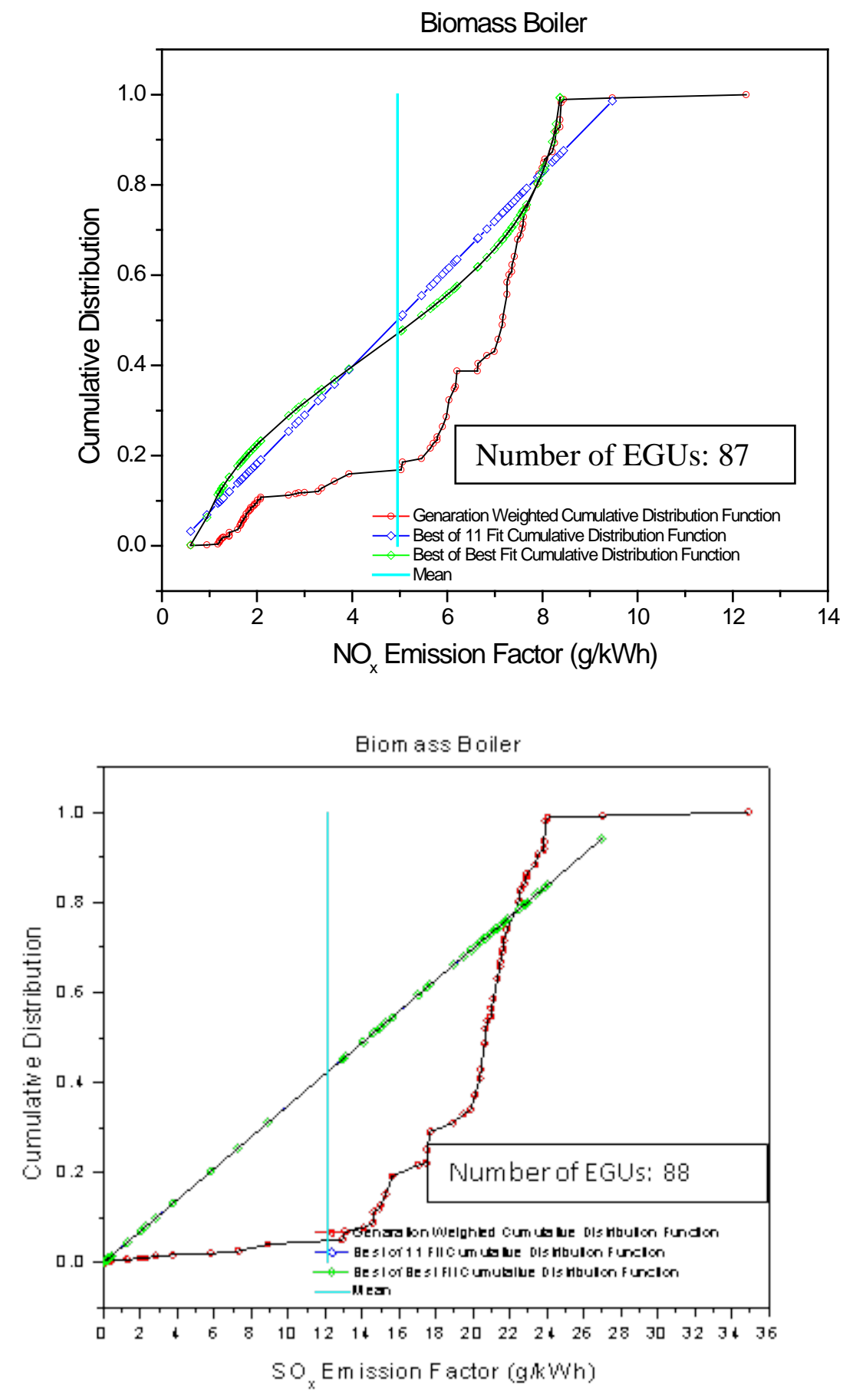

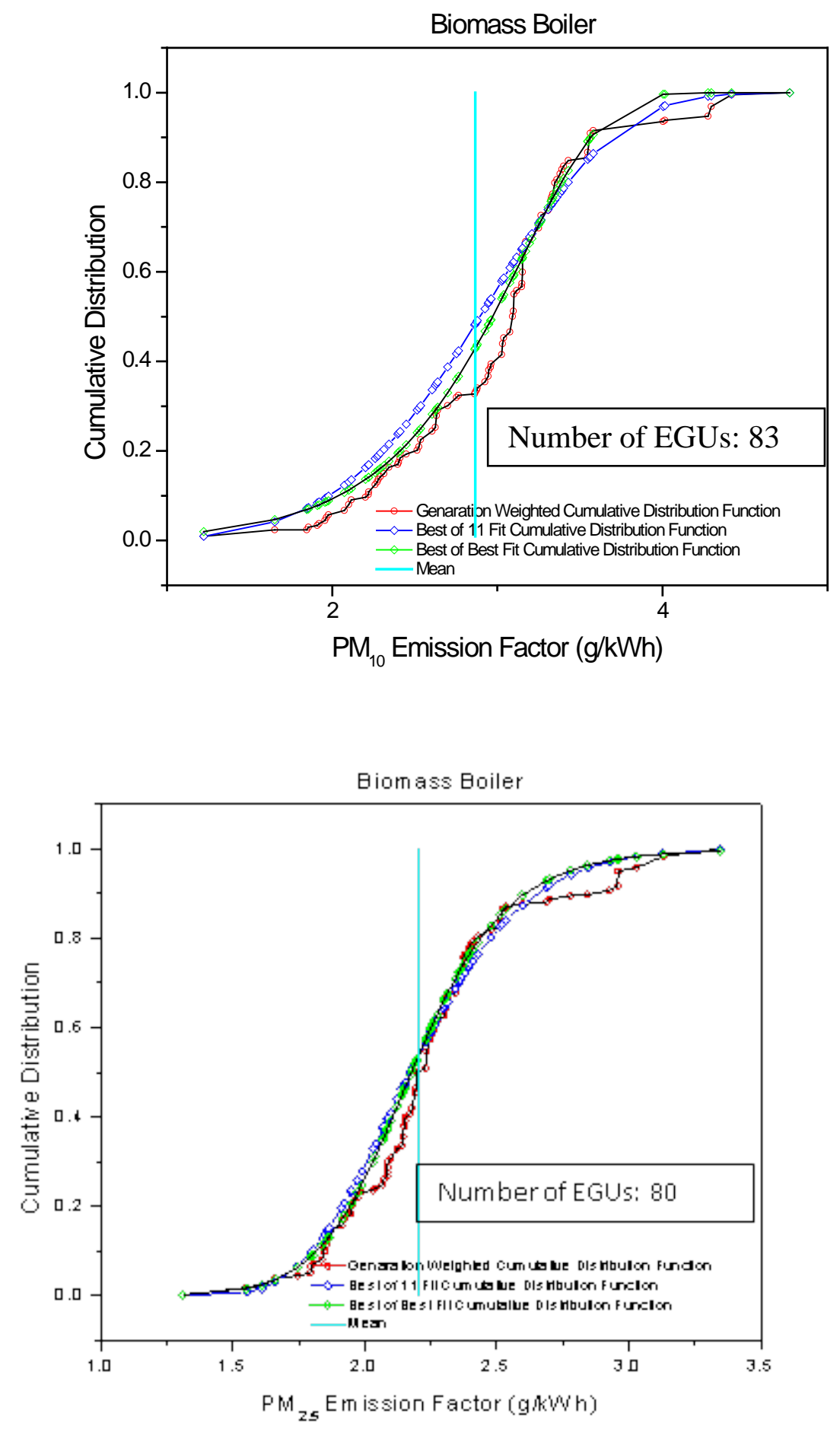

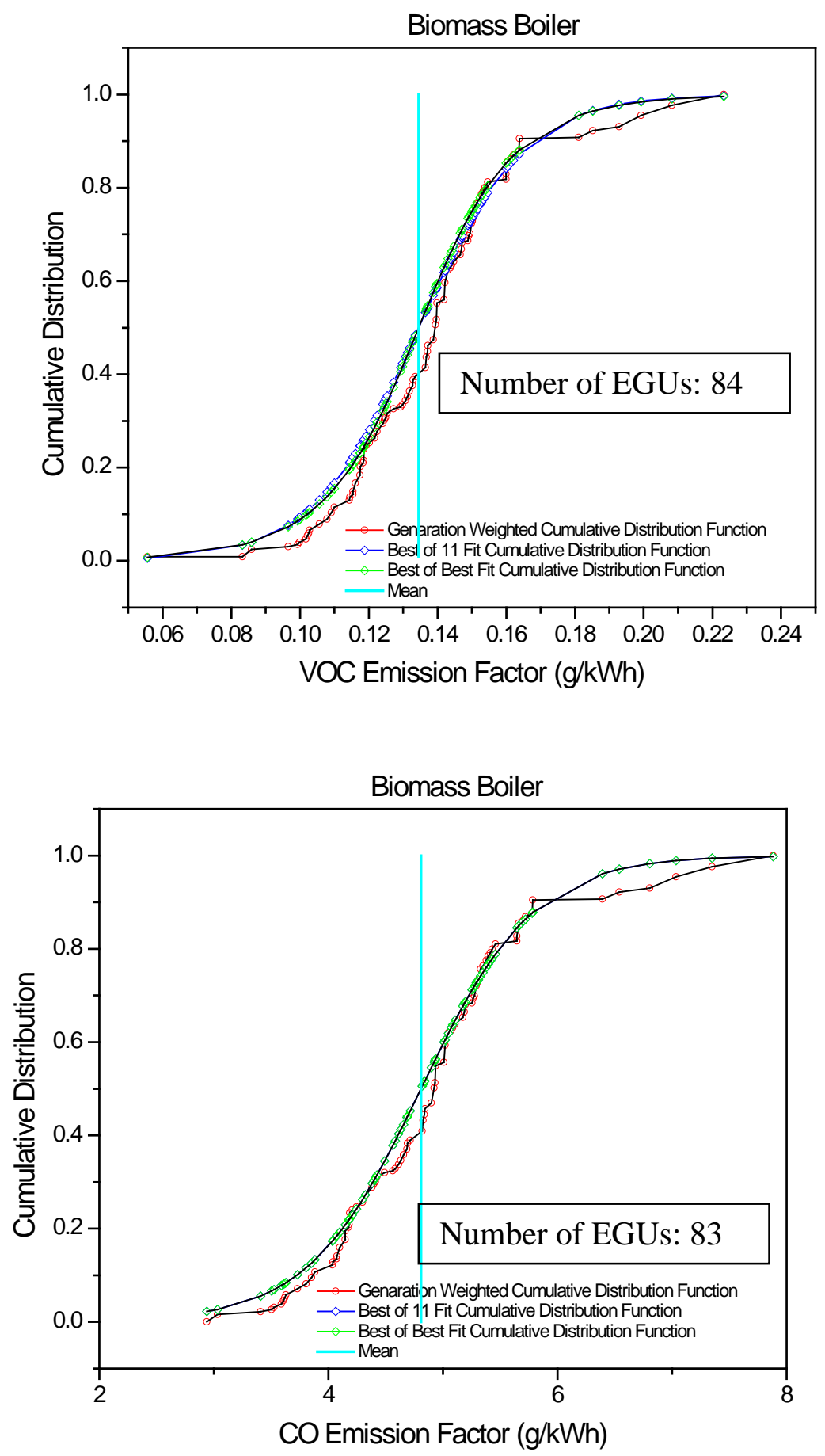

FIGURE A9 Best-fit CDFs of electricity-generation-weighted GHG and CAP emission factors for biomass-fired boilers. 

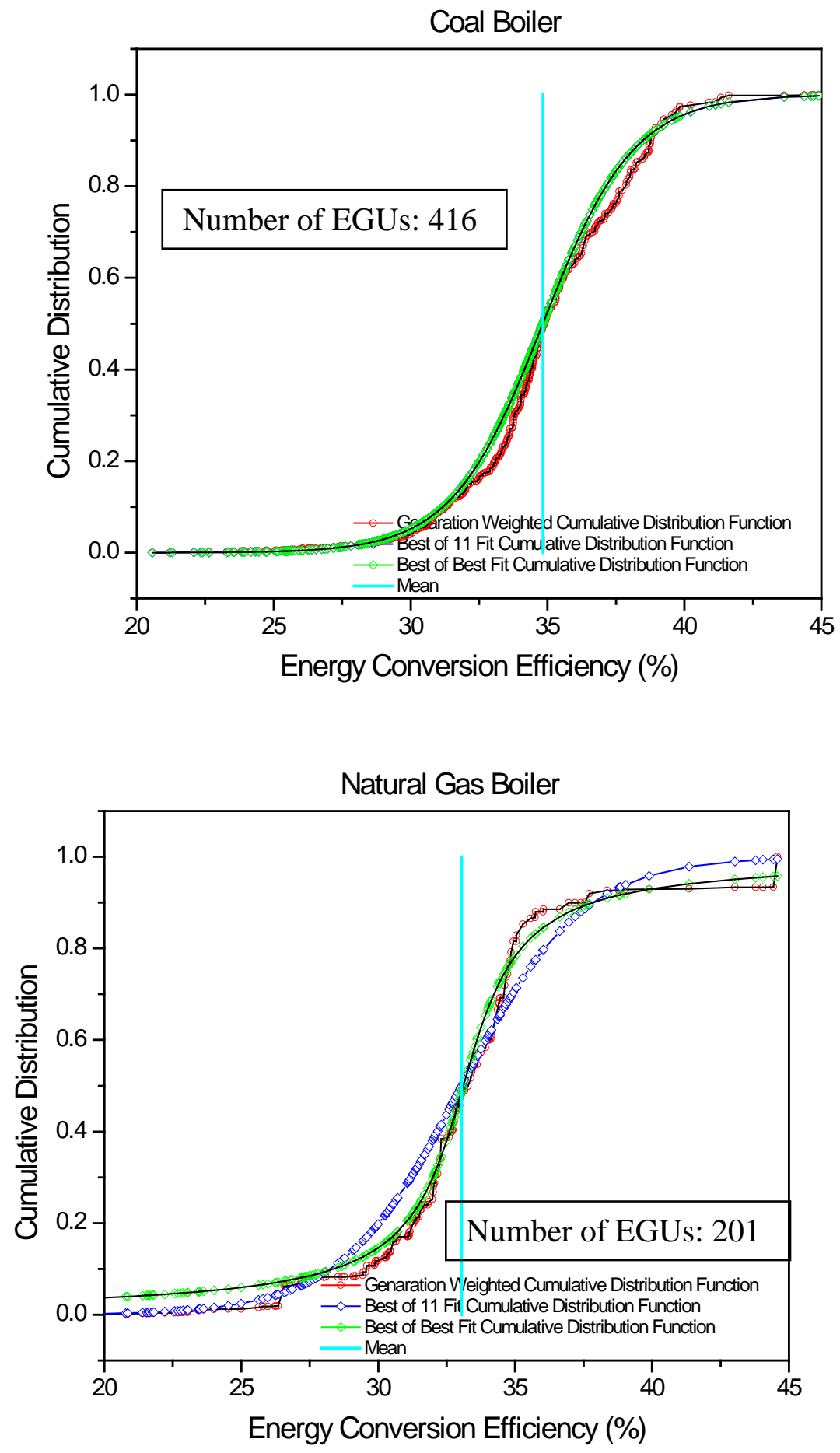

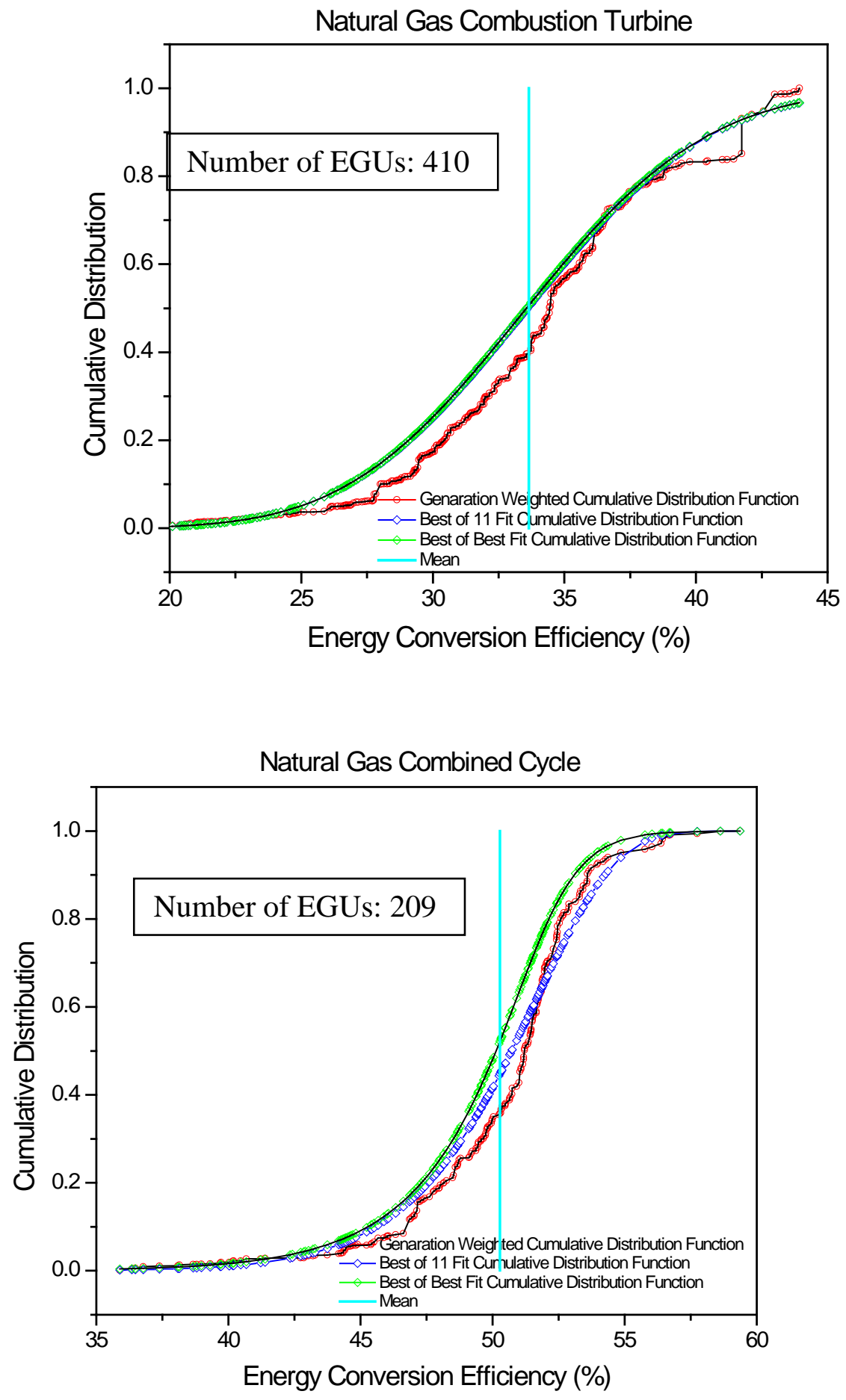

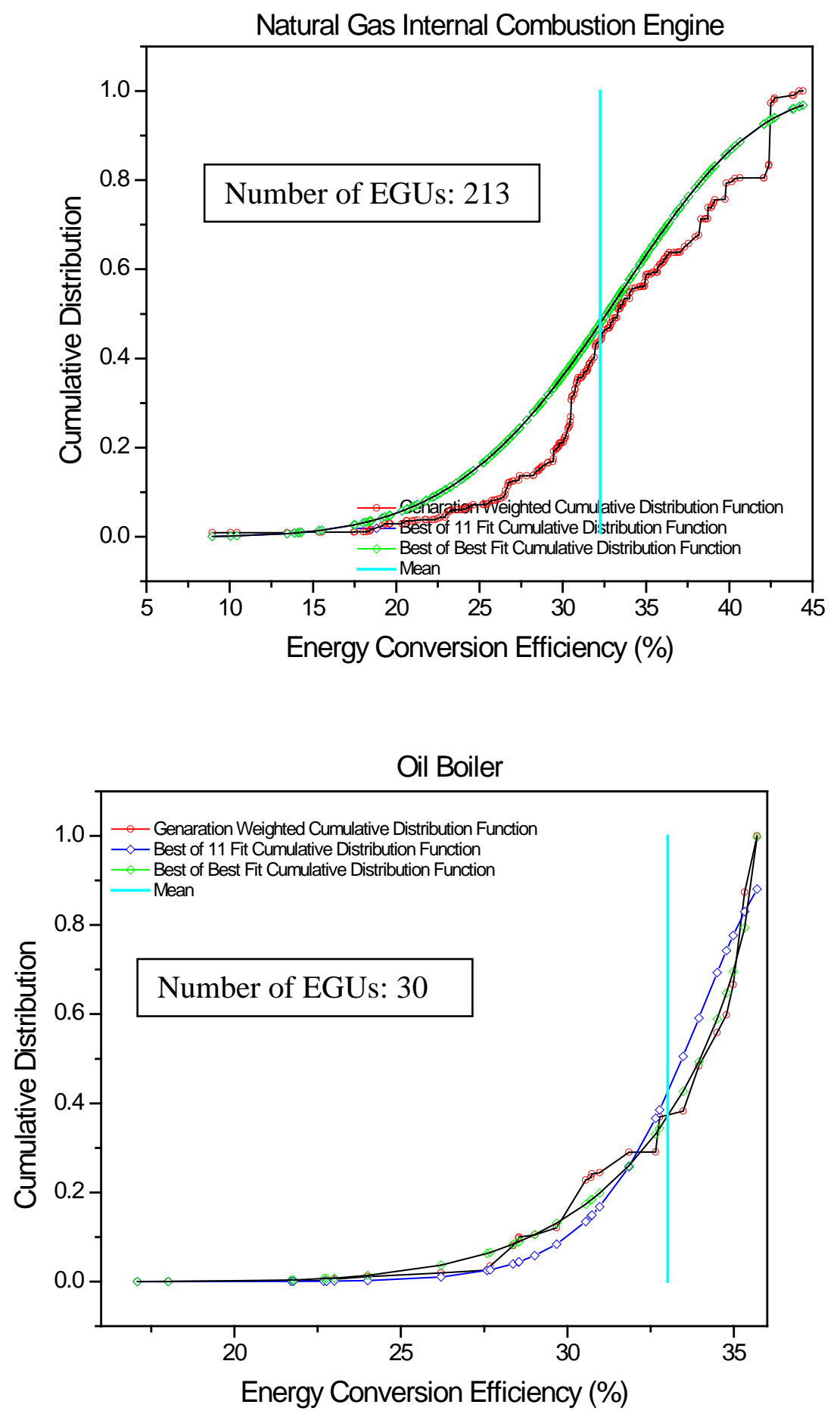

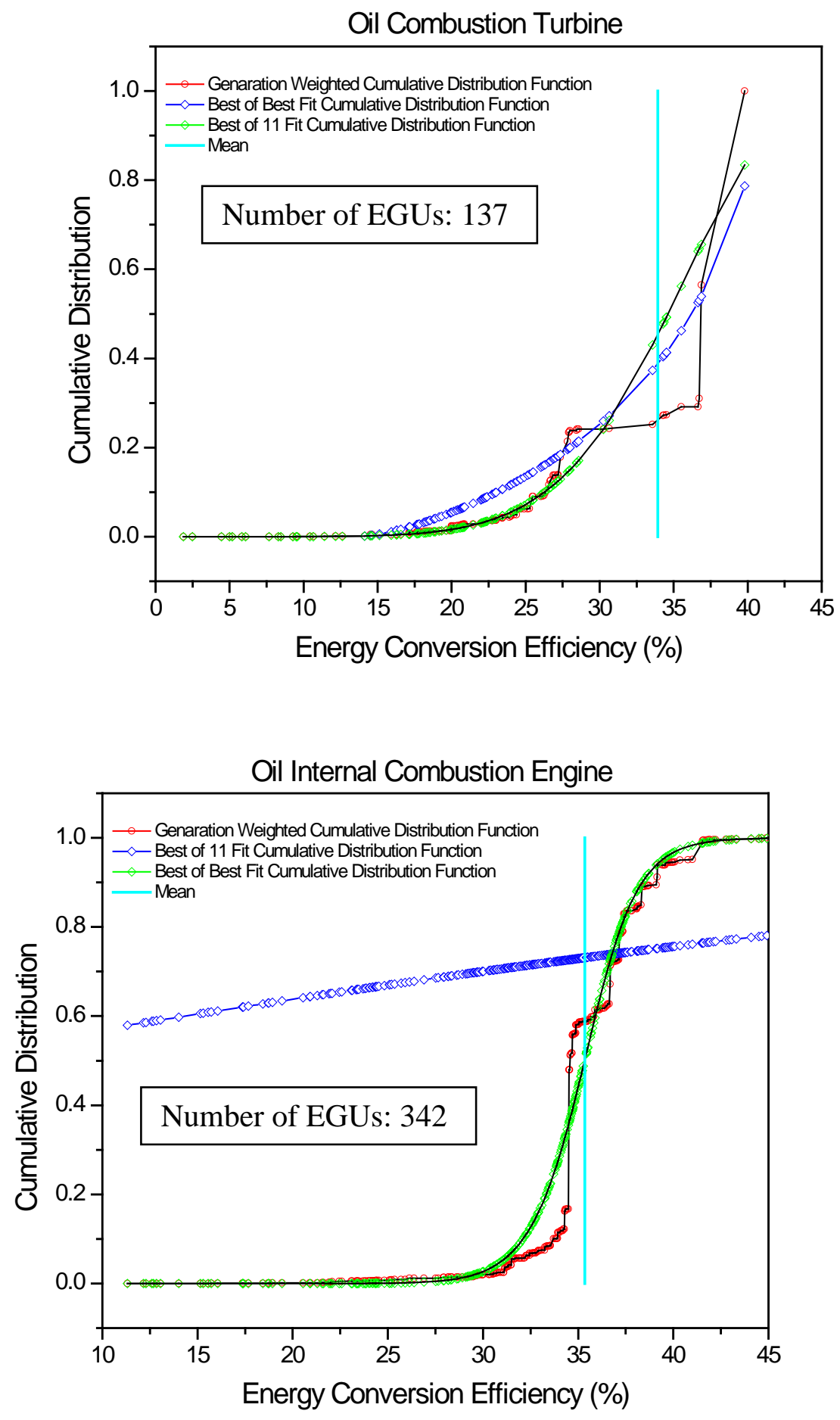


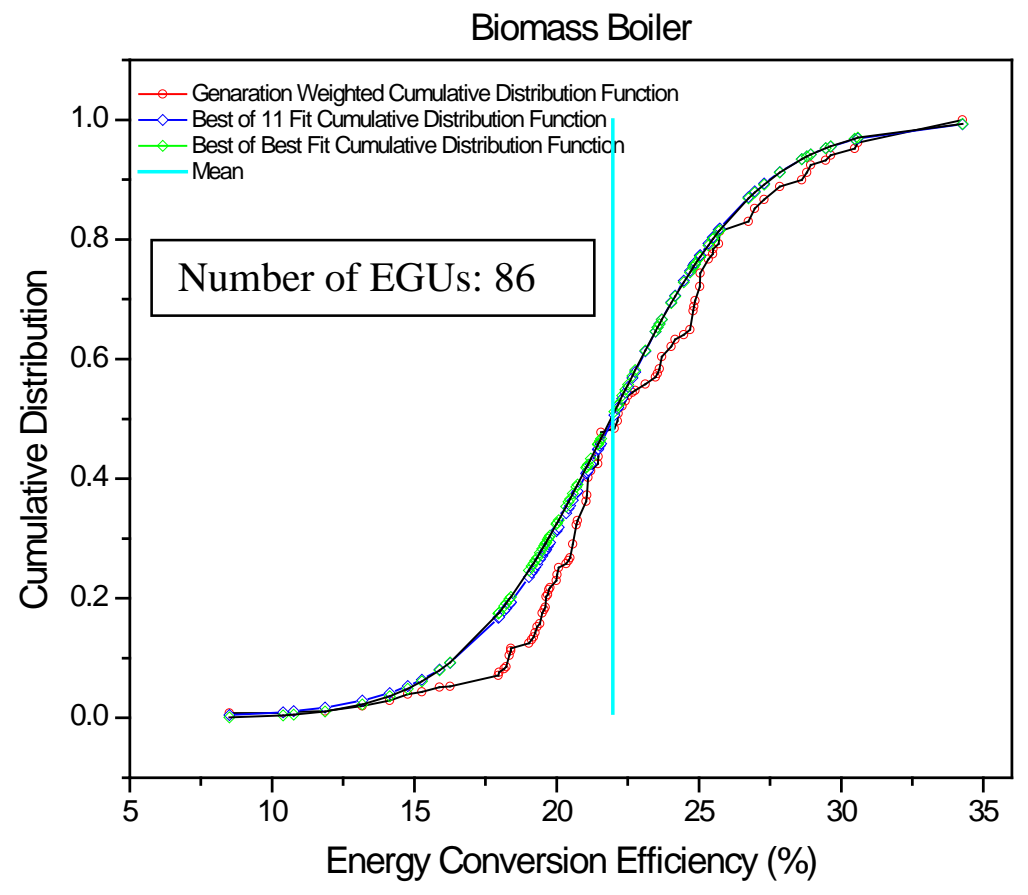

FIGURE A10 Best-fit CDFs of electricity-generation-weighted energy conversion efficiencies for coal-, natural gas-, oil- and biomass-fired boilers, combustion turbines, combined-cycle plants and internal combustion engines. 


\section{Argonne}

\section{Energy Systems Division}

Argonne National Laboratory

9700 South Cass Avenue, Bldg. 362

Argonne, IL 60439-4815

www.anl.gov 